VILNIAUS GEDIMINO TECHNIKOS UNIVERSITETAS

Benas KUNDROTAS

\title{
ŠEŠIAFAZIŲ ASINCHRONINIŲ VARIKLIŲ PEREINAMŲJŲ VYKSMŲ TYRIMAS
}

DAKTARO DISERTACIJA

TECHNOLOGIJOS MOKSLAI,

ELEKTROS IR ELEKTRONIKOS INŽINERIJA (01T)

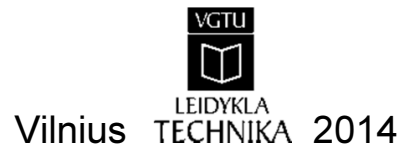


Disertacija rengta 2004-2014 metais Vilniaus Gedimino technikos universitete.

\section{Vadovas}

prof. habil. dr. Roma RINKEVIČIENĖ (Vilniaus Gedimino technikos universitetas, elektros ir elektronikos inžinerija-01T).

Vilniaus Gedimino technikos universiteto Elektros ir elektronikos inžinerijos mokslo krypties disertacijos gynimo taryba:

\section{Pirmininkas}

prof. dr. Jurij NOVICKIJ (Vilniaus Gedimino technikos universitetas, elektros ir elektronikos inžinerija - 01T).

\section{Nariai:}

doc. dr. Eleonora GUSEINOVIENE (Klaipėdos universitetas, elektros ir elektronikos inžinerija - 01T),

prof. habil. dr. Galina MERKURJEVA (Rygos technikos universitetas, informatikos inžinerija - 07T),

prof. dr. Šarūnas PAULIKAS (Vilniaus Gedimino technikos universitetas, elektros ir elektronikos inžinerija - 01T),

prof. habil. dr. Juozapas Arvydas VIRBALIS (Kauno technologijos universitetas, elektros ir elektronikos inžinerija -01T).

Disertacija bus ginama viešame Elektros ir elektronikos inžinerijos mokslo krypties disertacijos gynimo tarybos posėdyje $2014 \mathrm{~m}$. birželio 6 d. 9 val. Vilniaus Gedimino technikos universiteto senato posèdžių salëje.

Adresas: Saulètekio al. 11, LT-10223 Vilnius, Lietuva.

Tel.: (8 5) 274 4956; faksas (8 5) 270 0112; el. paštas doktor@vgtu.It

Pranešimai apie numatomą ginti disertaciją išsiųsti $2014 \mathrm{~m}$. gegužès $5 \mathrm{~d}$.

Disertaciją galima peržiūretti interneto svetaineje http://dspace.vgtu.lt/ ir Vilniaus Gedimino technikos universiteto bibliotekoje (Sauletekio al. 14, LT10223 Vilnius, Lietuva).

VGTU leidyklos TECHNIKA 2250-M mokslo literatūros knyga

ISBN 978-609-457-682-9

(C) VGTU leidykla TECHNIKA, 2014

(C) Benas Kundrotas, 2014

benas.kundrotas@vgtu.lt 
VILNIUS GEDIMINAS TECHNICAL UNIVERSITY

Benas KUNDROTAS

RESEARCH ON TRANSIENT PROCESSES OF SIX PHASE INDUCTION MOTORS

DOCTORAL DISSERTATION

TECHNOLOGICAL SCIENCES,

ELECTRICAL AND ELECTRONIC ENGINEERING (01T) 
Doctoral dissertation was prepared at Vilnius Gediminas Technical University in 2004-2014.

\section{Supervisor}

Prof Dr Habil Roma RINKEVIČIENĖ (Vilnius Gediminas Technical University, Electrical and Electronic Engineering - 01T).

The Dissertation Defense Council of Scientific Field of Electrical and Electronic Engineering of Vilnius Gediminas Technical University:

\section{Chairman}

Prof Dr Jurij NOVICKIJ (Vilnius Gediminas Technical University, Electrical and Electronic Engineering - 01T).

\section{Members:}

Assoc Prof Dr Eleonora GUSEINOVIENĖ (Klaipèda University, Electrical and Electronic Engineering - 01T),

Prof Dr Habil Galina MERKURJEVA (Ryga Technical University, Informatics Engineering - 07T),

Prof Dr Šarūnas PAULIKAS (Vilnius Gediminas Technical University, Electrical and Electronic Engineering - 01T),

Prof Dr Habil Juozapas Arvydas VIRBALIS (Kaunas University of Technology, Electrical and Electronic Engineering - 01T).

The dissertation will be defended at the public meeting of the Dissertation Defense Council of Electrical and Electronic Engineering in the Senate Hall of Vilnius Gediminas Technical University at 9 a. m. on 6 June 2014.

Address: Sauletekio al. 11, LT-10223 Vilnius, Lithuania. Tel.: +370 5274 4956; fax +370 5270 0112; e-mail: doktor@vgtu.lt

A notification on the intend defending of the dissertation was send on 5 May 2014.

A copy of the doctoral dissertation is available for review at the Internet website http://dspace.vgtu.lt/ and at the Library of Vilnius Gediminas Technical University (Sauletekio al. 14, LT-10223 Vilnius, Lithuania). 


\section{Reziumè}

Disertacijoje aprašyti šešiafazių asinchroninių variklių dinaminiai modeliai ir ištirti pereinamieji vyksmai.

Disertaciją sudaro ịvadas, trys pagrindiniai skyriai, išvados, naudotos literatūros ir autoriaus publikacijų disertacijos tema sąrašas.

Ivadiniame skyriuje suformuluota tiriamoji problema, darbo aktualumas, tyrimų objektas, darbo tikslas ir uždaviniai, tyrimų metodika, darbo mokslinis naujumas, rezultatų praktinè reikšmè, ginamieji teiginiai. İvado pabaigoje pristatytos autoriaus paskelbtos publikacijos disertacijos tema ir pateikiamas perskaitytų pranešimų konferencijose sąrašas bei aprašoma disertacijos sandara.

Pirmame skyriuje aprašyti daugiafazių varikliu privalumai lyginant juos su trifaziais ir nurodyti jų taikymo atvejai. Aprašyti šešiafazių asinchroninių varikliu tipai. Pateiktas šešiafazio asinchroninio variklio matematinis modelis. Pristatyti šešiafazių asinchroninių elektros pavarų valdymo metodai. Suformuluotos skyriaus išvados ir disertacijos uždaviniai.

Antrajame skyriuje pateikti šešiafazio asinchroninio variklio kompiuteriniai modeliai sukurti pagal variklio statoriaus, rotoriaus srovių ir srautų išraiškas. Aprašyti imitacinių modeliu naudojimo atvejai greitojo prototipo sistemose. Skyriaus pabaigoje suformuluotos išvados.

Trečiajame skyriuje pristatyti šešiafazių asinchroninių pavarų imitaciniai ir eksperimentiniai tyrimai. Sudarytos sutelktosios dvisluoksnès sutrumpinto žingsnio ir poliaus žingsnio šešiafazių apvijų schemos. Pateikti šešiafazio asinchroninio variklio kompiuterinių modelių, sukurtu pagal variklio statoriaus, rotoriaus srovių ir srautų išraiškas imitacinių tyrimų rezultatai. Aprašytas bandymų stendas. Pateikti eksperimentinio šešiafazès asinchroninès pavaros tyrimo rezultatai. Palyginti imitacinio ir eksperimentinio tyrimų rezultatai.

Disertacijos tema paskelbtos devynios mokslinès publikacijos: penki straipsniai recenzuojamuose mokslo žurnaluose: du - mokslo žurnale, įtrauktame ị Thomson Reuters Web of Science duomenų bazę; vienas - užsienio mokslo žurnale; du - Lietuvos mokslo žurnale; keturi - kituose recenzuojamuose mokslo leidiniuose. Disertacijos tema perskaityti devyni pranešimai tarptautinėse ir Lietuvos mokslinėse konferencijose. 


\section{Abstract}

Dynamic models for investigation transient processes of six phase induction motors are presented in this dissertation.

The thesis layout consists of introduction, three main chapters, conclusions, bibliography and list of publications.

The introduction reveals the investigation problem, importance of the work and the object of research as well as describes the purpose and tasks of the paper, research methodology, scientific novelty, the practical significance of obtained results and defended statements. The author's publications on the subject of the defended dissertation, offering the material of made presentations in conferences and the structure of the dissertation are presented at the end of introduction.

The advantages of multiphase motors over conventional three phase are presented in the first chapter. The applications with multiphase motors are reviewed. The types of six phase induction motors are presented. The mathematical model of six phase induction motor are composed. The control methods of six phase induction motors are reviewed. At the end of the chapter, conclusions and tasks for the dissertation are formulated.

The second chapter is dedicated for methodology to develop two types mathematical models of six phase induction motor. First of them is composed according to stator and rotor current expressions and second one according to stator and rotor flux expressions. Fast prototype systems with simulation models are reviewed. At the end of the chapter, conclusions are formulated.

Simulation and experimental results of six phase induction drive are presented in the third chapter. Two types of six phases motor windings connections are proposed: concentrated double layer short pitch coil winding and concentrated double layer full pitch coil winding. The simulation results of six phase induction motor are analyzed. Experimental stand is proposed and results of six phase induction drive experimental investigation are presented. At the end of the chapter, conclusions according to simulation and experimental results are formulated.

The results of the work were presented in nine scientific publications: two published in journals quoted in Thomson Reuters Web of Science databases, one - in periodic foreign journal, two - in periodic Lithuanian journals, four - in referred international conference materials. Nine reports were presented on the subject in conferences at national and international levels. 


\section{Simboliai ir santrumpos}

\section{Simboliai}
A
- statoriaus A faze;
$A_{1} \quad-$ magnetovaros pirmosios komponentès santykinè amplitude;
$A_{2} \quad-$ magnetovaros antrosios komponentès santykinè amplitude;
a $\quad-$ rotoriaus a faze;
$a-b-c \quad$ fazinè koordinačių sistema;
B $\quad-$ statoriaus B fazé;
b $\quad-$ rotoriaus b faze;
$b_{1, \mathrm{k}} \quad-$ sutelktosios dvisluoksnės sutrumpinto žingsnio apvijos magnetovaros Furje transformacijos koeficientas;
$b_{2, \mathrm{k}} \quad-$ sutelktosios dvisluoksnès poliaus žingsnio apvijos magnetovaros Furje transformacijos koeficientas;
C - statoriaus C fazé;
c $\quad-$ rotoriaus c fazé;
$\cos \varphi \quad-$ variklio galios faktorius;
$d^{e}-q^{e} \quad-$ sinchroniniu greičiu judanti koordinačių sistema;
$d^{s}-q^{s} \quad$ - stacionarioji koordinačių sistema $(\alpha, \beta$ koordinačių sistema);
$f \quad-$ maitinimo tinklo dažnis;
$F_{m} \quad-$ pulsuojamosios magnetovaros amplitudinè verté;
$F_{1} \quad-$ pirmosios statoriaus apvijos pulsuojamoji magnetovara;
$F_{1}(\varphi) \quad-$ dvisluoksnès sutrumpinto žingsnio šešiafazės apvijos pulsuojamoji magnetovara;
$F_{2} \quad-$ antrosios statoriaus apvijos kuriama pulsuojamoji magnetovara;
$F_{2}(\varphi) \quad-$ dvisluoksnès poliaus žingsnio šešiafazès apvijos pulsuojamoji magnetovara;
$F_{3} \quad-$ trečiosios statoriaus apvijos kuriama pulsuojamoji magnetovara;
$F_{4} \quad-$ ketvirtosios statoriaus apvijos kuriama pulsuojamoji magnetovara;
$F_{5} \quad-$ penktosios statoriaus apvijos kuriama pulsuojamoji magnetovara; 


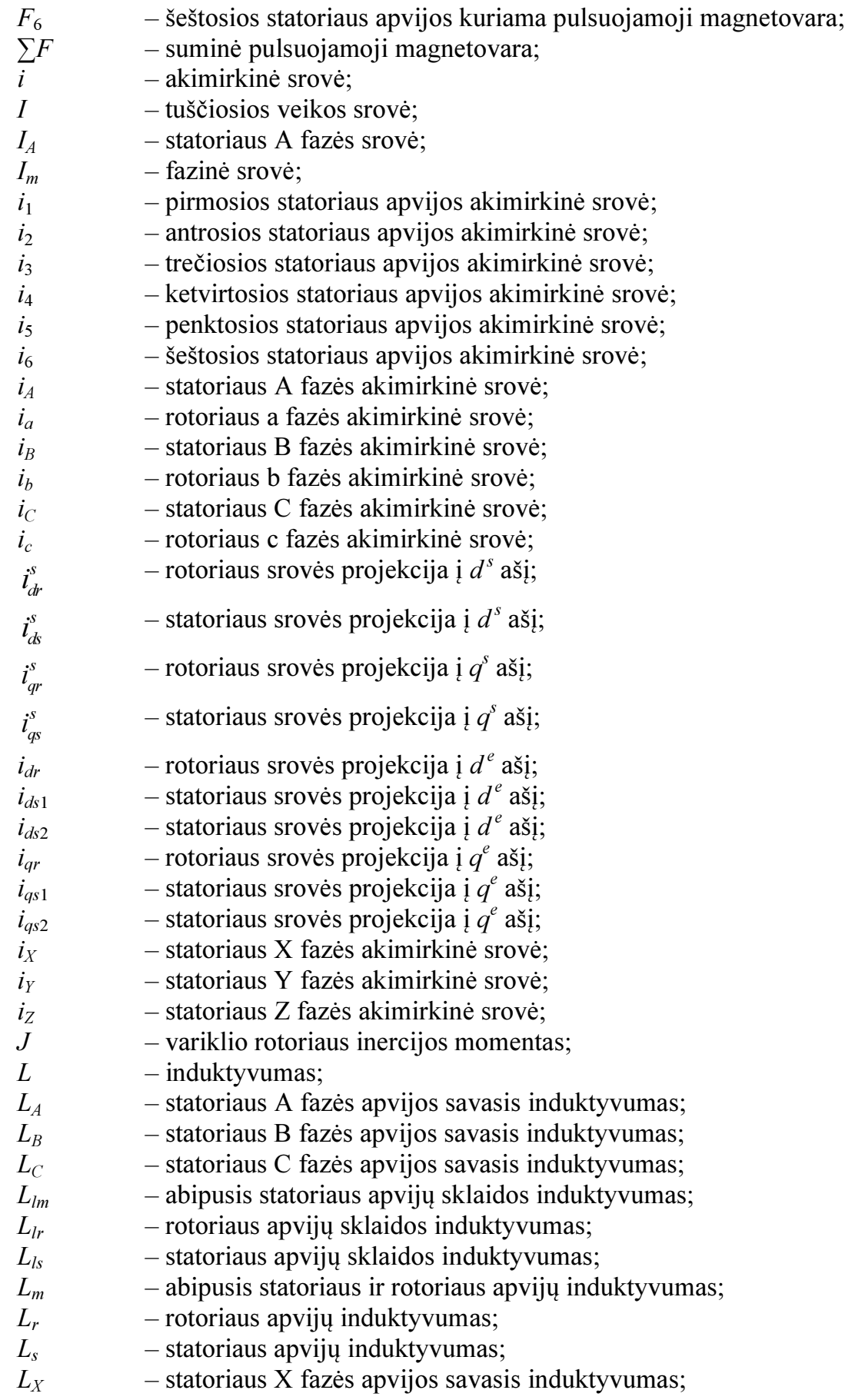

viii 


\begin{tabular}{|c|c|}
\hline$L_{Y}$ & - statoriaus Y fazės apvijos savasis induktyvumas; \\
\hline$L_{Z}$ & - statoriaus Z fazès apvijos savasis induktyvumas; \\
\hline$m$ & - fazių skaičius; \\
\hline$n$ & - variklio rotoriaus apsisukimų skaičius per minutę; \\
\hline$P$ & - variklio polių skaičius; \\
\hline $2 p$ & - variklio polių porų skaičius; \\
\hline$P_{t . v}$ & - tuščiosios veikos galia; \\
\hline$q$ & - variklio poliaus ir fazès griovelių skaičius; \\
\hline$R_{A}$ & - statoriaus A fazinès apvijos varža; \\
\hline$R_{a}$ & - rotoriaus a fazinès apvijos varža; \\
\hline$R_{B}$ & - statoriaus B fazinès apvijos varža; \\
\hline$R_{b}$ & - rotoriaus b fazinès apvijos varža; \\
\hline$R_{C}$ & - statoriaus $\mathrm{C}$ fazinès apvijos varža; \\
\hline$R_{c}$ & - rotoriaus c fazinès apvijos varža; \\
\hline$R_{s}$ & - statoriaus aktyvioji varža; \\
\hline$R_{r}$ & - rotoriaus aktyvioji varža; \\
\hline$R_{X}$ & - statoriaus X fazinès apvijos varža; \\
\hline$R_{Y}$ & - statoriaus Y fazinės apvijos varža; \\
\hline$R_{Z}$ & - statoriaus $\mathrm{C}$ fazinès apvijos varža; \\
\hline$s$ & - Laplaso operatorius; \\
\hline$S$ & - slydimas; \\
\hline$M_{e}$ & - asinchroninio variklio elektromagnetinis momentas \\
\hline$M_{s t}$ & - statinis apkrovos momentas; \\
\hline$U$ & - maitinimo įtampa; \\
\hline$U$ & - akimirkinè įtampa; \\
\hline$u_{A}$ & - statoriaus A fazinės apvijos akimirkinè ịtampa; \\
\hline$u_{a}$ & - rotoriaus a fazinès apvijos akimirkinè įtampa; \\
\hline$u_{B}$ & - statoriaus B fazinès apvijos akimirkinè įtampa; \\
\hline$u_{b}$ & - rotoriaus b fazinès apvijos akimirkinè įtampa; \\
\hline$u_{C}$ & - statoriaus $\mathrm{C}$ fazinès apvijos akimirkinè įtampa; \\
\hline$u_{c}$ & - rotoriaus c fazinès apvijos akimirkinè įtampa; \\
\hline$u_{d r}^{s}$ & - rotoriaus ittampos projekcija i $d^{s}$ aši; \\
\hline$u_{d s 1}^{s}$ & - statoriaus įtampos projekcija į $d^{s}$ ašį; \\
\hline$u_{d s 2}^{s}$ & - statoriaus ịtampos projekcija ị $d^{s}$ ašị; \\
\hline$u_{q r}^{s}$ & - rotoriaus įtampos projekcija $i \underset{q}{ } q^{\mathrm{s}}$ ašį; \\
\hline$u_{q s 1}^{s}$ & - statoriaus įtampos projekcija $i \underset{q}{ } q^{\mathrm{s}}$ ašįi; \\
\hline$u_{q s 2}^{s}$ & - statoriaus įtampos projekcija $i \underset{q}{ } q^{\mathrm{s}}$ ašị; \\
\hline$u_{d r}$ & - rotoriaus ittampos projekcija ị $d^{e}$ ašį; \\
\hline$u_{d s 1}$ & - statoriaus itampos projekcija $\underset{i}{ } d^{e}$ ašị; \\
\hline$u_{d s 2}$ & - statoriaus ittampos projekcija $\underset{i}{ } d^{e}$ ašị; \\
\hline$u_{q r}$ & - rotoriaus įtampos projekcija i $q^{e}$ ašị; \\
\hline$u_{q s 1}$ & - statoriaus ịtampos projekcija i $q^{e}$ ašįi; \\
\hline
\end{tabular}




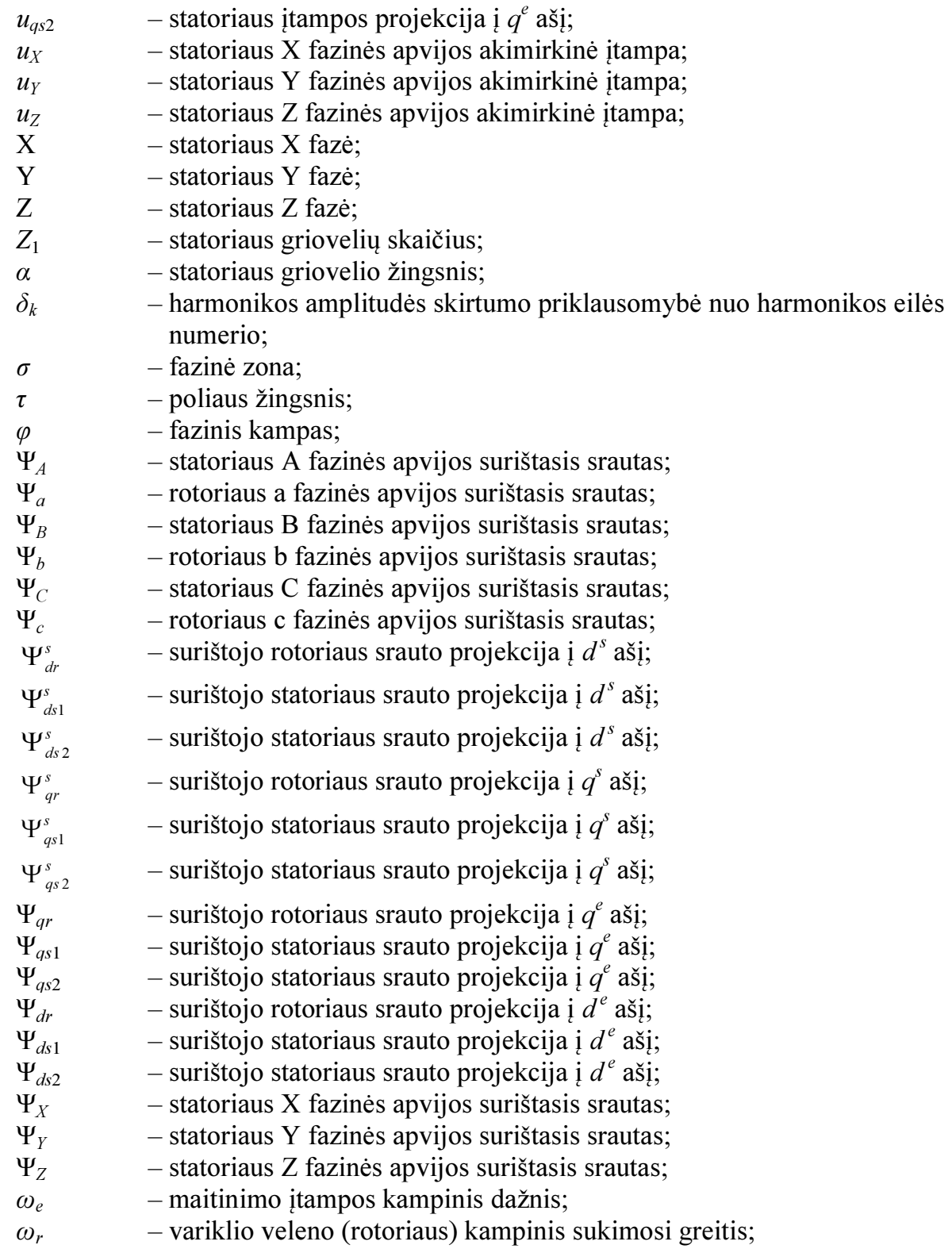




\section{Turinys}

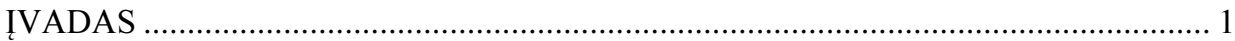

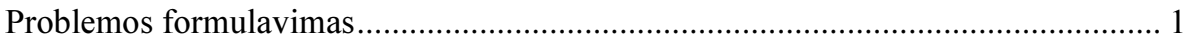

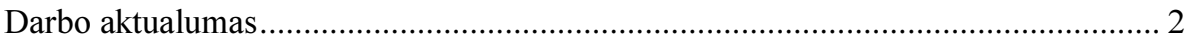

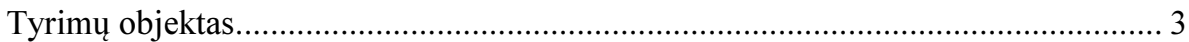

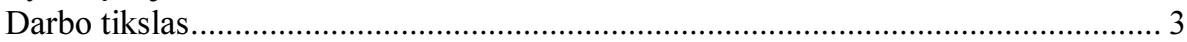

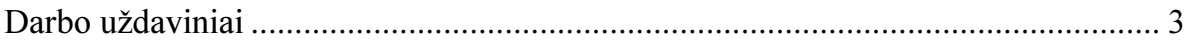

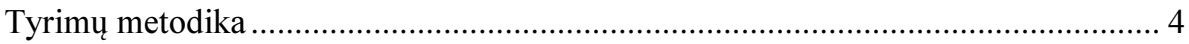

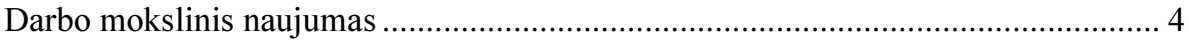

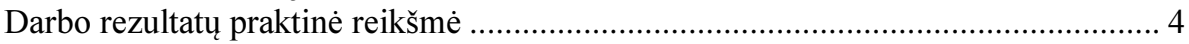

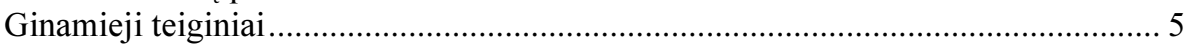

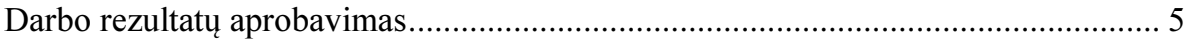

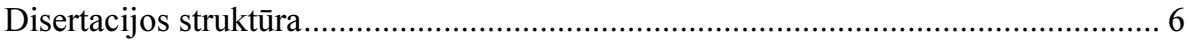

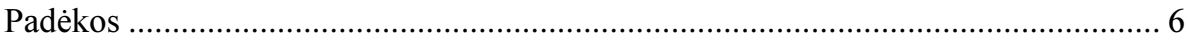

1. ŠEŠIAFAZIỤ ASINCHRONINIŲ VARIKLIŲ IR JŲ VALDYMO APŽVALGA .... 9

1.1. Daugiafaziai asinchroniniai varikliai............................................................ 9

1.2. Asinchroninio variklio koordinačių sistemos ................................................. 12

1.3. Šešiafazio variklio transformavimas i dvifazi ......................................................... 13

1.4. Asinchroninių elektros pavaru valdymo metodai ............................................... 20

1.5. Pirmojo skyriaus išvados ir disertacijos uždavinių formulavimas...................... 27

2. ŠEŠIAFAZIŲ ASINCHRONINIŲ VARIKLIŲ MODELIŲ SUDARYMO

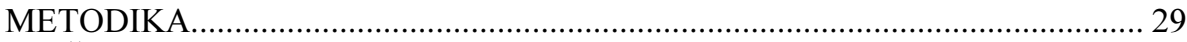

2.1. Šešiafazio asinchroninio variklio modelio sudarymas pagal srovių išraiškas ... 30

2.2. Šešiafazio asinchroninio variklio modelio sudarymas pagal srautų išraiškas.... 43

2.3. Imitacinių modelių naudojimas greitojo prototipo sistemose ............................ 48

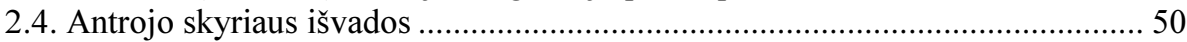




\section{3. ŠEŠIAFAZIO ASINCHRONINIO VARIKLIO IMITACINIAI IR}

EKSPERIMENTINIAI TYRIMAI.

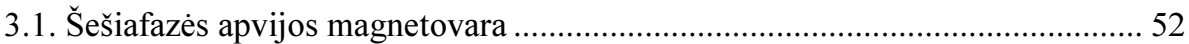

3.2. Sutelktosios dvisluoksnès statoriaus šešiafazès apvijos ................................... 56

3.3. Šešiafazio asinchroninio variklio imitaciniai tyrimai ........................................ 70

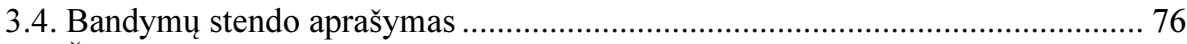

3.5. Šešiafazio asinchroninio variklio eksperimentinis tyrimas ................................ 79

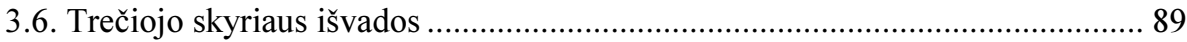

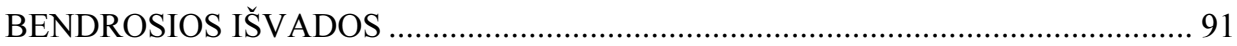

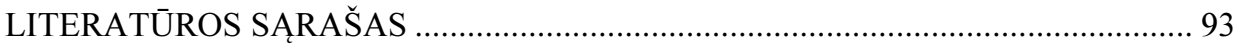

AUTORIAUS MOKSLINIŲ PUBLIKACIJŲ DISERTACIJOS TEMA SĄRAŠAS . 101

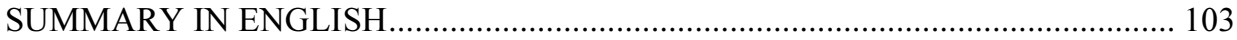

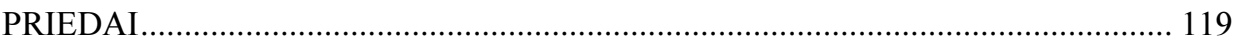

A priedas. Bendraautorių sutikimai teikti publikacijų medžiagą disertacijoje ....... 120

B priedas. Autoriaus mokslinių publikacijų disertacijos tema kopijos.................... 125 


\section{Contents}

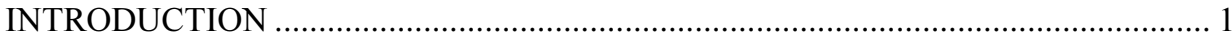

The investigation problem ................................................................................. 1

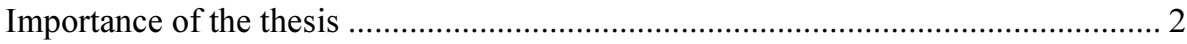

Research object ............................................................................................. 3

Aim of the thesis ........................................................................................... 3

Tasks of the thesis .......................................................................................... 3

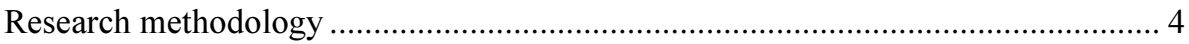

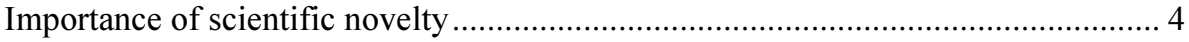

Practical significance of achieved results .......................................................... 4

The defended statements ................................................................................... 5

Aproval of the results .......................................................................................... 5

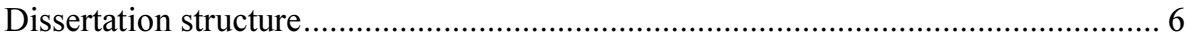

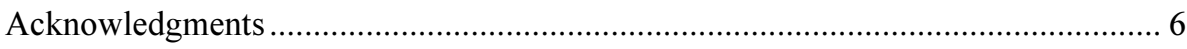

1. REVIEW OF SIX PHASE INDUCTION MOTORS AND CONTROL METHODS. 9

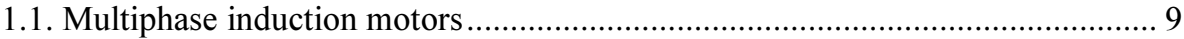

1.2. Cordinate systems of induction motor..................................................... 12

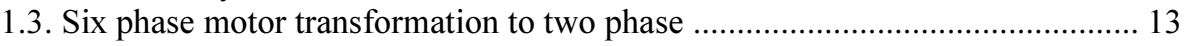

1.4. Control methods of induction motor drives........................................... 20

1.5. Conclusions of the chapter 1 and disertation tasks formulation ...................... 27

2. METHODS TO DEVELOP SIX PHASE MOTOR MODEL …............................... 29

2.1. Six phase induction motor model according to current expressions................. 30

2.2. Six phase induction motor model according to flux expressions .................... 43

2.3. Fast prototype systems with simulation models ........................................ 48

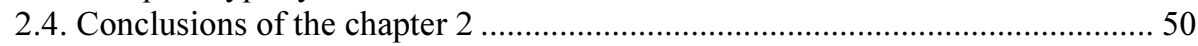

3. SIMULATION AND EXPERIMENTAL RESULTS OF SIX PHASE INDUCTION MOTOR INVESTIGATION ......................................................................... 51 
3.1. Magnetomotive force of six phase winding ....................................................... 52

3.2. Concentrated double layer six phase stator windings ........................................ 56

3.3. Simulation results of six phase induction motor................................................ 70

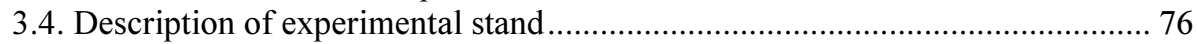

3.5. Experimental investigation of six phase induction motor ................................ 79

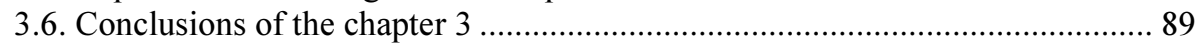

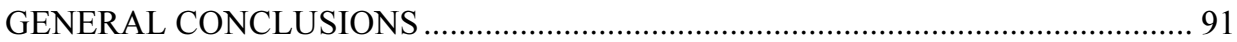

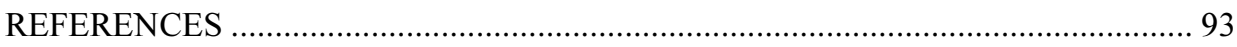

LIST OF THE AUTHOR'S SCIENTIFIC PUBLICATIONS ON THE TOPIC OF

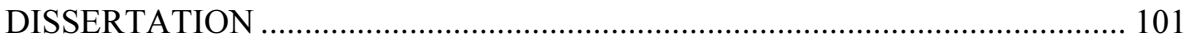

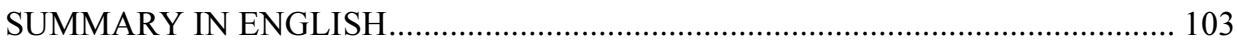

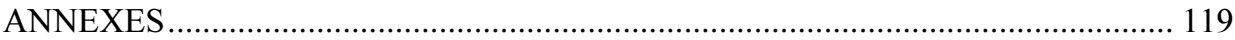

Annex A. The co-authors agreement to present publication ................................. 120

Annex B. Copies of author scientific publications on the subject of dissertation .. 125 


\section{Ivadas}

\section{Problemos formulavimas}

Darbe tirti šešiafaziai asinchroniniai varikliai pasižymi geresnemis savybėmis negu trifaziai varikliai. Tokios pačios vertès jų sukimo momentas gaunamas esant mažesnèm statoriaus srovių vertèms, todèl galia tūrio vienetui yra didesnè negu trifazių asinchroninių variklių. Šešiafazio variklio statoriaus nuostoliai yra mažesni, mažesnès rotoriaus srovių harmonikos ir sukimo momento pulsacijos lyginant su trifaziu. Šešiafazis variklis gali būti paleistas ir dirbti sugedus kelioms statoriaus fazinėms apvijoms. Šie varikliai, lyginant juos su trifaziais varikliais, pasižymi mažesniais akustiniais triukšmais.

Lyginant šešiafazius variklius su didesnio fazių skaičiaus varikliais pastebèta geresnè magnetovaros harmoninè sudètis. Tai lemia mažesnius nuostolius, mažesnes momento pulsacijas ir tylesnị darbą.

Nuo pat trifazių variklių sukūrimo pradètos nagrinèti ir jų valdymo galimybès. Platus trifazių varikliu taikymas valdomose pavarose paskatino sukurti daugybę valdymo metodų. Visų jų principai gali būti taikomi ir šešiafaziams varikliams.

Elektros pavarose, kuriose valdymui naudojami dažnio keitikliai nuolatinė itampa keičiama kintamaja. Tais atvejais, kai elektros pavarose naudojami šešiafaziai varikliai, maitinimui reikalinga šešiafaze kintamoji įtampa. Lokaliose 
sistemose, kuriose viena energijos rūšis keičiama kita, gali būti iš karto generuojamas šešiafazis tinklas.

Šešiafazio variklio dinaminèms charakteristikoms gauti naudojami matematiniai variklių modeliai. Juose matematinių modelių lygtys užrašomos matricu forma ir apskaičiuojamos kompiuteriu. Tačiau šiai dienai yra universalesnis būdas tirti variklių dinamiką - naudoti imitacinius baigtinių elementų modelius. Šie kompiuteriniai modeliai yra naudojami perspektyviose greitojo prototipo sistemose.

Šešiafazių variklių eksperimentinių tyrimų duomenys dažniausiai skelbiami nurodant tik pagrindinius tiriamo variklio parametrus nenurodant statoriaus apvijos tipo. Atsižvelgiant $i$ tai, kad apvijų tipas turi esminès itakos variklio sukimo momentui, galiai, naudingumo ir galios faktoriams bei vibracijoms, yra tikslinga tirti konkrečius atvejus.

\section{Darbo aktualumas}

Daugiafaziai varikliai pirmiausia pradèti taikyti naudojant aukštąsias technologijas karineje ir kosmoso pramonèse. Per pastaruosius du dešimtmečius susidomejjimas šiais varikliais ypatingai suaktyvejjo. Dèl pastebètu privalumų, lyginant juos su trifaziais varikliais, juos imta taikyti laivyboje, naftos pramonejje, lèktuvuose, erdvèlaiviuose, branduolinejje energetikoje. Lemiamą ịtaką intensyvesniam jų tyrimui padarè daugiafazių variklių augantis poreikis automobilių pramoneje. Sie varikliai pradèti taikyti hibridiniuose ir elektra varomuose automobiliuose. Pastebima nuolat auganti tendencija daugiafazius variklius taikyti pramonès įrenginiuose. Inžinieriams yra reikalinga informacija apie sudarytas šių variklių tyrimo metodikas ir detalesni daugiafazių variklių tyrimo duomenys.

Siekiant suprasti ir tinkamai valdyti dinaminių sistemų vyksmus šiuose varikliuose yra naudojamas modeliavimas ir imitavimas. Matematinis modeliavimas yra universalus tyrimo metodas, kuris taikomas iviairiose mokslinèse srityse, taip pat ir mechatronikoje. Kuriant realias mechatronines sistemas pirmiausia jas rekomenduojama modeliuoti ir imituoti. Sistemos imitaciniam tyrimui naudojami programiniai paketai, kurie padeda spręsti inžinerines problemas ir jie dažnai naudojami modelių ir prototipų kūrimui.

Projektuotojas, kurdamas naują sistemą, turi įvertinti ir numatyti visus išorinius poveikius bei trikdžius, kurie darys neigiamą įtaką ir trikdys sistemos darbą. Tačiau ne visada tai ịmanoma padaryti, kol sistema nèra išbandyta darbo aplinkoje. Šiuo atveju sistemos prototipu kūrimas yra priemonè, kuri leidžia realiuoju laiku patikrinti sistemos veikimą, kai dalis sistemos yra jos kompiuterinis modelis. 
Šiame darbe sudarytas šešiafazio asinchroninio variklio kompiuterinis modelis gali būti naudojamas naujų valdymo algoritmų kūrimui, valdymo įrenginių projektavimui ir realių šešiafazių sistemų, kuriose naudojami šie varikliai, tyrimui.

Šešiafazis asinchroninis variklis pasižymi visais daugiafazių variklių privalumais lyginant juos su trifaziais varikliais ir išsiskiria iš visų daugiafazių variklių geresne magnetovaros harmonine sudètimi. Šešiafaziai varikliai gali būti gaminami naudojant trifazių variklių bazę, todèl serijinei jų gamybai yra susiklosčiusios palankios sąlygos.

\section{Tyrimu objektas}

Tyrimų objektas - šešiafazis asinchroninis variklis, jo pereinamieji vyksmai esant įvairioms maitinimo įtampoms bei skirtingoms apkrovoms.

\section{Darbo tikslas}

Šio darbo pagrindinis tikslas - sukurti sutelktosios dvisluoksnès sutrumpinto žingsnio statoriaus apvijos šešiafazị asinchronini variklį, sudaryti šio variklio imitacinį modelį ir ištirti jo pereinamuosius vyksmus.

\section{Darbo uždaviniai}

Darbo tikslui pasiekti keliami tokie uždaviniai:

1. Sudaryti naują sutelktają dvisluoksnę šešiafazę sutrumpinto žingsnio ir sutelktają dvisluoksnę šešiafazę poliaus žingsnio apvijas bei palyginti jų efektyvumą.

2. Sudaryti šešiafazio asinchroninio variklio kompiuterinį modelị pagal srovių išraiškas ir šešiafazio asinchroninio variklio kompiuterinį modelị pagal srautų išraiškas.

3. Sudaryti skaliariniu būdu valdomos šešiafazès asinchroninès pavaros imitacini modeli ir ištirti pereinamuosius vyksmus.

4. Suprojektuoti ir sukonstruoti šešiafazio asinchroninio variklio eksperimentinị tyrimų stendą ir patikrinti sukurtų modelių adekvatumą. 


\section{Tyrimų metodika}

Darbe naudojami analiziniai, skaitmeniniai ir eksperimentinio tyrimo metodai, objektinis kompiuteriniu modeliu sudarymas ir imitacija. Imitaciniai modeliai ${\text { sudaryti } \text { Matlab }^{\circledR} \text { Simulink }}^{\circledR}$ aplinkoje. Eksperimentiniai tyrimai atlikti Vilniaus Gedimino technikos universiteto Elektronikos fakulteto Automatikos katedros laboratorijoje.

\section{Darbo mokslinis naujumas}

Sprendžiant darbo uždavinius gauti šie elektros ir elektronikos inžinerijos mokslui nauji rezultatai:

1. Sudarytos naujos šešiafazių apvijų schemos: sutelktoji dvisluoksnè poliaus žingsnio apvija ir sutelktoji dvisluoksnè sutrumpinto žingsnio apvija. Jų efektyvumas palygintas matematiškai ir didesniu efektyvumu pasižyminti sutelktoji dvisluoksnè šešiafazè apvija išbandyta praktiškai.

2. Sudaryti nauji šešiafazio asinchroninio variklio kompiuteriniai modeliai pagal srovių ir srautų išraiškas, kurie gali būti taikomi kuriant greituosius prototipus.

3. Sukurtas šešiafazès asinchroninès pavaros, valdomos skaliariniu metodu, kompiuterinis modelis, leidžiantis tirti pavaros dinamines charakteristikas.

\section{Darbo rezultatų praktinè reikšmè}

Remiantis tyrimų metodika ir gautais rezultatais gali būti projektuojamos šešiafazès asinchroninès pavaros. Sudarytus kompiuterinius modelius galima lengvai tobulinti ir taikyti ịvairioms inžinerinèms problemoms spręsti. Sukurtos ir imitacijų būdu patikrintos sistemos tinka realiujų sistemų tyrimui.

Šio mokslinio darbo rezultatai yra naudingi projektuojant valdomas šešiafazes asinchronines pavaras. Sudaryti šešiafazio asinchroninio variklio kompiuteriniai modeliai pagal srovių ir srautų išraiškas tinka šešiafazių dažnio keitiklių algoritmų bei veikimo savybių tyrimui.

Disertacijos tema pateiktų darbų aktualumą rodo tai, kad jais remtasi publikuojant Europos socialinio fondo paramos projekto: „Microsensors, microactuators and controllers for Mechatronic systems (Go-Smart)" rezultatus.

Sukonstruotas šešiafazio asinchroninio variklio eksperimentinio tyrimo stendas bus naudojamas tolimesniems Vilniaus Gedimino technikos universiteto 
Automatikos katedroje vykdomiems šešiafazio asinchroninio variklio tyrimams, kuriais siekiama ištirti dinaminius procesus esant skirtingoms apkrovų vertèms.

\section{Ginamieji teiginiai}

1. Sudarytos naujosios sutelktosios dvisluoksnès sutrumpinto žingsnio šešiafazès apvijos magnetovaros pirmoji harmonika yra $22 \%$ didesnè negu sutelktosios dvisluoksnès poliaus žingsnio šešiafazès apvijos.

2. Sudarytas Matlab $^{\circledR}$ Simulink $^{\circledR}$ šešiafazio asinchroninio variklio modelis dinaminiams vyksmams tirti leidžia gauti momento ir greičio pereinamųu vyksmų charakteristikas, esant skirtingoms maitinimo itampoms, dažniams ir apkrovoms.

3. Atliktas sukurto ir pagaminto sutelktosios dvisluoksnès sutrumpinto žingsnio apvijos šešiafazio asinchroninio variklio eksperimentinis ir imitacinis pereinamujų vyksmų tyrimas rodo, kad nusistovejjusios sukimo momento ir greičio eksperimentinès ir apskaičiuotos vertès skiriasi mažiau kaip $4 \%$.

\section{Darbo rezultatų aprobavimas}

Tyrimai atlikti Vilniaus Gedimino technikos universiteto Automatikos katedroje. Disertacijos tema atspausdintos devynios mokslinès publikacijos. Penkios periodiniuose recenzuojamuose mokslo žurnaluose: dvi - mokslo žurnale, įtrauktame i Thomson Reuters Web of Science duomenų bazę; viena - užsienio mokslo žurnale, dvi - Lietuvos mokslo žurnale; keturios - kituose recenzuojamose mokslo leidiniuose.

Disertacijoje atliktų tyrimų rezultatai pristatyti devyniose mokslinėse konferencijose Lietuvoje ir užsienyje:

- Lietuvos jaunuju mokslininkų konferencijose Mokslas - Lietuvos ateitis 2011, 2012, 2013 m., ivykusiose Vilniuje.

- Tarptautineje konferencijoje Elektros ir valdymo technologijos 2011 m., ivykusioje Kaune.

- Tarptautineje konferencijoje Elektronika 2011 m., ivykusioje Kaune.

- Tarptautinèse konferencijose Mechatronic Systems and Materials 2011, 2013 m., ivykusiose atitinkamai Kaune ir Vilniuje.

- Tarptautineje konferencijoje Electrical, computer, electronics, communication engineering 2013 m., ivvykusioje Ciuriche, Šveicarijoje. 
- Tarptautineje konferencijoje Doctoral school of energy and geotechnology II 2013 m., ivykusioje Parnu mieste, Estijoje.

Autoriaus darbais remtasi Europos socialinio fondo paramos projekte: „Microsensors, microactuators and controllers for Mechatronic systems (GoSmart)", reg. Nr. VP1-2.2-SMM-08-K-01-015.

$2013 \mathrm{~m}$. autorius stažavosi Vestfold universitete koledže, Norvegijoje, Fizinių ir technologijos mokslų centre, Lietuvoje ir Talino technikos universitete, Estijoje.

\section{Disertacijos struktūra}

Disertaciją sudaro ịvadas, trys skyriai, rezultatų apibendrinimas, literatūros ir publikacijų disertacijos tema sąrašas.

Disertacijoje yra 118 puslapių teksto, 99 paveikslai, 3 lentelès ir 43 numeruotos formulès. Rašant disertaciją remtasi 104 literatūros šaltiniais. Pirmame disertacijos skyriuje apžvelgiami šešiafazių asinchroninių variklių tipai, šių variklių matematiniai modeliai ir šešiafazių asinchroninių pavarų valdymo metodai. Antrame skyriuje aprašomi šešiafazių asinchroninių pavarų tyrimo metodai. Trečiajame skyriuje pateikiami šešiafazių asinchroninių pavarų imitacinių ir eksperimentinių tyrimų rezultatai.

\section{Padėkos}

Iš visos širdies dèkoju darbo vadovei prof. habil. dr. Romai Rinkevičienei už mokymą ir vadovavimą rašant straipsnius ir rengiant disertaciją.

Nuoširdžiai dẻkoju prof. em. habil. dr. Algirdui Smilgevičiui už indèlį $\mathfrak{i}$ mokslinius tyrimus, išsakytus vertingus patarimus, bei pareikštas pastabas.

Dėkoju prof. Algirdui Sužiedėliui už vadovavimą mokslinei stažuotei Fizinių ir technologijos mokslų centro Puslaidininkių fizikos institute.

Didelis ačiū dr. Agnei Johannessen ir prof. Erik Johannessen už pagalbą organizuojant mokslinę stažuotę.

Dékoju doc. dr. Sauliui Lisauskui ir doc. dr. Andriui Petrovui už bendrai atliktus disertacijos tema mokslinius darbus.

Už supratingumą ir begalinę kantrybę širdingai dèkoju sutuoktinei Gretai.

Dékoju tečciui prof. habil. dr. Algiui Jurgiui Kundrotui už vertingas pastabas ir mamai Bronislavai Kundrotienei už moralini palaikymą.

Nuoširdus ačiū prof. habil. dr. Algimantui Juozui Poškai už paskatinimą vykdyti mokslinę veiklą. 
Dékoju Krašto apsaugos ministerijai už sudarytas sąlygas studijuoti Vilniaus Gedimino technikos universiteto doktorantūroje. 



\section{1}

\section{Šešiafazių asinchroninių variklių ir ju valdymo apžvalga}

Skyriuje apžvelgiami daugiafaziai asinchroniniai varikliai ir jų taikymo atvejai. Pateikiami šešiafazių asinchroninių variklių tipai. Aprašomos asinchroninio variklio koordinačių sistemos. Pateikiamas šešiafazio asinchroninio variklio transformavimas i dvifazi modelis. Aprašomi asinchroninių variklių valdymo principai. Skyriaus pabaigoje pateikiamos pirmojo skyriaus išvados ir tikslinami darbo uždaviniai.

\subsection{Daugiafaziai asinchroniniai varikliai}

Pramoneje dèl techninių ir ekonominių pranašumu labiausiai paplitę trifaziai kintamosios srovès asinchroniniai varikliai. Šie varikliai maitinami iš trifazès itampos tinklo ir juose kuriamas sukamasis apskritiminis magnetinis laukas. Trifaziai asinchroniniai varikliai pasižymi nesudetinga konstrukcija, paprasta eksploatacija ir patikimumu.

Mokslinèje literatūroje trifazę srovių sistemą naudojantys daugiafaziai varikliai yra apibrěžiami kaip trifaziai, o daugiafaziais ịvardijami varikliai, kurių fazių skaičius didesnis už tris. Disertacijoje bus naudojama ta pati praktika ir 
daugiafaziais bus apibrèžiami keturfaziai, penkiafaziai, šešiafaziai ir t.t. varikliai.

Daugiafaziai varikliai pradèti tirti apie 1960 metus, kai kintamosios srovès pavaros buvo maitinamos naudojant mažo dažnio inverterius (Levi, 2008). Pastebèta, kad žemas dažnis sukelia dideles momento pulsacijas ir prieita išvados, kad geriausia šiai problemai spręsti yra didinti variklio fazių skaičių.

Tolimesni daugiafazių variklių vystymąsi sąlygojo ir kiti atrasti jų privalumai: atsparumas gedimams ir didesnis daugiafazių variklių momentas, lyginant su trifaziais varikliais, esant mažesnei fazinei srovei. Pastarasis privalumas ir šiai dienai yra vienas pagrindinių lemiantis daugiafazių variklių taikymą pramoneje.

Nuolatinès srovès daugiafazių (žingsninių) variklių vystymąsi paskatino skaičiavimo mašinų atsiradimas. Pradejus naudoti daugiafazius variklius skaičiavimo įrenginiuose buvo pasiektas didesnis įrenginių valdymo tikslumas.

Vis dažniau naudojant daugiafazius kintamosios srovės variklius pavarose atrasta ir daugiau jų privalumų. 1990 metais ypatingai suaktyvejo daugiafazių varikliu tyrimas pradejus juos taikyti laivuose. Tyrimais nustatyta, kad daugiafazių variklių statoriaus nuostoliai mažesni, mažesnès rotoriaus srovių harmonikos, mažesnès momento pulsacijos. Daugiafaziai varikliai gali dirbti dingus statoriaus fazei. Jie pasižymi mažesniais akustiniai triukšmais lyginant juos su trifaziais varikliais (Gregor, et al., 2008; Williamson, et al., 2003). Šiu varikliu privalumai paskatino juos naudoti ne tik laivuose (Abbas, et al., 1984, Pavithran, et al., 1988; Andrese, et al., 1981; Gopakumar, et al., 1984; Gritter, et al., 2005; Lu, et al., 2005; Corzine, et al., 1998; Smith, et al., 2003; Williamson, et al., 2004) bet ir elektrinèse arba elektrinèse - hibridinèse transporto priemonèse, orlaivių konceptiniuose modeliuose, lokomotyvuose (Monti, et al., 1995; Steiner, et al., 2000; Mantero, et al., 1999; Mantero, et al., 2000; Abolhassani, 2005), vandens aparatuose, erdvèlaiviuose robotams valdyti ir didelès galios įrenginiuose (Apsley, et al., 2009; Miranda, et al., 2009; Rata, et al., 2007; Zdenek, 1986; McSharry, et al., 1998; Simond, et al., 2005).

Vienas didžiausių daugiafazių pavarų diegimo sunkumų yra tai, kad pramoneje naudojamas trifazis tinklas ir daugiafazio asinchroninio variklio maitinimui yra reikalingas inverteris. Papildomas pavaros elementas brangina sistemos kainą, tačiau srityse, kur pirmaeilis sistemos vertinimo kriterijus yra patikimumas, išaugusi sistemos kaina yra vertinama kaip atsiperkanti investicija. Trifazio asinchroninio variklio trūkumai: pasileisti sugedus vienai iš statoriaus fazinių apvijų ir rotoriui suktis sugedus kelioms statoriaus fazinèm apvijoms tokiu atveju yra esminiai. Daugiafaziai varikliai išvengia šių problemų (Jacobina, et al., 2005; Fu, et al., 1994; Jahns, 1980; Merabtene, et al., 2003; Singh, et al., 2000; Golubev, et al., 2001; Apsley, et al., 2001; Jacobina, et al., 
2004; Zheng, et al., 2006; Jacobina, et al., 2004; Parsa, et al., 2004; Locment, et al., 2006).

Branduolinejje energetikoje arba atomineje laivyboje pirminès energijos šaltinis yra branduolinè reakcija. Generatorius šiose sistemose mechaninę veleno energiją verčia pageidaujamo fazių skaičiaus elektros energija. Tokiu atveju branduoliniuose objektuose gali būti kuriamas daugiafazis elektros tinklas ir avariniuose įrenginiuose, kur reikalingas didelis įrenginių patikimumas, saugu darbą gali užtikrinti daugiafaziai varikliai.

Elektros pavarų patikimumas yra ypatingai svarbus erdvėlaiviuose. Be jau paminètų dèkingų sąlygų naudoti daugiafazius variklius jų panaudojimą sąlygoja ir mažesni remonto kaštai, kurie kosmose yra daug kartų didesni negu ịprastomis sąlygomis. Daugiafaziai varikliai dèl patikimumo naudojami ir palydovų ịrenginiuose, kurie dèl milžiniškų atstumų yra vienakrypčiai.

Atominèje laivyboje galimybė generuoti norimo fazių skaičiaus elektros tinklą yra išnaudojama didesnei variklio galiai gauti. Šių laivų sraigtui sukti šiai dienai naudojami daugiafaziai elektros varikliai.

Privalumas gauti didelę galią esant santykinai mažoms srovėms buvo ivertintas ir orlaivių konstruktorių. Daugiafaziai varikliai buvo pritaikyti komercinių lèktuvų parkavimui oro uostuose. Toks sprendimas leido konstruktoriams intensyvų reaktyvinių variklių naudojimą pakeisti elektros varikliais ir tokiu būdu pasiekti gerų ekologinių rezultatų: sumažinti reaktyvinio kuro suvartojimą ir prislopinti variklių triukšmingumą didelès žmonių koncentracijos zonose.

Laboratorijose tiriami ir moksliniuose straipsniuose publikuojami penkiafazių (Lu, et al., 2005; Iqbal, et al., 2010; Iqbal, et al., 2010; Casadei, et al., 2008; Duran, et al., 2008), šešiafazių (Miranda, et al., 2009; Gregor, et al., 2008; Kadaba, et al., 2011), devynfazių (Kats, 1997), dvylikafazių (Williamson, et al., 2003), penkiolikafazių (Weichao, 2008), aštuoniolikafazių (Grigore Muler, 2010) variklių tyrimo rezultatai. Šių tyrimų iniciatoriai dažniausiai yra karo, automobilių arba kosmoso pramonès atstovai.

Moksliniuose straipsniuose yra nurodoma, kad šešiafaziai varikliai pasižymi visais aukščiau išdèstytais daugiafazio variklio privalumais. Papildomai yra nurodoma, kad lyginant su didesnio fazių skaičiaus varikliais šešiafazių variklių magnetovaros harmoninè sudètis yra geresnè (Kats, 1997). Tai lemia mažesnius nuostolius, mažesnes momento pulsacijas ir tylesnị darbą. Gaunamos geresnès charakteristikos, mažesnès medžiagų sąnaudos ir kaina.

Pavieniais atvejais šešiafaziai varikliai dèl akivaizdžiai geresnių savybių pakeičia pramonès įrenginiuose trifazius variklius. Jų taikymą riboja nepakankami šešiafazio asinchroninio variklio charakteristikų tyrimai. 


\subsection{Asinchroninio variklio koordinačių sistemos}

Skaičiavimo mašinų ir vèliau kompiuterių atsiradimas sudare palankias sąlygas vystytis matematiniam sistemų modeliavimui. Pirmiausia šį tyrimo būdą pradejo taikyti aukštujų technologijų kūrimui kosmoso ir karinè pramonès. Vèliau matematinis sistemų modeliavimas buvo perkeltas į žemesniujų technologijų sritis.

Elektros mašinų teorijoje matematinis modeliavimas yra taikomas nuodugniam variklio veikimo tyrimui. Matematinį variklio modeli sudaro lygtys, kurios apibūdina ryši tarp variklio kuriamo elektromagnetinio momento ir pagrindinių elektrinių bei mechaninių dydžių.

Asinchroninių variklių tyrimas remiasi paskirstytujų ir sutelktujų parametrų matematiniais modeliais. Paskirstytujų parametrų modelio pagrindas yra atskiru variklio dalių kuriamų magnetinių laukų nagrinejjimas. Didžiausias šio modelio privalumas yra didelis bendrumas ir tikslumas. Jo trūkumais įvardijama: ilgas skaičiavimo laikas, kuris riboja šių modelių naudojimą realiuoju laiku valdomose sistemose ir nepakankamas temperatūros ir medžiagų savybių įtakos ivertinimas.

Sutelktujų parametrų matematiniai modeliai dažniausiai naudojami elektros mašinų tyrimui. Matematinių lygčių parametrai yra varžos ir induktyvumai, kurie naudojami magnetiniams srautams, elektromagnetiniams momentams ir kitiems dydžiams išreikšti.

Sutelktuju parametrų asinchroninio variklio modeliai pateikti 1.1 paveiksle. Jie sudaryti naudojant keletą skirtingų metodų, tačiau du iš jų populiariausi: tai fazinių koordinačių modelis ir ekvivalentinès dvifazès mašinos $d-q$ koordinačių sistemos modelis (Ahmad, 2010; Bose, 2006; Chiasson, 2005; Krause, et al., 2002; Marino, et al., 2010; Ong, 1998; Sul, 2011; Wach, 2011; Kriaučiūnas, 2013).

Fazinių koordinačių modelio matematinèse išraiškose abipusis statoriaus ir rotoriaus induktyvumas bei kiti kintantys parametrai įvertinami atsižvelgiant $\mathfrak{i}$ rotoriaus padètį. Variklio rotoriui sukantis, kinta abipusis statoriaus ir rotoriaus induktyvumas, todèl matematinio modelio lygtys yra netiesinès, parametrai kinta harmoniniu dèsniu.

Siekiant supaprastinti variklio dinaminių vyksmu matematini modeli, taikomi transformuotų koordinačių modeliai. Śiuose modeliuose panaikinama apvijų induktyvumų ir abipusių induktyvumu priklausomybe nuo sukiojo variklio rotoriaus posūkio kampo arba tiesiaeigio variklio antrinio elemento poslinkio. Atsiranda galimybè operuoti ne sinuso desniu kintančiais kintamaisiais, bet jų amplitudemis. Koordinačių transformacija palengvina dinaminių procesų nagrinèjimą (Rinkevičienè, Petrovas, 2008). 
Asinchroninio variklio koordinačių sistemų transformacijas nagrinèjo mokslininkai: R. H. Parkas, H. C. Stanley, H. Kronas, D. S. Beretonas. R. H. Parkas transformavo variklio statoriaus kintamuosius ì sinchroniniu greičiu besisukančią koordinačių sistemą susietą, su variklio rotoriumi. Jis ịrodé, kad laike kintantys induktyvumai bei atsiradę dèl apvijų judẻjimo viena kitos atžvilgiu ir elektrinès grandinès su kintamomis induktyviosiomis varžomis gali būti eliminuoti (Grigore - Muler, 2010; Boldea, Tutelea, 2010).

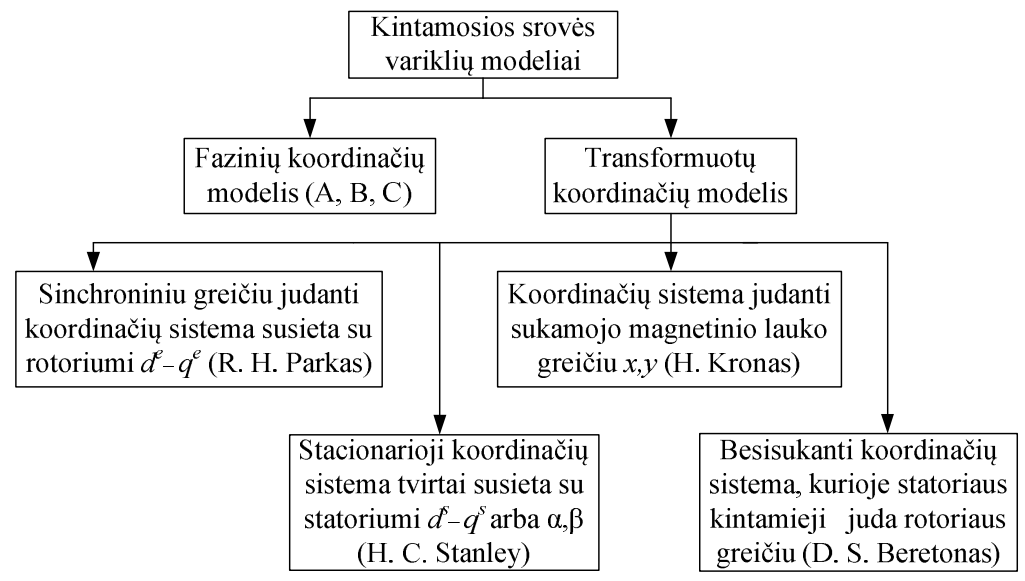

1.1. pav. Asinchroninių variklių modeliai

Fig.1.1. Models of induction motors

H. C. Stanley koordinačių sistemą susiejo su statoriumi. Jis įrodé, kad laike kintantys induktyvumai, atsiradę dèl apvijų judejjimo, gali būti eliminuoti transformuojant rotoriaus kintamuosius i kintamuosius, susietus su fiktyviomis statoriaus apvijomis. Mokslineje literatūroje H. C. Stanley koordinačių sistema dažnai vadinama $\alpha, \beta$.

H. Kronas statoriaus ir rotoriaus kintamuosius transformavo į koordinačiu sistemą, kuri juda sukamojo magnetinio lauko greičiu. D. S. Beretonas pasiūlè dar vieną transformaciją - variklio statoriaus kintamuosius transformuoti i besisukančią koordinačių sistemą, kuri tvirtai susieta su rotoriumi (Rinkevičienè, Petrovas, 2008; Janickas, 2013).

\section{3. Šešiafazio variklio transformavimas ị dvifazị}

Šešiafaziai asinchroniniai varikliai atsižvelgiant $\mathfrak{i}$ statoriaus apvijas gali būti dviejų rūšių: perstumtų statoriaus fazinių apvijų ir tipinès konstrukcijos. 
Perstumtų statoriaus fazinių apvijų šešiafazio variklio statorius pateiktas 1.2 paveikslo a) atvejis. Jis gaunamas naudojant trifazi asinchronini variklį, kurio kiekviena iš trijų statoriaus fazinių apvijų yra padalinama i dvi dalis taip, kad tarp jų ašių susidarytų kampinis poslinkis.

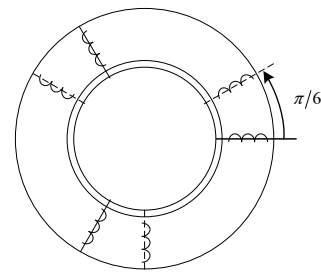

a)

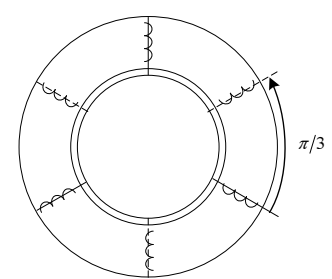

b)

1.2 pav. Šešiafazio asinchroninio variklio statoriai: a) perstumtų statoriaus fazinių apvijų; b) tipinès konstrukcijos

Fig. 1.2. Stators of six phase induction motor: a) split - phase; b) typical construction

Tipinès konstrukcijos šešiafazio asinchroninio variklio statorius pateiktas 1.2 paveikslo b) atvejis. Jis turi dvi identiškas statoriaus apvijų grupes. Tai reiškia, kad statoriaus apvijų grupès turi vienodą polių skaičių ir turi identiškus parametrus. Statoriaus fazinių apvijų kampinis poslinkis yra 60 elektrinių laipsnių.

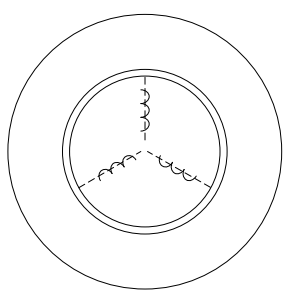

a)

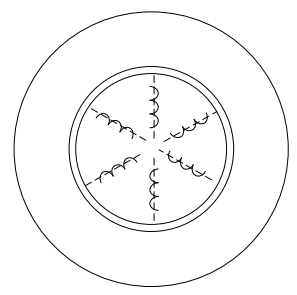

b)

1.3 pav. Šešiafazio asinchroninio variklio rotoriai: a) turintis trifazę apviją; b) turintis šešiafazę apviją

Fig. 1.3. Rotors of six phase induction motor: a) with three phase winding; b) with six phase winding

Šešiafaziai asinchroniniai varikliai pagal rotoriaus apvijų skaičių dažniausiai yra skirstomi i du tipus: turintys trifazę rotoriaus apviją arba turintys šešiafazę rotoriaus apviją. Tokios klasifikacijos atvejai yra pateikti 1.3 paveiksle. Trifazio 
rotoriaus apvijų kampinis poslinkis yra 120 elektrinių laipsnių, o šešiafazès apvijos - 60 elektrinių laipsnių. Žinoma, kad gali būti nagrinejjamos nesimetrinès sistemos ir kampai tarp rotoriaus fazinių apvijų gali būti skirtingi nuo čia paminètų atvejų.

Laboratorijose gali būti nagrinejjami aukščiau pateiktų statoriaus ir rotoriaus konstrukcijų skirtingų kombinacijų atvejai: pavyzdžiui, tipinis šešiafazis asinchroninis variklis, turintis trifazę rotoriaus apviją arba tipinis šešiafazis asinchroninis variklis, turintis šešiafazę rotoriaus apviją ir t.t.

Šioje disertacijoje tiriamas ịprastos konstrukcijos šešiafazis asinchroninis variklis, kurio statoriaus fazinès apvijos yra perstumtos viena kitos atžvilgiu 60 laipsniu kampu, o rotoriuje suklota trifazè apvija.

Šešiafazio asinchroninio variklio kiekviena statoriaus fazinė apvija, pvz., A fazès, yra charakterizuojama savuoju induktyvumu, atitinkančiu elektrovarą, kurią indukuoja ta fazine apvija tekanti srovè $I_{\mathrm{A}}$, abipusiu sklaidos induktyvumu tarp kitų dviejų statoriaus apvijų $L_{l \mathrm{~m}}$, o taip pat tarpusavio induktyvumais tarp statoriaus ir kiekvienos rotoriaus apvijų $L_{m}$. Simetrinèse šešiafazèse elektros mašinose visų statoriaus fazinių apvijų savieji induktyvumai $L_{\mathrm{A}}, L_{\mathrm{B}}, L_{\mathrm{C}}, L_{\mathrm{X}}, L_{\mathrm{Y}}$, $L_{Z}$ lygūs, visų statoriaus apvijų abipusiai induktyvumai $L_{S}$ lygūs, taip pat abipusis induktyvumas $L_{S R}$ tarp statoriaus ir rotoriaus apvijų yra lygūs. Rotoriaus apvijų abipusiai induktyvumai irgi priimami lygūs. Statoriaus ir rotoriaus savieji induktyvumai nepriklauso nuo rotoriaus posūkio kampo, lygiai kaip ir statoriaus apvijų abipusiai induktyvumai bei rotoriaus apvijų abipusiai induktyvumai. Tačiau statoriaus ir rotoriaus apvijų abipusiai induktyvumai priklauso nuo rotoriaus posūkio kampo (Rinkevičienè, Petrovas, 2005). Šešiafazio asinchroninio variklio statoriaus apvijų itampų balanso lygtys užrašomos taip:

$$
\left\{\begin{array}{l}
u_{A}=\frac{\mathrm{d} \Psi_{A}}{\mathrm{~d} t}+R_{A} i_{A}, \\
u_{B}=\frac{\mathrm{d} \Psi_{B}}{\mathrm{~d} t}+R_{B} i_{B}, \\
u_{C}=\frac{\mathrm{d} \Psi_{C}}{\mathrm{~d} t}+R_{C} i_{C}, \\
u_{X}=\frac{\mathrm{d} \Psi_{X}}{\mathrm{~d} t}+R_{X} i_{X}, \\
u_{Y}=\frac{\mathrm{d} \Psi_{Y}}{\mathrm{~d} t}+R_{Y} i_{Y}, \\
u_{Z}=\frac{\mathrm{d} \Psi_{Z}}{\mathrm{~d} t}+R_{Z} i_{Z} .
\end{array}\right.
$$


Analogiškai jos užrašomos ir rotoriaus apvijoms:

$$
\left\{\begin{array}{l}
u_{a}=\frac{\mathrm{d} \Psi_{a}}{\mathrm{~d} t}+R_{a} i_{a}, \\
u_{b}=\frac{\mathrm{d} \Psi_{b}}{\mathrm{~d} t}+R_{b} i_{b}, \\
u_{c}=\frac{\mathrm{d} \Psi_{c}}{\mathrm{~d} t}+R_{c} i_{c} .
\end{array}\right.
$$

Asinchroninio variklio lygčiu fazinèje koordinačių sistemoje sprendimas yra plačiau nagrinètas šaltiniuose (Petrovas, 2007; Robyns, et al., 2012).

Šešiafazio asinchroninio variklio transformavimui i dvifazi yra daromos šios prielaidos:

- oro tarpas pastovus,

- neatsižvelgiama ị magnetinį įsotinimą,

- neatsižvelgiama ị šerdies nuostolius,

- itampos ir srovès kinta sinuso dèsniu.

Sinchroniniu greičiu besisukančioje koordinačiu sistemoje šešiafazio asinchroninio variklio modeli aprašo Krono lygtys. Statoriaus ir rotoriaus kintamieji transformuojami i sinchroniniu greičiu besisukančią koordinačių sistemą $d^{e}-q^{e}$.

Statoriaus įtampų balansas stacionarioje koordinačių sistemoje aprašomas lygtimis (Nabi, et al., 2011; Levi, et al., 2011):

$$
\begin{aligned}
& u_{q s 1}^{s}=R_{s} i_{q s 1}+s \Psi_{q s 1}^{s}, \\
& u_{d s 1}^{s}=R_{s} i_{d s 1}+s \Psi_{d s 1}^{s}, \\
& u_{q s 2}^{s}=R_{s} i_{q s 2}+s \Psi_{q s 2}^{s}, \\
& u_{d s 2}^{s}=R_{s} i_{d s 2}+s \Psi_{d s 2}^{s},
\end{aligned}
$$

šiose lygtyse: $u_{q s 1}^{s}, u_{q s 2}^{s}$ - statoriaus ịtampu projekcijos i $q^{s}$ ašị; $u_{d s 1}^{s}, u_{d s 2}^{s}-$ statoriaus įtampu projekcijos i $d^{S}$ aši $; R_{s}$ - statoriaus aktyvioji varža; $i_{q s 1}, i_{q s 2}$ - statoriaus srovių projekcijos i $q^{s}$ aši; $i_{d s 1}, i_{d s 2}$ - statoriaus srovių projekcijos i $d^{s}$ aši; $\Psi_{q s 1}^{s}, \Psi_{q s 2}^{s}-$ statoriaus surištuju srautu projekcijos i $q^{s}$ aši; $\Psi_{d s 1}^{s}$, $\Psi_{d s 2}^{s}$ - statoriaus surištųų srautų projekcijos ị $d^{s}$ ašį, $s$-Laplaso operatorius. 
1.3 lygtis konvertavus ị besisukančią koordinačių sistemą, gaunama (Nabi, et al. 2011; Levi, et al. 2011):

$$
\begin{aligned}
& u_{q s 1}=R_{s} i_{q s 1}+s \Psi_{q s 1}+\omega_{e} \Psi_{d s 1}, \\
& u_{d s 1}=R_{s} i_{d s 1}+s \Psi_{d s 1}-\omega_{e} \Psi_{q s 1}, \\
& u_{q s 2}=R_{s} i_{q s 2}+s \Psi_{q s 2}+\omega_{e} \Psi_{d s 2}, \\
& u_{d s 2}=R_{s} i_{d s 2}+s \Psi_{d s 2}-\omega_{e} \Psi_{q s 2},
\end{aligned}
$$

čia $\omega_{e}-$ dvipolio variklio sinchroninis greitis, lygus sukamojo magnetinio lauko greičiui.

Paskutiniai 1.4 lygčiu nariai yra greičio elektrovaros atsiradusios dèl koordinačių sukimosi. Todèl, kai $\omega_{e}=0$, šios lygtys atitinka stacionariosios koordinačių sistemos lygtis.

Nejudančiam rotoriui, kai $\omega_{r}=0$, ittampos užrašomos (Nabi, et al., 2011; Levi, et al., 2011):

$$
\begin{aligned}
& u_{q r}^{s}=R_{r} i_{q r}+s \Psi_{q r}^{s}, \\
& u_{d r}^{s}=R_{r} i_{d r}+s \Psi_{d r}^{s},
\end{aligned}
$$

čia $u_{q r}^{s}$ - rotoriaus įtampos projekcija i $q^{s}$ aši; $u_{d r}^{s}$ - rotoriaus itampos projekcija i $d^{s}$ ašį; $i_{q r}$ - rotoriaus srovès projekcija $q^{s}$ ašį; $i_{d r}$ - rotoriaus srovès projekcija i $d^{S}$ ašį; $\Psi_{d r}^{s}$ - rotoriaus surištojo srauto projekcija ị $d^{S}$ aši; $\Psi_{q r}^{s}$ - rotoriaus surištojo srauto projekcija ị $q^{s}$ aši.

Rotorius sukasi greičiu $\omega_{r}$, todèl magnetinio lauko sinchroniniu greičiu judančios ašys $d^{e}-q^{e}$ rotoriaus atžvilgiu juda $\omega_{e}-\omega_{r}$ greičiu. Todèl besisukančioje koordinačių sistemoje rotoriaus lygtys užrašomos taip (Nabi, et al. 2011; Levi, et al. 2011):

$$
\begin{aligned}
& u_{q r}=R_{r} i_{q r}+s \Psi_{q r}+\left(\omega_{e}-\omega_{r}\right) \Psi_{d r}, \\
& u_{d r}=R_{r} i_{d r}+s \Psi_{d r}-\left(\omega_{e}-\omega_{r}\right) \Psi_{q r} .
\end{aligned}
$$

Pagal (1.4) ir (1.5) lygtis sudarytos variklio dinaminio modelio ekvivalentinès schemos besisukančioje $d^{e}-q^{e}$ koordinačių sistemoje parodytos 1.4 ir 1.5 paveiksluose (Singh, et al., 2003; Venter, 2012). 


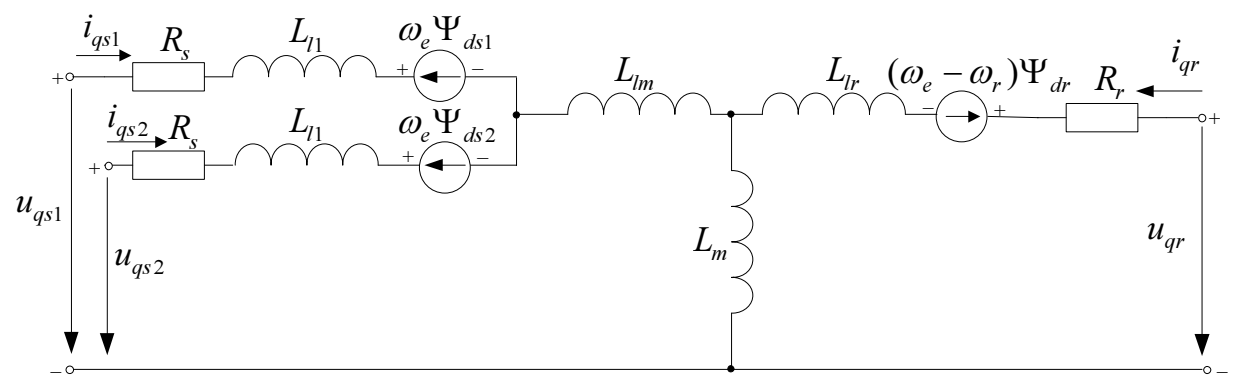

1.4 pav. Variklio dinaminès $d^{e}-q^{e}$ ekvivalentinès schemos $q^{e}$ ašie grandinè

Fig. 1.4. Dynamic equivalent per phase circuit $d^{e}-q^{e}$ of induction motor, $q^{e}$ cirquit

$d^{e}-q^{e}$ dinaminio modelio privalumas, kad visi stacionariosios koordinačių sistemos kintamieji (itampos, srovès, srautai) pavirsta nuolatiniais dydžiais.

Disertacijoje šešiafazio asinchroninio variklio modeliai bus sudaromi $d^{e}-q^{e}$ koordinačių sistemoje, todèl supaprastinant žymėjimus, ši koordinačių sistema bus žymima $d-q$.

Pagal 1.4 ir 1.5 paveiksluose pateiktą variklio dinaminę $d^{e}-q^{e}$ ekvivalentinę schemą surištieji srautai išreiškiami taip (Singh, et al., 2003):

$$
\begin{aligned}
& \Psi_{q s 1}=L_{l s} i_{q s 1}+L_{l m}\left(i_{q s 1}+i_{q s 2}\right)+L_{m}\left(i_{q s 1}+i_{q s 2}+i_{q r}\right), \\
& \Psi_{d s 1}=L_{l s} i_{d s 1}+L_{l m}\left(i_{d s 1}+i_{d s 2}\right)+L_{m}\left(i_{d s 1}+i_{d s 2}+i_{d r}\right), \\
& \Psi_{q s 2}=L_{l s} i_{q s 2}+L_{l m}\left(i_{q s 1}+i_{q s 2}\right)+L_{m}\left(i_{q s 1}+i_{q s 2}+i_{q r}\right), \\
& \Psi_{d s 2}=L_{l s} i_{d s 2}+L_{l m}\left(i_{d s 1}+i_{d s 2}\right)+L_{m}\left(i_{d s 1}+i_{d s 2}+i_{d r}\right), \\
& \Psi_{q r}=L_{l r} i_{q r}+L_{m}\left(i_{q s 1}+i_{q s 2}+i_{q r}\right), \\
& \Psi_{d r}=L_{l r} i_{d r}+L_{m}\left(i_{d s 1}+i_{d s 2}+i_{d r}\right),
\end{aligned}
$$

čia $L_{l s}$ - statoriaus apvijų sklaidos induktyvumas; $L_{l m}$ - abipusis statoriaus apvijų sklaidos induktyvumas; $L_{m}-$ abipusis statoriaus ir rotoriaus apvijų induktyvumas; $L_{l r}$ - rotoriaus apvijų sklaidos induktyvumas. 


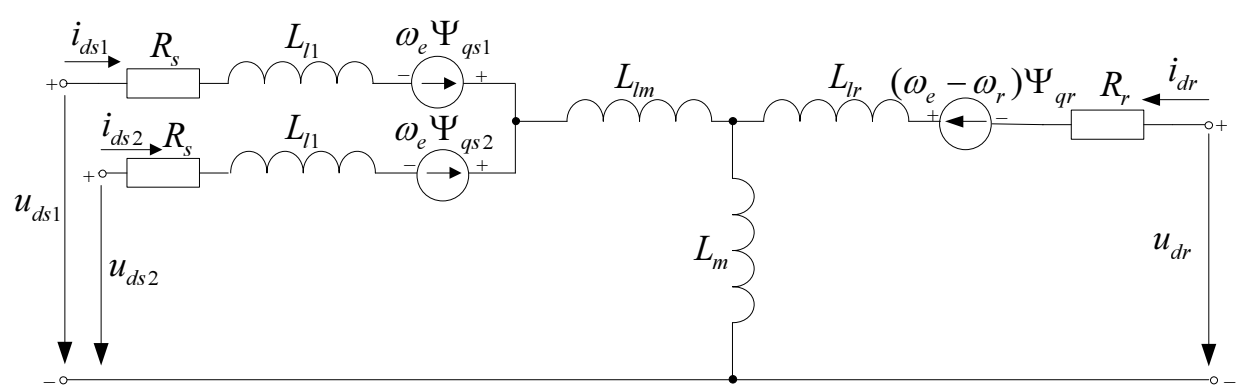

1.5 pav. Variklio dinaminès $d^{e}-q^{e}$ ekvivalentinès schemos $d^{e}$ ašies grandinè

Fig. 1.5. Dynamic equivalent per phase circuit $d^{e}-q^{e}$ of induction motor, $d^{e}$ cirquit

Šešiafazio asinchroninio variklio momentas $M_{e}$ apskaičiuojamas taip:

$$
M_{e}=\frac{3}{2}\left(\frac{P}{2}\right)\left(\frac{L_{m}}{L_{r}}\right)\left[\Psi_{d r}\left(i_{q s 1}+i_{q s 2}\right)-\Psi_{q r}\left(i_{d s 1}+i_{d s 2}\right)\right] .
$$

Pavaros judesio lygtis:

$$
\frac{d \omega}{d t}=\frac{1}{J}\left(M_{e}-M_{s t}\right)
$$

čia $M_{s t}$-statinis apkrovos momentas; $J$-pavaros inercijos momentas.

Šešiafazès pavaros dinamines charakteristikas galima gauti dviem būdais: lygtis galima užrašyti matricine forma ir jas spręsti kompiuteriu arba modelị sudaryti iš elementarių blokų ir pavarą tirti sistemų imitacijai parašyta kompiuterine programa. Dažniausiai daugiafazių pavarų tyrimui yra taikomas pirmasis atvejis (Lu, et al., 2005; Nabi, et al., 2011; Gregor, et al., 2008; Miranda, et al., 2009; Levi, et al., 2007; Wang, et al., 2011; Dasika, et al., 2012; Renukadevi, 2011). Jị taikant būtini geri programavimo ịūdžiai, nes objekto modelis sudaromas pagal ji aprašančių diferencialinių lygčių sistemą, kuriai spręsti taikomi skaitiniai diferencialinių lygčių sprendimo būdai. Patogesnis ir universalesnis pavaros tyrimas yra naudojant sistemų imitacijai parašyta programa. Dažniausiai imitaciniai modeliai sudaromi naudojant MathWorks ${ }^{\circledR}$ kompanijos į Matlab ${ }^{\circledR}$ sudèti įeinanti Simulink ${ }^{\circledR}$ programa.

Abiem atvejais sudaryti pavaros modeli yra sudètinga, tačiau imitacinis modelis Simulink ${ }^{\circledR}$ aplinkoje yra žymiai patogesnis tyrejui. Pirmuoju atveju norint tirti sistemas reikalinga, kad tiriantis asmuo labai gerai išmanytų programavimo kalbą. Antruoju atveju tyrèjas elementariuose grafiniuose 
objektuose gali greitai ir patogiai keisti sistemos parametrus. Jis gali gauti tarpinius matavimo rezultatus pageidaujamuose sistemų mazguose. Tyrejas turi galimybę pagal gaunamas dinamines charakteristikas elementariai ir patogiai keisti pradinius pavaros parametrus. Imitaciniai modeliai sukurti Simulink ${ }^{\mathbb{B}}$ aplinkoje gali būti naudojami su realiais įrenginiais sistemų darbo imitacijai. Todèl jie yra žymiai universalesni už matricine forma sprendžiamus kompiuterinius variklio modelius.

Matematiniu modelių adekvatumui realioms sistemoms įvertinti yra atliekami eksperimentiniai tyrimai. Tokie tyrimai atliekami ir su daugiafaziu asinchroninių varikliu kompiuteriniais modeliais. Tam naudojami individualiai projektuojami daugiafaziai asinchroniniai varikliai. Pradžioje yra sudaroma vieno ar kito tipo apvijos schema, apskaičiuojamos magnetovaros, palyginama jų harmoninè sudetis ir parenkamas efektyviausias apvijos tipas (Bukšnaitis, 2007; Bugenis, et al., 2008). Variklio projektavimas prasideda nuo apvijos tipo parinkimo, jos schemos sudarymo ir magnetovaros skaičiavimo, todèl ši problema yra aktuali ir spręstina, kuriant daugiafazius variklius (Nanoty, et al., 2013, Drozdowski, 2011).

\subsection{Asinchroninių elektros pavarų valdymo metodai}

Asinchroninio variklio rotoriaus apsisukimų skaičius per vieną mintutę $n$ yra išreiškiamas:

$$
n=\frac{120 f}{P}(1-S),
$$

čia $f$ - maitinimo ịtampos dažnis; $P$ - polių skaičius, $S$ - slydimas. Pagal (1.10) formulę variklio sukimosi greiti galima keisti valdant maitinimo įtampos dažnį, variklio polių skaičių arba slydimą (Ahmad, 2010; Gečys, et al., 2010).

Variklio polių skaičius parenkamas projektavimo metu. Atsižvelgiant i tai, variklio rotoriaus sukimosi greičio reguliavimas keičiant polių skaičiu yra neperspektyvus. Šiuolaikinèse elektros pavarose maitinimo itampos dažnis ir slydimas yra pagrindiniai valdomieji dydžiai.

Principiniai daugiafazių varikliu greičio valdymo metodai yra tokie patys kaip ir trifazių variklių (Levi, 2008).

Asinchroninio variklio valdymo metodai yra klasifikuojami i skaliarinius ir vektorinius (Trzynadlowski, Andrzej, 2001). Sistemoms, kurioms nèra keliami aukšti valdymo tikslumo reikalavimai, naudojamas skaliarinis valdymo metodas. Didesnio valdymo tikslumo reikalaujančiose pavarose yra naudojamas vektorinis valdymo metodas. Abiem metodams bendra tai, kad vienaip ar kitaip keičiama įtampa ir jos dažnis. Tam naudojami dažnio keitikliai. 
Dažnio keitiklis yra sudètingas įtaisas, kurio paskirtis formuoti keičiamo dažnio ir įtampos tinklą, prie kurio prijungus asinchronini elektros variklį, jo apvijomis tekètų sinuso formos srovès ir jos būtų tokio dažnio, fazès ir dydžio, kad variklio rotorius suktųsi norimu greičiu, norima kryptimi ir turètų reikiamą sukimo momentą.

Dažninių elektros pavarų valdymo klasifikacija pateikta 1.6 paveiksle.

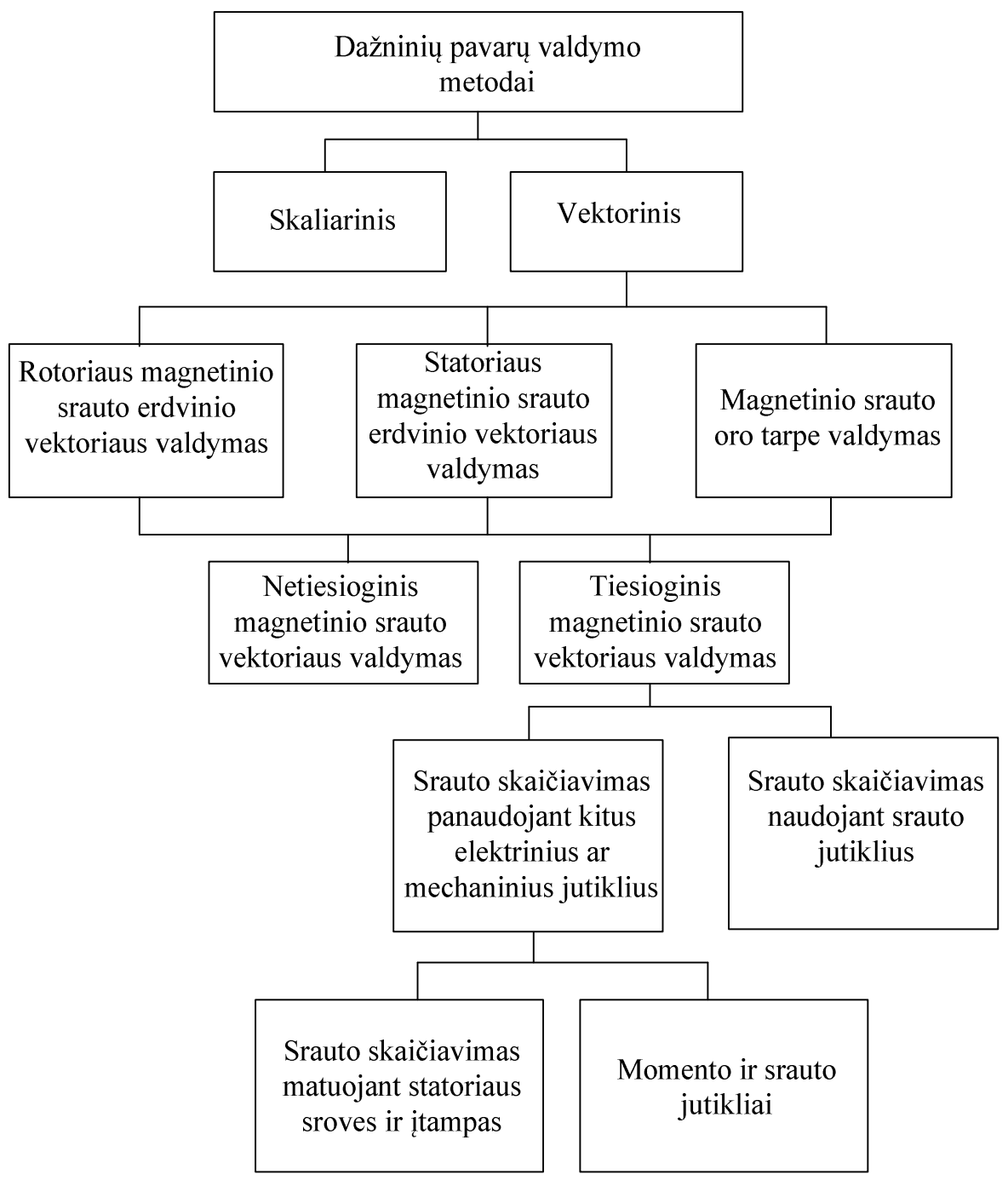

1.6 pav. Dažninių elektros pavarų valdymo būdų klasifikacija

Fig. 1.6. Classification of control of variable speed drives 
Skaliarinis valdymas yra vienas populiariausių pavarų valdymo metodų ir naudojamas iki 80 procentų atvejų. Šio valdymo metodo esmè yra tai, kad siekiant valdyti magnetini srautą yra valdoma variklio įtampa, o siekiant valdyti variklio momentą yra valdomas dažnis arba slydimas (Kazmierkowski, et al., 2002; Bolton, 2003; Joliet, 2013; Freescale, 2006). Be to, magnetinis srautas yra dažnio funkcija,o momentas - įtampos funkcija.

Pastoviam, dažniausiai vardiniam, magnetinio srauto palaikymui statoriaus itampa turi būti reguliuojama proporcingai dažniui. Tai vienas populiariausių skaliarinio valdymo metodų (Reljic, et al., 2006; Leonhard, 2001; Jian, 2001). Nagrinejjamu atveju variklio veleno statinè apkrova yra pastovi, todèl valdymui grịžtamojo ryšio signalas yra nebūtinas. Greičio jutiklis praktikoje naudojamas tais atvejais, kai norima gauti informaciją apie greičio pokyčius.

Praktikoje dažniausiai susiduriama su trimis statinès apkrovos atvejais: kai siekiama išlaikyti pastovų sukimo momentą, siekiama išlaikyti pastovią galią ir kuomet variklis apkraunamas ventiliatorine apkrova.

Pirmuoju atveju, variklio veleno pastoviam sukimo momento palaikyti turi būti tenkinama sąlyga:

$$
\frac{U}{f}=\text { const., }
$$

t. y. maitinimo šaltinio įtampa turi būti keičiama proporcingai dažniui. 1.7 paveiksle pateikta itampos valdymo charakteristika, kai $\frac{U}{f}=$ const. valdymo charakteristika. Grafike pažymèta: $U_{s}$ - statoriaus įtampa, $U_{\mathrm{s}, n o m}-$ nominalioji itampa, $U_{\mathrm{s}, 0}$ - pradinè itampa, $f$ - tinklo dažnis, $f_{\text {nom. }}-$ vardinis tinklo dažnis.

Antruoju atveju, siekiant išlaikyti pastovią variklio veleno galią, naudojamas toks reguliavimo dèsnis:

$$
\frac{U}{\sqrt{f}}=\text { const. }
$$

t. y. maitinimo šaltinio ịtampa turi būti tiesiogiai proporcinga maitinimo tinklo dažnio kvadratinei šakniai.

Trečiuoju atveju, kai apkrova ventiliatorinè, maitinimo šaltinio įtampa turi būti tiesiogiai proporcinga maitinimo tinklo dažnio kvadratui:

$$
\frac{U}{f^{2}}=\text { const } \text {. }
$$


Šis dèsnis vadinamas kvadratinio valdymo dèsniu.

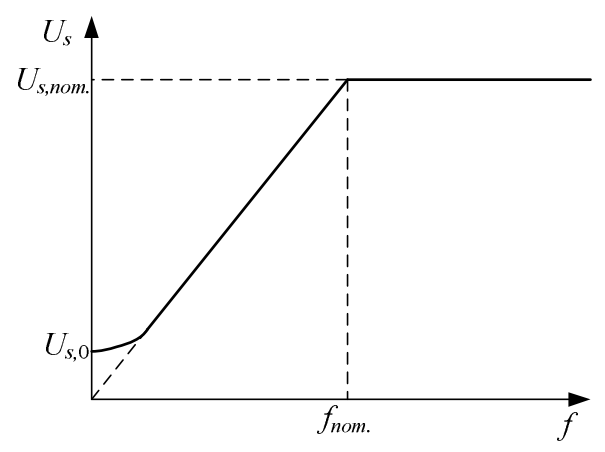

1.7 pav. Skaliarinio valdymo $U / f=$ const. charakteristika

Fig. 1.7. Voltage versus frequency relation in the constant $\mathrm{V} / \mathrm{Hz}$ controlled drives

Skaliarinio valdymo sistemos, kai $\frac{U}{f}=$ const., struktūrinè schema pateikta 1.8 paveiksle. Struktūrinejje schemoje $\omega_{\mathrm{sl}}$ yra fiksuotas variklio kampinis slydimo greitis, atitinkantis $50 \%$ vardinio apkrovos momento. Jis sumuojamas su nuostato signalu $\omega_{\mathrm{M}}^{*}$ ir gaunamas sinchroninis greičio nuostato $\omega_{\text {syn. }}^{*}$ signalas. Toliau, $\omega_{\text {syn. }}^{*}$ yra padauginamas iš polių porų skaičiaus $p$, ir gaunamas maitinimo įtampos dažnis $\omega^{*}$. Šis dažnis dar naudojamas kaip įejjimo signalas itampos reguliatoriui. Reguliatorius generuoja inverterio itampos nuostato signalą $U^{*}$, pagal kuri nustatoma inverterio išejimo įtampa.

1.8 paveiksle pateiktoje schemoje parodytas srovès ribotuvas naudojamas tada, kai variklio srovè viršija leistiną vardinę srovę ir reikia sumažinti inverterio išèjimo įtampą. Srove $i_{\mathrm{dc}}$ matuojama nuolatinès srovès šynoje. Nuolatinès srovės grižtamojo ryšio signalo naudojimas yra patogesnis negu kintamosios.

Naudojant tokią valdymo sistemą pasiekti didelio valdymo tikslumo negalima, nes kintant apkrovos momentui kartu kinta ir slydimas. Tačiau daugeliui prietaisų, pvz. siurbliams, statybinio skiedinio maišytuvams, ventiliatoriams nèra keliami aukšti valdymo tikslumo reikalavimai ir gali būti naudojama tokia valdymo sistema.

Didesniam valdymo tikslumui pasiekti, kai variklio greitis reguliuojamas keičiant ịtampos ir dažnio santykị, naudojama uždaroji valdymo sistema su slydimo kompensavimo reguliavimu. 1.8 paveiksle pateikta patobulinta schema pridedant slydimo kompensavimo reguliavimą, apskaičiuotą pagal nuolatinès srovès šynoje išmatuotą srovę $i_{\mathrm{dc}}$. Čia slydimo kompensatorius generuoja 
slydimo signalą $\omega_{\mathrm{sl}}$, kuris proporcingas $i_{\mathrm{dc}}$. Skaliariniu būdu valdomos elektromechaninès sistemos su slydimo reguliatoriumi pavyzdys pateiktas 1.9 paveiksle.

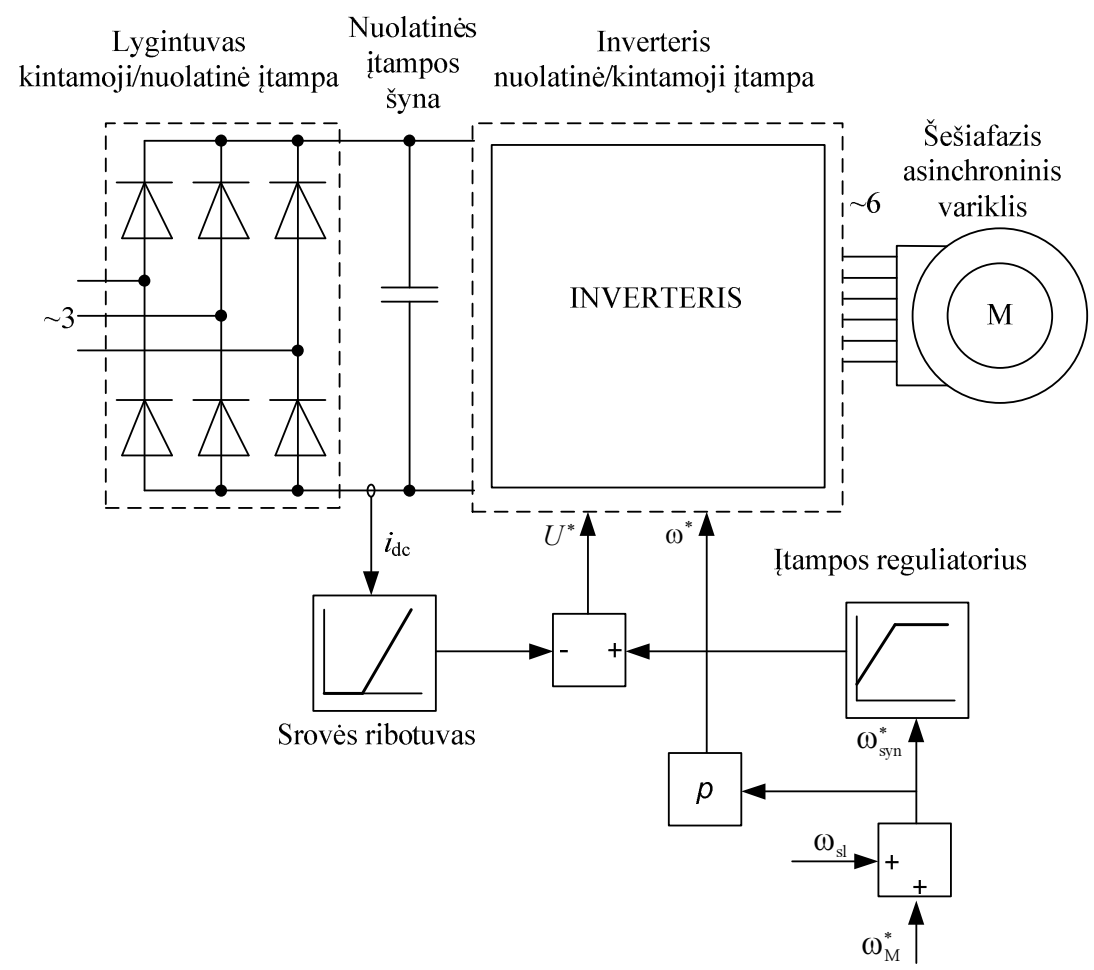

1.8 pav. Skaliarinio valdymo sistema, kai $U / f=$ const.

Fig. 1.8. Scalar control drive system, at $U / f=$ const.

Kitas skaliariniu būdu valdomos elektromechaninès sistemos su slydimo reguliatoriumi pavyzdys pateiktas 1.10 paveiksle. Šioje sistemoje kampinio greičio grižžtamojo ryšio signalas $\omega_{\mathrm{M}}$ yra lyginamas su nuostato kampiniu greičiu $\omega_{M}^{*}$. Taip gaunamas greičio paklaidos signalas $\Delta \omega_{M}$, kuris per greičio reguliatorių (paprastai PI arba PID) patenka ì slydimo reguliatorių. Slydimo reguliatorius generuoja slydimo nuostato signalą $\omega_{\mathrm{sl}}^{*}$. Slydimo greitis turi būti ribojamas norint išvengti nestabilumo ir viršįtampių atsiradimo. Todèl slydimo reguliatoriaus statiné charakteristika pasiekia soties vertę, kol slydimas yra 
mažesnis už kritinę slydimo vertę. Susumavus $\omega_{\mathrm{sl}}^{*}$ ir $\omega_{\mathrm{M}}$ gaunamas sinchroninis nuostato greitis $\omega_{\text {syn. }}^{*}$.

Skaliarinio valdymo sistemos gali būti ne tik su palaikomu pastoviu įtampos ir dažnio santykiu. Egzistuoja sistemos, kuriose palaikomas pastovus statoriaus srovès ir slydimo santykis. Skaliarinio valdymo sistemose gali būti naudojamas nepriklausomas momento ir srauto valdymo algoritmas (Trzynadlowski, et al., 2001; Bose, 2002).

I skaliarinio valdymo sistemas įeinančių inverterių, kurie nuolatinę itampą keičia i šešiafazę kintamą ịtampą, modeliai kuriami Lietuvoje ir užsienyje (Lipinskis, et al., 2013; Lipinskis, 2013; Miranda, et al., 2009; Lipo, 1980; Oleschuk, et al., 2011; Gregor, et al., 2008; Nanoty, et al., 2012; Jones, et al., 2005).

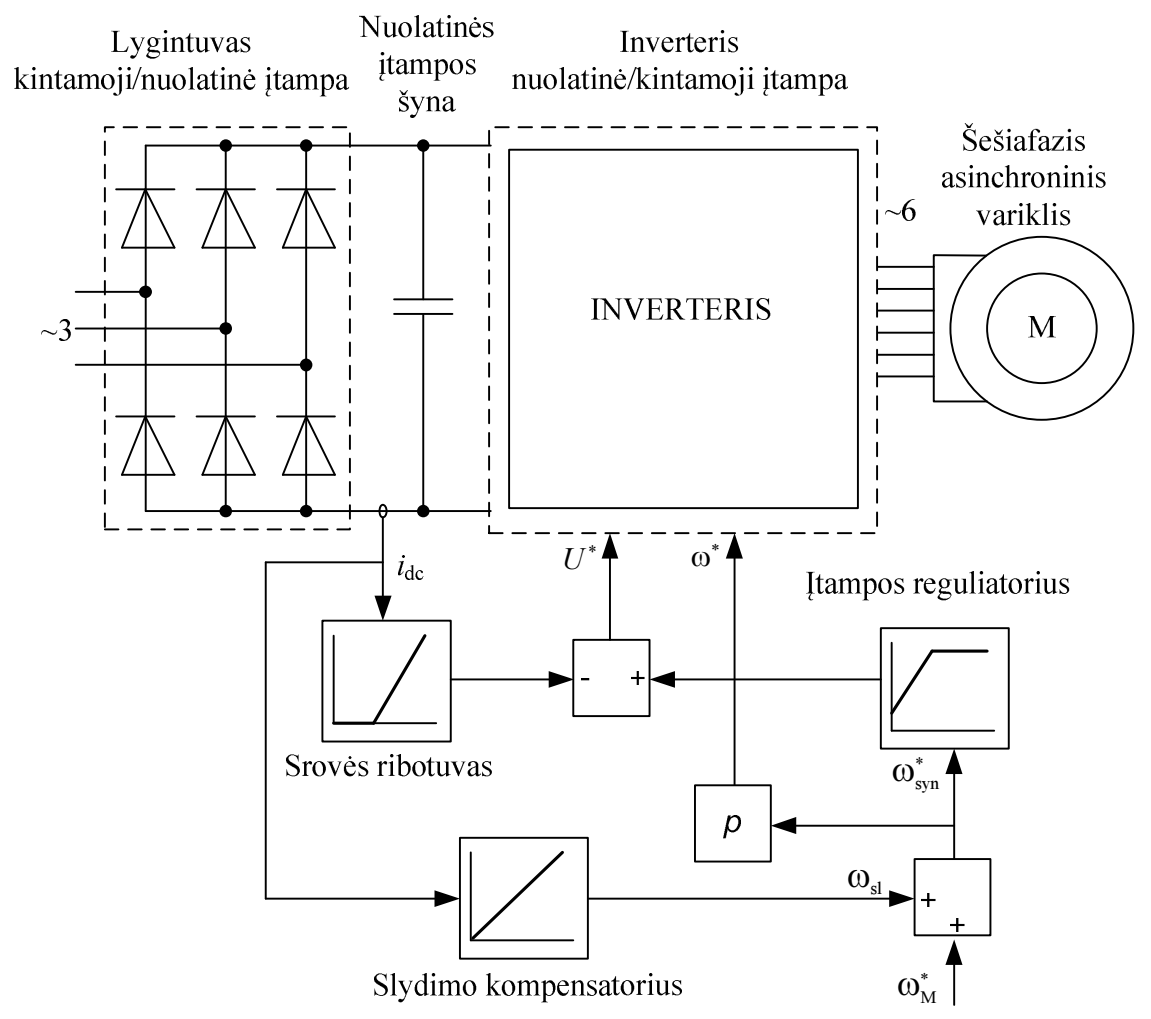

1.9 pav. Skaliarinio valdymo sistema su slydimo kompensavimu, kai $U / f=$ const.

Fig. 1.9. Scalar control drive system with slip compensation, at $U / f=$ const. 
Skaliarinio valdymo metodo taikymas negarantuoja geru elektros pavaros dinaminių charakteristikų, kadangi šio valdymo metodo algoritmas neatsižvelgia i variklio pereinamuosius vyksmus. Tai viena iš pagrindinių priežasčių, neleidžiančiu skaliariniam valdymui pasiekti didelio valdymo tikslumo. Tais atvejais, kai reikia atsižvelgti i variklio pereinamuosius vyksmus ir tiksliai valdyti varikli, naudojamas vektorinis valdymo metodas.

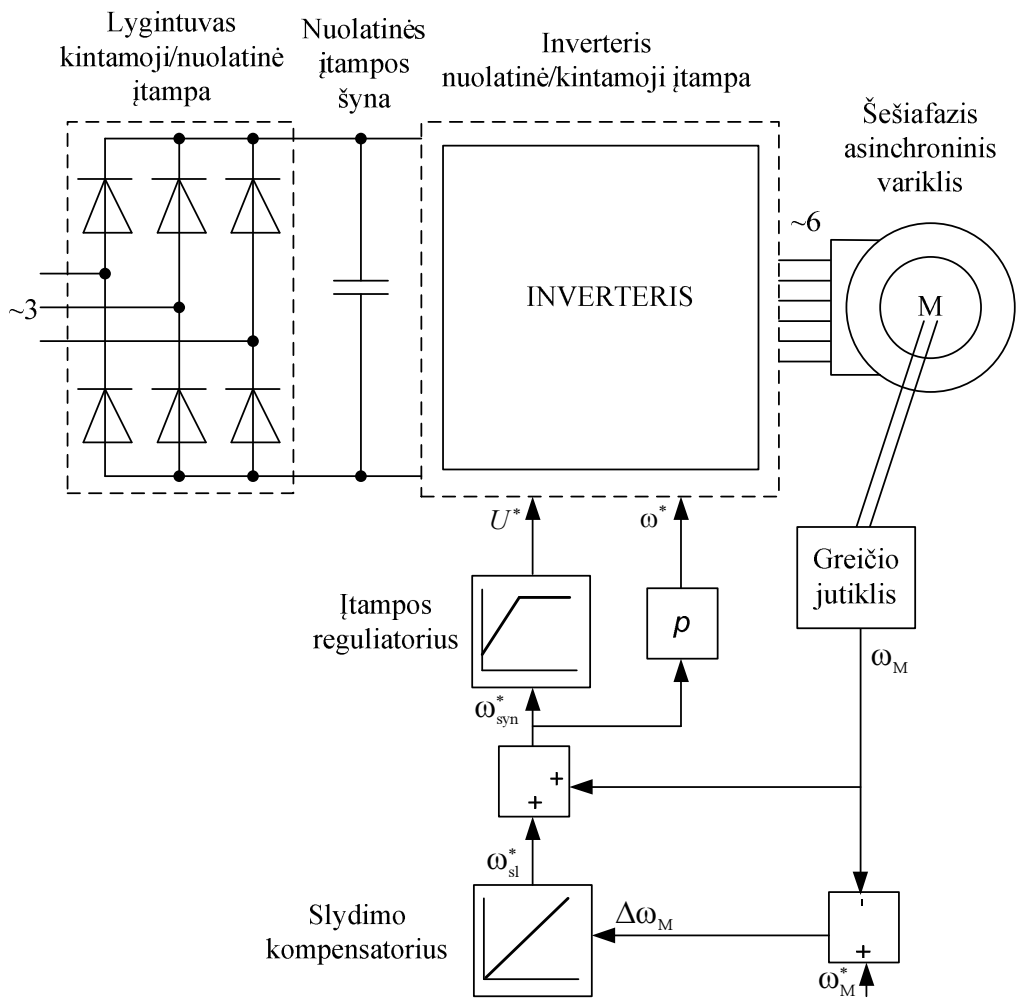

1.10 pav. Skaliariniu būdu valdoma elektromechaninè sistema su slydimo reguliavimu

Fig. 1.10. Scalar controlled drive system with slip controller

Vektorinio valdymo principai buvo suformuluoti XX amžiaus pradžioje, kuomet sudètingi skaičiavimai buvo atliekami rankiniu būdu. Dèl skaičiavimo sudètingumo nebuvo didelio susidomejjimo šiuo valdymo metodu. Tačiau atsiradus skaičiavimo mašinoms, o vèliau kompiuteriams jis labai išpopuliarejo. Prie to labiausiai prisidejo Vokietijos mokslininkai Blaschke, Hasse, Leonhard ir Švedijos mokslininkas Jonsson. Jie suformulavo pagrindinius vektorinio valdymo principus. 
Asinchroniniuose varikliuose momentas gali būti valdomas valdant statoriaus sroves. Pagrindinis vektorinio valdymo uždavinys - atskirti statoriaus srovès dedamąsias, kurių viena atsakinga už srauto kūrimą, o kita - už momento kūrimą. Vektoriškai valdant turi būti valdomi du srovès parametrai: fazinis kampas ir modulis, kitais žodžiais sakant, srovès vektorius. Tai ir yra priežastis, del kurios šis metodas vadinamas vektoriniu.

Yra skiriami du pagrindiniai vektorinio valdymo metodai. Vienas jų vadinamas tiesioginio arba grižtamojo ryšio (angl. feedback) vektoriniu valdymo metodu, kurị sukūrè Blaschke (Blaschke, 1972). Antrasis - netiesioginio valdymo metodas, kuri sukūrè Hasse (Hasse, 1969). Pagrindinis šių metodų skirtumas yra valdymo signalams formuoti taikomi skirtingi bazinių vektorių formavimo būdai. Transformuotoje koordinačių sistemoje srovès dedamosios kryptis gali būti sutapdinama su rotoriaus srautu, srautu oro tarpe arba statoriaus srautu. Pagal tai skiriami trys vektorinio valdymo atvejai: rotoriaus srauto erdvinio vektoriaus valdymas, statoriaus srauto erdvinio vektoriaus valdymas ir srauto oro tarpe valdymas (Rashid, 2001).

Daugiafaziams varikliams, turintiems simetrinę statoriaus apviją, problema supaprasteja ir gali būti taikomos tos pačios vektorinio valdymo schemos kaip ir trifaziams varikliams (Levi, 2008). Daugiafaziu variklių vektorinio valdymo atvejai nagrinejami straipsniuose (Cammilis, et al., 2001; Bojoi, et al., 2002; Bojoi, et al., 2003; Singh, et al., 2005; Bojoi, et al., 2003; Bojoi, et al., 2006; Hou, et al., 2003; Sudhoff, et al., 1997; Vukosavic, et al., 2005; Bojoi, et al., 2005; Hua, et al., 2006; Bojoi, et al., 2006; Kianinezhad, et al., 2005; Kianinezhad, 2006; Kianinezhad, et al., 2004).

\subsection{Pirmojo skyriaus išvados ir disertacijos uždavinių formulavimas}

Apžvelgus literatūrą disertacijos tema nustatyta, kad šešiafaziai asinchroniniai varikliai kai kuriomis savybèmis yra pranašesni negu trifaziai varikliai ir yra perspektyvūs lokaliose sistemose. Todèl disertacijos įvade iškelti uždaviniai yra aktualūs ir spręstini.

1. Literatūros analizè rodo, kad šešiafazio asinchroninio variklio privalumai: didesnè galia tūrio vienetui ir didesnis atsparumas gedimams lyginant juos su trifaziais asinchroniniais varikliais yra reikšmingi naudojant šiuos variklius lokaliose sistemose, todél šešiafazių asinchroninių variklių tyrimas yra perspektyvus. 
2. Literatūroje plačiai išanalizuoti kintamosios srovès variklių matematiniai modeliai, koordinačių sistemos transformavimo principas, greičio reguliavimo metodai. Aprašyti asinchroninių variklių matematiniai modeliai ir jų sudarymo metodika yra tinkama šešiafazių elektros pavarų imitaciniams modeliams sudaryti.

3. Elektros pavarų imitaciniai modeliai Simulink ${ }^{\mathbb{R}}$ aplinkoje yra pranašesni už matematinėmis skaičiavimo programomis sudarytus modelius, nes jais galima tirti pavaru dinaminius vyksmus ir juos taikyti realiose sistemose įrenginių darbui imituoti.

4. Variklio statoriaus apvijų tipas turi esminę itaką variklio sukimo momentui, galiai, naudingumo ir galios faktoriams bei vibracijoms, todèl tikslinga tirti skirtingos statoriaus konstrukcijos šešiafazius asinchroninius variklius.

5. Eksperimentinių tyrimų reikšmė yra aktuali ir neginčytina kuriant naują kompiuterinị modelị ir siekiant išsiaiškinti jo adekvatumą realiosioms sistemoms.

Darbo tikslui pasiekti darbe reikia spręsti šiuos uždavinius:

1. Sudaryti ir ištirti sutelktają dvisluoksnę šešiafazę sutrumpinto žingsnio ir sutelktają dvisluoksnę šešiafazę poliaus žingsnio apvijas ir įvertinti jų efektyvumą.

2. Sudaryti šešiafazio asinchroninio variklio kompiuterinius modelius pagal srovių ir srautų išraiškas, kuriuos naudojant galima būti tirti šešiafazio asinchroninio variklio dinaminius vyksmus.

3. Sudaryti skaliariniu būdu valdomos šešiafazès asinchroninès pavaros imitacinį modelį ir ištirti variklio pereinamuosius vyksmus apkraunant ji skirtingo dydžio apkrovomis.

4. Suprojektuoti ir sukonstruoti šešiafazio asinchroninio variklio eksperimentini tyrimų stendą, kuriuo galima būtų tirti šešiafazio asinchroninio variklio paleidimo pereinamuosius vyksmus ir remiantis gautais eksperimentiniais duomenimis patikrinti sukurtu imitaciniu modelių adekvatumą. 


\section{2}

\section{Šešiafazių asinchroninių varikliụ modelių sudarymo metodika}

Skyriuje pateikta šešiafazių asinchroninių variklių kompiuterinių modeliu sudarymo metodika. Imitaciniai modeliai sudaryti Matlab $^{\mathbb{B}}$ Simulink $^{\mathbb{R}}$ programavimo kalba, kuria galima kurti ir modeliuoti sistemas.

Pirmiausia sudarome šešiafazio asinchroninio variklio imitacini modelį pagal statoriaus ir rotoriaus srovių išraiškas. Jis gaunamas apjungiant tris modelius: pereinamujų vyksmų statoriaus grandinejje modelį, rotoriaus grandinės modelị ir momento skaičiavimo modeli.

Skyriuje pateikiame šešiafazio asinchroninio variklio imitacinio modelio sudarymo metodika pagal statoriaus ir rotoriaus srautų išraiškas.

Skyriaus pabaigoje aprašomas imitacinių modelių naudojimas greitujų prototipų sistemose. Pateikiama greitujų prototipų konfigūracija.

Skyriaus tematika paskelbti keturi autoriaus straipsniai (Kundrotas, et al., 2011, Kundrotas, et al., 2011, Lisauskas, Kundrotas, et al., 2011, Rinkevičienè, Kundrotas, et al., 2013). 


\section{1. Šešiafazio asinchroninio variklio modelio sudarymas pagal srovių išraiškas}

Šešiafazio asinchroninio variklio lygtys pateiktos 1.3 skyriuje. İrašius srautų išraiškas (1.7) i itampų lygtis (1.4) ir (1.6) gauname srovių priklausomybes sinchroniškai besisukančioje koordinačių sistemoje:

$$
\begin{aligned}
& i_{q s 1}=\frac{1}{s} \frac{1}{\left(L_{l s}+L_{l m}+L_{m}\right)}\left\{u_{q s 1}-R_{s} i_{q s 1}-s\left(L_{l m}+L_{m}\right) i_{q s 2}-s L_{m} i_{q r}-\right. \\
& \left.-\omega_{e}\left[\left(L_{l s}+L_{l m}+L_{m}\right) i_{d s 1}+\left(L_{l m}+L_{m}\right) i_{d s 2}+L_{m} i_{d r}\right]\right\} \text {, } \\
& i_{q s 2}=\frac{1}{s} \frac{1}{\left(L_{l s}+L_{l m}+L_{m}\right)}\left\{u_{q s 2}-R_{s} i_{q s 2}-s\left(L_{l m}+L_{m}\right) i_{q s 1}-s L_{m} i_{q r}-\right. \\
& \left.-\omega_{e}\left[\left(L_{l s}+L_{l m}+L_{m}\right) i_{d s 2}+\left(L_{l m}+L_{m}\right) i_{d s 1}+L_{m} i_{d r}\right]\right\} \text {, } \\
& i_{d s 1}=\frac{1}{s} \frac{1}{\left(L_{l s}+L_{l m}+L_{m}\right)}\left\{u_{d s 1}-R_{s} i_{d s 1}-s\left(L_{l m}+L_{m}\right) i_{d s 2}-\right. \\
& \left.-s L_{m} i_{d r}+\omega_{e}\left[\left(L_{l s}+L_{l m}+L_{m}\right) i_{q s 1}+\left(L_{l m}+L_{m}\right) i_{q s 2}+L_{m} i_{q r}\right]\right\}, \\
& i_{d s 2}=\frac{1}{s} \frac{1}{\left(L_{l s}+L_{l m}+L_{m}\right)}\left\{u_{d s 2}-R_{s} i_{d s 2}-s\left(L_{l m}+L_{m}\right) i_{d s 1}-\right. \\
& \left.-s L_{m} i_{d r}+\omega_{e}\left[\left(L_{l s}+L_{l m}+L_{m}\right) i_{q s 2}+\left(L_{l m}+L_{m}\right) i_{q s 1}+L_{m} i_{q r}\right]\right\}, \\
& i_{q r}=\frac{1}{s} \frac{1}{L_{l r}+L_{m}}\left\{u_{q r}-R_{r} i_{q r}-s L_{m}\left(i_{q s 1}+i_{q s 2}\right)-\right. \\
& \left.-\left(\omega_{e}-\omega_{r}\right)\left[\left(L_{l r}+L_{m}\right) i_{d r}+L_{m}\left(i_{d s 1}+i_{d s 2}\right)\right]\right\} \text {, } \\
& i_{d r}=\frac{1}{s} \frac{1}{L_{l r}+L_{m}}\left\{u_{d r}-R_{r} i_{d r}-s L_{m}\left(i_{d s 1}+i_{d s 2}\right)+\right. \\
& \left.+\left(\omega_{e}-\omega_{r}\right)\left[\left(L_{l r}+L_{m}\right) i_{q r}+L_{m}\left(i_{q s 1}+i_{q s 2}\right)\right]\right\} \text {. }
\end{aligned}
$$

Šešiafazio asinchroninio variklio imitacinis modelis pagal variklio statoriaus ir rotoriaus srovių išraiškas sudaromas remiantis (2.1) lygčių sistema ir (1.8), (1.9) lygtimis. Jị sudaro pereinamujų vyksmų statoriaus grandinejje modelis, rotoriaus grandinès modelis ir momento skaičiavimo modelis. 


\section{Pereinamujų vyksmų statoriaus grandinèje modelis}

Šešiafazio asinchroninio variklio pereinamuju vyksmų statoriaus grandinèje modelis sudaromas remiantis (2.1) lygčių sistemos pirma, antra, trečia ir ketvirta lygtimis. Pagal (2.1) lygčiu sistemos pirmają lygtị gaunamas statoriaus srovès projekcijos $q$ ašyje $i_{q s 1}$ skaičiavimo modelis, kuris pateiktas 2.1 paveiksle.

$$
\begin{aligned}
\omega_{e}\left[\left(L_{l s}+L_{l m}+L_{m}\right) i_{d s 1}+\stackrel{u_{q s 1}}{R_{s} i_{q s}}\right. \\
\left.+\left(L_{l m}+L_{m}\right) i_{d s 2}+L_{m} i_{d r}\right]
\end{aligned}
$$

2.1 pav. Statoriaus srovès projekcijos $q$ ašyje $i_{q s 1}$ skaičiavimo modelis

Fig. 2.1. Computational model of stator current $i_{q s 1}$ aligned to $q$ axis

Srovès $i_{q s 1}$ projekcijos $q$ ašyje skaičiavimo modeli sudaro sumatorius, daugybos blokas ir integratorius. Sumatoriuje sumuojami penki demenys: $u_{q s 1}$, $-R_{s} i_{q s 1}, \quad-\omega_{e}\left[\left(L_{l s}+L_{l m}+L_{m}\right) i_{d s 1}+\left(L_{l m}+L_{m}\right) i_{d s 2}+L_{m} i_{d r}\right],-\left(L_{l m}+L_{m}\right) \frac{d i_{q s 2}}{d t}$ ir $-L_{m} \frac{d i_{q r}}{d t}$. Ju suma dauginama iš antrajame bloke esančios išraiškos $\frac{1}{L_{l s}+L_{l m}+L_{m}}$ ir gaunama išvestinès $\frac{d i_{q s 1}}{d t}$ vertè. Ją suintegravus integravimo bloke gaunama statoriaus srovès projekcijos $q$ ašyje $i_{q s 1}$ reikšmè.

Sudaromas (2.1) lygčių sistemos pirmosios lygties modelis, kuris pateiktas 2.2 paveiksle. İ sumatoriaus antraji ièjimą turi būti siunčiama $-R_{s} i_{q s 1}$ signalas, kurią galima gauti $i_{q s 1}$ padauginus iš $R_{s}$ imant šią sandaugą su neigiamu ženklu. Perduodamas itampas toliau vadinsime signalais. I trečiaji sumatoriaus ièjimą siunčiamas signalas $-\omega_{e}\left[\left(L_{l s}+L_{l m}+L_{m}\right) i_{d s 1}+\left(L_{l m}+L_{m}\right) i_{d s 2}+L_{m} i_{d r}\right]$, gaunamas triju ièjimy sumatoriuje susumavus $\left(L_{l s}+L_{l m}+L_{m}\right) i_{d s 1}$, $\left(L_{l m}+L_{m}\right) i_{d s 2}$ ir $L_{m} i_{d r}$, daugybos bloke gaunamą rezultatą padauginus iš $\omega_{e}$ ir 
imant su neigiamu ženklu. Likusi modelio dalis yra srovės projekcijos $q$ ašyje $i_{q s 1}$ skaičiavimo modelis.

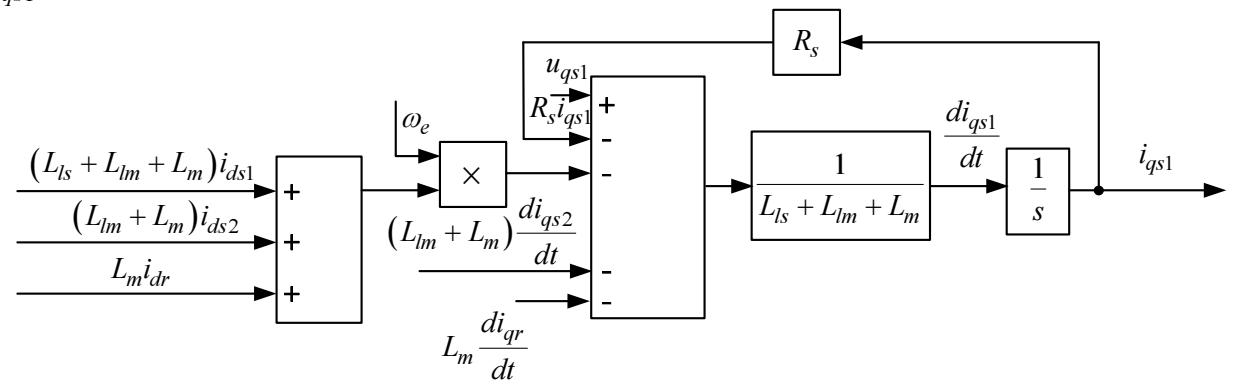

2.2 pav. Lygčių sistemos (2.1) pirmosios lygties skaičiavimo modelis

Fig. 2.2. Computational model of the first equation of the set of equation (2.1)

Pagal (2.1) lygčiu sistemos antrają lygti gaunamas statoriaus srovès projekcijos $q$ ašyje $i_{q s 2}$ skaičiavimo modelis, kuris pateiktas 2.3 paveiksle.

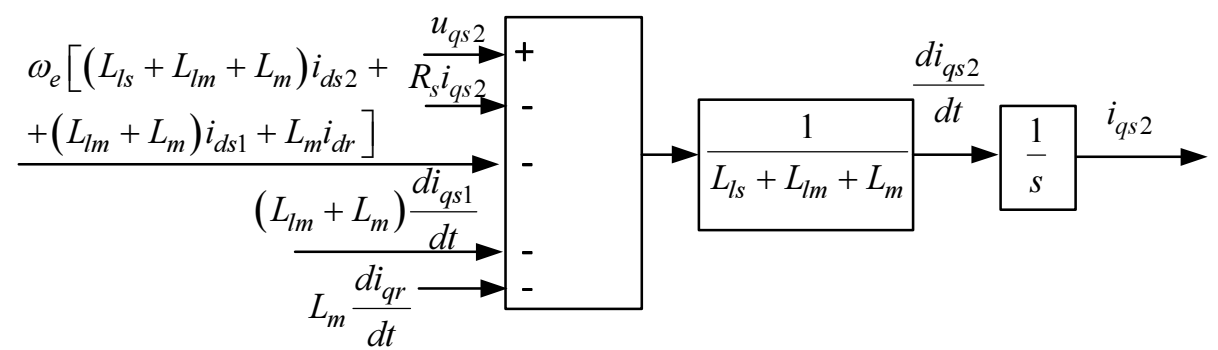

2.3 pav. Statoriaus srovès projekcijos $q$ ašyje $i_{q s 2}$ skaičiavimo modelis

Fig. 2.3. Computational model of stator current $i_{q s 2}$ aligned to $q$ axis

Iš 2.3 paveikslo matyti, kad statoriaus srovès projekcijos $q$ ašyje $i_{q s 2}$ skaičiavimo modeli, sudaro sumatorius, daugybos blokas ir integratorius. Sumatoriuje sumuojami penki demenys: $u_{q s 2}, \quad-R_{s} i_{q s 2}$, $-\omega_{e}\left[\left(L_{l s}+L_{l m}+L_{m}\right) i_{d s 2}+\left(L_{l m}+L_{m}\right) i_{d s 1}+L_{m} i_{d r}\right],-\left(L_{l m}+L_{m}\right) \frac{d i_{q s 1}}{d t} \quad$ ir $-L_{m} \frac{d i_{q r}}{d t}$. Jų suma dauginama iš antrame bloke esančios išraiškos 
$\frac{1}{L_{l s}+L_{l m}+L_{m}}$ ir gaunama išvestinès $\frac{d i_{q s 2}}{d t}$ vertè. Ją suintegravus integravimo bloke gaunama statoriaus srovès projekcijos $q$ ašyje $i_{q s 2}$ vertè.

Sudaromas (2.1) lygčiu sistemos antrosios lygties modelis, kuris pateiktas 2.4 paveiksle. I sumatoriaus antraji ièjima turi būti siunčiamas $-R_{s} i_{q s 2}$ signalas, kuri galima gauti išèjimo signalą $i_{q s 2}$ padauginus iš $R_{s}$ imant šią sandaugą su neigiamu ženklu. I trečiaji sumatoriaus iejjimą siunčiamas signalas $-\omega_{e}\left[\left(L_{l s}+L_{l m}+L_{m}\right) i_{d s 2}+\left(L_{l m}+L_{m}\right) i_{d s 1}+L_{m} i_{d r}\right]$, gaunamas trijų iejjimų sumatoriuje susumavus tris signalus $\left(L_{l s}+L_{l m}+L_{m}\right) i_{d s 2},\left(L_{l m}+L_{m}\right) i_{d s 1}$ ir $L_{m} i_{d r}$, daugybos bloke gaunamą sumini signalą padauginus iš $\omega_{e}$ ir imant rezultatą su neigiamu ženklu. Likusi modelio dalis yra srovės projekcijos $q$ ašyje $i_{q s 2}$ skaičiavimo modelis.

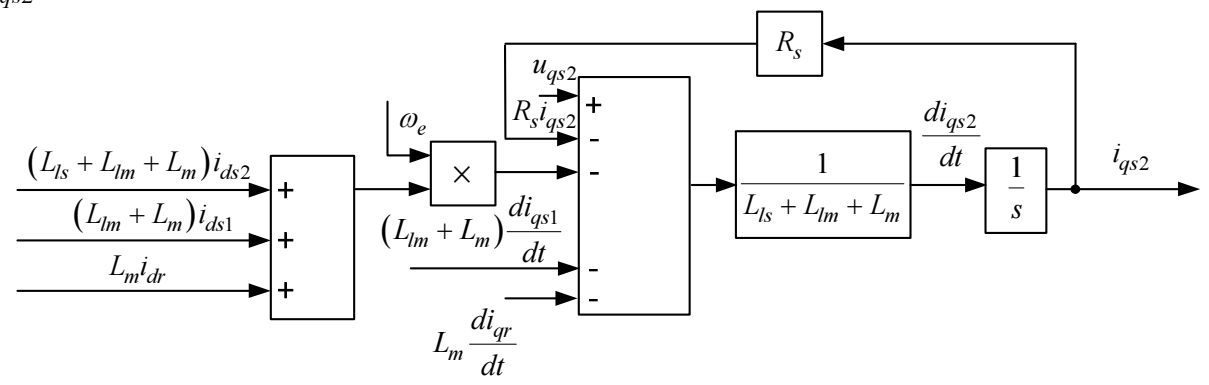

2.4 pav. Lygčiu sistemos (2.1) antrosios lygties skaičiavimo modelis

Fig. 2.4. Computational model of the second equation of the set of equation (2.1)

Pagal (2.1) lygčių sistemos trečiają lygti gaunamas statoriaus srovès projekcijos $d$ ašyje $i_{d s 1}$ skaičiavimo modelis, kuris pateiktas 2.5 paveiksle. Statoriaus srovés projekcijos $d$ ašyje $i_{d s 1}$ skaičiavimo modelị sudaro sumatorius, daugybos blokas ir integratorius. Sumatoriuje sumuojami penki dèmenys: $u_{d s 1}$, $-R_{s} i_{d s 1}, \omega_{e}\left[\left(L_{l s}+L_{l m}+L_{m}\right) i_{q s 1}+\left(L_{l m}+L_{m}\right) i_{q s 2}+L_{m} i_{q r}\right],-\left(L_{l m}+L_{m}\right) \frac{d i_{d s 2}}{d t}$ ir $-L_{m} \frac{d i_{d r}}{d t}$. Jų suma dauginama iš antrajame bloke esančios išraiškos $\frac{1}{L_{l s}+L_{l m}+L_{m}}$ ir gaunama išvestinès $\frac{d i_{d s 1}}{d t}$ vertè. Ją suintegravus integravimo bloke gaunama statoriaus srovès projekcijos $d$ ašyje $i_{d s 1}$ vertè. 


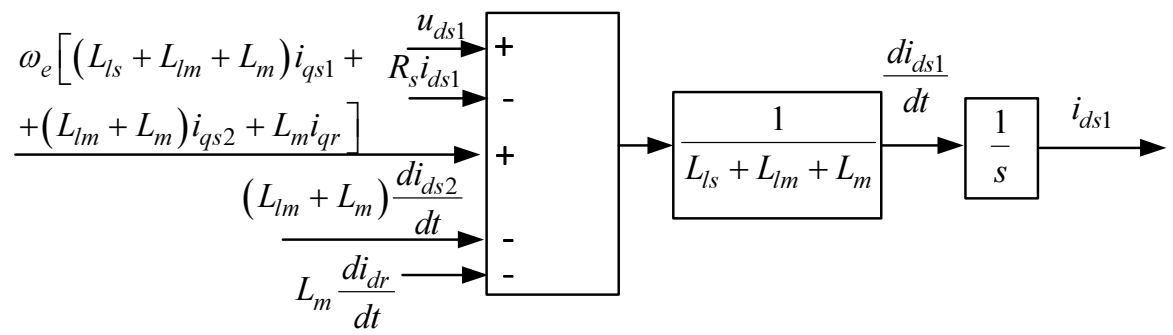

2.5 pav. Statoriaus srovès projekcijos $d$ ašyje $i_{d s 1}$ skaičiavimo modelis

Fig. 2.5. Computational model of stator current $i_{d s 1}$ aligned to $d$ axis

2.6 paveiksle pateiktas (2.1) lygčių sistemos trečiosios lygties skaičiavimo modelis.

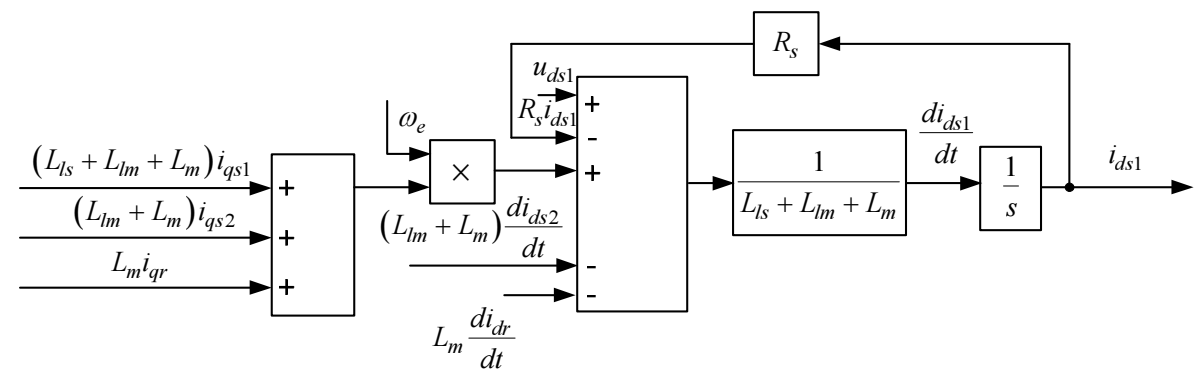

2.6 pav. Lygčių sistemos (2.1) trečiosios lygties skaičiavimo modelis

Fig. 2.6. Computational model of the third equation of the set of equation (2.1)

2.6 paveiksle pateiktą (2.1) lygčiu sistemos trečiosios lygties skaičiavimo modeli sudaro trijų signalu sumatorius, trys daugybos blokai, penkių signalų sumatorius ir integravimo blokas. I penkių signalų sumatoriaus antraji iejjima turi būti siunčiamas signalas $-R_{s} i_{d s 1}$, kuris gaunamas išèjimo signalą $i_{d s 1}$ padauginus iš $R_{S}$ imant šią sandaugą su neigiamu ženklu. İ trečiąji sumatoriaus ièjimą siunčiamas signalas $\omega_{e}\left[\left(L_{l s}+L_{l m}+L_{m}\right) i_{q s 1}+\left(L_{l m}+L_{m}\right) i_{q s 2}+L_{m} i_{q r}\right]$, gaunamas trijų ièjimų sumatoriuje susumavus tris signalus $\left(L_{l s}+L_{l m}+L_{m}\right) i_{q s 1}$, $\left(L_{l m}+L_{m}\right) i_{q s 2}$ ir $L_{m} i_{q r}$, daugybos bloke gaunamą suminị signalą padauginus iš $\omega_{e}$. Likusi modelio dalis yra srovès projekcijos $d$ ašyje $i_{d s 1}$ skaičiavimo modelis.

Pagal (2.1) lygčių sistemos ketvirtają lygti gaunamas statoriaus srovès projekcijos $d$ ašyje $i_{d s 2}$ skaičiavimo modelis, kuris pateiktas 2.7 paveiksle. Jị sudaro sumatorius, sandaugos blokas ir integratorius. Sumatoriuje sumuojami 
penki dèmenys: $\quad u_{d s 2}, \quad-R_{s} i_{d s 2}, \quad-\left(L_{l m}+L_{m}\right) \frac{d i_{d s 1}}{d t}, \quad-L_{m} \frac{d i_{d r}}{d t} \quad$ ir $\omega_{e}\left[\left(L_{l s}+L_{l m}+L_{m}\right) i_{q s 2}+\left(L_{l m}+L_{m}\right) i_{q s 1}+L_{m} i_{q r}\right]$. Jų suma dauginama iš antrajame bloke esančios išraiškos $\frac{1}{L_{l s}+L_{l m}+L_{m}}$ ir gaunama išvestinès $\frac{d i_{d s}}{d t}$ vertè. Ją suintegravus integravimo bloke gaunama statoriaus srovès projekcijos $d$ ašyje $i_{d s 2}$ vertè.

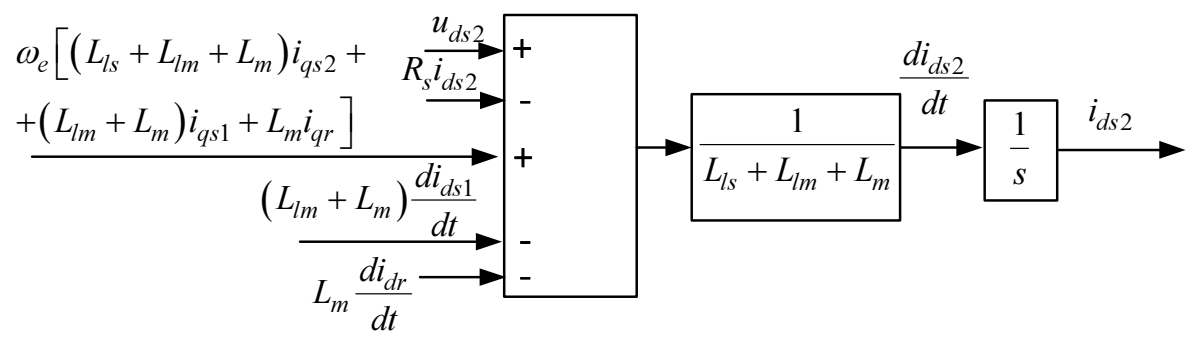

2.7 pav. Statoriaus srovès projekcijos $d$ ašyje $i_{d s 2}$ skaičiavimo modelis

Fig. 2.7. Computational model of stator current $i_{d s 2}$ aligned to $d$ axis

2.8 paveiksle pateiktas (2.1) lygčių sistemos ketvirtosios lygties skaičiavimo modelis.

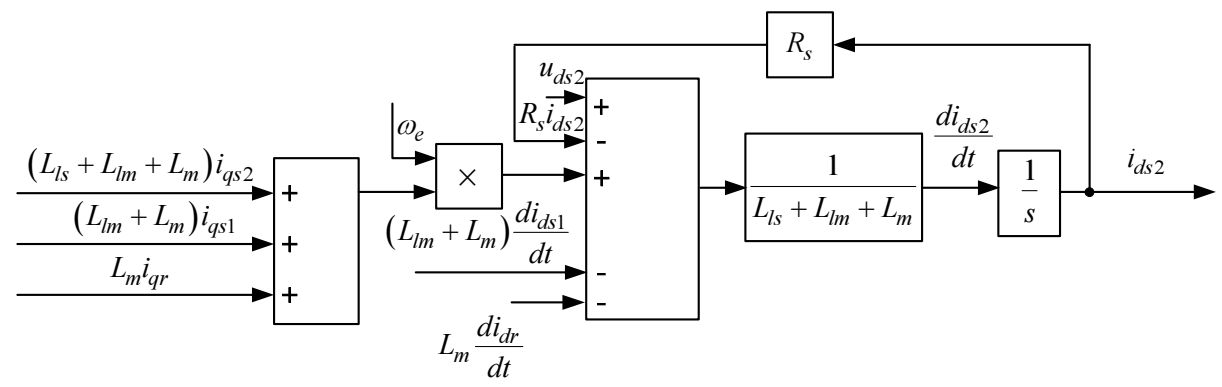

2.8 pav. Lygčių sistemos (2.1) ketvirtosios lygties skaičiavimo modelis

Fig. 2.8. Computational model of the fourth equation of the set of equation (2.1)

(2.1) lygčiu sistemos ketvirtosios lygties skaičiavimo modelị sudaro trijų signalu sumatorius, trys daugybos blokai, penkių signalu sumatorius ir integravimo blokas. I penkių signalų sumatoriaus antrajj ịejima turi būti 
siunčiamas signalas $-R_{s} i_{d s 2}$, kuris gaunamas išejimo signalą $i_{d s 2}$ padauginus iš $R_{s}$ imant šią sandaugą su neigiamu ženklu. I trečiajji sumatoriaus iejjimą siunčiamas signalas $\quad \omega_{e}\left[\left(L_{l s}+L_{l m}+L_{m}\right) i_{q s 2}+\left(L_{l m}+L_{m}\right) i_{q s 1}+L_{m} i_{q r}\right]$, gaunamas trijų iejjimų sumatoriuje susumavus tris signalus $\left(L_{l s}+L_{l m}+L_{m}\right) i_{q s 2}$, $\left(L_{l m}+L_{m}\right) i_{q s 1}$ ir $L_{m} i_{q r}$, daugybos bloke gaunamą sumini signalą padauginus iš $\omega_{e}$. Likusi modelio dalis yra srovès projekcijos $d$ ašyje $i_{d s 2}$ skaičiavimo modelis.

Pirmos keturios lygčiu sistemos (2.1) lygtys aprašo elektromagnetinius vyksmus šešiafazio asinchroninio variklio statoriuje. Susiejus šių lygčių skaičiavimo modelius, parodytus $2.2,2.4,2.6$ ir 2.8 paveiksluose ir ijungus papildomus blokus gaunamas šešiafazio asinchroninio variklio statoriaus pereinamujų vyksmų modelis, kuris pavaizduotas 2.9 paveiksle.

Šešiafazio asinchroninio variklio statoriaus pereinamujų vyksmų modeliui sudaryti prie (2.1) lygčių sistemos pirmosios ir antrosios lygčių skaičiavimo modelių penkių signalų sumatorių pirmųjų iejjimų prijungiama ịtampa, kurią tiekia step1" blokas. Kampinis sukimosi greitis $\omega_{e}$ modeliuojamas bloke „step2“ ir siunčiamas i (2.1) lygčių sistemos pirmosios, antrosios, trečiosios ir ketvirtosios lygčiu skaičiavimo modelių daugybos blokus, pažymètus , $\mathrm{X}^{“}$.

\section{Rotoriaus grandinès modelis}

Šešiafazio asinchroninio variklio rotorio grandinès modelis sudaromas remiantis (2.1) lygčių sistemos penkta ir šešta lygtimis. Pagal (2.1) lygčių sistemos penktają lygti gaunamas rotoriaus srovès projekcijos $q$ ašyje $i_{q r}$ skaičiavimo modelis, kuris pateiktas 2.10 paveiksle. Jị sudaro sumatorius, daugybos blokas ir integratorius. Sumatoriuje sumuojami penki demenys: $u_{q r},-R_{r} i_{q r}$, $-\left(\omega_{e}-\omega_{r}\right)\left[\left(L_{l r}+L_{m}\right) i_{d r}+L_{m}\left(i_{d s 1}+i_{d s 2}\right)\right],-L_{m} \frac{d i_{q s 1}}{d t}$ ir $-L_{m} \frac{d i_{q s 2}}{d t}$. Jų suma dauginama iš antrame bloke esančios išraiškos $\frac{1}{L_{l r}+L_{m}}$ ir gaunama išvestinès $\frac{d i_{q r}}{d t}$ verte. Ją suintegravus integravimo bloke gaunama rotoriaus srovès projekcijos $q$ ašyje $i_{q r}$ verte. 


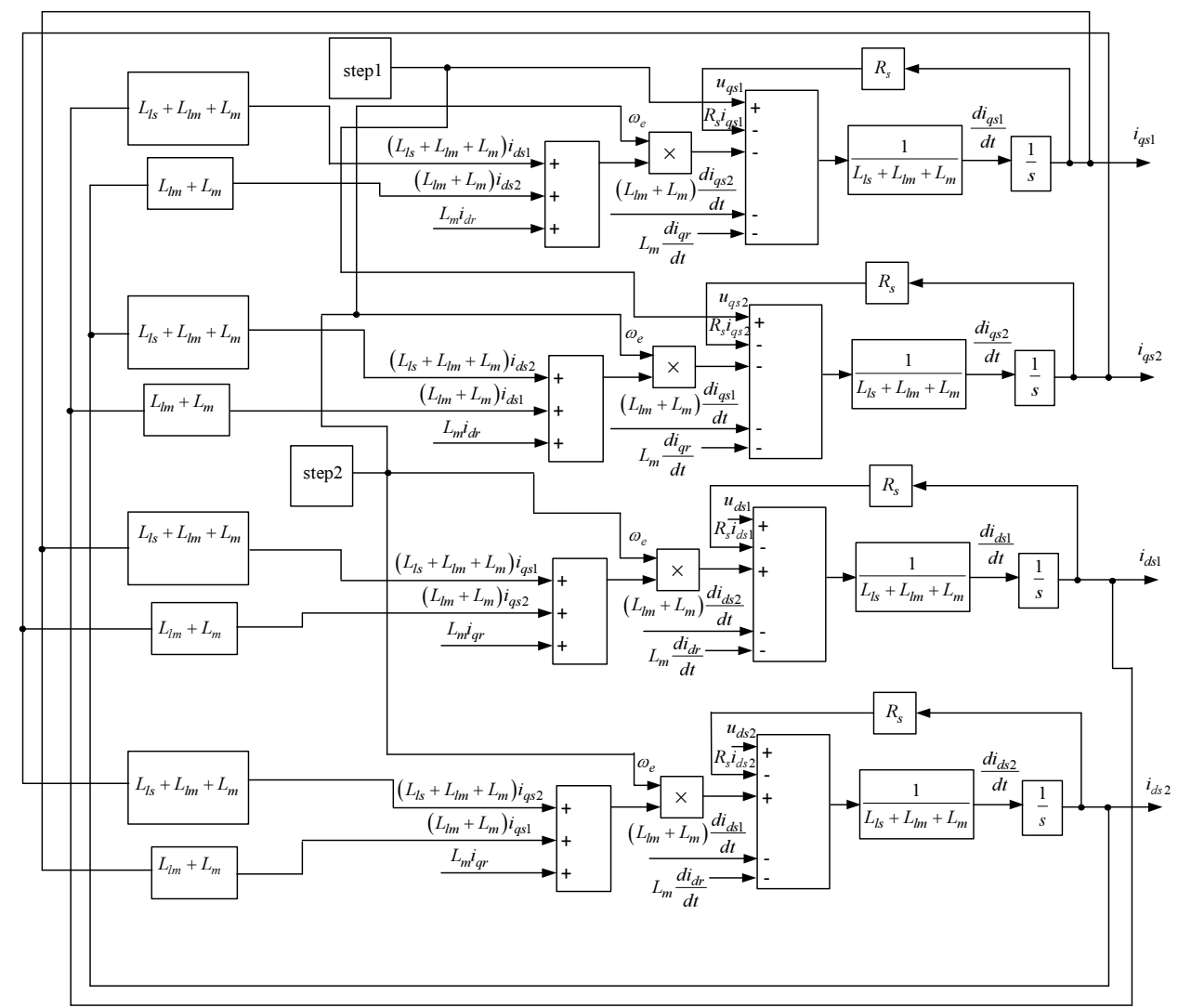

2.9 pav. Šešiafazio asinchroninio variklio statoriaus kompiuterinis modelis

Fig. 2.9. Computational stator model of six phase induction motor

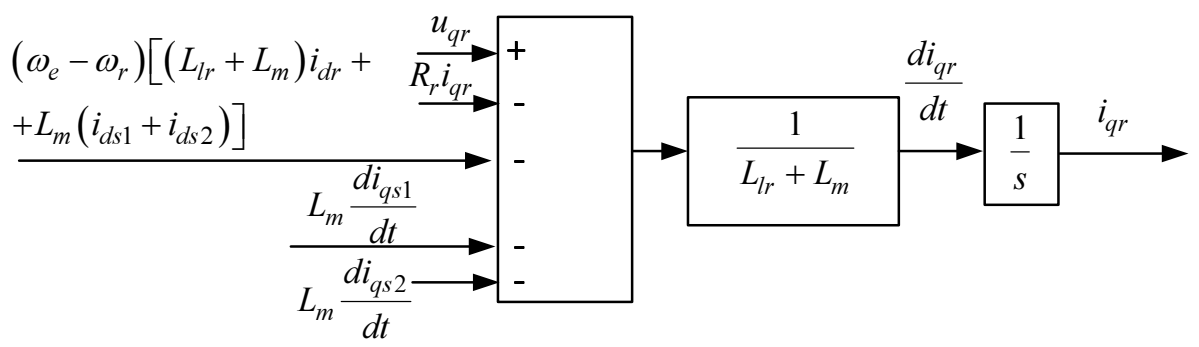

2.10 pav. Rotoriaus srovès projekcijos $q$ ašyje $i_{q r}$ modelis

Fig. 2.10. Computational model of rotor current $i_{q r}$ aligned to $q$ axis 
Sudaromas (2.1) lygčių sistemos penktosios lygties skaičiavimo modelis, kuris pateiktas 2.11 paveiksle. I penkių signalų sumatoriaus antrajj iejjimą turi būti siunčiamas $-R_{r} i_{q r}$ signalas, kurị galima gauti išèjimo signalą $i_{q r}$ padauginus iš $R_{r}$ imant šią sandaugą su neigiamu ženklu. I trečiajj šio sumatoriaus siunčiamas signalas $-\left(\omega_{e}-\omega_{r}\right)\left[\left(L_{l r}+L_{m}\right) i_{d r}+L_{m}\left(i_{d s 1}+i_{d s 2}\right)\right], \quad$ gaunamas keturių iejjimų sumatoriuje susumavus keturis signalus $L_{l r} i_{d r}, L_{m} i_{d r}, L_{m} i_{d s 1}$ ir $L_{m} i_{d s 2}$, daugybos bloke gaunamą sumini signalą padauginus iš $\omega_{e}-\omega_{r}$ ir imant rezultatą su neigiamu ženklu. Likusi modelio dalis yra srovės projekcijos $q$ ašyje $i_{q r}$ skaičiavimo modelis.

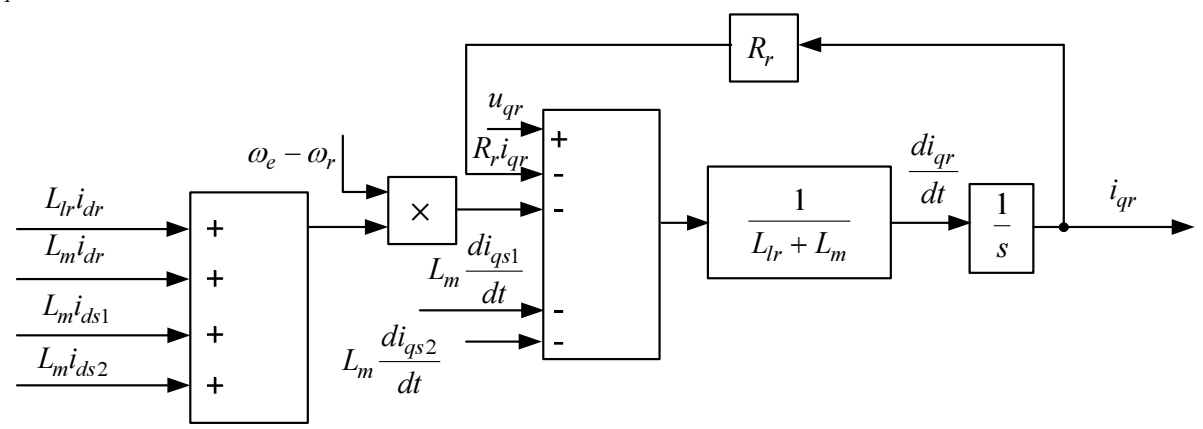

2.11 pav. Lygčiu sistemos (2.1) penktosios lygties skaičiavimo modelis

Fig. 2.11. Computational model of the fifth equation of the set of equation (2.1)

Pagal (2.1) lygčiu sistemos šeštają lygti gaunamas rotoriaus srovès projekcijos $d$ ašyje $i_{d r}$ skaičiavimo modelis, kuris pateiktas 2.12 paveiksle. Jị sudaro sumatorius, daugybos blokas ir integratorius. Sumatoriuje sumuojami penki dèmenys: $u_{d r}, \quad-R_{r} i_{d r}, \quad\left(\omega_{e}-\omega_{r}\right)\left[\left(L_{l r}+L_{m}\right) i_{q r}+L_{m}\left(i_{q s 1}+i_{q s 2}\right)\right]$, $-L_{m} \frac{d i_{d s 1}}{d t}$ ir $-L_{m} \frac{i_{d s 2}}{d t}$. Jų suma dauginama iš antrame bloke esančios išraiškos $\frac{1}{L_{l r}+L_{m}}$ ir gaunama išvestinès $\frac{d i_{d r}}{d t}$ vertè. Ją suintegravus integravimo bloke gaunama srovès projekcijos $d$ ašyje $i_{d r}$ vertè. 


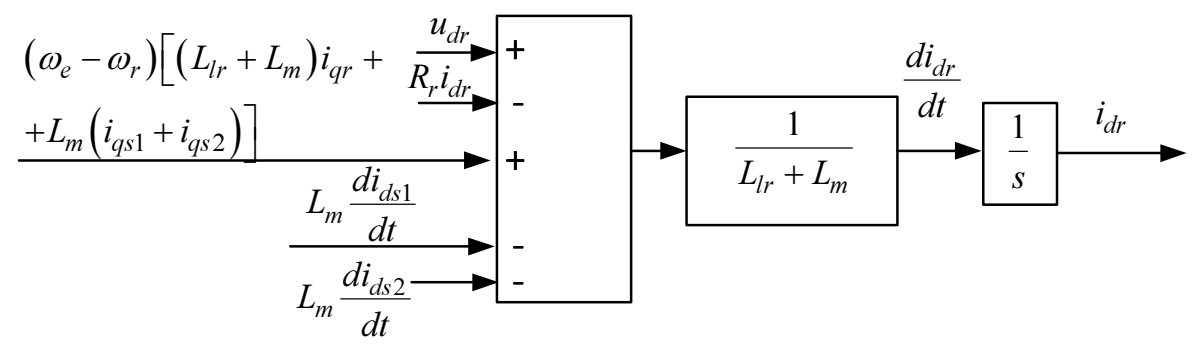

2.12 pav. Rotoriaus srovès projekcijos $d$ ašyje $i_{d r}$ skaičiavimo modelis

Fig. 2.12. Computational model of rotor current $i_{d r}$ aligned to $d$ axis

Sudaromas (2.1) lygčiu sistemos šeštosios lygties skaičiavimo modelis, kuris pateiktas 2.13 paveiksle. I penkių signalų sumatoriaus antraji iejjima turi būti siunčiamas $-R_{r} i_{d r}$ signalas, kurị galima gauti išèjimo signalą $i_{d r}$ padauginus iš $R_{r}$ imant šią sandaugą su neigiamu ženklu. I trečiaji šio sumatoriaus siunčiamas signalas $\left(\omega_{e}-\omega_{r}\right)\left[\left(L_{l r}+L_{m}\right) i_{q r}+L_{m}\left(i_{q s 1}+i_{q s 2}\right)\right]$, gaunamas keturių ièjimų sumatoriuje susumavus keturis signalus $L_{l r} i_{q r}, L_{m} i_{q r}, L_{m} i_{q s 1}$ ir $L_{m} i_{q s 2}$, daugybos bloke gaunamą sumini signalą padauginus iš $\omega_{e}-\omega_{r}$. Likusi modelio dalis yra rotoriaus srovès projekcijos $d$ ašyje $i_{d r}$ skaičiavimo modelis.

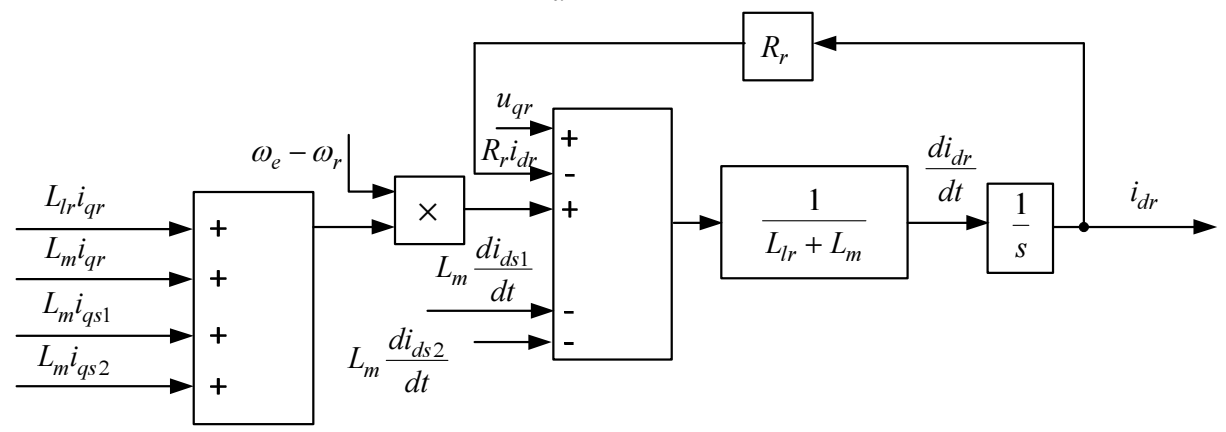

2.13 pav. Lygčių sistemos (2.1) šeštos lygties skaičiavimo modelis

Fig. 2.13. Computational model of the sixth equation of the set of equation (2.1) 
Susiejus lygčių modelius, parodytus 2.11 ir 2.13 paveiksluose gaunamas šešiafazio asinchroninio variklio rotoriaus grandinès modelis, kuris pavaizduotas 2.14 paveiksle.

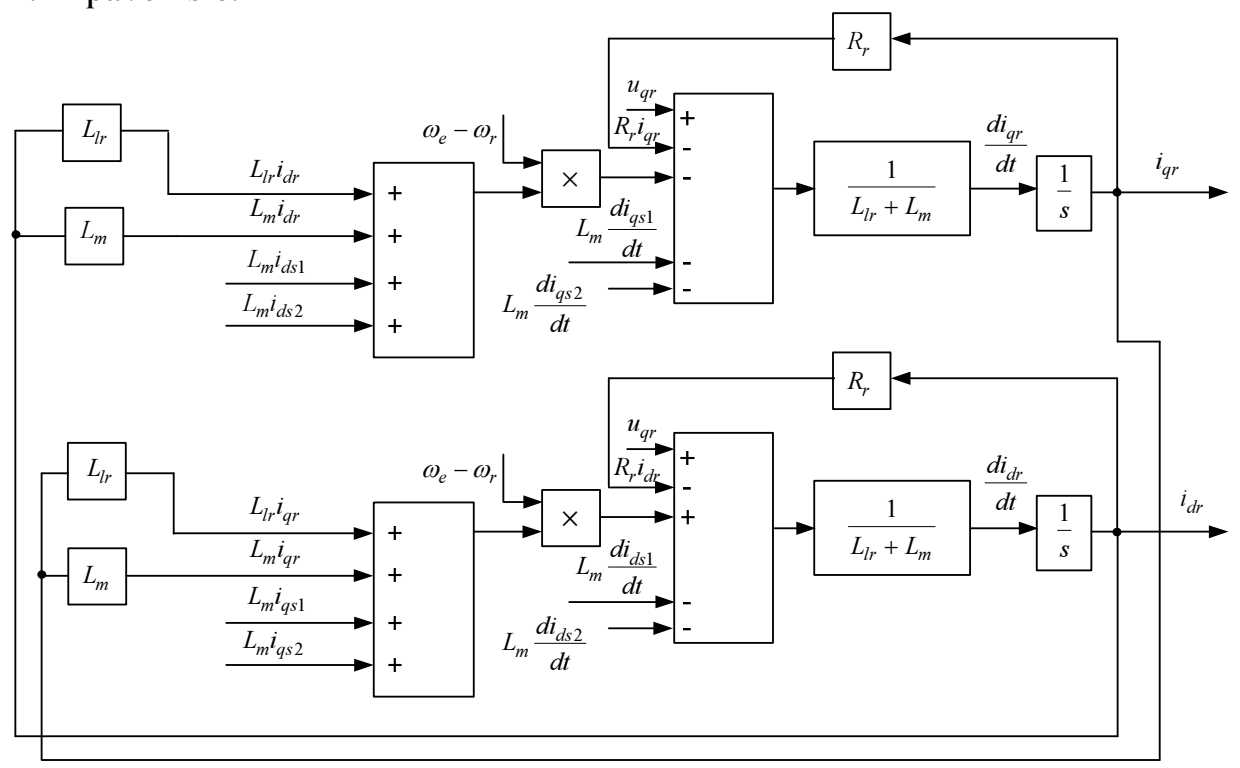

2.14 pav. Šešiafazio asinchroninio variklio rotoriaus grandinès modelis

Fig. 2.14. Computational rotor model of six phase induction motor

\section{Momento skaičiavimo modelis}

Sudaromas $\Psi_{q r}$ lygties skaičiavimo modelis, kuris pateiktas 2.15 paveiksle. Pirmajame dviejų signalų sumatoriuje sumuojamos dvi srovès $i_{q s 1}$ ir $i_{q s 2}$. Jų suma antrajame sumatoriuje sumuojama su dar viena srove $i_{q r}$. Gautas rezultatas yra sudauginamas su $L_{m}$ ir paskutiniame sumatoriuje sudedamas su sandauga $L_{l r} i_{q r}$. Sumatoriaus išejime gaunamas srautas $\Psi_{q r}$.

Analogiškai sudaromas $\Psi_{d r}$ lygties skaičiavimo modelis, kuris pateiktas 2.16 paveiksle. Pirmajame dviejų signalų sumatoriuje sumuojamos dvi srovès $i_{d s 1}$ ir $i_{d s 2}$. Jų suma antrajame sumatoriuje sumuojama su dar viena srove $i_{d r}$. 
Gautas rezultatas yra sudauginamas su $L_{m}$ ir paskutiniame sumatoriuje sudedamas su sandauga $L_{l r} i_{d r}$. Sumatoriaus išejjime gaunamas srautas $\Psi_{d r}$.

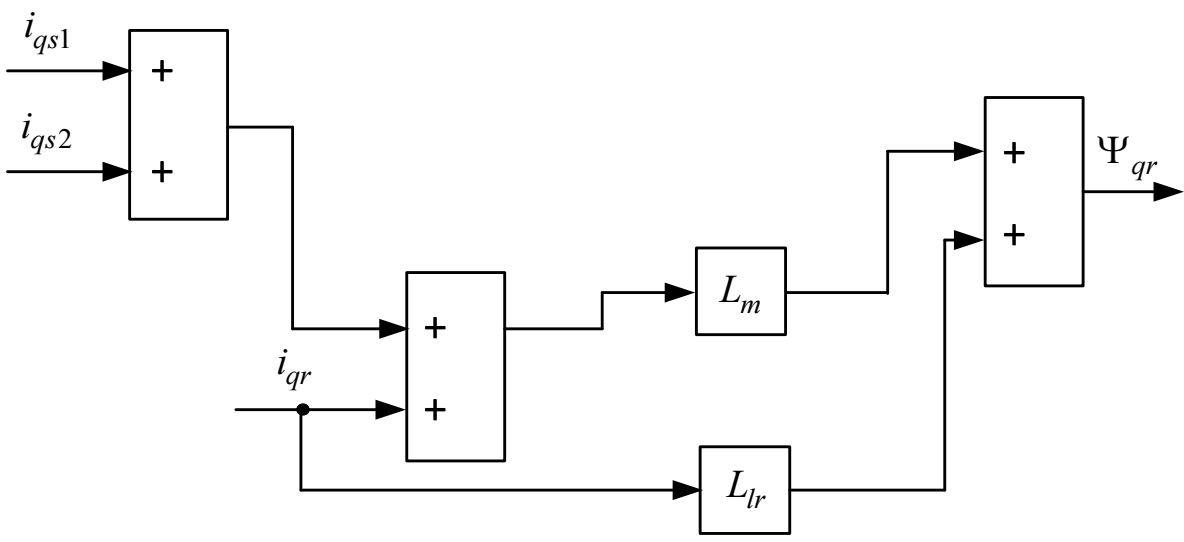

2.15 pav. Lygties $\Psi_{q r}$ skaičiavimo modelis

Fig. 2.15. Computational model of $\Psi_{q r}$ equation

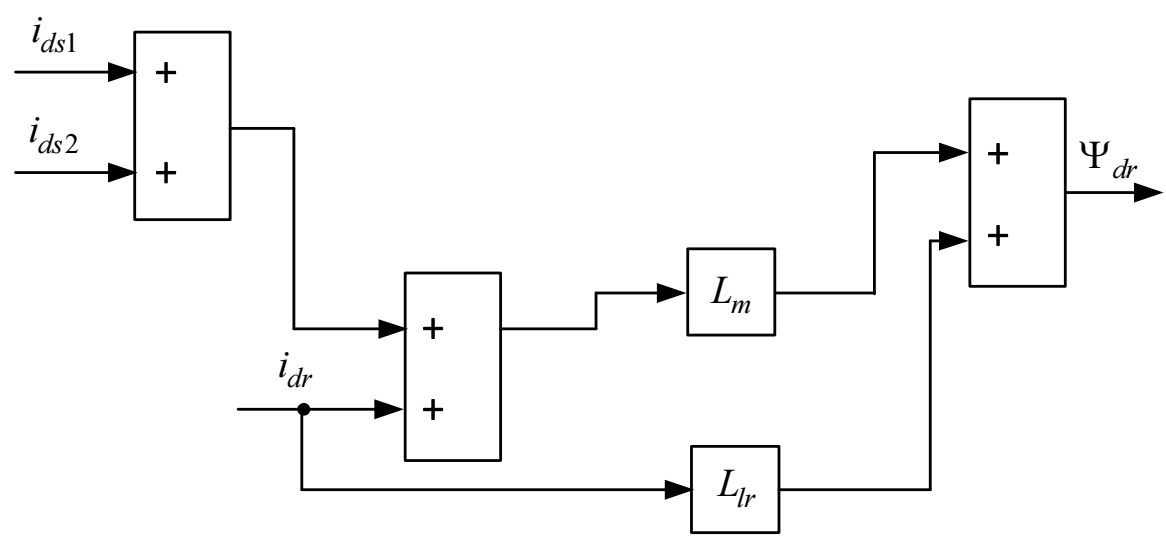

2.16 pav. Lygties $\Psi_{d r}$ skaičiavimo modelis

Fig. 2.16. Computational model of $\Psi_{d r}$ equation

Momento skaičiavimo modelis sudaromas pagal (1.8) lygtị. Modelis gaunamas apjungiant 2.15. ir 2.16 paveiksluose pateiktus lygčių $\Psi_{q r}$ ir $\Psi_{d r}$ 
modelius ir ijungiant papildomus blokus. Sudarytas momento skaičiavimo modelis pateiktas 2.17 paveiksle.

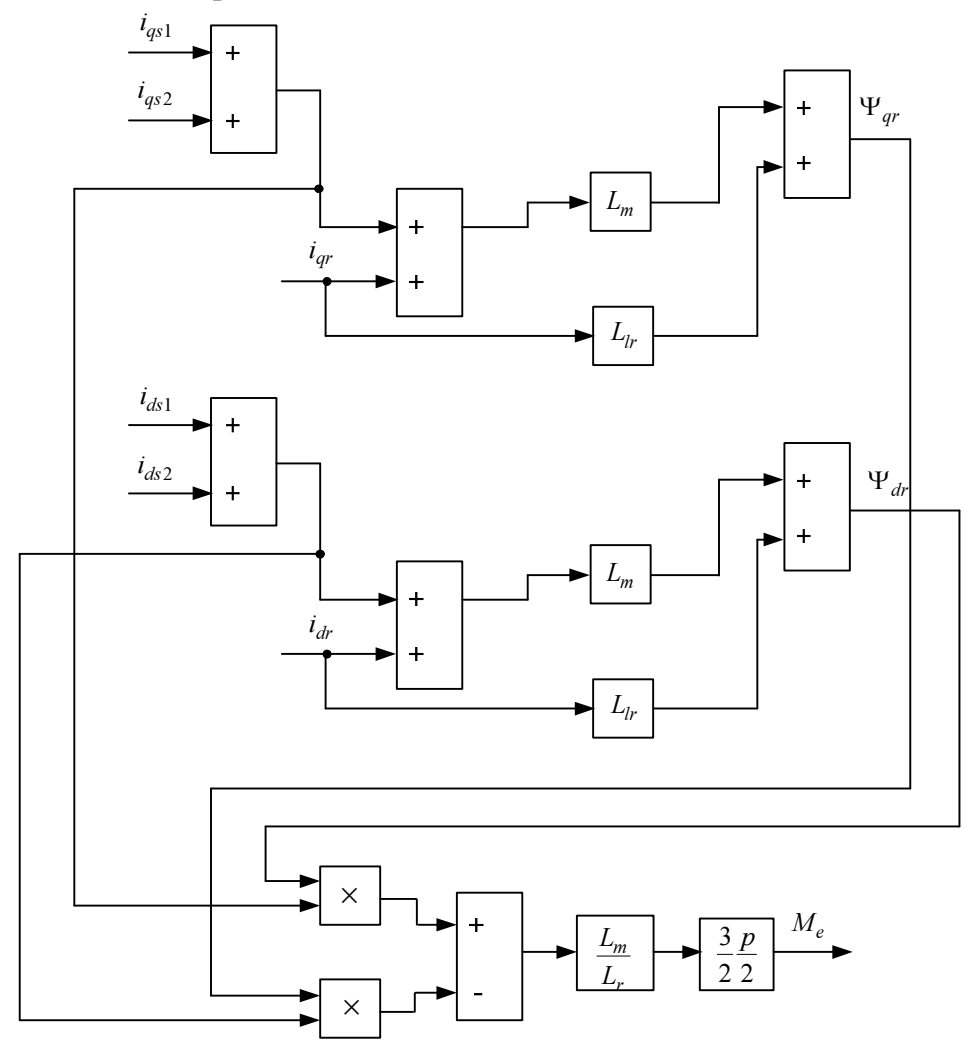

2.17 pav. Variklio momento skaičiavimo modelis

Fig. 2.17. Computational model of motor torque

Pirmajame daugybos bloke sudauginami signalai $i_{q s 1}, i_{q s 2}$ ir 2.16 paveiksle pateikto lygties $\Psi_{d r}$ skaičiavimo modelio išejimo signalas. Antrajame daugybos bloke sudauginami signalai $i_{d s 1}, i_{d s 2}$ ir 2.15 paveiksle pateikto lygties $\Psi_{q r}$ skaičiavimo modelio išèjimo signalas. Pirmojo daugybos bloko išèjimo signalas yra sumuojamas su antrojo daugybos bloko išèjimo signalu, imant ji su neigiamu ženklu. Suminis signalas dauginamas iš santykio $\frac{L_{m}}{L_{r}}$ ir dar kartą dauginamas iš santykio $\frac{3}{2} \frac{P}{2}$. Išejime gaunamas variklio momentas. 


\section{2. Šešiafazio asinchroninio variklio modelio sudarymas pagal srautų išraiškas}

Šešiafazio asinchrononio variklio statoriaus ir rotoriaus srautų išraiškos užrašytos sinchroniniu greičiu besisukančioje koordinačių sistemoje:

$$
\begin{aligned}
& \Psi_{q s 1}=\left(L_{l s}+L_{l m}+L_{m}\right) i_{q s 1}+\left(L_{l m}+L_{m}\right) i_{q s 2}+L_{m} i_{q r}, \\
& \Psi_{q s 2}=\left(L_{l s}+L_{l m}+L_{m}\right) i_{q s 2}+\left(L_{l m}+L_{m}\right) i_{q s 1}+L_{m} i_{q r}, \\
& \Psi_{d s 1}=\left(L_{l s}+L_{l m}+L_{m}\right) i_{d s 1}+\left(L_{l m}+L_{m}\right) i_{d s 2}+L_{m} i_{d r}, \\
& \Psi_{d s 2}=\left(L_{l s}+L_{l m}+L_{m}\right) i_{d s 2}+\left(L_{l m}+L_{m}\right) i_{d s 1}+L_{m} i_{d r}, \\
& \Psi_{q r}=\left(L_{l r}+L_{m}\right) i_{q r}+L_{m}\left(i_{q s 1}+i_{q s 2}\right), \\
& \Psi_{d r}=\left(L_{l r}+L_{m}\right) i_{d r}+L_{m}\left(i_{d s 1}+i_{d s 2}\right) .
\end{aligned}
$$

Šešiafazio asinchroninio variklio kompiuterinis modelis pagal variklio statoriaus ir rotoriaus srautu išraiškas sudaromas remiantis (1.4), (1.6), (2.2) lygčiu sistemomis ir (1.8), (1.9) lygtimis. Jis susideda iš pereinamujų vyksmų statoriaus grandineje modelio, rotoriaus grandinès modelio ir momento skaičiavimo modelio.

Šešiafazio asinchroninio variklio pereinamųjų vyksmų statoriaus grandinejje modeliui sudaryti naudojamos pirmos keturios lygčių sistemų (1.4) ir (2.2) lygtys.

Pirmiausia pagal (1.4) lygčių sistemos pirmają lygti gaunamas statoriaus srauto projekcijos $q$ ašyje $\Psi_{q s 1}$ skaičiavimo modelis, kuris pateiktas 2.18 paveiksle.

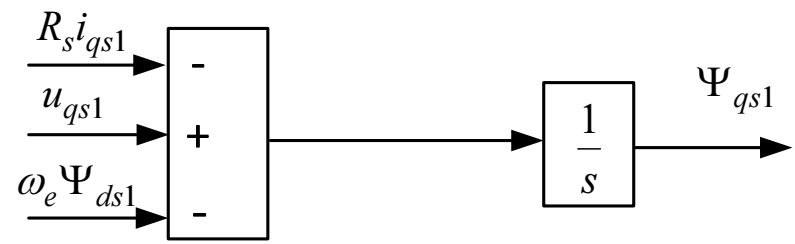

2.18 pav. Statoriaus srauto projekcijos $q$ ašyje $\Psi_{q s 1}$ skaičiavimo modelis

Fig. 2.18. Computational model of stator flux $\Psi_{q s 1}$ aligned to $q$ axis

Statoriaus srauto projekcijos $q$ ašyje $\Psi_{q s 1}$ skaičiavimo modeli sudaro sumatorius ir integratorius. Sumatoriuje sumuojami trys demenys: $-R_{s} i_{q s 1}, u_{q s 1}$ 
ir $-\omega_{e} \Psi_{d s 1}$. Šią sumą suintegravus integravimo bloke gaunama statoriaus srauto projekcijos $q$ ašyje $\Psi_{q s 1}$ vertè.

Analogiškai sudaromas srauto projekcijos $q$ ašyje $\Psi_{q s 2}$ skaičiavimo modelis.

2.19 paveiksle pateiktą statoriaus srauto projekcijos $d$ ašyje $\Psi_{d s 1}$ skaičiavimo modeli sudaro sumatorius ir integratorius. Sumatoriuje sumuojami trys dèmenys: $-R_{s} i_{d s 1}, u_{d s 1}$ ir $\omega_{e} \Psi_{q s 1}$. Šią sumą suintegravus integravimo bloke gaunama statoriaus srauto projekcijos $d$ ašyje $\Psi_{d s 1}$ vertè.

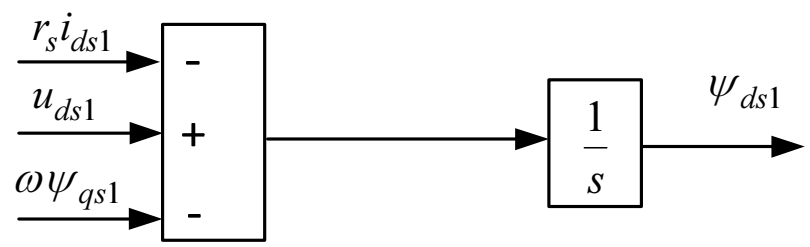

2.19 pav. Statoriaus srauto projekcijos $d$ ašyje $\Psi_{d s 1}$ skaičiavimo modelis

Fig. 2.19. Computational model of stator flux $\Psi_{d s 1}$ aligned to $d$ axis

Statoriaus srauto projekcijos $d$ ašyje $\Psi_{d s 2}$ skaičiavimo modelis, kurị sudaro sumatorius ir integratorius, gaunamas analogiškai srauto projekcijos $d$ ašyje $\Psi_{d s 1}$ skaičiavimo modeliui.

Toliau sudaromas srovès $i_{q s 1}$ projekcijos $q$ ašyje modelis, kuris pateiktas 2.20 paveiksle.

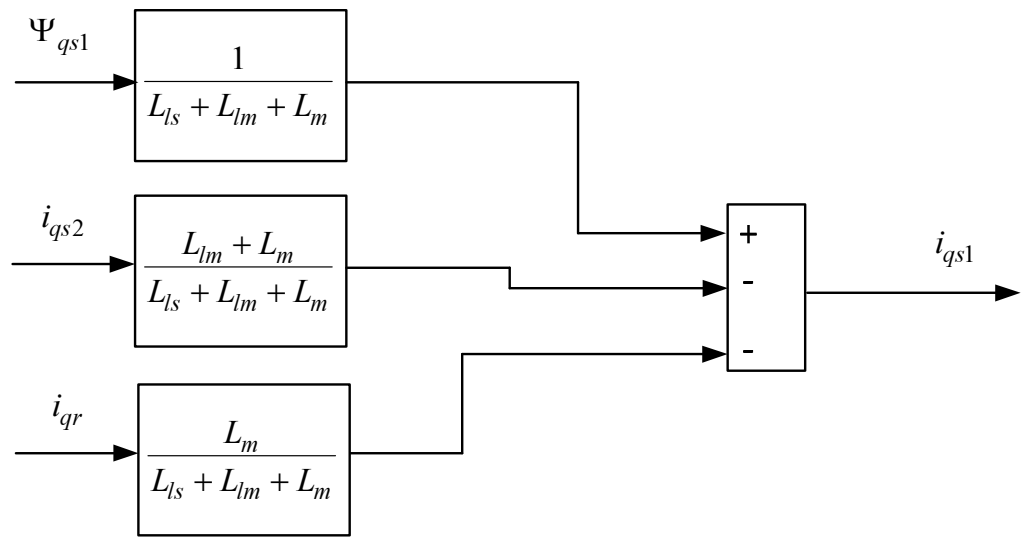

2.20 pav. Statoriaus srovės projekcijos $q$ ašyje $i_{q s 1}$ skaičiavimo modelis

Fig. 2.20. Computational model of stator current $i_{q s 1}$ aligned to $q$ axis 
2.20 paveiksle pateiktame modelyje, srautas $\Psi_{q s 1}$ yra dauginamas iš $\frac{1}{L_{l s}+L_{l m}+L_{m}}$ ir siunčiamas i triju dèmenu sumatorių. Srové $i_{q s 2}$ yra dauginama iš $\frac{L_{l m}+L_{m}}{L_{l s}+L_{l m}+L_{m}}$, o srovè $i_{q r}$ iš $\frac{L_{m}}{L_{l s}+L_{l m}+L_{m}}$ ir šios sandaugos su neigiamais ženklais taip pat siunčiamos i sumatorių. Sumatoriuje sandaugas sudèjus, išèjime yra gaunama srovė $i_{q s 1}$.

Analogiškai gaunamas statoriaus srovès projekcijos $q$ ašyje $i_{q s 2}$ skaičiavimo modelis.

2.21 paveiksle pateiktas statoriaus srovès projekcijos $d$ ašyje $i_{d s 1}$ skaičiavimo modelis, o 2.22 paveiksle šešiafazio asinchroninio variklio pereinamujjų vyksmų modelis.

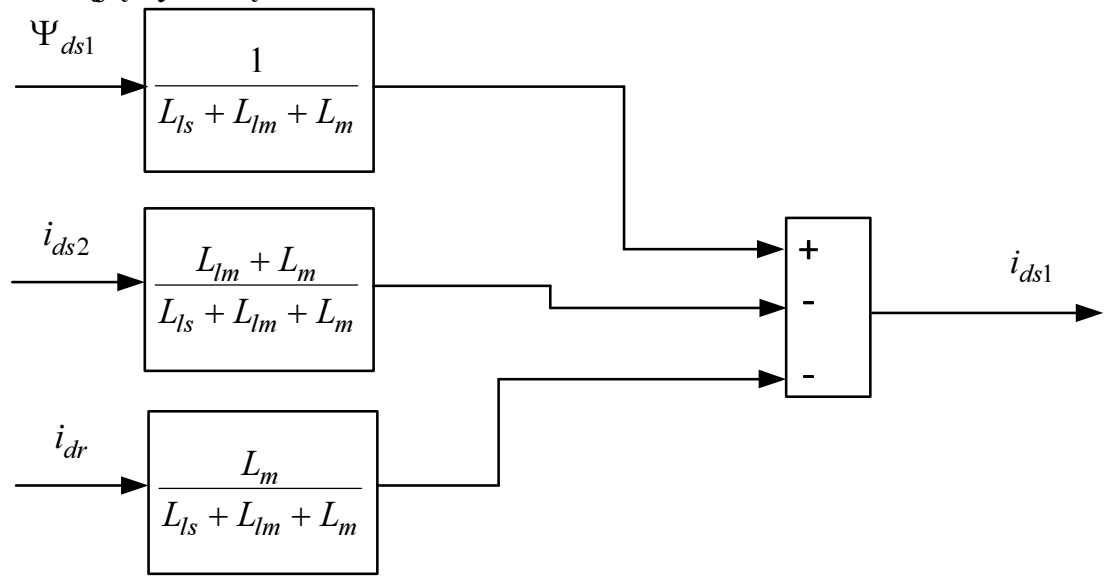

2.20 pav. Statoriaus srovès projekcijos $d$ ašyje $i_{d s 1}$ skaičiavimo modelis

Fig. 2.20. Computational model of stator current $i_{d s 1}$ aligned to $d$ axis

Statoriaus srovès $i_{d s 1}$ skaičiavimo modelyje srautas $\Psi_{d s 1}$ yra dauginamas iš $\frac{1}{L_{l s}+L_{l m}+L_{m}}$ ir siunčiamas i sumatorių. Srovè $i_{d s 2}$ yra dauginama iš $\frac{L_{l m}+L_{m}}{L_{l s}+L_{l m}+L_{m}}$, o srove $i_{d r}$ iš $\frac{L_{m}}{L_{l s}+L_{l m}+L_{m}}$ ir šios sandaugos su neigiamais ženklais taip pat yra siunčiamos i sumatorių. Sumatoriuje sandaugas sudejjus, išèjime yra gaunama srovè $i_{d s 1}$. 


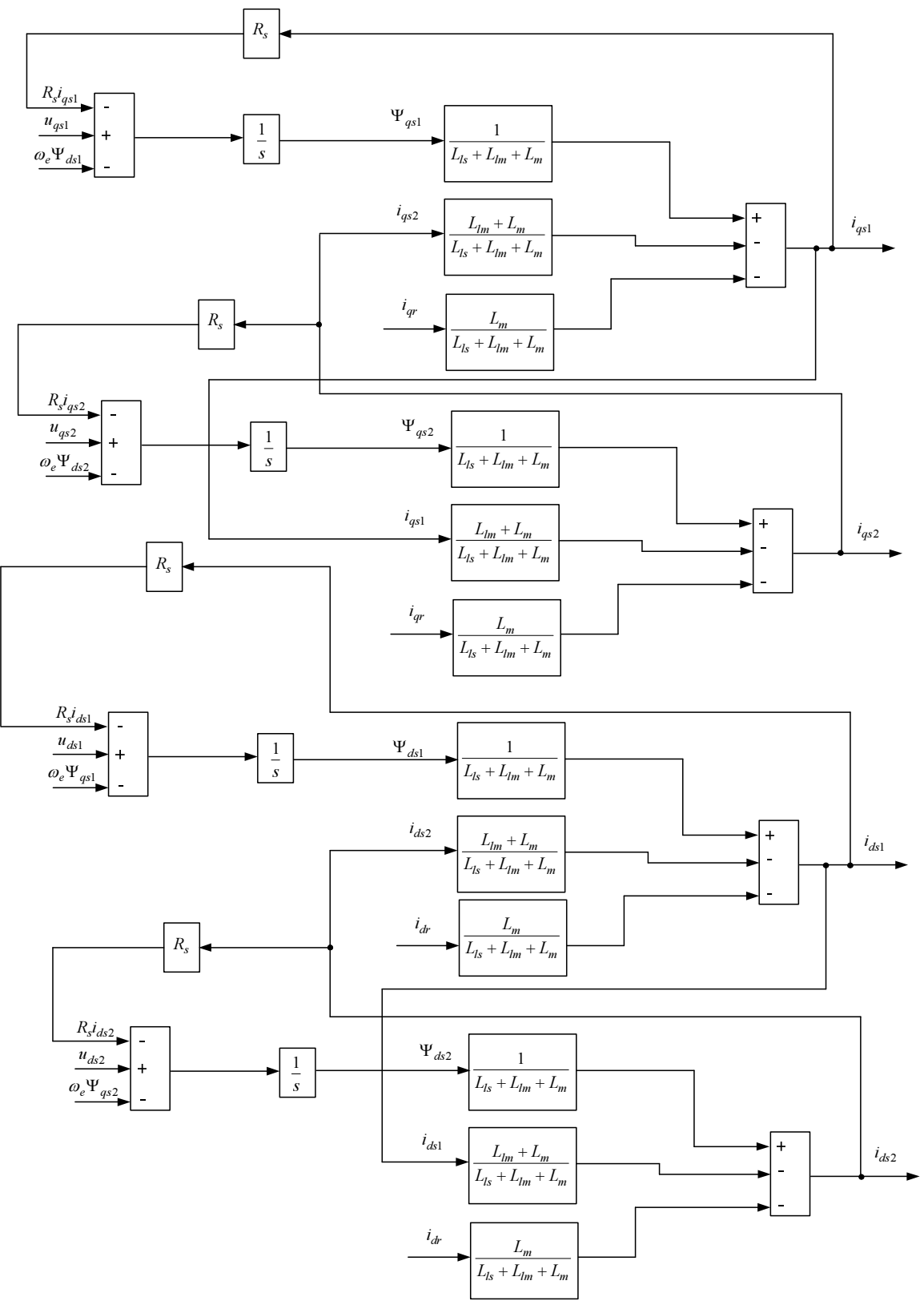

2.22 pav. Šešiafazio asinchroninio variklio statoriaus kompiuterinis modelis Fig. 2.22. Computational stator model of six phase induction motor 
Analogiškai gaunamas srovės projekcijos $d$ ašyje $i_{d s 2}$ skaičiavimo modelis.

Apjungus srautų $\Psi_{q s 1}$ ir $\Psi_{q s 2}$ projekcijų $q$ ašyje modelius, srautų $\Psi_{d s 1}$ ir $\Psi_{d s 2}$ projekcijos $d$ ašyje modelius, bei srovių $i_{q s 1}$ ir $i_{q s 2}$ projekcijų $q$ ašyje modelius, srovių $i_{d s 1}$ ir $i_{d s 2}$ projekcijos $d$ ašyje modelius, gaunamas pereinamųų procesų statoriaus grandineje modelis.

Toliau pagal šešiafazio asinchroninio variklio statoriaus ir rotoriaus srautų išraiškas sudaromas rotoriaus grandinès modelis.

Pirmiausia pagal (1.6) lygčių sistemos pirmają lygti gaunamas rotoriaus srauto projekcijos $q$ ašyje $\Psi_{q r}$ skaičiavimo modelis, kuris pateiktas 2.23 paveiksle.

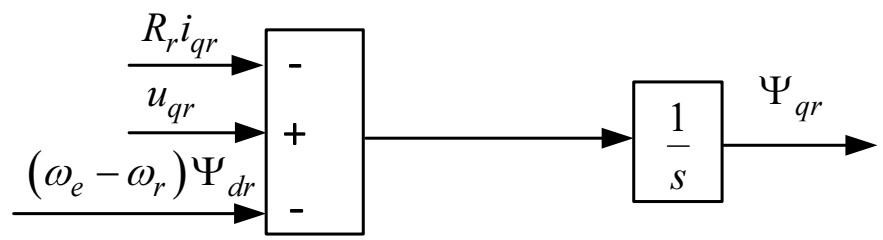

2.23 pav. Rotoriaus srauto projekcijos $q$ ašyje $\Psi_{q r}$ skaičiavimo modelis

Fig. 2.23. Computational model of rotor flux $\Psi_{q r}$ aligned to $q$ axis

Rotoriaus srauto projekcijos $q$ ašyje $\Psi_{q r}$ skaičiavimo modeli sudaro du blokai: triju signalų sumatorius ir integratorius. Sumatoriuje sumuojami trys signalai: $-R_{r} i_{q r}, u_{q r}$ ir $-\left(\omega_{e}-\omega_{r}\right) \Psi_{d r}$. Ju suma integruojama ir gaunama srauto projekcijos $q$ ašyje $\Psi_{q r}$ vertè.

Rotoriaus srauto projekcijos $d$ ašyje $\Psi_{d r}$ skaičiavimo modelị sudaro taip pat du blokai: trijų signalų sumatorius ir integratorius. Sumatoriuje sumuojami trys signalai: $-R_{r} i_{d r}, u_{d r}$ ir $\left(\omega_{e}-\omega_{r}\right) \Psi_{q r}$. Jų suma integruojama ir gaunama srauto projekcija $d$ ašyje $\Psi_{d r}$ vertè.

Toliau sudaromas rotoriaus srovès projekcijos $q$ ašyje $i_{q r}$ skaičiavimo modelis, kuris pateiktas 2.24 paveiksle. Srautas $\Psi_{q r}$ yra dauginamas iš $\frac{1}{L_{l r}+L_{m}}$ ir siunčiamas ị trijų dèmenų sumatorių. Srove $i_{q s 1}$ yra dauginama iš $\frac{L_{m}}{L_{l r}+L_{m}}$, o srovè $i_{q s 2}$ iš $\frac{L_{m}}{L_{l r}+L_{m}}$ ir šios sandaugos su neigiamais ženklais yra 
siunčiami i sumatorių. Sumatoriuje sandaugas sudejus, išèjime yra gaunama rotoriaus srovès $i_{q r}$ vertè.

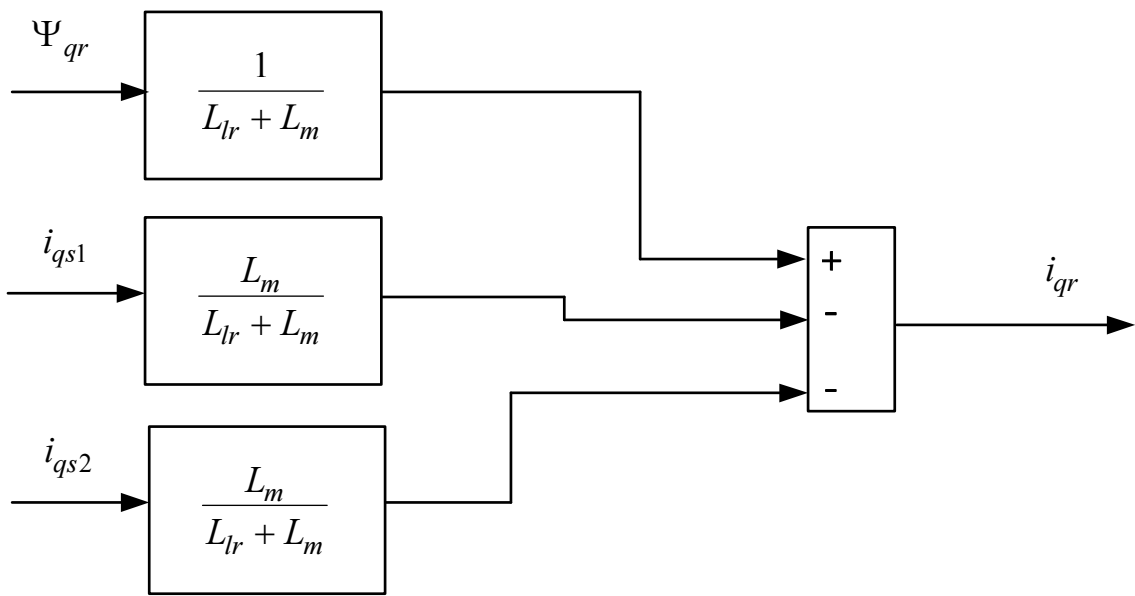

2.24 pav. Rotoriaus srovejs projekcijos $q$ ašyje $i_{q r}$ skaičiavimo modelis

Fig. 2.24. Computational model of rotor current $i_{q r}$ aligned to $q$ axis

Analogiškai gaunamas rotoriaus srovės projekcijos $d$ ašyje $i_{d r}$ skaičiavimo modelis.

Apjungus gautus srautų $\Psi_{q r}$ ir $\Psi_{d r}$ projekcijų atitinkamai $q$ ir $d$ ašyje modelius, bei srovių $i_{d r}$ ir $i_{d r}$ projekcijų atitinkamai $q$ ir $d$ ašyje modelius gaunamas rotoriaus grandinès modelis. Jis pateiktas 2.25 paveiksle.

Šešiafazio asinchroninio variklio imitacinio modelio, sudaryto pagal variklio statoriaus ir rotoriaus srautų išraiškas, momento skaičiavimo modelis yra identiškas momento skaičiavimo modeliui, kuris gautas sudarant imitacinị modeli pagal statoriaus ir rotoriaus srovių išraiškas.

\subsection{Imitacinių modelių naudojimas greitojo prototipo sistemose}

Praeito šimtmečio viduryje išradus skaičiavimo mašinas pradèti taikyti didelių skaičiavimo resursų reikalavę, prieš kelis dešimtmečius sukurti, matematiniai sistemu modeliai. Skaičiavimo technikos tobulejjimas paskatino ne tik taikyti sukurtus skaičiavimo metodus, bet ir pradèti ieškoti naujų sprendimų. Tobulejjo matematinių modelių kūrimo technika, kartu vystèsi techninė įranga. Palaipsniui 
atsirado programos, gebančios ne tik atlikti skaičiavimo veiksmus, bet ir imituoti realias sistemas.

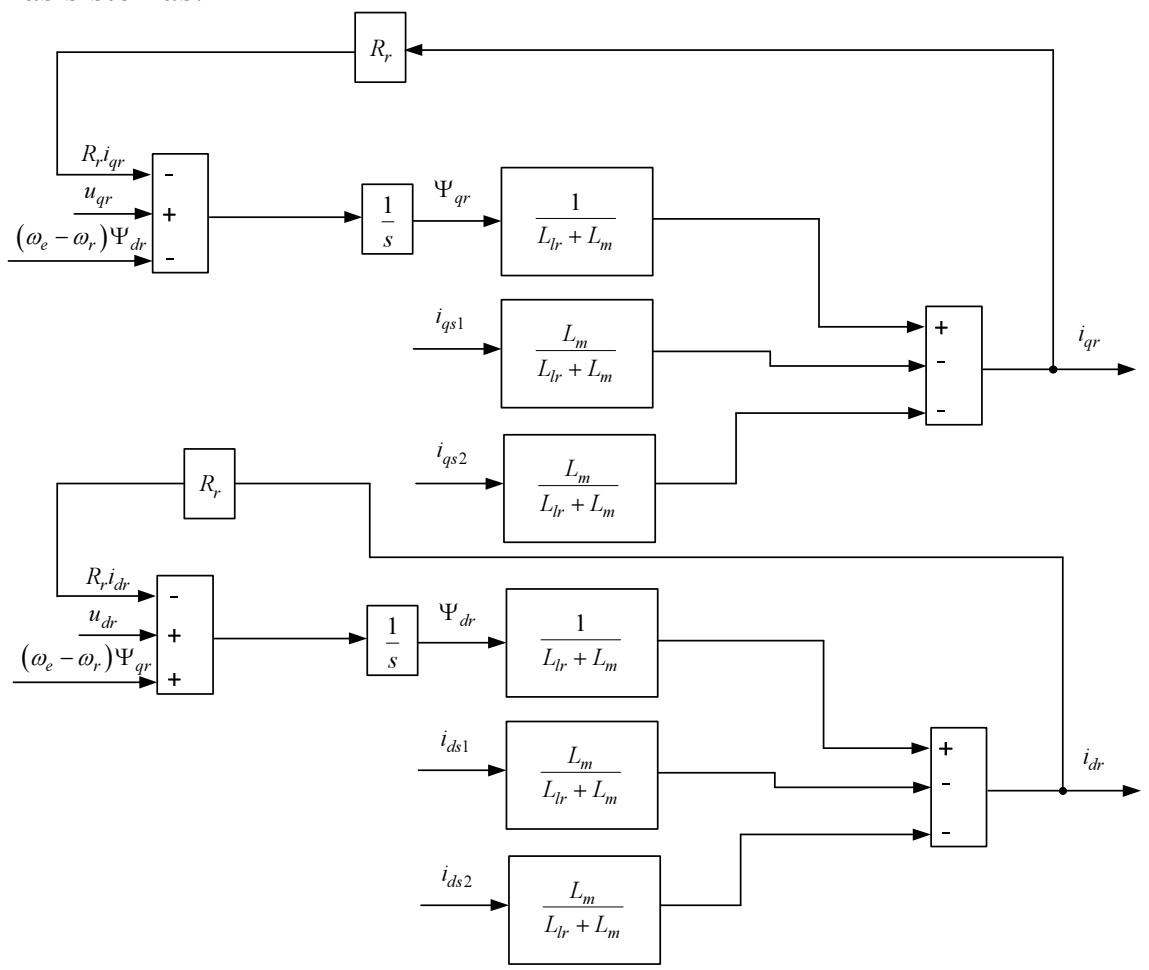

2.25 pav. Šešiafazio asinchroninio variklio rotoriaus grandinès modelis

Fig. 2.25. Computational rotor model of six phase induction motor

Imitacinių programų taikymas sudare galimybę tirti įvairius sistemų režimus ir darbo sąlygas. Jų atsiperkanti nauda paskatino mokslininkus betarpiškai dalyvauti šių programų kūrime ir tobulinime. Imitacinių modelių adekvatumas realioms sistemos leido imitacinius modelius derinti ir naudoti su realiomis sistemomis. Pradèti kurti greitieji sistemų prototipai.

Greitujų prototipų kūrimas tapo efektyviu būdu išbandyti naujai suprojektuotus irenginius su realias sistemas atitinkančiais imitaciniais modeliais. Jų tikslas buvo nustatyti testuojamo objekto patikimumą ir trūkumus prieš pradedant jų serijinę gamybą.

Moksliniuose tyrimuose retai atsižvelgiama i sistemos gamybą, todèl greitojo prototipo kūrimas ir šiai dienai atlieka svarbų mokslinių idèjų sintezès su praktiniu jų taikymu funkciją. Pramonejje greitojo prototipo naudojimas 
leidžia operatyviai atlikti atskirų sistemos mazgų eksperimentinius tyrimus, o po to didinti visos sistemos tikslumą ir optimizuoti ją.

Skiriamos trys greitojo prototipo konfigūracijos: funkcinis greitasis prototipas, perdavimo greitasis prototipas, vidinis greitasis prototipas:

funkcinio greitojo prototipo kūrimo tikslas yra išbandyti naujas idejjas. Šis prototipas apima visą sistemą ir jo paskirtis yra patikrinti, pagrịsti arba ịrodyti idejos koncepciją;

perdavimo greitojo prototipo tikslas pakeisti dali sistemos nauju techniniu sprendimu;

vidinis greitasis prototipas naudojama esamą sistemos ịrangą, o išbandoma yra sistemos ar jos dalies programinè ịranga. Šiai funkcijai atlikti naudojama kompiuterinè įranga.

Visais nurodytais atvejais sistema yra kombinuota: dalis naudojama realios sistemos, o dalis - imitacinès.

\subsection{Antrojo skyriaus išvados}

1. Sudaryti Matlab $^{\mathbb{R}}$ Simulink $^{\mathbb{R}}$ šešiafazio asinchroninio variklio modeliai pagal statoriaus, rotoriaus srovių išraiškas, ir statoriaus, rotoriaus srautų išraiškas, kai statoriuje yra identiškos apvijos. Ivertinus šių apvijų tarpusavio sklaidos efektyvumą galima tirti šešiafazio asinchroninio variklio greičio, momento ir srovių dinaminius vyksmus.

2. Sudarytais Matlab $^{\circledR}$ Simulink $^{\circledR}$ šešiafazio asinchroninio variklio kompiuteriniais modeliais gautos $d-q$ koordinačių sistemos srovių, srautų pereinamujjų vyksmų charakteristikos, iš kurių gali būti apskaičiuotos realaus šešiafazio asinchroninio variklio fazinès srovès ir srautai.

3. Matlab $^{\mathbb{R}}$ Simulink $^{\mathbb{R}}$ imitaciniais modeliais galima tirti sistemas su šešiafaziais asinchroniniais varikliais ir optimizuoti valdymo algoritmus, nenaudojant brangiai kainuojančios techninès įrangos.

4. Matlab ${ }^{\circledR}$ Simulink ${ }^{\circledR}$ imitacinis šešiafazio asinchroninio variklio modelis yra tinkamas naudoti greitojo prototipo sistemose, siekiant atlikti atskirų sistemos mazgų eksperimentinius tyrimus. 


\section{Šešiafazio asinchroninio variklio imitaciniai ir eksperimentiniai tyrimai}

Skyriuje nagrinejama šešiafazio asinchroninio variklio magnetovara. Sudarytos sutelktujų dvisluoksnių sutrumpinto žingsnio ir poliaus žingsnio šešiafazių apvijų sekcijų jungimo schemos, elektrinès schemos išklotinès ir palygintas šių apvijų tarpusavio efektyvumas.

Taip pat pristatyti šešiafazio asinchroninio variklio kompiuterinio modelio, sukurto pagal variklio statoriaus, rotoriaus srovių išraiškas, imitacinio tyrimo rezultatai ir atlikta jų analizè. Šiame skyriuje pateikti šešiafazio asinchroninio variklio pereinamujų vyksmų tyrimai.

Aprašytas bandymų stendas ir pateikta jo struktūrinè schema. Pristatyti eksperimentinio šešiafazès asinchroninès pavaros tyrimo rezultatai. Bandymai atlikti maitinant variklio statoriaus apvijas skirtingų verčių įtampomis. Eksperimentiniai tyrimai vykdyti Vilniaus Gedimino technikos universiteto Elektronikos fakulteto Automatikos katedros laboratorijoje.

Skyriaus pabaigoje apibendrinti imitacinių ir eksperimentinių bandymų rezultatai.

Skyriaus tematika paskelbti 4 autoriaus straipsniai (Kundrotas, et al., 2014; Kundrotas, 2013; Kundrotas, et al., 2013; Rinkevičiene,, Kundrotas, Tolvaišienė, 2013). 


\section{1. Šešiafazès apvijos magnetovara}

Šešiafazę apviją sudaro šešios vienodos fazinès apvijos, suklotos statoriaus grioveliuose kas 60 elektrinių laipsnių. Visose fazinèse apvijose yra vienodas sekcijų (ričių) skaičius, o sekcijose vienodas vijų skaičius. Čia tiriama simetrinè šešiafazè apvija.

Nagrinejjamo statoriaus apvijos maitinamos iš dažnio keitiklio, kurio išẻjimo ìtampų ir srovių fazès skiriasi 60 elektrinių laipsnių kampais. Tai simetrinè šešiafazè srovių sistema, kuri pateikta 3.1 paveiksle. Ją sudaro dvi trifazès sistemos, besiskiriančios 60 elektrinių laipsnių kampu. Srovių fazių seka, pateikta 3.2 paveiksle, yra pirma-trečia-penkta fazès ir antra-ketvirta-šešta fazès.

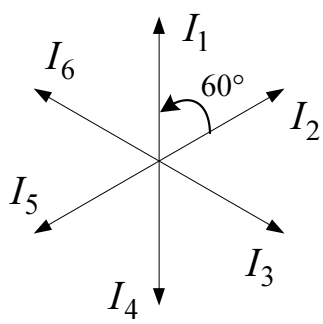

3.1 pav. Simetrinè šešiafazè srovių sistema

Fig. 3.1. Symmetric six phase current system

Statoriaus apvijų fazinès srovès išreiškiamos taip:

$$
\begin{aligned}
& i_{1}=I_{\mathrm{m}} \sin \omega t, \\
& i_{2}=I_{\mathrm{m}} \sin \left(\omega t-\frac{\pi}{3}\right), \\
& i_{3}=I_{\mathrm{m}} \sin \left(\omega t-\frac{2 \pi}{3}\right), \\
& i_{4}=I_{\mathrm{m}} \sin (\omega t-\pi), \\
& i_{5}=I_{\mathrm{m}} \sin \left(\omega t-\frac{4 \pi}{3}\right), \\
& i_{6}=I_{\mathrm{m}} \sin \left(\omega t-\frac{5 \pi}{3}\right),
\end{aligned}
$$

čia $I_{m}$ - fazinè srovè.

Šios srovès kuria vienodos amplitudès $F_{\mathrm{m}}$ pulsuojamąsias magnetovaras, kurių pirmoji harmonika reiškiama taip: 


$$
\begin{aligned}
& F_{1}=F_{\mathrm{m}} \sin \omega t \cdot \cos \frac{\pi}{\tau} x, \\
& F_{2}=F_{\mathrm{m}} \sin \left(\omega t-\frac{\pi}{3}\right) \cdot \cos \left(\frac{\pi}{\tau} x-\frac{\pi}{3}\right), \\
& F_{3}=F_{\mathrm{m}} \sin \left(\omega t-\frac{2 \pi}{3}\right) \cdot \cos \left(\frac{\pi}{\tau} x-\frac{2 \pi}{3}\right), \\
& F_{4}=F_{\mathrm{m}} \sin (\omega t-\pi) \cdot \cos \left(\frac{\pi}{\tau} x-\pi\right), \\
& F_{5}=F_{\mathrm{m}} \sin \left(\omega t-\frac{4 \pi}{3}\right) \cdot \cos \left(\frac{\pi}{\tau} x-\frac{4 \pi}{3}\right), \\
& F_{6}=F_{\mathrm{m}} \sin \left(\omega t-\frac{5 \pi}{3}\right) \cdot \cos \left(\frac{\pi}{\tau} x-\frac{5 \pi}{3}\right),
\end{aligned}
$$

čia $\tau$-poliaus žingsnis; $x$ - erdvinè koordinatè.

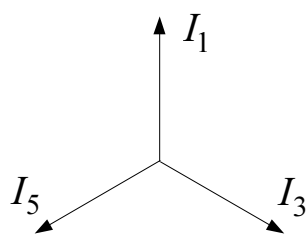

a)

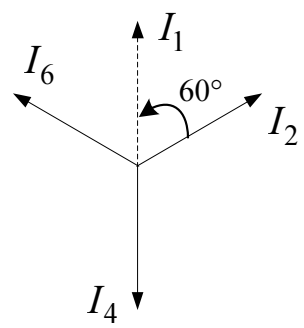

b)

3.2 pav. Srovių vektorių diagramos

Fig. 3.2. Diagram of currents vectors

Tokią šešiafazę magnetovarų sistemą sudaro dvi simetriškos trifazès sistemos. Pirmoji sistema išreiškiama:

$$
\begin{aligned}
& F_{1}=F_{\mathrm{m}} \sin \omega t \cdot \cos \frac{\pi}{\tau} x, \\
& F_{3}=F_{\mathrm{m}} \sin \left(\omega t-\frac{2 \pi}{3}\right) \cdot \cos \left(\frac{\pi}{\tau} x-\frac{2 \pi}{3}\right), \\
& F_{5}=F_{\mathrm{m}} \sin \left(\omega t-\frac{4 \pi}{3}\right) \cdot \cos \left(\frac{\pi}{\tau} x-\frac{4 \pi}{3}\right),
\end{aligned}
$$

antroji išreiškiama: 


$$
\begin{aligned}
& F_{2}=F_{\mathrm{m}} \sin \left(\omega t-\frac{\pi}{3}\right) \cdot \cos \left(\frac{\pi}{\tau} x-\frac{\pi}{3}\right), \\
& F_{4}=F_{\mathrm{m}} \sin (\omega t-\pi) \cdot \cos \left(\frac{\pi}{\tau} x-\pi\right), \\
& F_{6}=F_{\mathrm{m}} \sin \left(\omega t-\frac{5 \pi}{3}\right) \cdot \cos \left(\frac{\pi}{\tau} x-\frac{5 \pi}{3}\right) .
\end{aligned}
$$

Kiekviena fazinè magnetovara yra pulsuojamoji ir skaidoma i dvi dedamąsias:

$$
\begin{gathered}
F_{1}=F_{\mathrm{m}} \sin \omega t \cdot \cos \frac{\pi}{\tau} x=\frac{1}{2} F_{\mathrm{m}} \sin \left(\omega t-\frac{\pi}{\tau} x\right)+ \\
+\frac{1}{2} F_{\mathrm{m}} \sin \left(\omega t+\frac{\pi}{\tau} x\right) .
\end{gathered}
$$

Išskaidžius fazines magnetovaras gauname:

$$
\begin{aligned}
F_{1} & =\frac{1}{2} F_{\mathrm{m}} \sin \left(\omega t-\frac{\pi}{\tau} x\right)+\frac{1}{2} F_{\mathrm{m}} \sin \left(\omega t+\frac{\pi}{\tau} x\right), \\
F_{2} & =\frac{1}{2} F_{\mathrm{m}} \sin \left(\omega t-\frac{\pi}{\tau} x\right)+\frac{1}{2} F_{\mathrm{m}} \sin \left(\omega t+\frac{\pi}{\tau} x+\frac{2 \pi}{3}\right), \\
F_{3} & =\frac{1}{2} F_{\mathrm{m}} \sin \left(\omega t-\frac{\pi}{\tau} x\right)+\frac{1}{2} F_{\mathrm{m}} \sin \left(\omega t+\frac{\pi}{\tau} x+\frac{4 \pi}{3}\right), \\
F_{4} & =\frac{1}{2} F_{\mathrm{m}} \sin \left(\omega t-\frac{\pi}{\tau} x\right)+\frac{1}{2} F_{\mathrm{m}} \sin \left(\omega t+\frac{\pi}{\tau} x+2 \pi\right)= \\
& =\frac{1}{2} F_{\mathrm{m}} \sin \left(\omega t-\frac{\pi}{\tau} x\right)+\frac{1}{2} F_{\mathrm{m}} \sin \left(\omega t+\frac{\pi}{\tau} x\right), \\
F_{5} & =\frac{1}{2} F_{\mathrm{m}} \sin \left(\omega t-\frac{\pi}{\tau} x\right)+\frac{1}{2} F_{\mathrm{m}} \sin \left(\omega t+\frac{\pi}{\tau} x+\frac{8 \pi}{3}\right)= \\
& =\frac{1}{2} F_{\mathrm{m}} \sin \left(\omega t-\frac{\pi}{\tau} x\right)+\frac{1}{2} F_{\mathrm{m}} \sin \left(\omega t+\frac{\pi}{\tau} x+\frac{2 \pi}{3}\right), \\
F_{6} & =\frac{1}{2} F_{\mathrm{m}} \sin \left(\omega t-\frac{\pi}{\tau} x\right)+\frac{1}{2} F_{\mathrm{m}} \sin \left(\omega t+\frac{\pi}{\tau} x+\frac{10 \pi}{3}\right)= \\
& =\frac{1}{2} F_{\mathrm{m}} \sin \left(\omega t-\frac{\pi}{\tau} x\right)+\frac{1}{2} F_{\mathrm{m}} \sin \left(\omega t+\frac{\pi}{\tau} x+\frac{4 \pi}{3}\right) .
\end{aligned}
$$

Suminė magnetovara randama sumuojant visų variklio fazių magnetovaras: 


$$
\sum F=F_{1}+F_{2}+F_{3}+F_{4}+F_{5}+F_{6} .
$$

Tiesioginès ir atvirkštinès dedamosios sumuojamos atskirai. Tiesioginè suminès magnetovaros dedamoji:

$$
\sum F=3 F_{m} \sin \left(\omega t-\frac{\pi}{\tau} x\right) .
$$

Atvirkštinę suminę magnetovaros dedamąą sudaro dvi simetriškos trifazès dedamosios:

$$
\begin{aligned}
& F_{1}=\frac{1}{2} F_{\mathrm{m}} \sin \left(\omega t+\frac{\pi}{\tau} x\right), \\
& F_{3}=\frac{1}{2} F_{\mathrm{m}} \sin \left(\omega t+\frac{\pi}{\tau} x+\frac{4 \pi}{3}\right), \\
& F_{5}=\frac{1}{2} F_{\mathrm{m}} \sin \left(\omega t+\frac{\pi}{\tau} x+\frac{2 \pi}{3}\right),
\end{aligned}
$$

ir

$$
\begin{aligned}
& F_{2}=\frac{1}{2} F_{\mathrm{m}} \sin \left(\omega t+\frac{\pi}{\tau} x+\frac{2 \pi}{3}\right), \\
& F_{4}=\frac{1}{2} F_{\mathrm{m}} \sin \left(\omega t+\frac{\pi}{\tau} x\right), \\
& F_{6}=\frac{1}{2} F_{\mathrm{m}} \sin \left(\omega t+\frac{\pi}{\tau} x+\frac{4 \pi}{3}\right) .
\end{aligned}
$$

3.3 paveiksle parodytos abi trifazès magnetovaros atvirkštinès sekos dedamosios.
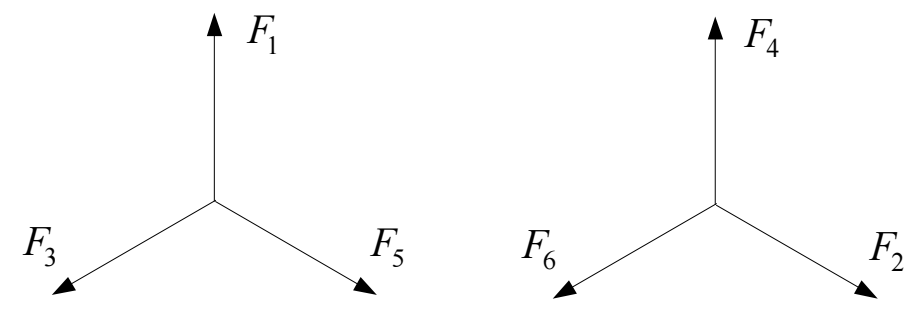

3.3 pav. Trifazès magnetovaros atvirkštinès sekos dedamosios Fig. 3.3. Reverse sequence components of three phase magnetomotive 
Tiesioginès sekos dedamujų eilè yra $F_{1}-F_{3}-F_{5}$ ir $F_{2}-\mathrm{F}_{4}-F_{6}$, o atvirkštinių $F_{1}$ $F_{5}-F_{3}$ ir $F_{2}-F_{6}-F_{4}$. Simetriškos trifazès sistemos magnetovaros atvirkštinių dedamuju suma kiekvienu laiko momentu lygi nuliui, todèl šešiafazès mašinos suminè magnetovara turi tik vieną tiesioginę dedamają, kuri ir yra sukamoji magnetovara:

$$
\Sigma F=3 F_{\mathrm{m}} \sin \left(\omega t-\frac{\pi}{\tau} x\right)
$$

Ši išraiška taikoma tada, kai tenkinamos šios trys sąlygos:

1) statoriaus apvijos maitinamos simetriška šešiafaze itampa, kurios itampų ir srovių fazès skiriasi 60 elektrinių laipsnių kampais;

2) statoriaus grioveliuose kas 60 elektrinių laipsnių suklotos šešios fazinès apvijos;

3) visų fazių magnetovaros lygios.

Jeigu bent viena sąlyga netenkinama, atsiranda atvirkštinè dedamoji ir suminè magnetovara tampa elipsine.

Trifazès mašinos magnetovara yra:

$$
\Sigma F=\frac{3}{2} F_{\mathrm{m}} \sin \left(\omega t-\frac{\pi}{\tau} x\right) .
$$

Palyginus gautas išraiškas (3.11) ir (3.12) galima teigti, kad šešiafazès mašinos magnetovara yra ekvivalentiška dviejų trifazių mašinų magnetovarai.

\subsection{Sutelktosios dvisluoksnès statoriaus šešiafazès apvijos}

Dvisluoksnès statoriaus apvijos turi daug privalumų lyginant su vienasluoksnèmis statoriaus apvijomis: paprastesnè ir pigesnè gamyba, apvijos gali būti trupmeninès, sutrumpinto arba poliaus žingsnio.

\section{Sutelktoji dvisluoksnè sutrumpinto žingsnio šešiafazè apvija}

Statoriaus, kuriam sudaroma sutelktoji dvisluoksnė sutrumpinto žingsnio apvija, buvo užduoti tokie parametrai: griovelių skaičius statoriuje $Z_{1}=48$, polių skaičius $P=8$, fazių skaičius $m=6$, poliaus žingsnis $\tau=6$, griovelio žingsnis elektriniais laipsniais $\alpha=\frac{180^{\circ}}{6}=30^{\circ}$, fazės griovelių skaičius po poliumi $q=1$, 
apvijos žingsnis $\mathrm{y}=5$, fazine zona elektriniais laipsniais $\sigma_{1}=\frac{180^{\circ}}{5}=36^{\circ}$, kampas tarp fazinių srovių fazorių elektriniais laipsniais $60^{\circ}$.

Sudaryta sutelktosios dvisluoksnès sutrumpinto žingsnio šešiafazès apvijos sekciju jungimo schema pateikta 3.13 paveiksle.

Pirmoji fazinès apvijos sekcija suklota 1 ir 6 griovelius taip, kad vienas sekcijos šonas yra 1 griovelio viršutiniame sluoksnyje, o kitas šonas - 6 griovelio apatiniame sluoksnyje $6^{6}$. Pirmosios fazinès apvijos pradžia yra 1 griovelyje, o 6 griovelio apatiniame sluoksnyje $6^{6}$ yra pirmosios sekcijos galas. Iš viso fazinèje apvijoje yra 8 nuosekliai sujungtos sekcijos, kurių šonai yra po kiekvienu poliumi. Toliau pirmosios sekcijos galas $6^{6}$ sujungtas su kitos sekcijos, kuri suklota 6 ir 11 grioveliuose, galu 11', o pradžia yra 6 griovelio viršutiniame sluoksnyje. Iš 6 griovelio viršutinio sluoksnio pereinama i kitą polių porą, kuri nuo apvijos pradžios yra nutolusi 360 elektrinių laipsnių. Statoriaus griovelio žingsnis yra 30 elektrinių laipsnių, todèl 360 elektrinių laipsnių yra 12 griovelių. Dèl to iš 6 griovelio viršutinio sluoksnio pereinama $i$ 13 griovelio viršutini sluoksnị. Toliau viskas kartojasi, kol pasiekiamas 42 griovelio viršutinis sluoksnis, kur yra pirmosios fazinès apvijos pabaiga.

Antrosios fazinès apvijos sekcija suklota ị 3 griovelio viršutini sluoksni, nes ji turi būti nutolusi nuo pirmosios fazinès apvijos pradžios 60 elektrinių laipsnių, o tai sudaro du griovelius. Toliau sujungta analogiškai pirmosios fazinès apvijos atveju. 44 griovelio viršutinis sluoksnis yra antrosios fazinès apvijos galas. Trečiosios, ketvirtosios, penktosios ir šeštosios fazinių apvijų pradžios yra suklotos atitinkamai i 5, 7,9 ir 11 griovelių viršutinius sluoksnius, o šių fazinių apvijų galai yra sukloti atitinkamai i $46,48,2$ ir 4 grioveliu viršutinius sluoksnius. Šių fazinių apvijų sekcijos yra sujungtos analogiškai pirmosios ir antrosios fazinių apvijų atvejams.

Akimirkinès srovių kryptys sutelktojoje dvisluoksneje sutrumpinto žingsnio šešiafazèje apvijoje laiko momentu $t=0$ pateiktos 3.14 pav. a. Matyti, kad srovių fazès skiriasi 60 elektrinių laipsnių kampais. Laiko momentu $\mathrm{t}=0$ pirmosios, antrosios ir šeštosios fazių srovių kryptys bus priešingos krypties nei trečiosios, ketvirtosios ir penktosios fazių srovių kryptys.

Pagal sutelktosios dvisluoksnès sutrumpinto žingsnio šešiafazès apvijos sekciju jungimo schemą, kuri pateikta 3.13 paveiksle, sudaromas pirmosios, antrosios, trečiosios, ketvirtosios, penktosios ir šeštosios fazinių apviju laidininkų pasiskirstymas 48 statoriaus grioveliuose. Atsižvelgiant $i$ akimirkines sroviu kryptis laiko momentu $t=0$, kurios pateiktos 3.14 paveikslo a, sudaromas fazinių srovių krypčių pasiskirstymas statoriaus griovelių 
viršutiniuose ir apatiniuose sluoksniuose. 3.14 paveikslo $b$, viršutinejje eilutèje nurodyti statoriaus griovelio numeriai, vidurineje eiluteje pateiktos srovių kryptys griovelių viršutiniuose sluoksniuose, o apatinèje eilutejje pateiktos srovių kryptys apatiniuose grioveliu sluoksniuose. Tais atvejais, kai griovelio viršutiniame ir apatiniame sluoksniuose ženklai sutampa, sakoma, kad srovių kryptys sutampa, o tais atvejais, kuomet ženklai nesutampa - srovių kryptys viršutiniame ir apatiniame griovelio sluoksniuose yra priešingų krypčių.

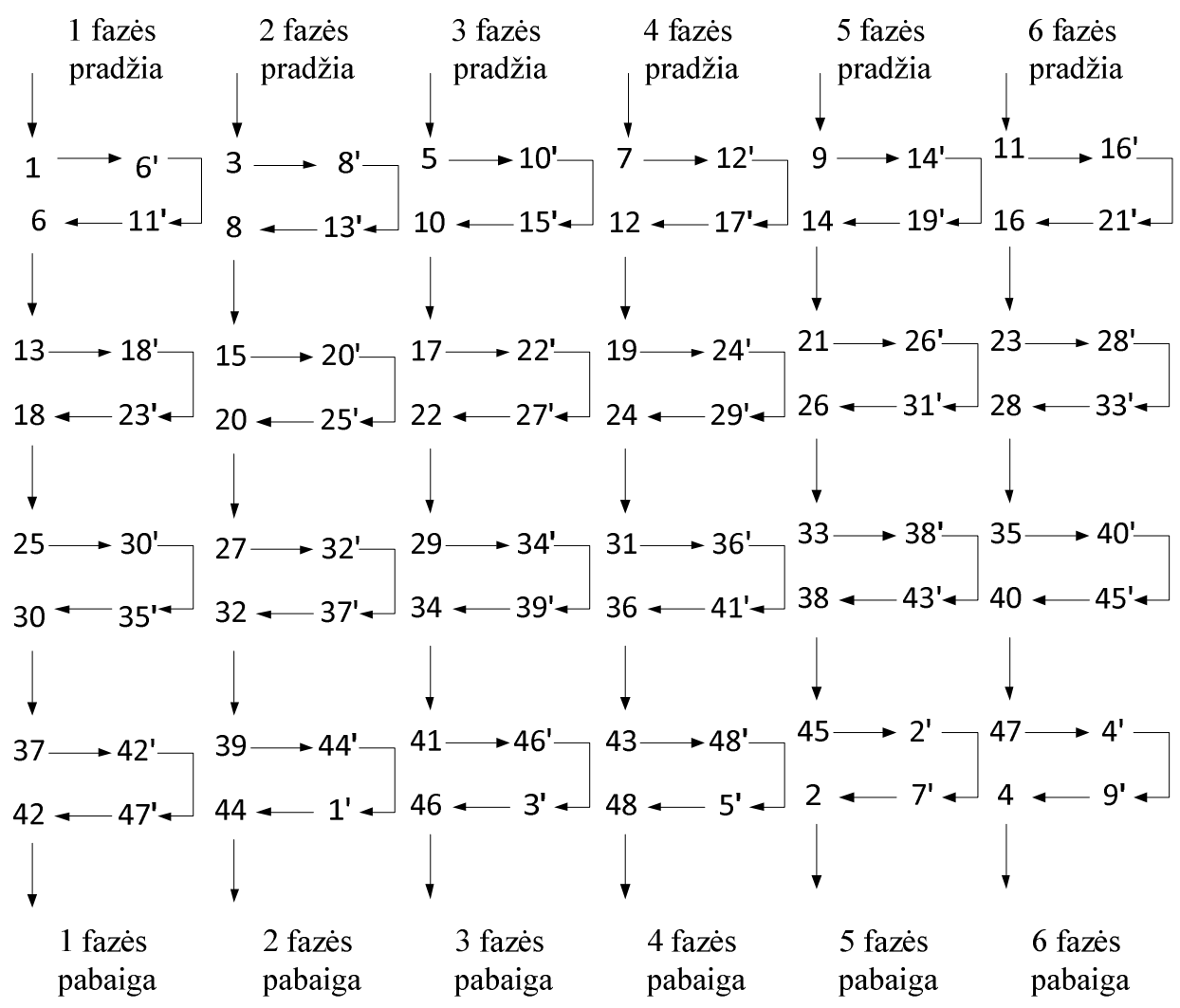

3.13 pav. Sutelktosios dvisluoksnės sutrumpinto žingsnio šešiafazės apvijos sekcijų jungimo schema

Fig. 3.13. Connection of concentrated double layer short pitch coil six phase winding section

Sutelktosios dvisluoksnès sutrumpinto žingsnio šešiafazès apvijos elektrinès schemos išklotinè ir šios apvijos sukamosios magnetovaros 
pasiskirstymas erdvejje pateiktas 3.3 paveiksle. Apvija suklota 48 grioveliuose. $\mathrm{U} 1, \mathrm{~V} 1, \mathrm{~W} 1, \mathrm{U}^{\star} 1, \mathrm{~V}^{\star} 1, \mathrm{~W}^{\star} 1$ simboliais pažymèta atitinkamai pirmosios, antrosios, trečiosios, ketvirtosios, penktosios ir šeštosios fazinių apvijų pradžios, o U2, V2, W2, U`2, V‘2, W`2 atitinkamai fazinių apvijų pabaigos. 3.15 paveikslèlio grafineje dalyje $F$ simboliu pažymèta sukamoji magnetovara yra atidèta santykiniais dydžiais, $x$ simboliu pažymèta erdvinè koordinatè, $\tau$ simboliu pažymètas poliaus žingsnis.

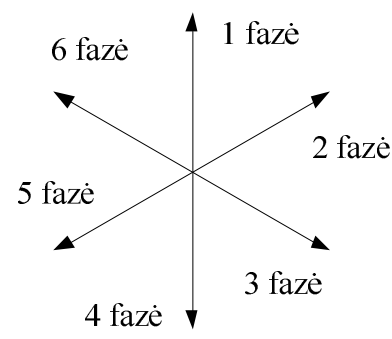

a)

\begin{tabular}{|c|c|c|c|c|c|c|c|c|c|c|c|c|c|c|}
\hline 1 & 2 & 3 & 4 & 5 & 6 & 7 & 8 & 9 & 10 & 11 & 12 & 13 & 14 & 15 \\
\hline+ & + & + & - & - & - & - & - & - & + & + & + & + & + & + \\
\hline+ & + & - & - & - & - & - & - & + & + & + & + & + & + & - \\
\hline
\end{tabular}

\begin{tabular}{|c|c|c|c|c|c|c|c|c|c|c|c|c|c|c|}
\hline 16 & 17 & 18 & 19 & 20 & 21 & 22 & 23 & 24 & 25 & 26 & 27 & 28 & 29 & 30 \\
\hline- & - & - & - & - & - & + & + & + & + & + & + & - & - & - \\
\hline- & - & - & - & - & + & + & + & + & + & + & - & - & - & - \\
\hline
\end{tabular}

\begin{tabular}{|c|c|c|c|c|c|c|c|c|c|c|c|c|c|c|}
\hline 31 & 32 & 33 & 34 & 35 & 36 & 37 & 38 & 39 & 40 & 41 & 42 & 43 & 44 & 45 \\
\hline- & - & - & + & + & + & + & + & + & - & - & - & - & - & - \\
\hline- & - & + & + & + & + & + & + & - & - & - & - & - & - & + \\
\hline
\end{tabular}

\begin{tabular}{|c|c|c|}
\hline 46 & 47 & 48 \\
\hline+ & + & + \\
\hline+ & + & + \\
\hline
\end{tabular}

b)

3.14 pav. Akimirkinès fazinių srovių kryptys: a) tinklo srovè laiko momentu $t=0$;

b) statoriaus griovelių viršutiniuose ir apatiniuose sluoksniuose

Fig. 3.14. Instantaneous current directions: a) supply current at time instant $t=0$; b) in the the uper and lower layers of slots 


\section{Sutelktoji dvisluoksnè poliaus žingsnio šešiafazè apvija}

Statoriaus, kuriam sudaroma sutelktoji dvisluoksnè poliaus žingsnio apvija parametrai: griovelių skaičius statoriuje $Z_{1}=48$, polių skaičius $P=8$, fazių skaičius $m=6$, poliaus žingsnis $\tau=6$, griovelio žingsnis elektriniais laipsniais $\alpha=\frac{180^{\circ}}{6}=30^{\circ}$, fazès griovelių skaičius po poliumi $q=1$, apvijos žingsnis $\mathrm{y}=6$, fazinè zona elektriniais laipsniais $\sigma_{2}=\frac{180^{\circ}}{6}=30^{\circ}$, kampas tarp fazinių srovių fazorių elektriniais laipsniais $60^{\circ}$.

Sudaryta sutelktosios dvisluoksnès poliaus žingsnio šešiafazès apvijos sekcijų jungimo schema pateikta 3.15 paveiksle.
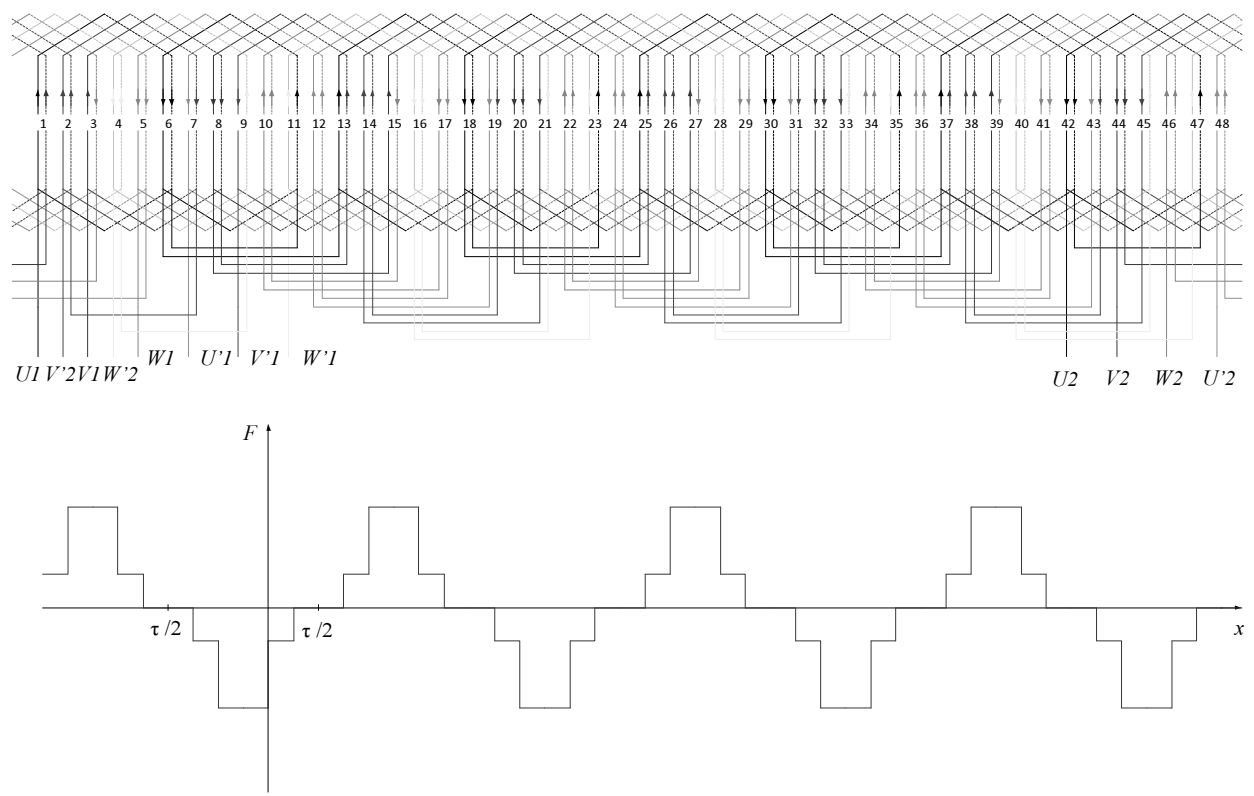

3.15 pav. Sutelktosios dvisluoksnės sutrumpinto žingsnio šešiafazės apvijos elektrinės schemos išklotinè ir jos magnetovaros pasiskirstymas erdvejje

Fig. 3.15. Connection of concentrated double layer short pitch coil six phase winding section and space distribution of magnetomotive force 
Sutelktosios dvisluoksnès poliaus žingsnio šešiafazès apvijos atveju pirmoji fazinès apvijos sekcija suklota $i$ ir 7 griovelius taip, kad vienas sekcijos šonas yra 1 griovelio viršutiniame sluoksnyje, o kitas šonas -7 griovelio apatiniame sluoksnyje $7^{\circ}$. Pirmosios fazinès apvijos pradžia yra 1 griovelyje, o 7 griovelio apatiniame sluoksnyje $7^{6}$ yra pirmosios sekcijos galas. Iš viso fazineje apvijoje, kaip ir sutelktosios dvisluoksnès sutrumpinto žingsnio šešiafazès apvijos atveju, yra 8 nuosekliai sujungtos sekcijos, kurių šonai yra po kiekvienu poliumi. Toliau pirmosios sekcijos galas $7^{\text {‘ }}$ sujungtas su kitos sekcijos, kuri suklota 6 ir 12 grioveliuose, galu 12', o pradžia yra 6 griovelio viršutiniame sluoksnyje. Iš 6 griovelio viršutinio sluoksnio pereinama i kitą polių porą, kuri nuo apvijos pradžios yra nutolusi 360 elektrinių laipsnių t. y. iš 6 griovelio viršutinio sluoksnio pereinama ị 13 griovelio viršutinị sluoksnị. Toliau viskas kartojasi, kol pasiekiamas 42 griovelio viršutinis sluoksnis, kur yra pirmosios fazinès apvijos pabaiga.

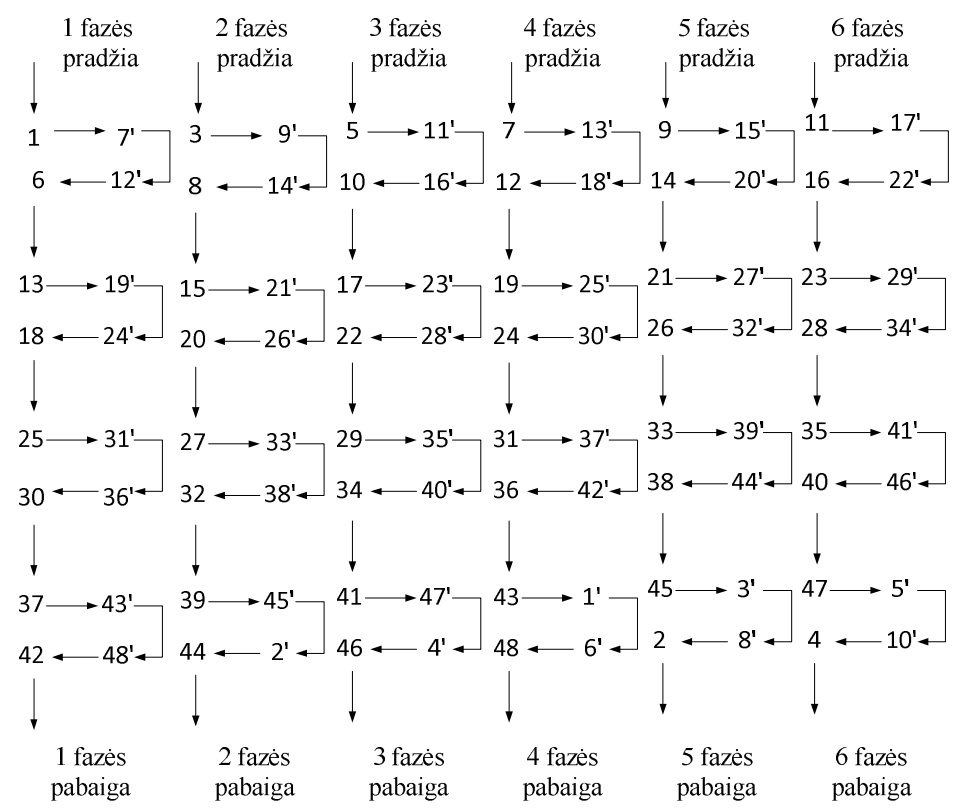

3.15 pav. Sutelktosios dvisluoksnès poliaus žingsnio šešiafazės apvijos sekcijų jungimo schema

Fig. 3.15. Connection of concentrated double layer full pitch coil six phase winding section

Antrosios fazinės apvijos sekcija suklota ị 3 griovelio viršutinị sluoksni, nes ji turi būti nutolusi nuo pirmosios fazinès apvijos pradžios 60 elektrinių laipsnių, 
ir i 9 griovelio apatinị sluoksnị $9^{6}$. Toliau sujungta analogiškai pirmosios fazinès apvijos atveju. 44 griovelio viršutinis sluoksnis yra antrosios fazinès apvijos galas. Trečiosios, ketvirtosios, penktosios ir šeštosios fazinių apvijų pradžios yra suklotos atitinkamai i 5, 7,9 ir 11 griovelių viršutinius sluoksnius, o šių fazinių apvijų galai yra sukloti atitinkamai i $46,48,2$ ir 4 griovelių viršutinius sluoksnius. Šių fazinių apvijų sekcijos yra sujungtos analogiškai pirmosios ir antrosios fazinių apvijų atvejams.

Akimirkinès srovių kryptys sutelktojoje dvisluoksnejje poliaus žingsnio šešiafazeje apvijoje laiko momentu $t=0$ pateikta 3.16 paveikslo a. Srovių fazès skiriasi 60 elektrinių laipsnių kampais. Laiko momentu $t=0$ pirmosios, antrosios ir šeštosios fazių srovių kryptys bus priešingos krypties nei trečiosios, ketvirtosios ir penktosios fazių srovių kryptys.

Pagal sutelktosios dvisluoksnès poliaus žingsnio šešiafazès apvijos sekcijų jungimo schemą, pateiktą 3.15 paveiksle, sudaromas pirmosios, antrosios, trečiosios, ketvirtosios, penktosios ir šeštosios fazinių apvijų laidininkų pasiskirstymas 48 statoriaus grioveliuose. Atsižvelgiant $\mathfrak{i}$ akimirkines srovių kryptis laiko momentu $t=0$ sudaromas fazinių srovių krypčiu pasiskirstymas statoriaus griovelių viršutiniuose ir apatiniuose sluoksniuose. 3.16 paveikslo $b$ viršutineje eiluteje nurodyti statoriaus griovelio numeriai, vidurinèje eiluteje pateiktos srovių kryptys griovelių viršutiniuose sluoksniuose, o apatinejje eilutejje pateiktos sroviu kryptys apatiniuose griovelių sluoksniuose. Tais atvejais, kai griovelio viršutiniame ir apatiniame sluoksniuose ženklai sutampa, sakoma, kad srovių kryptys sutampa, o tais atvejais, kuomet ženklai nesutampa - srovių kryptys viršutiniame ir apatiniame griovelio sluoksniuose yra priešingų krypčių.

Sutelktosios dvisluoksnès sutrumpinto žingsnio šešiafazès apvijos elektrinès schemos išklotine ir šios apvijos sukamosios magnetovaros pasiskirstymas erdvejje pateiktas 3.17 paveiksle. Apvija suklota 48 grioveliuose. $\mathrm{U} 1, \mathrm{~V} 1, \mathrm{~W} 1, \mathrm{U}^{`} 1, \mathrm{~V}^{`} 1, \mathrm{~W}^{`} 1$ simboliais pažymėta atitinkamai pirmosios, antrosios, trečiosios, ketvirtosios, penktosios ir šeštosios fazinių apvijų pradžios, o U2, V2, W2, U`2, V‘2, W`2 atitinkamai fazinių apvijų pabaigos. 3.17 paveikslo grafinèje dalyje $F$ simboliu pažymèta sukamoji magnetovara yra atidèta santykiniais dydžiais, $x$ simboliu pažymèta erdvinè koordinatè, $\tau$ simboliu pažymètas poliaus žingsnis.

\section{Sutelktuju dvisluoksnių šešiafazių apvijų palyginimas}

Sutelktosios dvisluoksnès sutrumpinto žingsnio šešiafazès apvijos atveju, nagrinejjant akimirkines srovių vertes poliaus žingsnio ribose matyti, kad penkių griovelių viršutinio ir apatinio sluoksnio srovių kryptys sutampa, o vieno 
nesutampa. Esant sutelktajai dvisluoksnei poliaus žingsnio šešiafazei apvijai akimirkinès srovių vertès viso poliaus žingsnio griovelių viršutiniame ir apatiniame sluoksniuose sutampa.

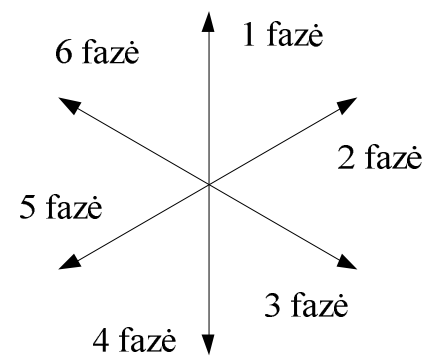

a)

\begin{tabular}{|c|c|c|c|c|c|c|c|c|c|c|c|c|c|c|}
\hline 1 & 2 & 3 & 4 & 5 & 6 & 7 & 8 & 9 & 10 & 11 & 12 & 13 & 14 & 15 \\
\hline+ & + & + & - & - & - & - & - & - & + & + & + & + & + & + \\
\hline+ & + & + & - & - & - & - & - & - & + & + & + & + & + & + \\
\hline
\end{tabular}

\begin{tabular}{|c|c|c|c|c|c|c|c|c|c|c|c|c|c|c|}
\hline 16 & 17 & 18 & 19 & 20 & 21 & 22 & 23 & 24 & 25 & 26 & 27 & 28 & 29 & 30 \\
\hline- & - & - & - & - & - & + & + & + & + & + & + & - & - & - \\
\hline- & - & - & - & - & - & + & + & + & + & + & + & - & - & - \\
\hline
\end{tabular}

\begin{tabular}{|c|c|c|c|c|c|c|c|c|c|c|c|c|c|c|}
\hline 31 & 32 & 33 & 34 & 35 & 36 & 37 & 38 & 39 & 40 & 41 & 42 & 43 & 44 & 45 \\
\hline- & - & - & + & + & + & + & + & + & - & - & - & - & - & - \\
\hline- & - & - & + & + & + & + & + & + & - & - & - & - & - & - \\
\hline
\end{tabular}

\begin{tabular}{|c|c|c|}
\hline 46 & 47 & 48 \\
\hline+ & + & + \\
\hline+ & + & + \\
\hline
\end{tabular}

b)

3.16 pav. Akimirkinès fazinių srovių kryptys: a) tinklo srovè laiko momentu $t=0$;

b) statoriaus griovelių viršutiniuose ir apatiniuose sluoksniuose

Fig. 3.16. Instantaneous current directions: a) supply current at time instant $t=0$; b) in the the uper and lower layers of slots

Sutelktosios dvisluoksnès sutrumpinto žingsnio šešiafazès apvijos atveju magnetovaros jèga $F_{l}(\varphi)$ vieno poliaus žingsnio ribose turi 3.18 pav. pateiktą formą. 


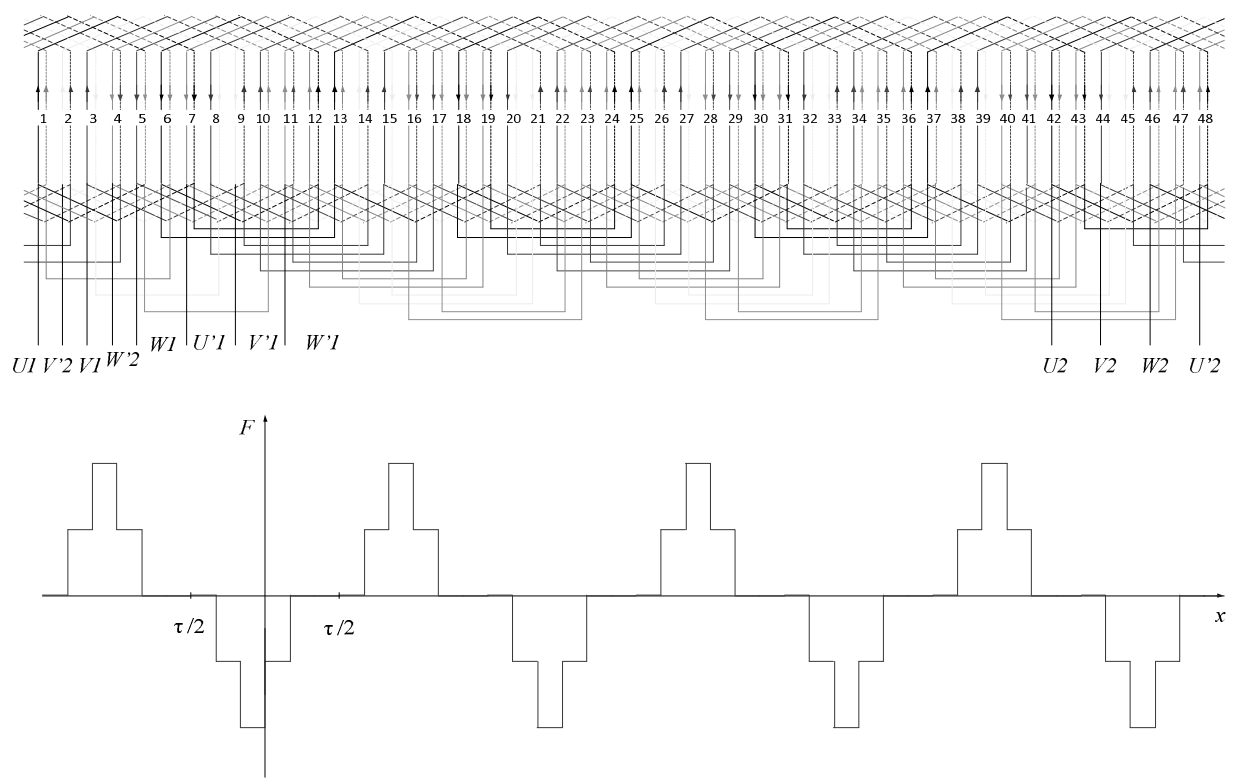

3.17 pav. Sutelktosios dvisluoksnès poliaus žingsnio šešiafazès apvijos elektrinès schemos išklotinè ir jos magnetovaros pasiskirstymas erdvejje

Fig. 3.17. Connection of concentrated double layer full pitch coil six phase winding section and space distribution of magnetomotive force

Apvijos magnetovarą išskleisime erdvinių harmonikų Furjè eilute. 3.18 paveiksle pateiktos $F_{l}(\varphi)$ funkcijos Furje transformacijos koeficientus galima apskaičiuoti taip:

$$
\begin{aligned}
& b_{1, k}=\frac{2 A_{1}}{\pi} \int_{\pi / 6}^{5 \pi / 6} \sin k \phi d \phi+\frac{2 A_{2}}{\pi} \int_{\pi / 3}^{2 \pi / 3} \sin k \phi d \phi= \\
& =\frac{4}{\pi k}\left(A_{1} \sin \frac{\pi k}{3}+A_{2} \sin \frac{\pi k}{6}\right) \sin \frac{\pi k}{2},
\end{aligned}
$$

čia $A_{1}=1 / 3$ ir $A_{2}=2 / 3$ yra magnetovaros dedamųjų santykinès amplitudès.

Furjè eilutès koeficientai apskaičiuojami pagal (3.13) formulę. Furjè eilutè užrašoma tokia forma:

$$
F_{1, \Sigma K}=\sum_{k=0}^{K} b_{1, k} \sin k \phi .
$$




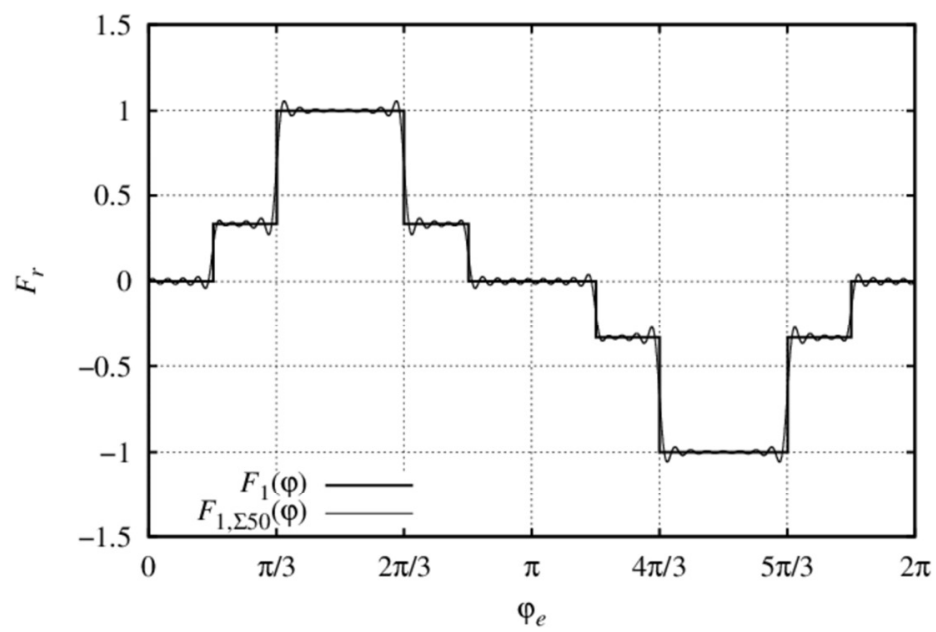

3.18 pav. Sutrumpinto žingsnio apvijos santykinė magnetovaros $F_{1}(\varphi)$ ir jos aproksimacija Furjè eilute $F_{1, \Sigma 50}(\varphi)$

Fig. 3.18. Relative magnetomotive force $F_{1}(\varphi)$ and its approximation by Fourier series $F_{1, \Sigma 50}(\varphi)$ of short pitch coil winding

Funkcijos $F_{l}(\varphi)$ Furjè eilute, kai $k=0-50$ parodyta 3.18 paveiksle ir yra pažymèta $F_{1, \sum 50}(\varphi), \varphi=\sigma_{1} N, N=0-5$.

Sutelktosios dvisluoksnès poliaus žingsnio šešiafazès apvijos magnetovaros $F_{2}(\varphi)$ pasiskirstymas vieno poliaus žingsnio ribose pateiktas 3.19 paveiksle. Funkcijos $F_{2}(\varphi)$ Furjè transformacijos koeficientus apskaičiuosime:

$$
\begin{aligned}
& b_{2, k}=\frac{2 A_{1}}{\pi} \int_{\pi / 4}^{3 \pi / 4} \sin k \phi d \phi+\frac{2 A_{2}}{\pi} \int_{5 \pi / 12}^{7 \pi / 12} \sin k \phi d \phi= \\
& =\frac{4}{\pi k}\left(A_{1} \sin \frac{\pi k}{4}+A_{2} \sin \frac{\pi k}{12}\right) \sin \frac{\pi k}{2},
\end{aligned}
$$

čia $A_{1}=1 / 2$ ir $A_{2}=1 / 2$ yra magnetovaros dedamųjų santykinès amplitudès.

Furjè transformacija gali būti užrašyta ir tokia forma:

$$
F_{2, \Sigma K}=\sum_{k=0}^{K} b_{2, k} \sin k \phi .
$$


Funkcijos $F_{2}(\varphi)$ Furjè eilute, kai $k=0-50$ parodyta 3.19 paveiksle ir yra pažymèta $F_{2, \sum 50}(\varphi), \varphi=\sigma_{2} N, N=0-6$.

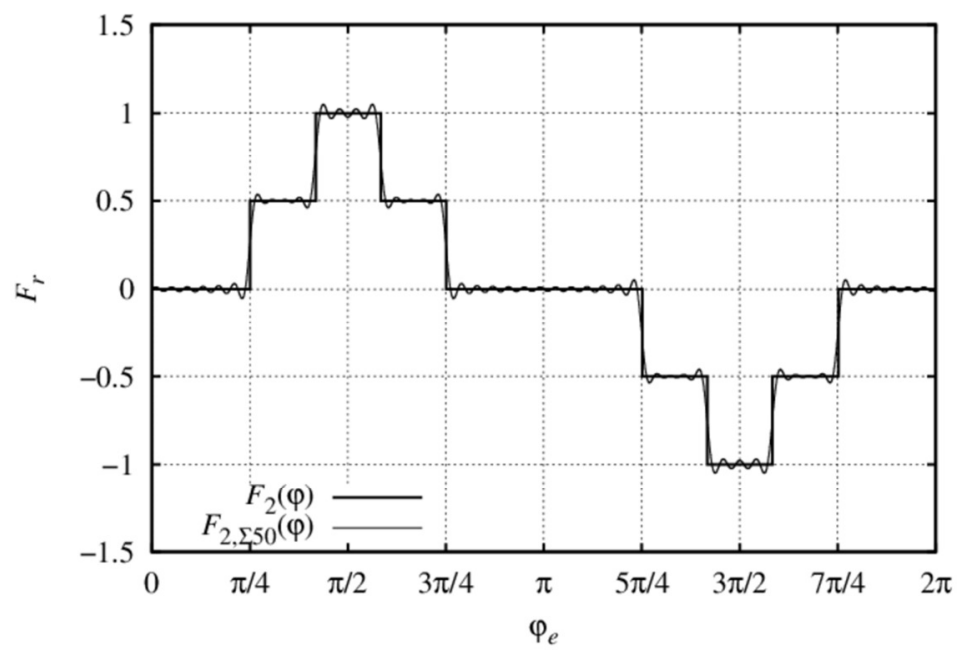

3.19 pav. Poliaus žingsnio apvijos santykinė magnetovaros $F_{2}(\varphi)$ ir jos aproksimacija Furje eilute $\mathrm{F}_{2,550}(\varphi)$

Fig. 3.19. Relative magnetomotive force $\mathrm{F}_{2}(\varphi)$ and its approximation by Fourier series $\mathrm{F}_{2, \Sigma 50}(\varphi)$ of full pitch coil winding

Magnetovaros analizė papildomai suteikia žinių ir apie oro tarpe atsirandančias aukštesniąsias harmonikas.

Lyginant magnetovaros $F_{2}(\varphi) k$-tosios harmonikos amplitudę $b_{2 k}$ su magnetovaros $F_{1}(\varphi) \quad k$-tosios harmonikos amplitude $b_{1 k}$, jų skirtumas procentais:

$$
\delta_{k}=\frac{\left|b_{2, k}\right|-\left|b_{1, k}\right|}{b_{1, k}} 100 \% .
$$

Sutelktosios dvisluoksnès sutrumpinto žingsnio šešiafazès apvijos atveju magnetovaros pirmoji harmonika yra 22 procentais didesnè, nei sutelktosios dvisluoksnès poliaus žingsnio šešiafazės apvijos. Išraiškų (3.13) ir (3.14) analizė rodo, kad sutelktosios dvisluoksnès sutrumpinto žingsnio šešiafazès apvijos atveju pirmoji harmonika apytiksliai lygi 0,8, o pilnutinio žingsnio apvijos atveju ji yra mažesne ir pasiekia 0,6 vertę. Todèl galima daryti išvadą, kad 
šešiafazio variklio sutelktoji dvisluoksnè sutrumpinto žingsnio apvija pasižymės didesniu efektyvumu už sutelktają dvisluoksnę poliaus žingsnio apviją.

Atlikus analizę pagal (3.13) ir (3.15) išraiškas nustatyta, kad abiejų apvijų lyginès harmonikos yra lygios nuliui.

Sutelktosios dvisluoksnès sutrumpinto žingsnio šešiafazès ir sutelktosios dvisluoksnès poliaus žingsnio šešiafazès apvijų magnetovaros spektrai pateikti 3.20 ir 3.21 paveiksluose.

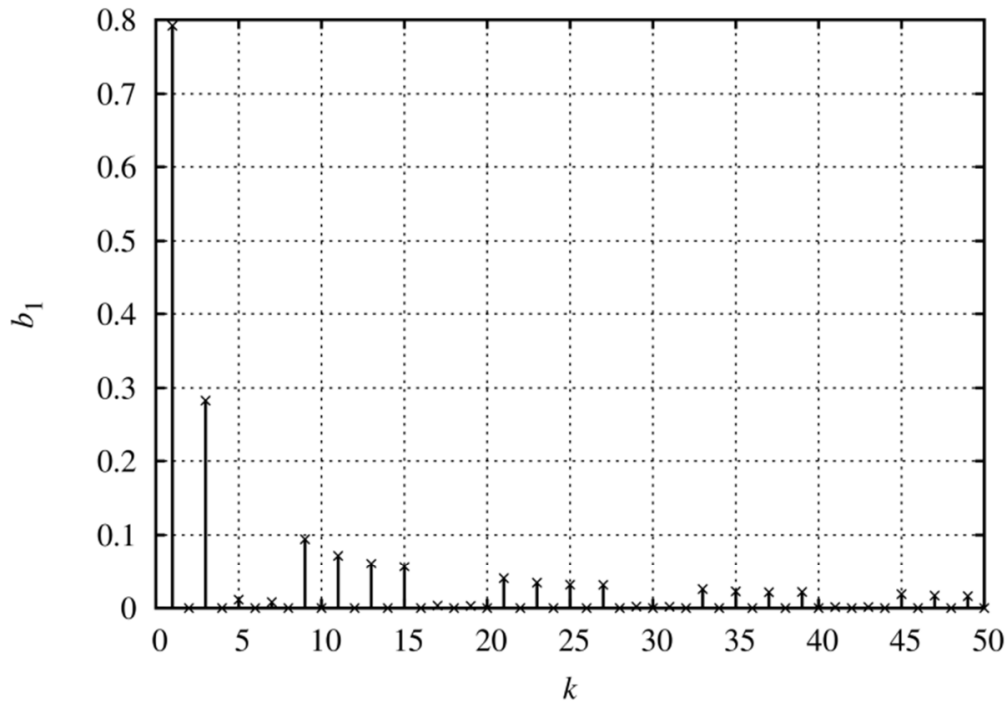

3.20 pav. Sutelktosios dvisluoksnès sutrumpinto žingsnio šešiafazės apvijos magnetovaros harmonikos spektras

Fig. 3.20. The spectrum of magnetomotive force harmonics of short pitch coil six phase winding

Nagrinejjant duomenis, pateiktus 3.20 ir 3.21 paveiksluose matyti, kad sutelktosios dvisluoksnès poliaus žingsnio šešiafazès apvijos ir sutelktosios dvisluoksnès sutrumpinto žingsnio šešiafazès apvijos magnetovarų nelyginių harmonikų skirtumas yra didesnis už nulį: $\left|b_{2,3}\right|-\left|b_{1,3}\right|>0$. Tai rodo, kad sutelktosios dvisluoksnès pilnutinio žingsnio šešiafazès apvijos nelyginès magnetovaros harmonikos turi didesnę amplitudę, negu sutrumpinto žingsnio apvijos nelyginès magnetovaros harmonikos. Atsižvelgiant ị tai, kad aukštesnès harmonikos didina momento osciliacijas ir šilumos nuostolius galima teigti, kad 
sutelktoji dvisluoksnè sutrumpinto žingsnio šešiafazè apvija pasižymi didesniu efektyvumu, negu sutelktoji dvisluoksnè poliaus žingsnio šešiafazė apvija.

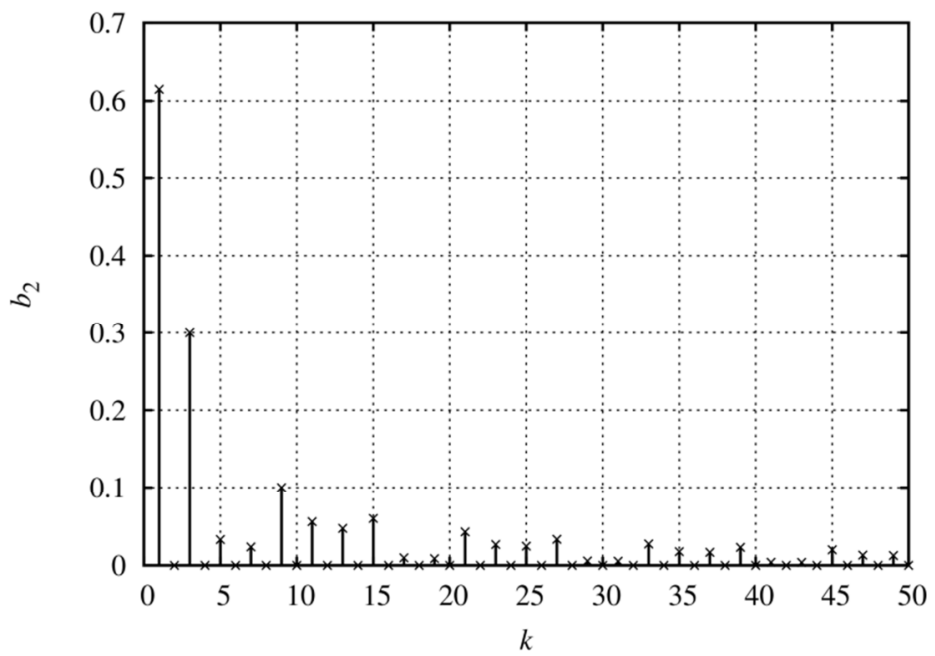

3.21 pav. Sutelktosios dvisluoksnès poliaus žingsnio šešiafazės apvijos magnetovaros harmoniku spektras

Fig. 3.21. The spectrum of magnetomotive force harmonics of full pitch coil six phase winding

Harmonikos amplitudžių skirtumo $\delta_{k}$ priklausomybè nuo harmonikos eilès numerio pateikta 3.22 paveiksle. Sutelktosios dvisluoksnès pilnutinio žingsnio šešiafazès apvijos pirmoji magnetovaros harmonika yra 22 procentais mažesnè už sutelktosios dvisluoksnès sutrumpinto žingsnio šešiafazès apvijos pirmają harmoniką, tačiau trečioji, penktoji ir devintoji harmonikos yra didesnès, bet neviršija 5 procentų. Vienuoliktoji ir tryliktoji harmonikos yra mažesnès ir apytiksliai siekia 2 procentus.

Apibendrinant galima teigti, kad sutelktoji dvisluoksnè sutrumpinto žingsnio apvija pasižymi didesniu efektyvumu negu sutelktoji dvisluoksnè pilnutinio žingsnio apvija.

Tolimesniame etape, atsižvelgiant $i$ analizès rezultatus, buvo pagamintas eksperimentinis variklis turintis sutelktąją dvisluoksnę sutrumpinto žingsnio šešiafazę apviją. 3.23 ir 3.24 paveiksluose pateiktos šio eksperimentinio variklio statoriaus nuotraukos. 


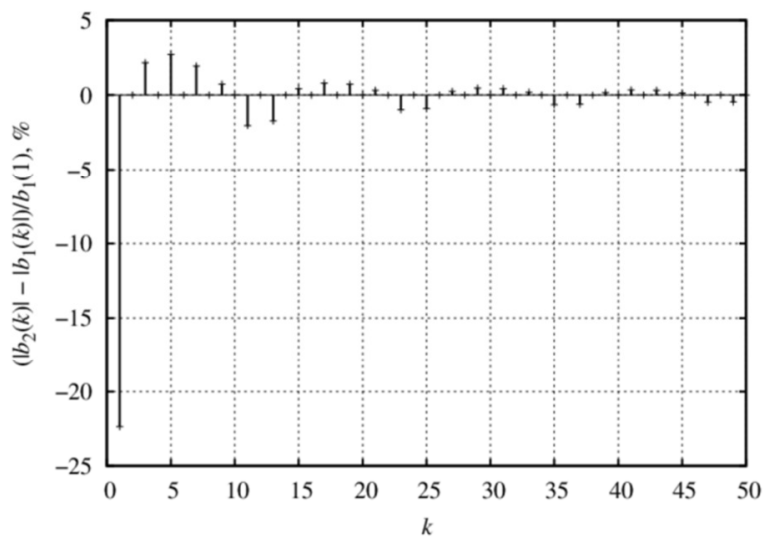

3.22 pav. Harmonikos amplitudžių skirtumo $\delta_{k}$ priklausomybė nuo harmonikos eilès numerio $k$

Fig. 3.22. Dependence of harmonic amplitude difference $\delta_{k}$ against harmonic number $k$

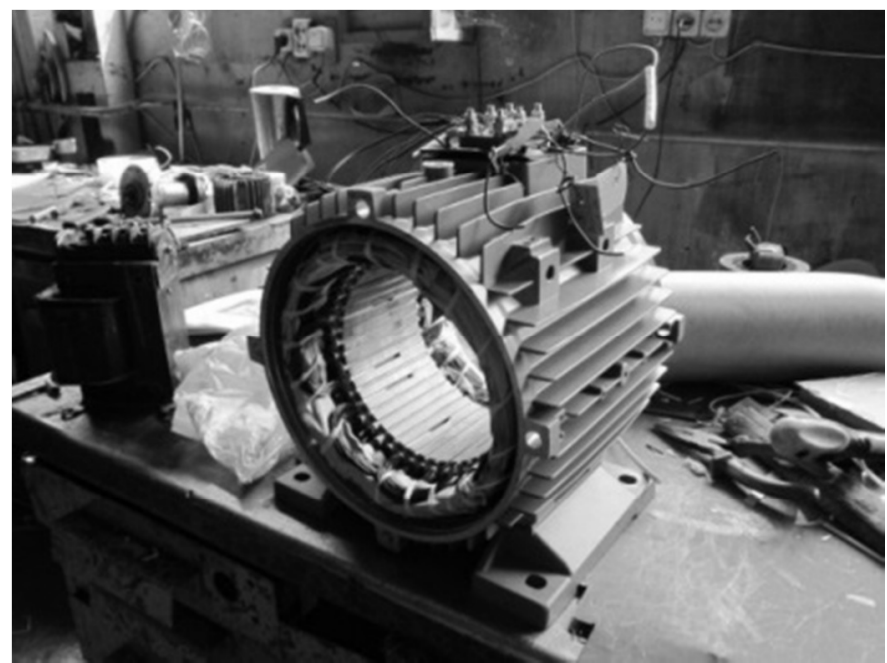

3.23 pav. Eksperimentinio variklio statorius turintis dvisluoksnę sutrumpinto žingsnio šešiafazę apviją

Fig. 3.23. Experimental six phase induction motor stator with concentrated double layer short pitch coil winding

Eksperimentinio asinchroninio variklio statoriaus apvijos kiekvienoje sekcijoje buvo suklota 160 vijų, kurių laido skersmuo $0,4 \mathrm{~mm}$. Šešiafazis 
asinchroninis variklis, turintis sutelktają dvisluoksnę sutrumpinto žingsnio šešiafazę apviją, buvo pagamintas ir išbandytas.

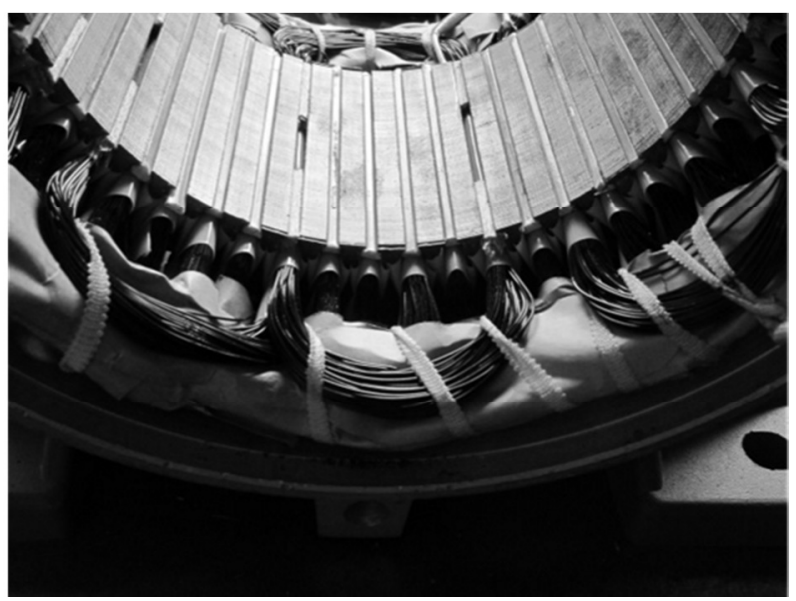

3.24 pav. Eksperimentinio variklio statorius turintis dvisluoksnę sutrumpinto žingsnio šešiafazę apviją

Fig. 3.24. Experimental six phase induction motor stator with concentrated double layer short pitch coil winding

\section{3. Šešiafazio asinchroninio variklio imitaciniai tyrimai}

Šešiafazio asinchroninio variklio imitacinio modelio pagal statoriaus ir rotoriaus sroves sudarymas aprašytas 2.1 skyriuje.

Modeliuojamojo variklio parametrai pateikti 3.1 lenteleje.

3.1 lentelè. Modeliuojamojo variklio parametrai

Table 3.1. Parameters of simulated motor

\begin{tabular}{|c|c|c|c|c|c|c|c|}
\hline Parametras & $\begin{array}{c}U, \\
\mathrm{~V}\end{array}$ & $\begin{array}{c}P_{t . v,}, \\
\mathrm{~W}\end{array}$ & $\begin{array}{c}I, \\
\mathrm{~A}\end{array}$ & $\begin{array}{c}\Phi, \\
\mathrm{rad} / \mathrm{s}\end{array}$ & $\begin{array}{c}\text { Polių } \\
\text { poru } \\
\text { skaičius }\end{array}$ & $\cos \varphi$ & $\begin{array}{c}J, \\
\mathrm{~kg} \cdot \mathrm{m}^{2}\end{array}$ \\
\hline Vertė & 225 & 218 & 0,2 & 78 & 4 & 0,81 & 0,0298 \\
\hline Parametras & $\begin{array}{c}R_{\mathrm{s}}, \\
\Omega\end{array}$ & $\begin{array}{c}L_{\mathrm{ls}}, \\
\mathrm{mH}\end{array}$ & $\begin{array}{c}L_{\mathrm{m}}, \\
\mathrm{mH}\end{array}$ & $\begin{array}{c}L_{\mathrm{lm}}, \\
\mathrm{mH}\end{array}$ & $\begin{array}{c}R_{\mathrm{r}}, \\
\Omega\end{array}$ & $\begin{array}{c}L_{\mathrm{lr}} \\
\mathrm{mH}\end{array}$ & $\begin{array}{c}L_{\mathrm{r}} \\
\mathrm{mH}\end{array}$ \\
\hline Vertė & 68 & 70 & 295 & 70 & 4,5 & 115 & 324 \\
\hline
\end{tabular}


Pirmojo imitacinio bandymo metu, nustatyta maitinimo įtampos verte yra lygi $200 \mathrm{~V}$. Gautos momento ir greičio pereinamujų vyksmų charakteristikos pateiktos atitinkamai 3.25 ir 3.26 paveiksluose.

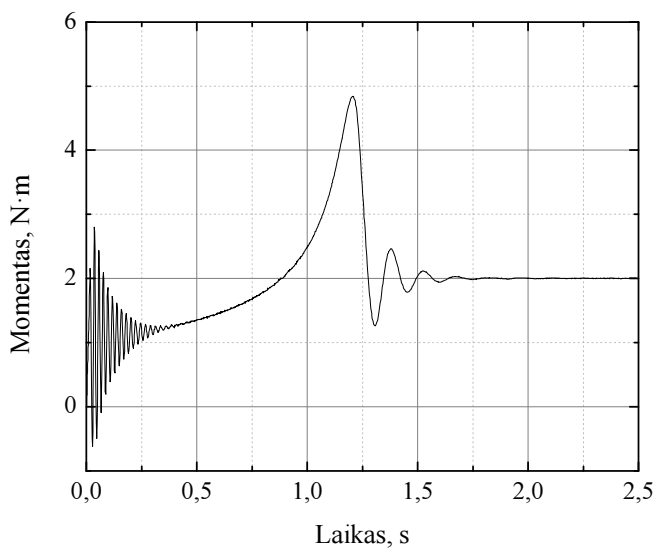

3.25 pav. Šešiafazio asinchroninio variklio paleidimo momento pereinamasis vyksmas, kai maitinimo itampa lygi $200 \mathrm{~V}$

Fig. 3.25. Torque characteristic of six phase induction motor, at $200 \mathrm{~V}$ supply voltage

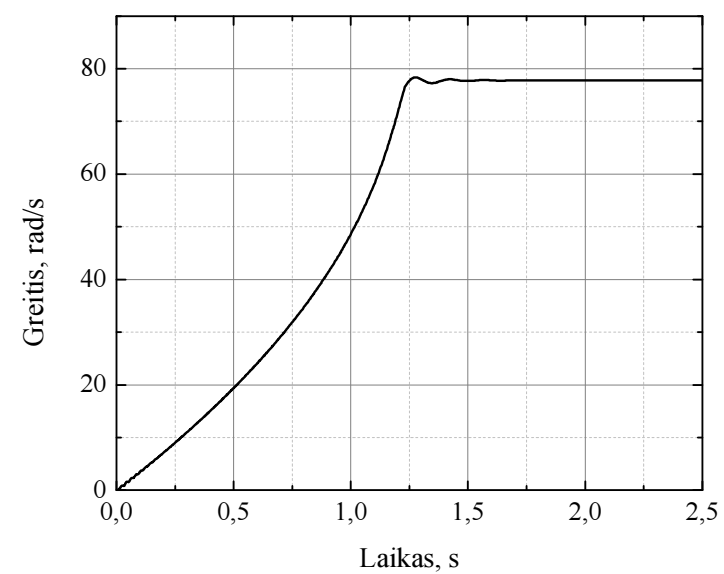

3.26 pav. Šešiafazio asinchroninio variklio paleidimo greičio pereinamasis vyksmas, kai maitinimo itampa lygi $200 \mathrm{~V}$

Fig. 3.26. Speed characteristic of six phase induction motor, at $200 \mathrm{~V}$ supply voltage 
Iš 3.25 paveikslo matyti, kad momento vertè nusistovi per 1,65 s. Didžiausioji jo vertè lygi $4,8 \mathrm{~N} \cdot \mathrm{m}$. Nusistovèjęs sukimo momentas $2 \mathrm{~N} \cdot \mathrm{m}$, nes variklis paleidžiamas apkrautas $2 \mathrm{~N} \cdot \mathrm{m}$ apkrovą.

Iš 3.26 paveikslo matyti, kad greitis nusistovi per $1,65 \mathrm{~s}$, o nusistovejjusi jo vertè yra lygi $78 \mathrm{rad} / \mathrm{s}$. Greičio nusistovejjimo trukmė yra ta pati kaip ir momento nusistovejjimo trukmè.

3.27 ir 3.28 paveiksluose yra pateiktos šešiafazio asinchroninio variklio imitacinio bandymo charaktersitikos, kai variklis maitinamas $200 \mathrm{~V}$ itampa ir prie jo rotoriaus prijungiamos skirtingos vertes apkrovos. Jos vaizduoja momento ir greičio pereinamuosius vyksmus, kai šešiafazis asichroninis variklis paleidžiamas apkrautas $2 \mathrm{~N} \cdot \mathrm{m}$ apkrova. Praejjus dviems sekundèms po paleidimo variklio velenas papildomai apkraunamas $1 \mathrm{~N} \cdot \mathrm{m}$ apkrova. Praejus trims sekundèms apkrova padidinama dar $1 \mathrm{~N} \cdot \mathrm{m}$, o po keturių sekundžių apkrova atjungiama.

Iš 3.27 paveikslo matyti, kad momento virpesiai prijungus apkrovas antrają ir trečiają sekundes trunka 0,3 sekundès ir po to nusistovi ties apkrovos verte. Atjungus apkrovą, momentas nusistovi ties verte lygia 0 per 0,5 sekundès. 3.28 paveiksle pateiktas greičio pereinamasis vyksmas kartoja momento pereinamaji vyksmą. Pasiekiama didžiausia greičio verte yra tuomet, kai atjungiama apkrova ir ji lygi $80 \mathrm{rad} / \mathrm{s}$.

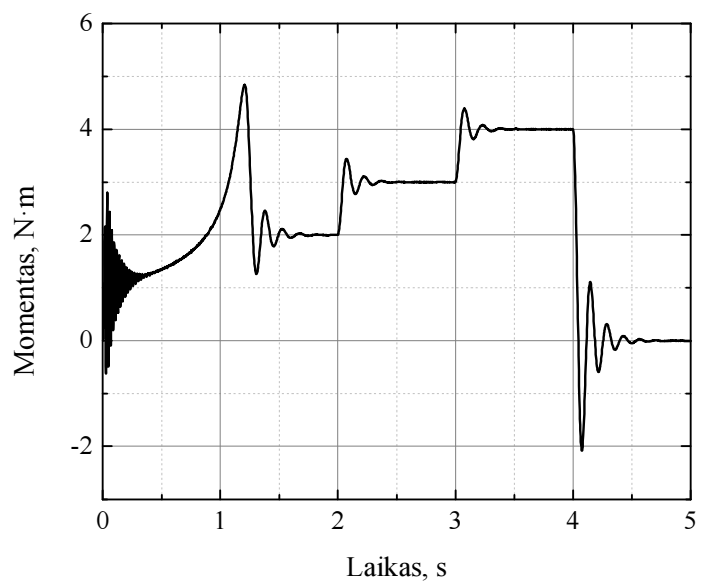

3.27 pav. Apkrauto šešiafazio asinchroninio variklio momento pereinamasis vyksmas, kai maitinimo ịtampa lygi $200 \mathrm{~V}$

Fig. 3.27. Torque characteristic of six phase induction motor with connected load, at 200 V supply voltage 


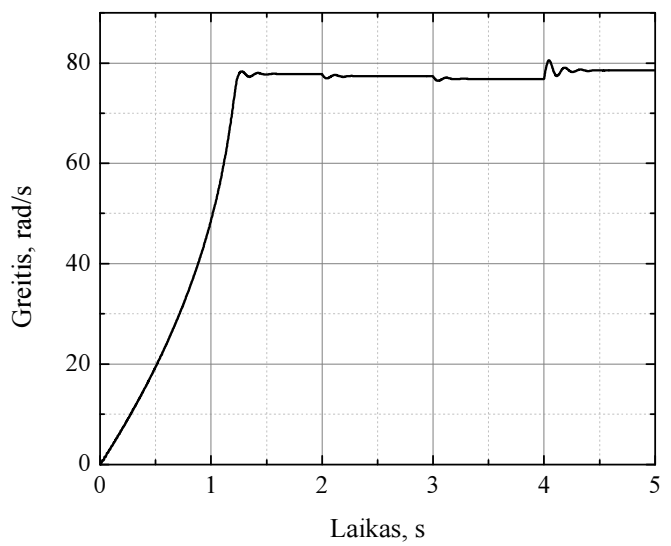

3.28 pav. Apkrauto šešiafazio asinchroninio variklio paleidimo greičio pereinamasis vyksmas, kai maitinimo ịtampa lygi $200 \mathrm{~V}$

Fig. 3.28. Speed characteristic of six phase induction motor with connected load, at 200 V supply voltage

Analogiški imitaciniai bandymai buvo atlikti esant $225 \mathrm{~V}$ maitinimo itampai. Gautos momento ir greičio pereinamujų vyksmų kreivès pateiktos 3.29 ir 3.30 paveiksluose.

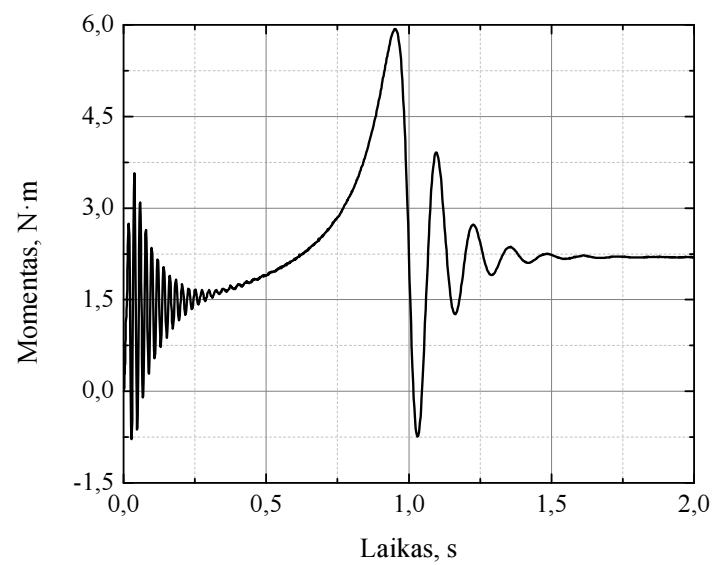

3.29 pav. Šešiafazio asinchroninio variklio momento pereinamasis vyksmas, kai maitinimo itampa lygi $225 \mathrm{~V}$

Fig. 3.29. Torque characteristic of six phase induction motor, at $225 \mathrm{~V}$ supply voltage 


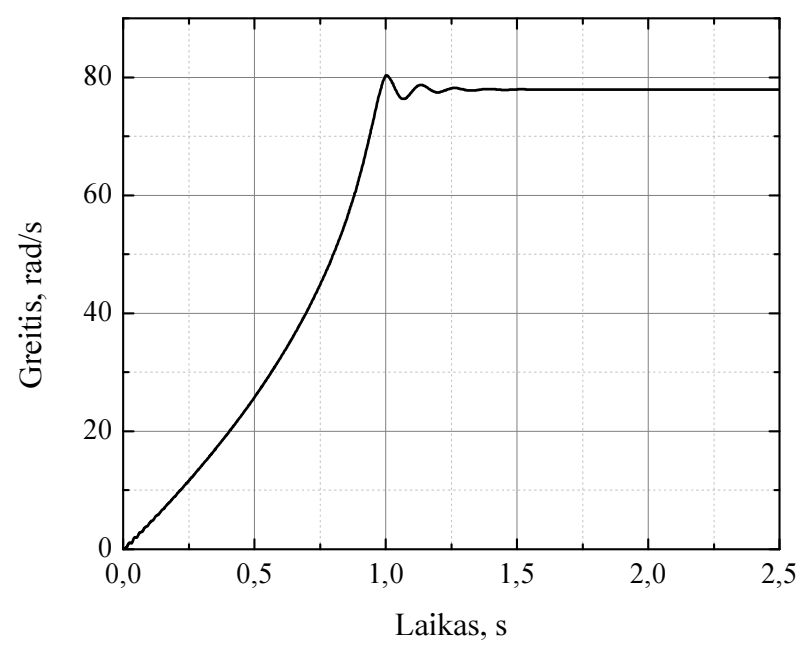

3.30 pav. Šešiafazio asinchroninio variklio greičio pereinamasis vyksmas, kai maitinimo itampa lygi $225 \mathrm{~V}$

Fig. 3.30. Speed characteristic of six phase induction motor, at $225 \mathrm{~V}$ supply voltage

Maitinant varikli $225 \mathrm{~V}$ ịtampa momento verte nusistovi greičiausiai, per 1,3 sekundès. Pasiekiama didžiausia maksimaliojo momento verte lygi $6 \mathrm{~N} \cdot \mathrm{m}$. Momentas nusistovi ties $2,2 \mathrm{~N} \cdot \mathrm{m}$ verte, nes jis paleidžiamas su $2,2 \mathrm{~N} \cdot \mathrm{m}$ vertès apkrova.

Iš 2.29 ir 3.30 paveikslų matyti, kad greičio kreivè atkartoja momento charakteristiką. Paleidžiant variklį, kai jis maitinamas $225 \mathrm{~V}$ ịtampa, jo rotoriaus greitis pasiekia didžiausią $80 \mathrm{rad} / \mathrm{s}$ vertę,o po $1,3 \mathrm{~s}$ jis nusistovi ties $78 \mathrm{rad} / \mathrm{s}$ verte.

3.31 ir 3.32 paveiksluose pateiktos charakteristikos vaizduoja momento ir greičio pereinamuosius vyksmus, kuomet šešiafazis asichroninis variklis paleidžiamas apkrautas $2,2 \mathrm{~N} \cdot \mathrm{m}$ apkrova. Praejus dviems sekundèms po paleidimo variklio velenas papildomai apkraunamas $1 \mathrm{~N} \cdot \mathrm{m}$ apkrova. Praejjus trims sekundèms apkrova padidinama dar $1 \mathrm{~N} \cdot \mathrm{m}$, o po keturių sekundžių apkrova atjungiama.

Iš 3.31 paveikslo matyti, kad momento virpesiai prijungus apkrovas antrają ir trečiąą sekundès trunka 0,25 sekundès ir po to nusistovi ties apkrovos verte. Atjungus apkrovą, momentas nusistovi ties 0 per 0,4 sekundès.

Iš 3.32 paveikslo matyti, kad apkraunant varikli pasiekiamas didžiausias 81 $\mathrm{rad} / \mathrm{s}$ greitis. 


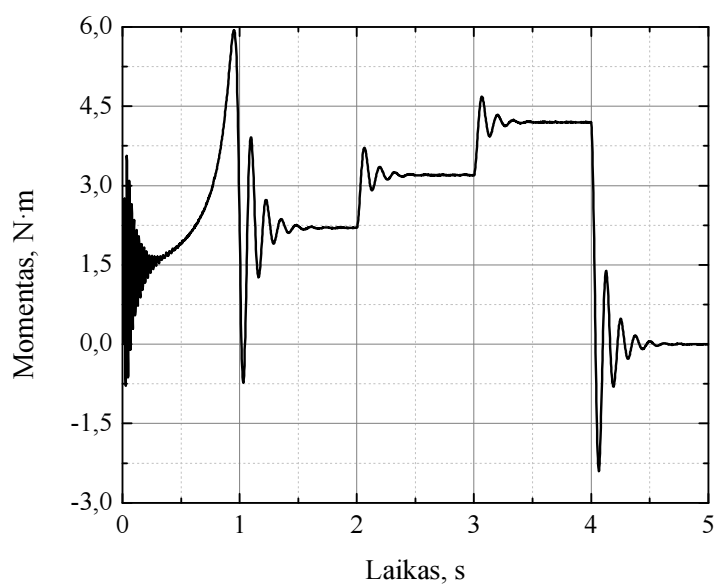

3.31 pav. Apkrauto šešiafazio asinchroninio variklio momento pereinamasis vyksmas, kai maitinimo itampa lygi $225 \mathrm{~V}$

Fig. 3.31. Torque characteristic of six phase induction motor with connected load, at 225 V supply voltage

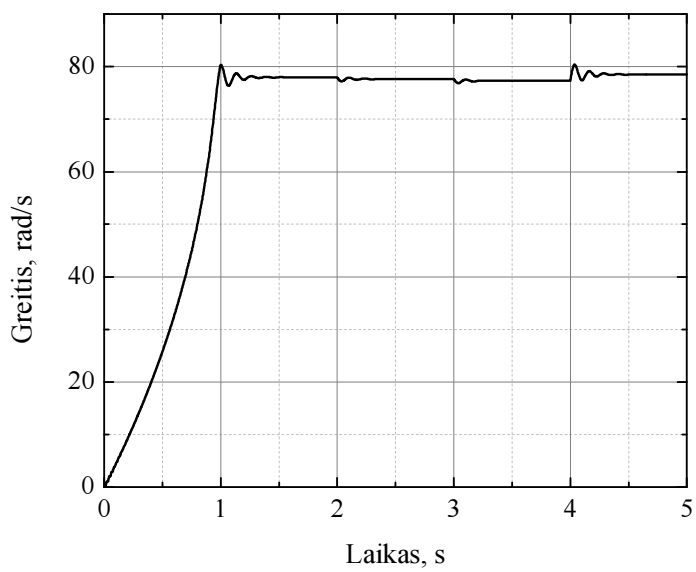

3.32 pav. Apkrauto šešiafazio asinchroninio variklio greičio pereinamasis vyksmas, kai maitinimo įtampa lygi $225 \mathrm{~V}$

Fig. 3.32. Speed characteristic of six phase induction motor with connected load, at 225

V supply voltage 


\subsection{Bandymų stendo aprašymas}

Šešiafazio asinchroninio variklio charakteristiku tyrimui Vilniaus Gedimino technikos universiteto Automatikos katedroje sukonstruotas specialus stendas, kurio struktūra pateikta 3.33 paveiksle. Jis susideda iš trijų, maitinamų iš trifazio tinklo, autotransformatorių (1), kurie skirti transformatoriaus (2) maitinimo itampai reguliuoti. Maitinimo transformatorius keičia trifazę tinklo ịtampą i simetrinę šešiafazę, kurios ịtampų fazinis poslinkis yra 60 laipsnių. Eksperimentinis šešiafazis asinchroninis variklis sankabomis (5) yra sujungtas su momento matuokliu (4) ir apkrova (6). Momento matuoklis ir greičio matavimo prietaisas, kitaip tariant dažnio įtampos keitiklis (7), yra maitinami iš nuolatinès įtampos šaltinio (9). Rezultatai matuojami skaitmeniniu oscilografu (8).

Šešiafazio asinchroninio variklio bandymų stendo foto fragmentas pateiktas 3.34 paveiksle.

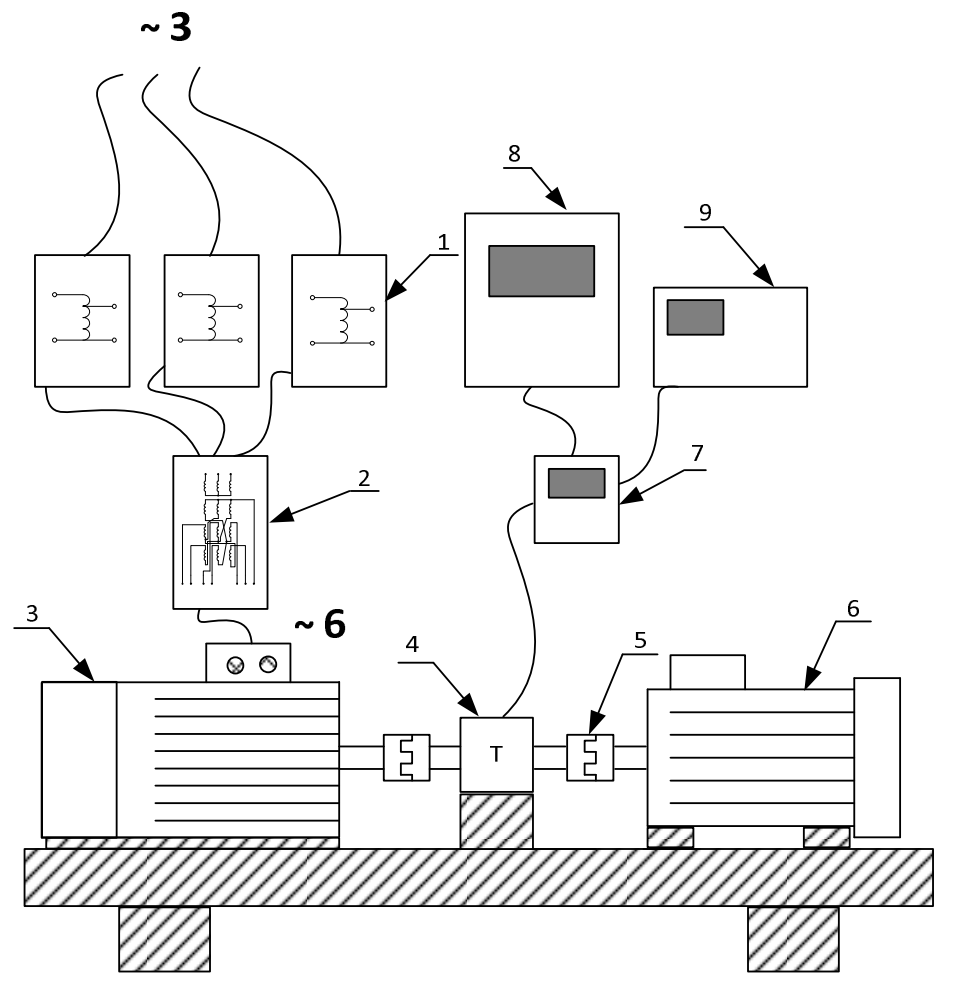

3.33 pav. Šešiafazio asinchroninio variklio bandymų stendo struktūra Fig. 3.33. Structure of the six phase induction motor experimental stand 
Momento matuoklio pagrindiniai parametrai pateikti 3.2 lenteleje. Momento matuoklis turi analogini įtampos išèjimo signalą, kuris yra proporcingas matuojamam momentui. Prijungus oscilografą galima gauti pereinamojo vyksmo kreivę. Momento matuoklis taip pat turi impulsini išèjimo signalą, kurio dažnis yra proporcingas sukimosi greičiui. Matuojant variklio greičio pereinamuosius vyksmus naudojamas papildomas dažnio - itampos keitiklis (Juraitis, 2012). Greičio pereinamieji vyksmai gaunami oscilografu matuojant keitiklio įtampą.

Matavimai buvo atliekami skaitmeniniu oscilografu, kurio dažnių juosta nuo 0 iki $100 \mathrm{MHz}$. Oscilografo jautrumas nuo $2 \mathrm{mV} /$ pad iki $10 \mathrm{~V} /$ pad. Oscilografas turèjo 8 bitu analogini - skaitmenini keitiklį, kuris išèjimo signalą vertè skaičiumi. Per USB jungti oscilografas buvo sujungtas su personaliniu kompiuteriu. Gauti rezultatai buvo perkeliami i kompiuteri ir tvarkomi

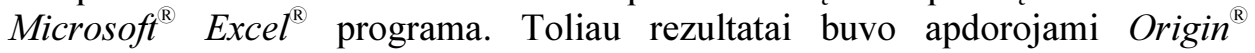
programa.

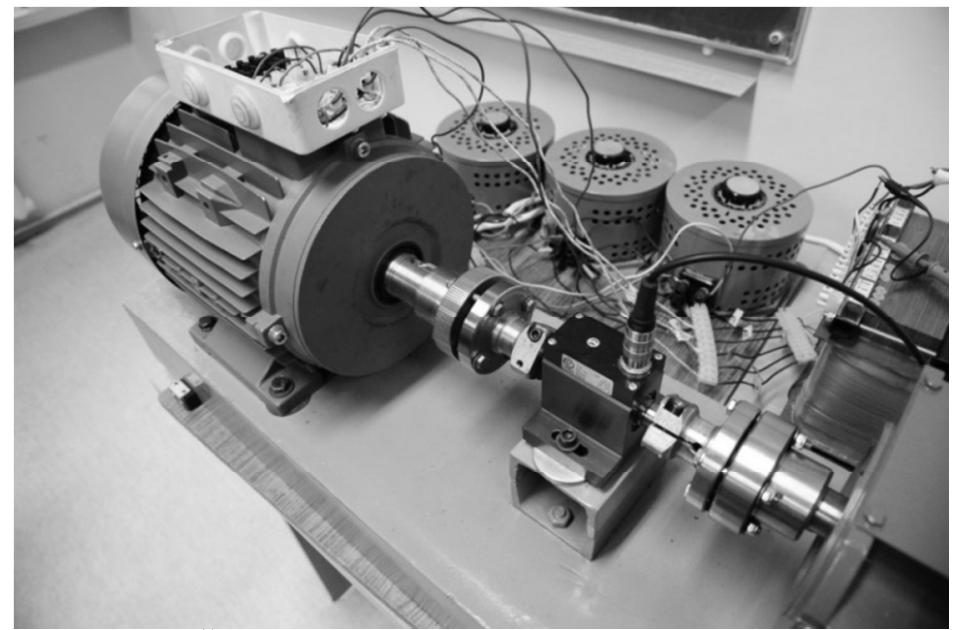

3.34 pav. Šešiafazio asinchroninio variklio bandymų stendas

Fig. 3.34. Experimental stand of the variable speed drive

Variklio greitis $n$ apsisukimais per minutę, bet kuriuo laiko momentu, apskaičiuojamas pagal formulę:

$$
n=\frac{60 f_{s}}{n_{A}},
$$

čia $f_{s}-$ keitiklio impulsų dažnis; $n_{A}-$ keitiklio impulsų skaičius per apsisukimą, lygus 360 . 
3.2 lentelè. Momento matuoklio Lorenz Messtechnik DR-2212 parametrai Table 3.2. Parameters of torque sensor Lorenz Messtechnik DR-2212

\begin{tabular}{|l|c|}
\hline Parametras & Dydis \\
\hline Tikslumo klasė, $\%$ & 0,1 \\
\hline Atsikartojamumas, $\%$ & $\pm 0,02$ \\
\hline Maitinimo ịtampa, $\mathrm{V}$ & $12-28$ \\
\hline Išejimo signalas, $\mathrm{V}$ & \pm 5 \\
\hline Temperatūros diapazonas, ${ }^{\circ} \mathrm{C}$ & nuo +5 iki +45 \\
\hline Matavimo diapazonas, $\mathrm{N} \cdot \mathrm{m}$ & 20 \\
\hline
\end{tabular}

Impulsų dažnis yra nustatomas pagal dažnio - itampos keitiklio itampos rodmenis, kurie matuojami oscilografu. Ryšys tarp impulsų dažnio ir įtampos yra parodytas 3.35 paveiksle.

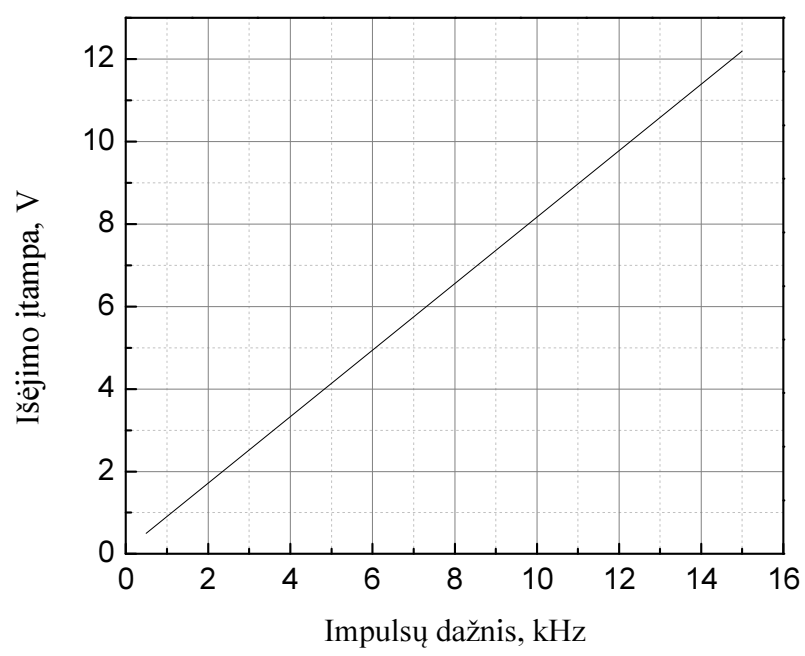

3.35 pav. Greičio matavimo prietaiso charakteristika Fig. 3.35. Characteristic of speed measuring device

Maitinimo transformatoriaus antrinių apvijų jungimo schema pateikta 3.36 paveiksle. Pirmines transformatoriaus apvijas maitinant standartinio trifazio tinklo i̇tampa, transformatoriaus išèjime gaunama šešiafazė itampa, kurios sinusoidžių fazinis poslinkis - 60 laipsnių.

Eksperimentinio šešiafazio asinchroninio variklio parametrai pateikti 3.3 lentelèje. 
3.3 lentelè. Eksperimentinio šešiafazio asinchroninio variklio parametrai

Table 3.3. Parameters of experimental six phase induction motor

\begin{tabular}{|c|c|c|c|c|c|c|c|c|}
\hline Parametras & $\begin{array}{c}U, \\
\mathrm{~V}\end{array}$ & $\begin{array}{c}P_{t . v,}, \\
\mathrm{~W}\end{array}$ & $\begin{array}{c}I, \\
\mathrm{~A}\end{array}$ & $\begin{array}{c}\Phi, \\
\mathrm{rad} / \mathrm{s}\end{array}$ & $\begin{array}{c}\text { Polių poru } \\
\text { skaičius }\end{array}$ & $\cos \varphi^{*}$ & $\begin{array}{c}R_{\mathrm{S}}, \\
\Omega\end{array}$ & $\begin{array}{c}J, \\
\mathrm{~kg} \cdot \mathrm{m}^{2}\end{array}$ \\
\hline Verte & 225 & 218 & 0,2 & 78 & 4 & 0,81 & 68 & 0,0298 \\
\hline
\end{tabular}

* $\cos \varphi$ išmatuotas matuojant itampos ir srovès faziụ kampu skirtumą. Matavimai atlikti oscilografu. Srovei matuoti panaudotas Mastech MS 3302 AC konverteris.

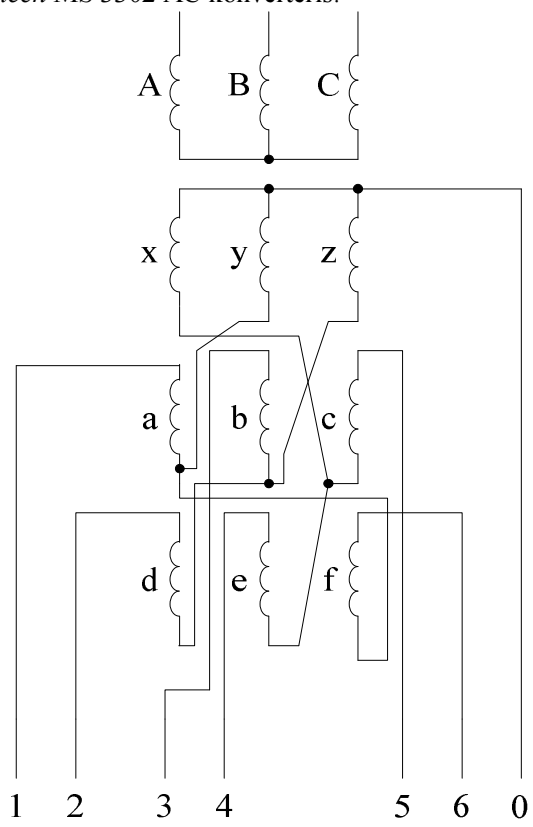

3.36 pav. Maitinimo transformatoriaus antrinių apvijų šešiafazė jungimo schema Fig. 3.36. Secondary winding connection scheme of six phase supply transformer

\section{5. Šešiafazio asinchroninio variklio eksperimentinis tyrimas}

Eksperimentiniams tyrimams buvo keliamas uždavinys ištirti dinamines variklio savybes paleidimo metu ir palyginti jas su imitacinių bandymų rezultatais.

Bandymų metu šešiafazis asinchroninis variklis buvo paleidžiamas esant skirtingoms maitinimo itampu vertems. Jos buvo keičiamos autotransformatoriais nustatant reikalingą itampą kiekvienai statoriaus fazinei 
apvijai. Eksperimento metu oscilografu buvo matuojamos jutiklių įtampų verčių priklausomybės nuo laiko. Jas perskaičiavus gautos momento ir greičio pereinamujų vyksmų kreivès.

Pirmojo bandymo metu šešiafazis asinchroninis variklis buvo paleidžiamas, esant $75 \mathrm{~V}$ maitinimo itampai. Gauta sukimo momento pereinamojo vyksmo paleidimo metu kreivè pateikta 3.37 paveiksle. Iš jos matoma, kad variklis paleidžiamas be didelių momento svyravimų. Tai lemia didelè statoriaus varža. Momento pereinamais vyksmas trunka 4,3 s kol pasiekiama nusistovejjusi 1,3 $\mathrm{N} \cdot \mathrm{m}$ momento verte. Didžiausia pasiekiama momento verte lygi $1,4 \mathrm{~N} \cdot \mathrm{m}$. Momentas nusistovi ties $1,3 \mathrm{~N} \cdot \mathrm{m}$ verte, nes eksperimentinio variklio velenas yra sujungtas su nuolatinès srovès generatoriumi, kurio trintis ir variklio bei generatoriaus ventiliatoriai sukelia $1,3 \mathrm{~N} \cdot \mathrm{m}$ apkrovą.

Antrojo bandymo metu šešiafazis asinchroninis variklis buvo paleidžiamas, esant $100 \mathrm{~V}$ maitinimo ịtampos vertei. Gauta sukimo momento pereinamojo vyksmo paleidimo metu kreivè pateikta 3.38 paveiksle.

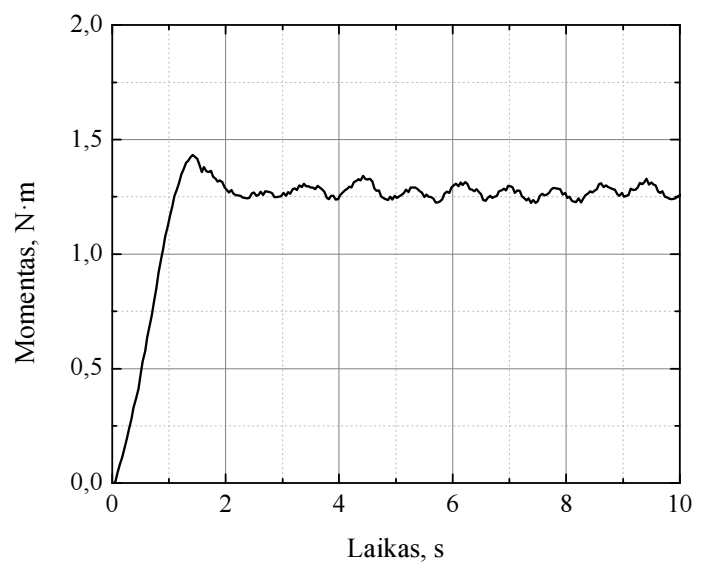

3.37 pav. Šešiafazio asinchroninio variklio paleidimo momento pereinamasis vyksmas, kai maitinimo itampa lygi $75 \mathrm{~V}$

Fig. 3.37. Torque characteristic of six phase induction motor, at $75 \mathrm{~V}$ supply voltage

Iš 3.38 paveikslo matyti, kad momentas nusistovi per 29 s. Nusistovejusi momento verte yra $1,3 \mathrm{~N} \cdot \mathrm{m}$, o didžiausia pasiekiama paleidimo metu, lygi 2,2 $\mathrm{N} \cdot \mathrm{m}$.

Trečiojo bandymo metu variklis paleidžiamas statoriaus apvijas maitinant $125 \mathrm{~V}$ itampa. Gauta variklio paleidimo metu momento pereinamojo vyksmo kreivė pateikta 3.39 paveiksle. Iš paveikslo matyti, kad momentas nusistovi per 7,5 s. Dèl aukščiau minètos trinties apkrovos momentas nusistovi ties $1,5 \mathrm{~N} \cdot \mathrm{m}$. 
Lyginant variklio paleidimo metu gautas momento pereinamojo vyksmo kreives, kai variklis maitinamas $100 \mathrm{~V}$ ir $125 \mathrm{~V}$ itampa, matoma, kad didžiausia momento verte esant $125 \mathrm{~V}$ įtampai išauga 1,3 karto ir yra $3 \mathrm{~N} \cdot \mathrm{m}$.

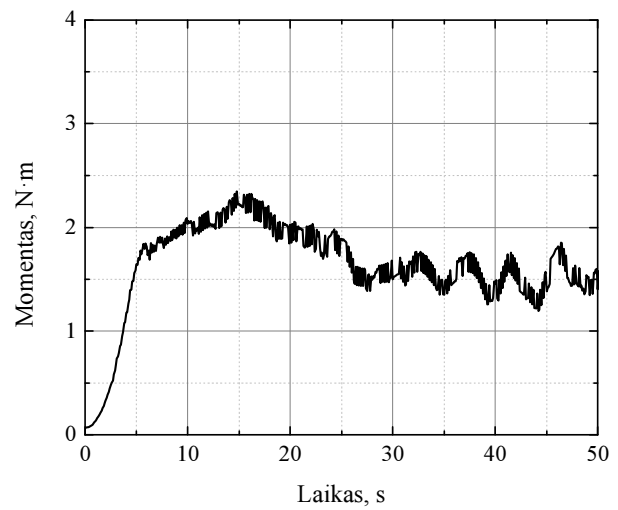

3.38 pav. Šešiafazio asinchroninio variklio paleidimo momento pereinamasis vyksmas, kai maitinimo ittampa lygi $100 \mathrm{~V}$

Fig. 3.38. Torque characteristic of six phase induction motor, at $100 \mathrm{~V}$ supply voltage

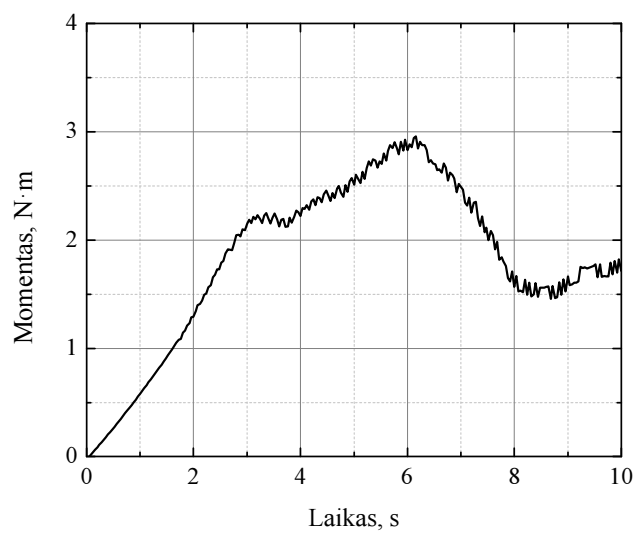

3.39 pav. Šešiafazio asinchroninio variklio paleidimo momento pereinamasis vyksmas, kai maitinimo itampa lygi $125 \mathrm{~V}$

Fig. 3.39. Torque characteristic of six phase induction motor, at $125 \mathrm{~V}$ supply voltage 


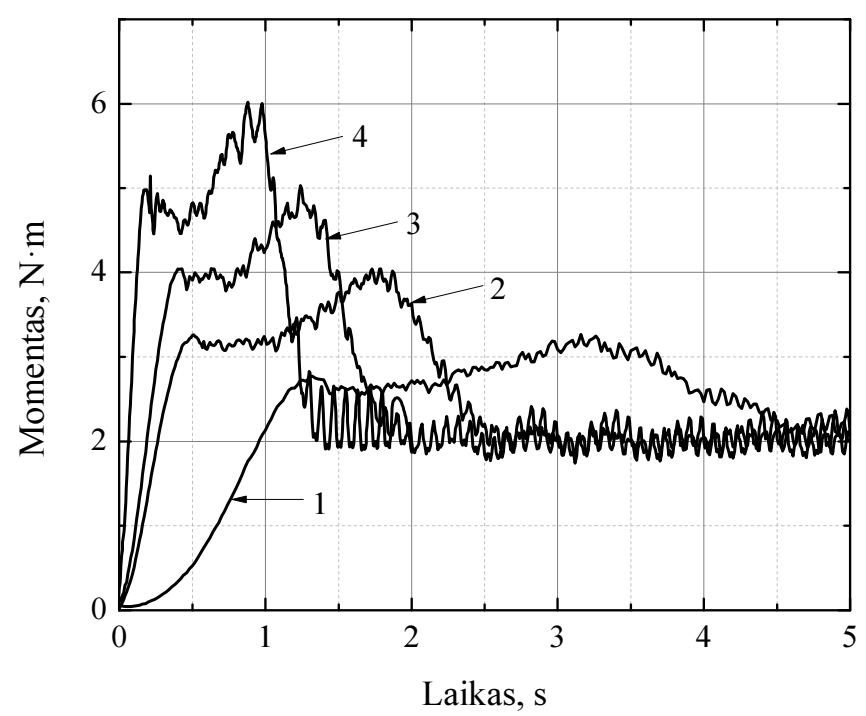

3.40 pav. Šešiafazio asinchroninio variklio paleidimo momento pereinamasis vyksmas, kai maitinimo itampa lygi: $1-150 \mathrm{~V} ; 2-175 \mathrm{~V} ; 3-200 \mathrm{~V} ; 4-225 \mathrm{~V}$

Fig. 3.40. Torque characteristic of six phase induction motor. Supply voltage is: $1-150$ $\mathrm{V} ; 2-175 \mathrm{~V} ; 3-200 \mathrm{~V} ; 4-225 \mathrm{~V}$

Ketvirtojo, penktojo, šeštojo ir septintojo bandymų, esant $2 \mathrm{~N} \cdot \mathrm{m}$ apkrovai, rezultatai pateikti 3.40 paveiksle. Iš 3.40 paveikslo matyti, kad šešiafazị asinchronini varikli maitinant $150 \mathrm{~V}$ ịtampa, variklio paleidimo metu momento pereinamieji vyksmai trunka $3,8 \mathrm{~s}$. Praèjus $3,2 \mathrm{~s}$ nuo paleidimo pradžios pasiekiama didžiausia momento vertè, kuri lygi $3,2 \mathrm{~N} \cdot \mathrm{m}$. Momentas po $3,8 \mathrm{~s}$ nusistovi ties apkrovos momento verte, kuri šiuo atveju lygi $2 \mathrm{~N} \cdot \mathrm{m}$. Ši vertè, lyginant su prieš tai nagrinètu atveju, yra padidejjusi $0,5 \mathrm{~N} \cdot \mathrm{m}$. Apkrovos momento pokytị lèmé variklio ir prijungto generatoriaus ventiliatorių padidejusi pasipriešinimo jèga.

Padidinus variklio maitinimo įtampą iki $175 \mathrm{~V}$, momento vertè nusistovi dar greičiau, per 2,4 s. Maksimali momento vertè lygi $4 \mathrm{~N} \cdot \mathrm{m}$ ir pasiekiama per 1,7 $\mathrm{s}$.

Varikli maitinant $200 \mathrm{~V}$ ịtampa momento verte nusistovi per $1,7 \mathrm{~s}$. Maksimali momento verte lygi $5 \mathrm{~N} \cdot \mathrm{m}$, o momentas nusistovi ties $2 \mathrm{~N} \cdot \mathrm{m}$ verte.

Paskutiniojo bandymo metu variklis buvo paleidžiamas ji maitinant $225 \mathrm{~V}$ itampa. Šiuo atveju momento vertè nusistovi greičiausiai, per 1,25 s. Pasiekiama didžiausia momento vertè lygi $6 \mathrm{~N} \cdot \mathrm{m}$. Momentas nusistovi ties $2,2 \mathrm{~N} \cdot \mathrm{m}$ verte. 
Kitų bandymų metu naudojant greičio matavimo įrangą buvo išmatuotos jutiklio įtampų priklausomybès nuo laiko. Itampų vertės perskaičiuotos į greičio vertes ir tokiu būdu gautos variklio greičio pereinamojo vyksmo kreivès. Eksperimentiniai matavimai buvo atlikti esant tokioms pačioms maitinimo itampos vertems, kaip ir momento atveju: $75 \mathrm{~V}, 100 \mathrm{~V}, 125 \mathrm{~V}, 150 \mathrm{~V}, 200 \mathrm{~V}$ ir $225 \mathrm{~V}$.

Pirmojo bandymo metu šešiafazis asinchroninis variklis buvo paleidžiamas, esant maitinimo itampai $75 \mathrm{~V}$. Gauta paleidimo metu greičio pereinamojo vyksmo kreivè pateikta 3.41 paveiksle.

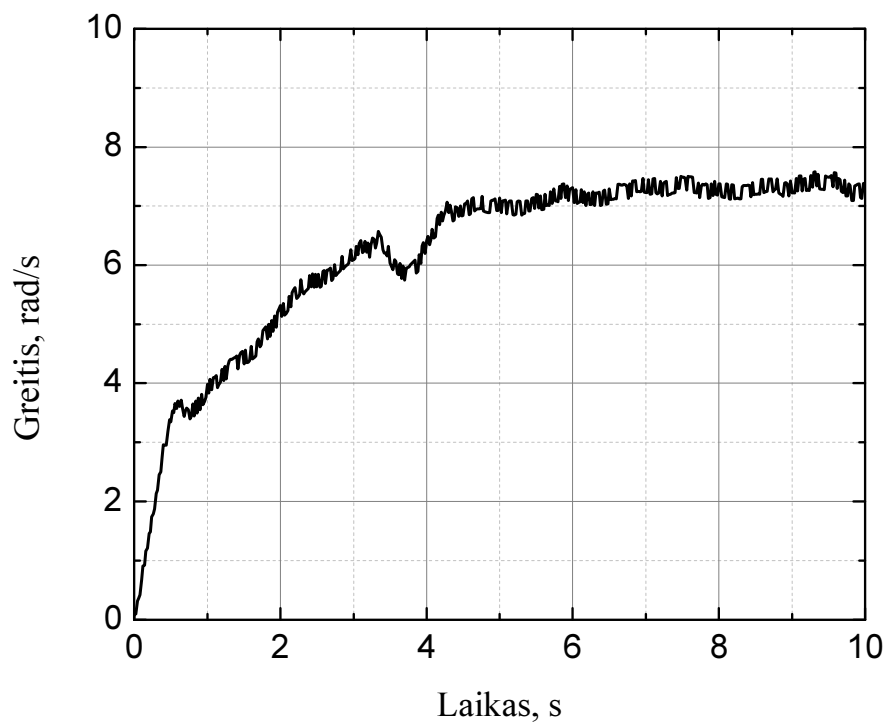

3.41 pav. Šešiafazio asinchroninio variklio paleidimo greičio pereinamasis vyksmas, kai maitinimo ittampa lygi $75 \mathrm{~V}$

Fig. 3.41. Speed characteristic of six phase induction motor, at $75 \mathrm{~V}$ supply voltageV

Iš 3.41 paveikslo matyti, kad šešiafazio asinchroninio variklio greitis paleidimo metu nusistovi per $4,3 \mathrm{~s}$, kai jo rotorius pasiekia $7 \mathrm{rad} / \mathrm{s}$ greitị. Maža maitinimo ịtampa lemia nedideli rotoriaus sukimosi greitị, didelį slydimą, bet pakankamai trumpą greičio pereinamaji vyksmą paleidimo metu.

Antrojo bandymo metu šešiafazis asinchroninis variklis buvo paleidžiamas, esant maitinimo įtampai $100 \mathrm{~V}$. Gauta paleidimo proceso greičio pereinamojo vyksmo kreivè pateikta 3.42 paveiksle. 


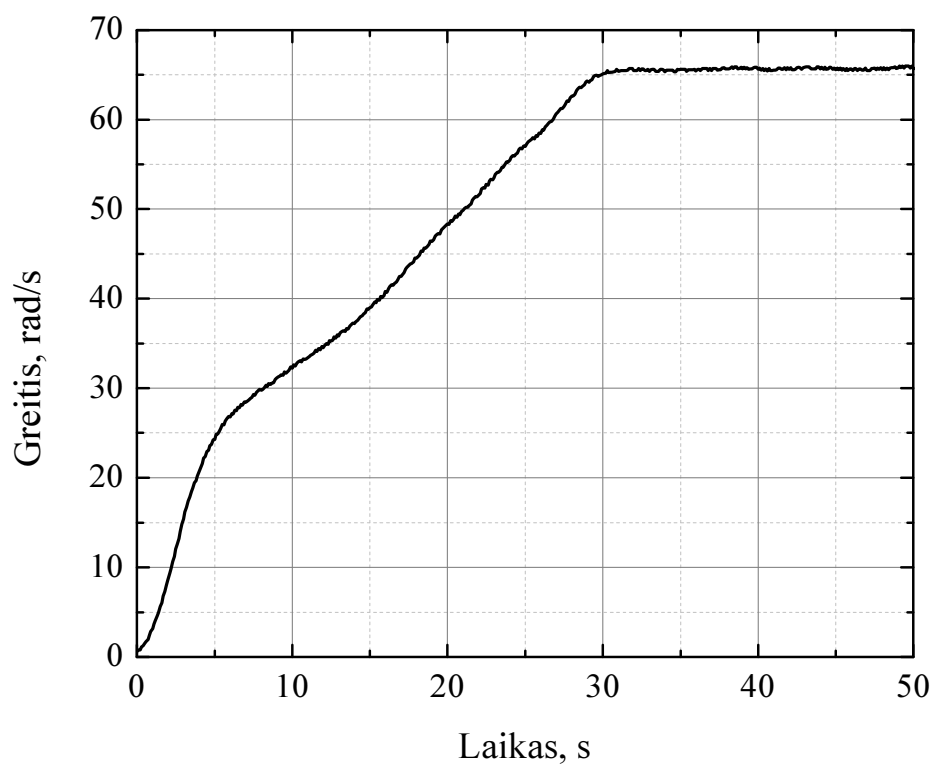

3.42 pav. Šešiafazio asinchroninio variklio paleidimo greičio pereinamasis vyksmas, kai maitinimo itampa lygi $100 \mathrm{~V}$

Fig. 3.42. Speed characteristic of six phase induction motor, at $100 \mathrm{~V}$ supply voltage

Iš 3.42 paveikslo matyti, kad paleidžiant šešiafazi asinchroninị varikli, kai jis maitinamas $100 \mathrm{~V}$ itampa, jo greitis nusistovi per 29 s rotoriui pasiekus 66 $\mathrm{rad} / \mathrm{s}$ greiti.

Lyginant greičio pereinamujų vyksmu kreives esant $75 \mathrm{~V}$ ir $100 \mathrm{~V}$ maitinimo itampoms matyti, kad $25 \mathrm{~V}$ padidinus maitinimo itampą pasiekiamas 9,4 karto didesnis rotoriaus nusistovejjęs greitis. Tačiau variklio paleidimo metu gauta greičio pereinamojo vyksmo trukmè išauga 6,7 karto.

Trečiojo bandymo metu šešiafazis asinchroninis variklis buvo paleidžiamas, esant maitinimo įtampos vertei lygiai $125 \mathrm{~V}$. Gauta paleidimo metu greičio pereinamojo vyksmo kreivè pateikta 3.43 paveiksle. Iš paveikslo matyti, kad šešiafazio asinchroninio variklio greitis variklio paleidimo metu nusistovi per $7,5 \mathrm{~s}$, kai jo rotorius pasiekia $74 \mathrm{rad} / \mathrm{s}$ greiti. Maitinimo itampos padidinimas 25 $\mathrm{V}$ padidina variklio rotoriaus greičio nusistovejusią vertę 1,1 karto. Paleidimo metu greičio pereinamasis vyksmas sutrumpejja 3.8 karto.

Ketvirtojo, penktojo, šeštojo ir septintojo bandymų metu šešiafazis asinchroninis variklis buvo paleidžiamas esant $150 \mathrm{~V}, 175 \mathrm{~V}, 200 \mathrm{~V}, 225 \mathrm{~V}$ 
maitinimo įtampoms. Gautos paleidimo proceso greičio pereinamujų vyksmų kreivès pateiktos 3.44 paveiksle. Pirmoji kreive vaizduoja greičio pereinamaji vyksmą, esant $150 \mathrm{~V}$, antroji, esant $175 \mathrm{~V}$, trečioji, esant $200 \mathrm{~V}$ ir ketvirtoji, esant $225 \mathrm{~V}$ maitinimo įtampoms.

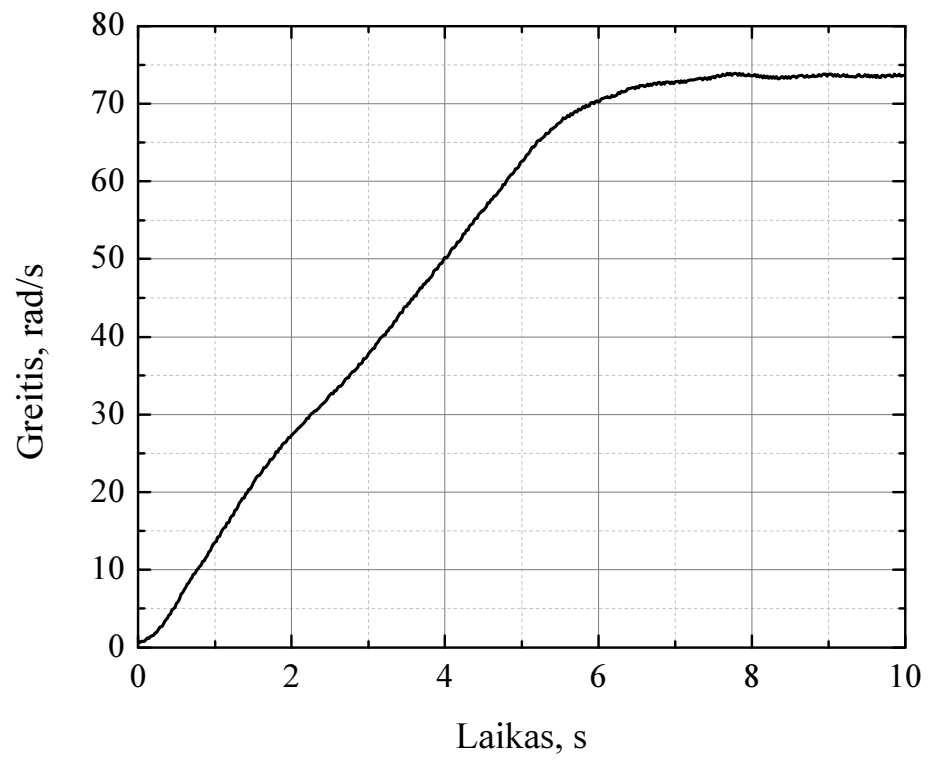

3.43 pav. Šešiafazio asinchroninio variklio paleidimo greičio pereinamasis vyksmas, kai maitinimo itampa lygi $125 \mathrm{~V}$

Fig. 3.43. Speed characteristic of six phase induction motor, at $125 \mathrm{~V}$ supply voltage

Iš 3.44 paveikslo matyti, kad šešiafazị asinchroninị variklį maitinant $150 \mathrm{~V}$ itampa, greičio paleidimo pereinamasis vyksmas trunka 3,8 s. Per ši laiko tarpą variklio rotorius pasiekia $75 \mathrm{rad} / \mathrm{s}$ greiti. Padidinus ịtampą iki $175 \mathrm{~V}$, greičio paleidimo procesas sutrumpeja $1,4 \mathrm{~s}$ ir rotoriaus greitis nusistovi po $2,4 \mathrm{~s}$. Rotoriaus greitis pasiekia $76 \mathrm{rad} / \mathrm{s}$. Esant maitinimo itampai lygiai $200 \mathrm{~V}$, rotoriaus nusistovèjęs greitis keičiasi nežymiai. Jo verte yra $78 \mathrm{rad} / \mathrm{s}$. Greičio pereinamasis procesas ir toliau akivaizdžiai trumpejja. Jis trunka 1,7 s. Paskutiniojo bandymo metu, kai variklis buvo maitinamas $225 \mathrm{~V}$ ịtampa, nustatyta, kad variklio rotoriaus greitis pasiekia nusistovejjusią $78 \mathrm{rad} / \mathrm{s}$ vertę ir pereinamasis vyksmas trunka $1,25 \mathrm{~s}$.

3.45 ir 3.46 paveiksluose pateiktos imitacinio ir eksperimentinio bandymų metu gautos šešiafazio asinchroninio variklio paleidimo momento ir greičio 
pereinamujų vyksmų kreivès, kai statoriaus apvijos maitinamos $200 \mathrm{~V}$ ịtampa. Śiuose paveiksluose pirmuoju numeriu yra pažymèta imitacinio bandymo kreive, antruoju numeriu - eksperimentinio bandymo.

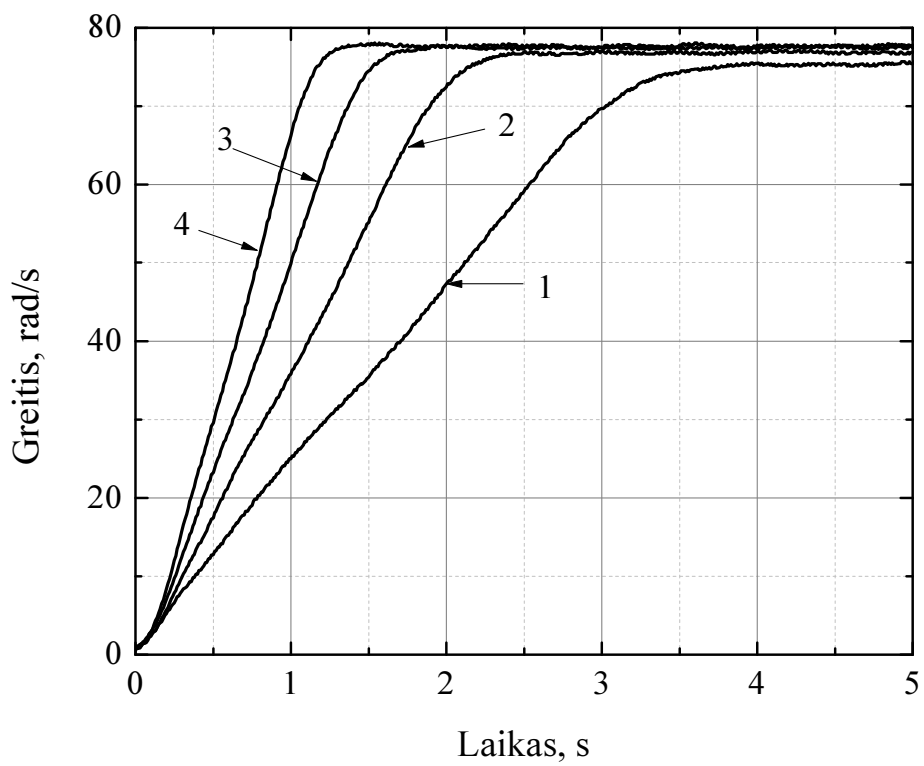

3.44 pav. Šešiafazio asinchroninio variklio paleidimo greičio pereinamasis vyksmas, kai maitinimo itampa lygi: $1-150 \mathrm{~V} ; 2-175 \mathrm{~V} ; 3-200 \mathrm{~V} ; 4-225 \mathrm{~V}$

Fig. 3.44. Speed characteristic of six phase induction motor. Supply voltage is: $1-150$ $\mathrm{V} ; 2-175 \mathrm{~V} ; 3-200 \mathrm{~V} ; 4-225 \mathrm{~V}$

Iš 3.45 paveikslo matyti, kad paleidžiant varikli imitacinio bandymo metu momentas nusistovi per $1,65 \mathrm{~s}$, o eksperimentinio bandymo metu per $1,7 \mathrm{~s}$. Didžiausias momentas, gautas iš imitacinio bandymo, yra $4,8 \mathrm{~N} \cdot \mathrm{m}$, o iš eksperimentinio $-5 \mathrm{~N} \cdot \mathrm{m}$. Iš 3.46 paveikslo matyti, kad tiek eksperimentinio tiek imitacinio bandymo nusistovejjusio greičio verte yra $78 \mathrm{rad} / \mathrm{s}$. Todèl galima teigti, kad sudarytas šešiafazio asinchroninio variklio imitacinis modelis, esant $200 \mathrm{~V}$ itampai, imituoja variklio paleidimo pereinamojo vyksmo trukmę 3 procentu paklaida, o didžiausiojo momento vertę 4 procentų paklaida. Tuo tarpu šešiafazio asinchroninio variklio nusistovejjusio greičio vertę imituoja artimą eksperimentiniai. 


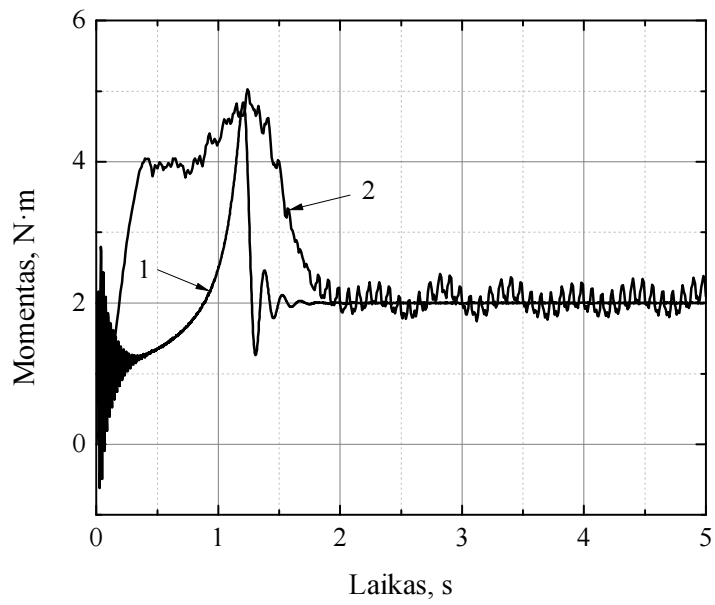

3.45 pav. Šešiafazio asinchroninio variklio paleidimo momento pereinamasis vyksmas, kai maitinimo itampa lygi $200 \mathrm{~V}$

Fig. 3.45. Torque characteristic of six phase induction motor, at $200 \mathrm{~V}$ supply voltage

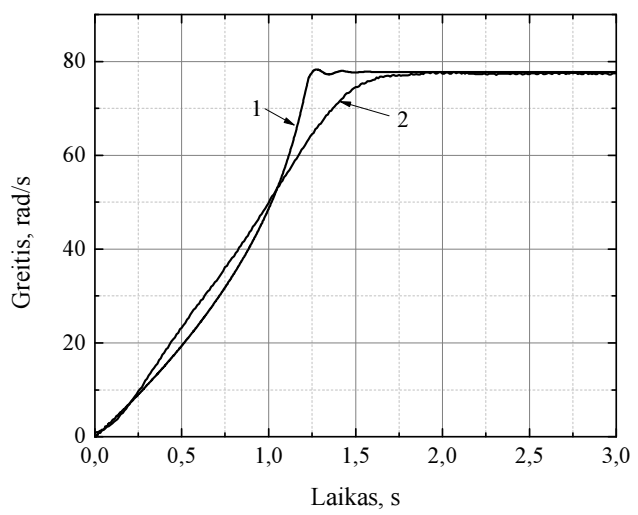

3.46 pav. Šešiafazio asinchroninio variklio paleidimo greičio pereinamasis vyksmas, kai maitinimo itampa lygi $200 \mathrm{~V}$

Fig. 3.46. Speed characteristic of six phase induction motor, at $200 \mathrm{~V}$ supply voltage 
3.47 ir 3.48 paveiksluose pateiktos imitacinio ir eksperimentinio bandymų gautos šešiafazio asinchroninio variklio paleidimo momento ir greičio pereinamujų vyksmų kreivès, kai statoriaus apvijos maitinamos $225 \mathrm{~V}$ ịtampa.

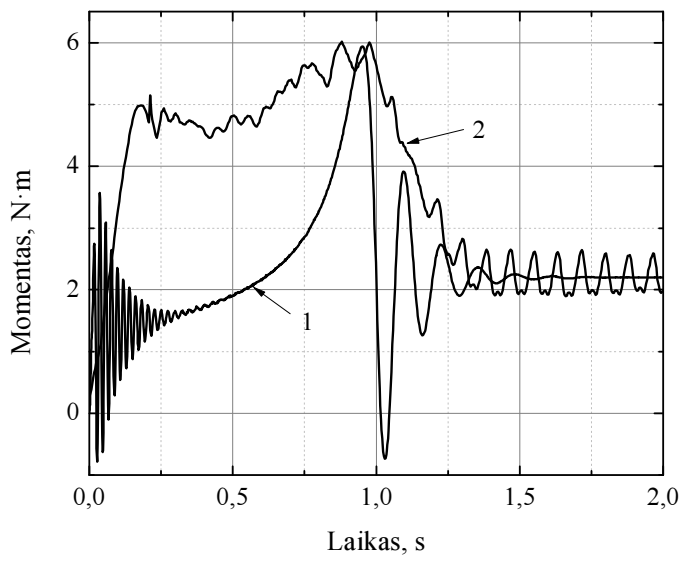

3.47 pav. Šešiafazio asinchroninio variklio paleidimo momento pereinamasis vyksmas, kai maitinimo itampa lygi $225 \mathrm{~V}$

Fig. 3.47. Torque characteristic of six phase induction motor, at $225 \mathrm{~V}$ supply voltage

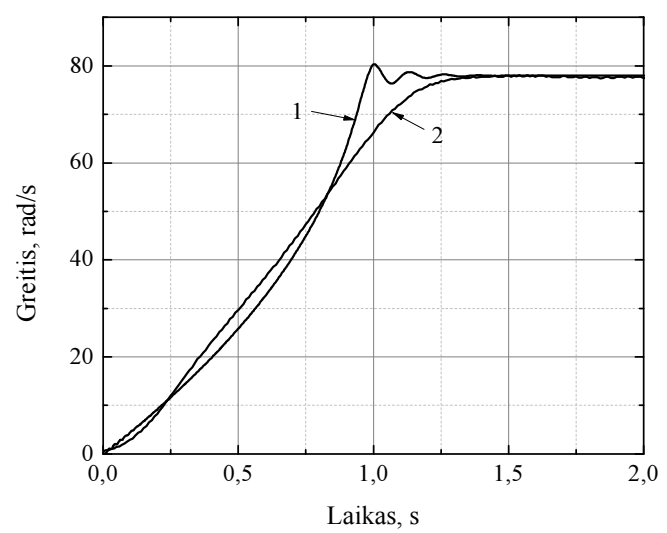

3.48 pav. Šešiafazio asinchroninio variklio paleidimo greičio pereinamasis vyksmas, kai maitinimo itampa lygi $225 \mathrm{~V}$

Fig. 3.48. Speed characteristic of six phase induction motor, at $225 \mathrm{~V}$ supply voltage 
Iš 3.47 paveikslo matyti, kad paleidžiant varikli imitacinio bandymo metu momentas nusistovi per $1,3 \mathrm{~s}$, o eksperimentinio bandymo metu per $1,25 \mathrm{~s}$. Didžiausia sukimo momento verte imitacinio ir eksperimentinio bandymų metu yra $6 \mathrm{~N} \cdot \mathrm{m}$. Iš 3.48 paveikslo matyti, kad tiek eksperimentinio tiek imitacinio bandymų metu pasiekiama nusistovejjusio greičio verte yra $78 \mathrm{rad} / \mathrm{s}$. Todèl galima teigti, kad sudarytas šešiafazio asinchroninio variklio imitacinis modelis, esant $225 \mathrm{~V}$ ịtampai, imituoja variklio paleidimo pereinamojo vyksmo trukmę 4 procentu paklaida, o maksimalią momento vertę imituoja artimą eksperimentiniai. Šešiafazio asinchroninio variklio nusistovejusio greičio vertę taip pat imituoja artimą eksperimentiniai. Tačiau abiem nagrinejjamais atvejais imitacinis pereinamasis vyksmas ne visiškai kartoja eksperimentinio vyksmo tarpinius rezultatus.

\subsection{Trečiojo skyriaus išvados}

Atlikus sudaryto pagal statoriaus ir rotoriaus srovių išraiškas Matlab ${ }^{\circledR}$ Simulink $^{\circledR}$ šešiafazio asinchroninio variklio modelio imitacinių ir pagaminto šešiafazio asinchroninio variklio eksperimentinių rezultatų analizę konstatuota, kad sukurtas modelis gali būti naudojamas šešiafazių asinchroninių variklių pereinamujų vyksmų tyrimui.

1. Šešiafazio variklio suminè magnetovara yra ekvivalentiška dviejų trifaziu variklių magnetovarai, kai statoriaus apvijos maitinamos simetriška šešiafaze itampa, kurios įtampų ir srovių fazès skiriasi 60 elektrinių laipsnių kampais, statoriaus grioveliuose kas 60 elektriniu laipsnių suklotos šešios fazinès apvijos ir visų fazių magnetovaros yra lygios.

2. Atlikus magnetovaros harmonikų spektro analizę nustatyta, kad sutelktosios dvisluoksnès sutrumpinto žingsnio šešiafazès apvijos magnetovaros pirmoji harmonika yra 22 procentais didesnè negu sutelktosios dvisluoksnès poliaus žingsnio šešiafazès apvijos.

3. Atlikus sukurto ir pagaminto sutelktosios dvisluoksnès sutrumpinto žingsnio apvijos šešiafazio asinchroninio variklio eksperimentinių ir imitacinių rezultatų tyrimą nustatyta, kad nusistovejjusios sukimo momento ir greičio eksperimentinès ir apskaičiuotos vertès skiriasi mažiau kaip $4 \%$.

4. Palyginus imitacinių ir eksperimentinių tyrimo rezultatus matyti, kad imitacinis pereinamojo proceso vyksmas pilnai neatkartoja eksperimentinio vyksmo tarpinių rezultatų. 



\section{Bendrosios išvados}

1. Pasiūlytu šešiafazio asinchroninio variklio Matlab $^{\circledR}$ Simulink $^{\circledR}$ modeliu pagal statoriaus ir rotoriaus srautų išraiškas galima tirti šešiafazio asinchroninio variklio pereinamuosius vyksmus paleidimo ir apkrovos metu. Šis variklio modelis yra tinkamas naudoti kuriant šešiafazių variklių valdymo sistemas. Naudojant šešiafazio asinchroninio variklio imitacinị modeli greitojo prototipo sistemose galima atlikti atskirų elementų sintezę ir analizę.

2. Sudarytų statoriaus sutelktosios dvisluoksnès sutrumpinto žingsnio šešiafazès apvijos ir sutelktosios dvisluoksnès poliaus žingsnio šešiafazès apvijos analizè rodo, kad geresnèmis savybėmis pasižymi sutelktoji dvisluoksnė sutrumpinto žingsnio apvija. Ši apvija suklota mūsų pagaminto eksperimentinio variklio statoriuje. Atlikus eksperimentinius matavimus nustatyta, kad eksperimentinio šešiafazio aštuonių polių asinchroninio variklio slydimas yra 0,01 ir tuščiosios veikos greitis $78 \mathrm{rad} / \mathrm{s}$ yra artimas sukamojo magnetinio lauko sinchroniniam greičiui $78,5 \mathrm{rad} / \mathrm{s}$.

3. Eksperimento metu gautos dinaminès šešiafazio asinchroninio variklio paleidimo charakteristikos maitinant ji skirtinga itampa. Atlikus 
eksperimentinių rezultatų lyginamąją analizę su imitacijos rezultatais nustatyta, kad sudarytas šešiafazio asinchroninio variklio modelis imituoja: variklio paleidimo pereinamojo vyksmo trukmę $4 \%$ maksimalia paklaida, didžiausio momento vertę pereinamojo vyksmo metu - $4 \%$ maksimalia paklaida, nusistovejjusio greičio vertę - artimą eksperimentiniai. Taip pat nustatyta, kad dèl modelio sudarymo supaprastinimo prielaidu imitacijos rezultatai ne visiškai kartoja eksperimentinio bandymo tarpinius rezultatus.

4. Imitaciniais tyrimais gauta, kad didinant šešiafazio asinchroninio variklio maitinimo įtampą ir ji apkraunant, didžiausiasis momentas padidejja, tačiau momento pereinamojo vyksmo trukmè sumažèja. Imitaciniais ir eksperimentiniais tyrimais parodyta, kad paleidžiant variklį gaunamas toks pats reiškinys: didžiausias momentas didèja, tačiau pereinamojo vyksmo trukmè mažèja. 


\section{Literatūros sąrašas}

Abbas, M. A.; Christen, R.; Jahns, T. M. 1984. Six-phase Voltage Source Inverter Driven Induction Motor, in IEEE Transactions Industrial Applications. 5(20):12511259.

Abolhassani, M. T. 2005. A Novel Multiphase Fault Tolerant High Torque Density Permanent Magnet Motor Drive for Traction Applications, in Proceedings IEEE IEMDC, San Antonio, TX: 728-734.

Andrese, E.; Bieniek, K. 1981. 6-phase Induction Motors for Current-Source Inverter Drives, in Conference Recorded IEEE IAS Annual Meeting, Philadelphia: 607-618.

Apsley, J. M.; Gonzalez-Villasenor, A.; Barnes, M.; Smith, A. C.; Williamson, S.; Schuddebeurs, J. D.; Norman, P. J.; Booth, C. D.; Burt, G. M. 2009. Propulsion Drive Models for Full Electric Marine Propulsion Systems, in IEEE Transactions on Industry Applications 2(45): 676-694.

Apsley, J. M.; Williamson, S. 2005. Analysis of multi-phase induction machines with winding fault, in Proceedings IEEE IEMDC, San Antonio, TX: 249-255.

Ahmad, M. 2010. High Performance AC Drives. Modeling Analysis and Control. Springer, London, UK. ISBN 978-3-642-13149-3, 290 p.

Blaschke, F. 1972. Principal of field orientation applied to the new transvector closed loop control system for rotating field machines, in Siemens Review, vol. 39. 217-220.

Boldea, S.; Nasar, A. 2005. Electric drives. Taylor \& Francis Group CRC. 522 p. 
Bojoi, R.; Farina, F.; Lazzari, M.; Profumo, F.; Tenconi, A. 2003. Analysis of the assymmetrical operation of dual three-phase induction machines, in Proceedings IEEE IEMDC: 429-435.

Bojoi, R.; Griva, G.; Profumo, F. 2006. Field oriented control of dual three-phase induction motor drives using a Luenberger flux observer, in Conference Recorded IEEE IAS Annual Meeting, Tampa:1253-1260.

Bojoi, R.; Lazzari, M.; Profumo, F.; Tenconi, A. 2002. Digital field oriented control for dual three-phase induction motor drives, in Conference Recorded IEEE IAS Annual Meeting, Pittsburg: 818-825.

Bojoi, R.; Levi, E.; Farina, F.; Tenconi, A.; Profumo, F. 2006. Dual three-phase induction motor drive with digital current control in the stationary reference frame, Proceedings IEEE Power Applications 1(153): 129-139.

Bojoi, R.; Profumo, F.; Tenconi, A. 2003. Digital synchronous frame current regulation for dual three-phase induction motor drives, in Proceedings IEEE PESC, Acapulco, Mexico: 1475-1480.

Bojoi, R.; Tenconi, A.; Griva, G.; Profumo, F. 2005. Vector control of dual three-phase induction motor drives using two current sensors, in Conference Recorded IEEE IAS Annual Meeting, Hong Kong: 1805-1812.

Bolton W. 2003. Mechatronics. Electronic control systems in mechanical and electrical engineering (3rd edition). England. 567 p.

Bose, B. K. 2002. Modern power electronics and AC drives. New Jersy, Prentice Hall. $738 \mathrm{p}$.

Bose, B. 2006. Power Electronics and Motor Drives. Elsevier, San Diego, USA. ISBN 978-0-12-088405-6, $851 \mathrm{p}$.

Bugenis, S. J.; Vanagas, J.; Gečys, S. 2008. Optimal Phase Number of Induction Motor with the Integrated Frequency Converter. Electronics and Electrical Engineering, Kaunas, Lithuania. 67-70.

Bukšnaitis, J. J. 2007. Kintamosios srovès trifazių elektros mašinu apviju elektromagnetinis efektyvumas. Kaunas. 196 p.

Camillis, L. D.; Matuonto, M.; Monti, A.; Vignati, A. 2001. Optimizing current control perfomance in double winding asynchronous motors in large power inverter drives, IEEE Transactions Power Electronics 5(16): 676-685.

Casadei, D.; Mengoni, M.; Serra, G.; Tani, A.; Zarri, L. 2008. Optimal Fault-Tolerant Control Strategy for Multi-Phase Motor Drives Under an Open Circuit Phase Fault Condition. Proceedings of the 2008 International Conference on Electrical Machines: $1-6$.

Chiasson, J. 2005. Modeling and high performance control of electrical machines. IEEE Press Wiley Interscience, Hoboken, USA. ISBN 0-471-68449-X. 736 p.

Corzine, K. A.; Sudhoff, S. D.; Lewis, E. A.; Schmucker, D. H.; Youngs, R. A.; Hegner, H. J. 1998. Use of Multi-level converters in Ship Propulsion Drives, in Proceedings All Electric Ship Conference, London: 155-163. 
Dasika, J. D.; Qin, J.; Saeedifard, M.; Pekarek, S. D. 2012. Predictive Current Control of a Six-Phase Assymmetrical Drive System Based on Parrallel-Connected Back-to-Back Converters, in Energy Conversion Congress and Exposition: 137-141.

Drozdowski, P. 2011. Multiphase Cage Induction Motors for Controlled Drives. Zeszyty Problemowe - Maszyny Elektryczne: 7-12.

Duran, M. J.; Salas, F.; Arahal, M. R. 2008. Bifuration Analysis of Five-Phase Induction Motor Drives With Third Harmonic Injection, in IEEE Transactions on Industrial Electronics 5(55): 2006-2014.

Freescale semicondoctors. [Interaktyvus] 2013. [Žiūrèta: 2013-03-09]. $<$ http://www.freescale.com/files/32bit/doc/app note/AN3000.pdf $>$.

Fu, J. R.; Lipo, T. A. 1994. Disturbance-free operation of a multiphase current-regulated motor drive with opened phase, in IEEE Transactions Industry Applications 5(30): $1267-1274$.

Gečys, S.; Kalvaitis, A.; Smolskas, P. 2010. Elektros mašinos. Kaunas: Technologija. 209 p.

Golubev, A. N., Ignatenko, V. 2001. Anomalous operation of multiphase asynchronous electric drive, Russian Electronic Engineering. 10(72): 22-28.

Gopakumar, K.; Sathiakumar, S; Biswas, S. K.; Vithayathil, J. 1984. Modified Current Source Inverter Fed Induction Motor Drive with Reduced Torque Pulsation, Proceedings IEE 4(131): 159-164.

Gregor, R.; Barrero, Duran, M. J.; Arahal, M. R.; Toral, S. 2008. Model Based Predictive Current Control of Asynchronous Six-phase Motor Drive [Žiūrèta: 2012-0411]. < http://www.icrepq.com/icrepq-08/230-gregor.pdf $>$.

Gregor, R.; Barrero, F.; Toral, S.; Duran, M. J. 2008. Realization of an Asynchronous Six-Phase Induction Motor Drive Test-Rig, International Conference on Renewable Energy and Power Quality: 1-5.

Grigore-Muler, O.; Barbelian M. 2010. The simulation of a multi-phase induction motor drive, 12th International Conference on Optimization of Electric and Electronic Equipment, OPTIM: 297-306.

Gritter, D.; Kalsi, S. S.; Henderson, N. Variable Speed Electric Drive Options for Electric Ships, in Proceedings IEEE ESTS, Philadelphia: 374-354.

Hasse, K. 1969. Zur dynamik drehzahlgeregelter antriebe mit stromrichtergespeisten asynchron-kurzschlußläufermaschinen. Darmstadt, tech Hochsch. 1-10.

Hua, L.; Yunping, Z.; Bi, H. 2006. The vector control strategies for multi-phase synchronous motor drive systems, in Proceedings IEEE ISIE, Montreal, Canada: 22052210 .

Hou, L.; Su, Y.; Chen, L. 2003. DSP-based indirect rotor flux oriented control for multiphase induction machines, in Proceedings IEEE IEMDC, Madison:976-980.

Iqbal, A.; Ahmed, S. M.; Khan, M. A.; Khan, M. R.; Abu-Rub, H. 2010. Modeling, Simulation and Implementation of a Five-Phase Induction Motor Drive System, in Join International Conference on Power Electronic, Drives and Energy Systems: 1-6. 
Iqbal, A.; Moinuddin, S.; Khan, M. R.; Ahmed S. M.; Abu-Rub, H. 2010. A Novel Three-Phase Transformation Using a Special Transformer Connection, in IEEE Transactions on Power Delivery 3(25): 1637-1644.

Jacobina, C. B.; Freitas, I. S.; Oliveira, T. M.; da Silva, E. R. C.; Lima, A. M. N. 2004. Fault tolerant control of five-phase AC motor drive, in Proceedings IEEE PESC, Aachen, Germany: 3486-3492.

Jacobina, C. B.; Miranda, R. S.; Correa, M. B. D. R., Lima A. M. N. 2004. Disturbancefree operation of a six-phase AC motor drive system, in Proceedings IEEE PESC, Aachen, Germany: 925-931.

Jacobina, C. B.; Miranda, R. S.; Lima A. M. N. 2005. Reconfigurable fault tolerant dualwinding AC motor drive System, in Proceedings IEEE PESC, Recife, Brazil: 15741579 .

Jahns, T. M. 1980. Improved reliability in solid-state AC drives by means of multiple independent phase-drive units, in IEEE Transaction Industry Applications 3(16): 321331.

Janickas, R. 2013. Mechatroniniu pavaru parametru identifikavimas realiuoju laiku. Daktaro disertacija. Vilniaus Gedimino technikos universitetas. $106 \mathrm{p}$.

Jian Yu Finch, J. W.2001. An alternative way to the scalar control of induction drives, in Electrical Machines and Systems the Fifth International Conference vol.2. 683-686.

Jones, M.; Vukosavic, S. N.; Levi, E.; Iqbal, A. 2005. A Six-Phase Series-Connected Two-Motor Drive With Decoupled Dynamic Control, in IEEE Transactions on Industry Applications 4(41): 1056-1066.

Juraitis, S. 2012. Dvimasès elektromechaninès sistemos pereinamujų vyksmu tyrimas. Daktaro disertacija. Vilniaus Gedimino technikos universitetas. 122 p.

Joliet technologies [Interaktyvus] 2013 [Žiūrèta: 2013-01-08] $<$ http://www.joliettech.com/what is a variable frequency drive.htm>.

Kadaba, A.; Suo, S.; Sizov, G. Y.; Yeh, C. C.; Sayed-Ahmed, A.; Demerdash, N. A. O.; Fellow, L. 2011. Design and Modeling of a Reversible 3-Phase to 6-Phase Induction Motor for Improved Survivability, in Power and Energy Society General Meeting: 1-5.

Kats, Y. 1997. Adjustable-Speed Drives With Multiphase Motors, in IEEE Conference: $1-3$.

Kazmierkowski, M. P.; Krishnan, R.; Blaabjerg, F. 2002. Control in power Electronics in Selected Problems. Elsevier Science. USA. 509 p.

Kianinezhad, R.; Nahid, B.; Baghli, J.; Betin, F.; Capolino, G. A. 2006. Aspects of current regulation in indirect field oriented control of dual three phase induction machines, in Proceedings IEEE ICIT, Mumbai, India: 933-938.

Kianinezhad, R.; Nahid, B.; Betin, F.; Capolino, G. A. 2004. A new field orientation control of dual three phase induction machine, in Proceedings IEEE ICIT, Hammamet, Tunisia: 187-192. 
Kianinezhad, R.; Nahid-Mobarakeh, B.; Betin, F.; Capolino, G. A. 2005. Sensorless field-oriented control for six-phase induction machines, in Conference Recorded IEEE IAS Annual Meeting, Hong Kong: 999-1006.

Krause, P.; Wasynczuk, O.and Sudhoff, S. 2002. Analysis of Electric Machinery and Drive systems, $2^{\text {nd }}$ ed., New York: Willey IEEE. 619 p.

Kriaučiūnas, J. 2013. Bejutiklių asinchroninių dažninių pavarų tyrimas. Daktaro disertacija. Vilniaus Gedimino technikos universitetas. 94 p.

Leonhard, W. 2001. Control of electric drives, $3^{\text {rd }}$ edition. Springer. 440 p.

Levi, E. 2008. Multiphase Electric Machines for Variable-Speed Applications, in IEEE Transactions on Industrial Electronics: 1893-1909.

Levi, E.; Bojoi, R.; Profumo, F.; Toliyat, H. A.; Williamson, S. 2007. Multiphase induction motor drives - a technology status review, in IET Electric Power Applications 1(4): 489-516.

Lipinskis, T. Daugiafazių dažnio keitiklių įtampos formavimo metodų analizè, Mokslas - Lietuvos ateitis = Science - future of Lithuania: elektronika ir elektrotechnika = Electronics and electrical engineering: 119-123.

Lipinskis, T.; Baškys, A.; Rutkauskas, A. 2013. Six-phase voltage forming method using the largest magnitude space vectors. Electronics and Electrical Engineering, Kaunas, Lithuania. 99-102.

Lipo, T. A. 1980. A d-q model for six-phase induction machine, in Proceedings on International Conference on Electric machines:860-867.

Locment, F.; Semail, E.; Kestelyn, X.; Bouscayrol, A. 2006. Control of a seven-phase axial flux machine designed for fault operation, in Proceedings IEEE IECON, Paris, France: 1101-1106.

Lu, S.; Corzine, K. 2005. Multilevel Multi-Phase Propulsion Drives, in IEEE Electric Ship Technologies Symposium: 363-370.

Mantero, S.; Monti, A.; Spreafico, S. 2000. DC-bus Voltage Control for Double Star Asynchronous Fed Drive Under Fault Conditions, in Proceedings IEEE PESC, Galway, Ireland: 533-538.

Mantero, S.; Paola, E. D.; Marina, G. 1999. An Optimised Control Strategy for Double Star Motors Configuration in Redundancy Operation Mode, in Proceedings Eur. Power Electronics Applications Conference (EPE), Lausanne, Switzerland.

Marino, R.; Tomei, P. \& Verrelli, C. 2010. Induction Motor Control Design. Springer. London, UK. ISBN 978-1-84996-283-4. 363 p.

McSharry, J. P.; Hamer, P. S.; Morrison, D.; Nessa, J.; Rigsby, J. G. 1998. Design, fabrication, back-to-back test of 14200-HP two-pole cylindrical-rotor synchronous motor for ASD application, in IEEE Transactions Industry Applications 3(34): 526-533.

Merabtene, M.; Benkhoris, M. F.; LeDoeuff, R. 2003. A unified model to control the DSSM PWM inverter set under balanced and unbalanced functioning, in Proceedings Eur. Power Electronics Applications Conference (EPE), Toulouse, France. 
Miranda, R. S.; Jacobina, C. B.; Lima, A. M. N. 2009. Modeling and Analysis of SixPhase Induction Machine Under Fault Condition. Power Electronics Conference COBEP'09. Brazilia. 824-829.

Monti, A.; Morando, A. P.; Resta, L.; Riva, M. 1995. Comparing Two-Level GTOInverter Feeding a Double Star Asynchronous Motor with a Three level GTO-Inverter feeding Single Star Asynchronous Motor, in Proceedings EPE, Seville, Spain: 2.4192.425 .

Nabi, H. P.; Dadashi, P.; Shoulaie, A. 2011. A Novel Structure for Vector Control of Symmetrical Six-Phase Induction Machines with Three Current Sensors, in ETASR Engineering, Technology and Applied Science Research 1(2): 23-29.

Nanoty, A.; Chudasama, A. R. 2012. Control of Designed Developed Six Phase Induction Motor. Electromagnetics and Applications: 77-84.

Nanoty, A.; Chudasama, A. R. 2013. Design, Development of Six Phase Squirrel Cage Induction Motor and its Comparative Analysis with Equivalent Three Phase Squirrel Cage Induction Motor Usind Circle Diagram. Emerging Technology and Advanced Engineering: 731-737.

Oleschuk, V.; Grandi, G.; Sanjeevikumar, P. 2011. Simulation of Processes in Dual Three-Phase System on the Base of Four Inverters with Synchronized Modulation. Advances in Power Electronics: 1-9.

Ong, C-M. 1998. Dynamic simulation of electric machinery using Matlab/Simulink. Prentice Hall. New Jersey, USA. ISBN 0-13-723785-5. 626 p.

Parsa, L.; Toliyat, H. A. 2004. Fault-tolerant control five-phase permanent magnet motor drives, in Conference Recorded IEEE IAS Annual Meeting, Seattle, WA: 1048-1054.

Pavithran, K. N.; Parimelagan, R.; Krishnamurthy, M. R. 1988. Studies on Inverter-Fed Five-Phase Induction Motor Drive, in IEEE Transactions Power Electronics 2(3): 224235.

Petrovas, A. 2007. Trifaziu asinchroniniu varikliu dinaminiai modeliai. Daktaro disertacija. Vilniaus Gedimino technikos universitetas. 93 p.

Rashid, M. H. 2001. Power electronics handbook, in Academic Press, Anglija. 892 p.

Rata, I.; Todos, P.; Nuca, I. 2007. A review of the multiphase electric machines, 6th International Conference on Electromechanical and Power Systems: 154-159.

Reljić, D. D.; Ostojić, D. B.; Vasić, V. V. 2006. Simple speed sensorless control of induction motor drive, in Sixth international symposium Nikola Tesla. 1-4.

Renukadevi, G.; Rajambal, K. 2011. Generalized Model of Multi-Phase Induction Motor Drive Using Matlab/Simulink, in Innovative Smart Grid Technologies: 114-119.

Rinkevičienè R., Petrovas A. 2007. Mechatroninių sistemų modeliavimas. Mokomoji knyga. Vilnius. 156 p.

Rinkevičienè, R.; Petrovas, A. 2005. Dynamic models of linear induction drives. In Information Technology and Control, Nr. 1(34). 37-41.

Robyns, B.; Francois; B., Degobert, P.; Hautier, J. P. 2012. Vector control of induction machines. ISBN:978-0-85729-900-0. 222 p. 
Smith, A. C.; Williamson, S.; Hodge, C. G. 2003. High Torque Dense Naval Propulsion motors, in Proceedings IEEE IEMDC, Madison: 1421-1427.

Simond, J. J.; Sapin, A.; Xuan, T.; Wetter, R.; Burmeister, P. 2005. 12-pulse LCI synchronous drive for a 20 Mwncompressor: Modelling, simulation and measurements, in Conference Recorded IEEE IAS Annual Meeting, Hong Kong: 2302-2308.

Singh, G. K.; Nam, K.; Lim, S. K. 2005. A simple indirect field-oriented control scheme for multiphase induction machine, in IEEE Transactions Industry Electronics 4(52): 1177-1184.

Singh, G. K.; Pant. 2000. Analysis of multiphase induction machine under fault condition in a phase-redundant AC drive systems, EMP Systems 6(28): 577-590.

Singh, G. K.; Pant, V.; Singh, Y. P. 2003. Voltage source inverter driven multi-phase induction machine, Computers and Electrical Engineering 29: 813-834.

Steiner, M.; Deplazes, R.; Stemmler, H. 2000. A New Transformerless Topology for AC-Fed Traction Vehicles Using Multi-Star Induction Motors, in EPE 3/4(10): 45-53.

Sul, S-K. 2011. Control of Electric Machine Drive Systems. IEEE Press, Wiley Interscience, Hoboken, USA. ISBN 978-0-470-87655-8. 339 p.

Sudhoff, S. D.; Alt, J. T.; Hegner, N. J.; Robey, H. N. 1997. Control of a 15-phase induction motor drive system, in Proceedings Naval Symposium Electrical Machines, Newport: 69-75.

Trzynadlowski, M.; Andrzej, P. 2001. Control of induction motors. Academic press. 228 p.

Venter, P; Jimoh, A. A. 2012. Realization of a 3 and 6 Phase Induction Machine, in International Conference on Electrical Machines: 447-453.

Vukosavic, S. N.; Jones, M.; Levi, E.; Varga, J. 2005. Rotor flux oriented control of a symmetrical six-phase induction machine, Electronic Power Systems 75(2/3): 142-152.

Wach, P. 2011. Dynamics and Control of Electric Drives. Springer. Berlin, Germany. ISBN 978-3-642-20221-6. 476 p.

Wang, H.; Zhao, R.; Cheng, F.; Yang, H. 2011. Six-Phase Induction Machines Driven By the Matrix Converter, in International Conference on Electrical Machines and Systems: 1-5.

Weichao, L.; Shiguang, H. A. G.; Chi, S. 2008. Rapid Control Prototyping of FifteenPhase Induction Motor Drives Based on dSPACE, International Conference on Electrical Machines and Systems: 1604-1607.

Williamson, S.; Smith, S. 2003. Pulsating Torque and Losses in Multiphase Induction Machines, in IEEE Transactions on Industry Applications 4(39): 986-993.

Williamson, S.; Smith, S. 2004. Fault Tolerance in Multiphase Propulsion Motors, in Marine Engineering Technologies: 3-7.

Zdenek, D. 1986. 25 MW High-Speed Electric Drive With Thyristor Speed Control, Heavy Industry 4: 5-9. 
Zheng, L.; Fletcher, J. E.; Williams, B. W. 2006. Current Optimisation for a Multi-phase Machine Under an Open-circuit Phase Fault Condition, in Proceedings IEE International Conference PEMD, Dublin, Ireland: 414-419. 


\section{Autoriaus mokslinių publikacijų disertacijos tema sąrašas}

\section{Straipsniai recenzuojamuose mokslo žurnaluose}

Kundrotas, B.; Lisauskas, S.; Rinkevičienè, R. 2011. Model of multiphase induction motor. Electronics and electrical engineering. No. 5(111): 111-114. Kaunas: Technologija. ISSN 13921215 (Thomson Reuters Web of Science).

Kundrotas, B. 2012. Daugiafazių variklių naudojimo sritys ir perspektyvos. Mokslas - Lietuvos ateitis $=$ Science - future of Lithuania: elektronika ir elektrotechnika = electronics and electrical engineering. T. 4, Nr. 1: 67-70. Vilnius: Technika. ISSN 2029-2341.

Kundrotas, B. 2013. Sutelktosios dvisluoksnès šešiafazės apvijos sudarymas. Mokslas - Lietuvos ateitis $=$ Science - future of Lithuania: elektronika ir elektrotechnika = electronics and electrical engineering. T. 5, Nr. 2: 160-163. Vilnius: Technika. ISSN 2029-2341.

Rinkevičienè, R.; Kundrotas, B; Lisauskas, S. 2013. Model of controled six phase induction motor. World Academy of Science, Engineering and Technology. Vol. 7, Nr. 1. Zurich. 217-221. ISSN 2010-376X.

Kundrotas, B.; Petrovas, A.; Rinkevičienè, R.; Smilgevičius, A. 2014. Research of Six-Phase Induction Motor Windings. Electronics and electrical engineering. No. 1(20): 15-18. Kaunas: Technologija. ISSN 1392-1215 (Thomson Reuters Web of Science). 


\section{Kituose leidiniuose}

Kundrotas, B.; Rinkevičienè, R.; Lisauskas, S. 2011. Control of six-phase induction drive. In 7th International conference on mechatronic systems and materials MSM 2011. Kaunas: Technologija. 209-210. ISSN 1822-8283.

Lisauskas, S.; Kundrotas, B.; Rinkevičienè, R.; Smilgevičius, A. 2011. Investigation into six-phase induction drive dynamic characteristics. In Proceedings of the 6th International Conference on Electrical and Control Technologies ECT-2011. Kaunas: Technologija. 218-221. ISSN 18225934.

Rinkevičienè, R.; Kundrotas, B.; Tolvaišienè, S. 2013. Model of six-phase induction motor. In 9th International conference on mechatronic systems and materials MSM 2013. Vilnius: Technika. 204-205. ISSN 1822-8283.

Kundrotas, B.; Rinkevičienè, R. 2013. Forming of six-phase double layer induction motor windings. In Proceedings of Doctoral School of Energy and Geotechnology II. Pärnu, Estonia. 9396. ISBN 978-9985-69-054-3. 


\section{Summary in English}

\section{Introduction}

\section{Formulation of the problem}

Six phase motors has many advantages over conventional three phase motors such as increased torque per ampere for the same volume of machine, reduced stator copper losses, reduced rotor harmonic currents, high power capability by dividing the required power between multiple phases, reduced torque pulsations and higher reliability. In particular, unlike in a three phase motor, the loss of stator phase does not prevent the machine from starting and running.

The six phase motors are more perspective compared with three phase motors in local systems where the one type of energy is converted in other one. It happens at nuclear power-stations, nuclear submarines, spacecrafts and others.

There are wide range of six phase motor speed control methods, because their are basically the same as for three phase motors.

The mathematical models are used to develop six phase motor dynamic characteristics. Usually the equations are solved in matrix form. The simulation software such as Matlab $^{\mathbb{R}}$ Simulink $^{\mathbb{R}}$ is more superior. Simulation models can be used in rapid prototyping and allows to verify system operation in real-time when part of examined system is changed by its computer model.

The type of stator winding has the substantial contribution to main machine characteristics. There for it is very important to investigate different types of six phase motor stator windings. 


\section{Topicality of the thesis}

The perfomed work demonstrates that six phase induction motor Matlab ${ }^{\circledR}$ Simulink $^{\mathbb{R}}$ model according to stator and rotor currents or to stator and rotor flux for six phase induction motor starting transients with different supply voltage and load can be used. This model can be applied for controlled induction drives development. Six phase induction motor Matlab $^{\mathbb{R}}$ Simulink $^{\mathbb{R}}$ model can be used in rapid prototyping to verify system operation.

\section{The object of research}

The six phase induction motor and their transients when different supply voltage and load are used.

\section{The aim of thesis}

To design six phase induction motor with concentrated double layer short pitch coil stator winding, to develop simulation model and to investigate transients of torque and speed.

\section{The tasks of the thesis}

The following tasks have to be solved to achieve the aim of the work:

1. Design concentrated double layer short pitch coil six phase winding and concentrated double layer full pitch coil six phase winding and to compare their efficiency.

2. Develop six phase induction motor computer model according to stator and rotor current differential equations and six phase asynchronous motor computer model according to stator and rotor flux differential equations.

3. Develop scalar controlled six phase induction drive simulation model and investigate transients of torque and speed.

4. Design and construct six phase induction motor test stand and verify adequacy of simulation results.

\section{The research methods}

Research includes analytical, digital, experimental investigation methods as well as object-oriented computer models and simulation. Simulation models are developed in Matlab $^{\mathbb{R}}$ Simulink $^{\mathbb{R}}$ software. Experimental studies are carried out with specialized test bench at Automation department laboratory of Vilnius Gediminas technical university.

\section{Scientific novelty}

The following research results were obtained, that are relevant in the area of electrical engineering and electronics:

1. New concentrated double layer short pitch coil six phase winding and new concentrated double layer full pitch coil six phase winding are formed. Their efficiency are compared and greater efficiency concentrated double layer short pitch coil winding practically tested. 
2. Developed new six phase asynchronous motor computer models according to stator and rotor current and flux equations, which can be used in rapid prototyping.

3. Developed new scalar controlled six phase asynchronous motor drive for transients investigation.

\section{Practical significance of the obtained results}

The investigation methodology and obtained results can be used to design frequency controlled six phase induction motor drives. Elaborated computer models can be easily improved and used to solve various engineering problems. Developed and tested by simulations systems can be used in real systems. The topicality of work is proved by the high technology development program project. During the implementation of it important results of the dissertation were obtained.

\section{Defended statments}

1. Formed concentrated double layer short pitch coil six phase winding has the first harmonic greater by $22 \%$ than concentrated double layer full pitch coil six phase winding.

2. Developed Matlab $^{\mathbb{R}}$ Simulink $^{\mathbb{R}}$ six phase induction motor model for dynamic characteristic investigation at different supply voltage, frequency and load cases can be used.

3. Elaborated and experimentally investigated six phase induction motor with concentrated double layer short pitch coil winding in stator shows simulation and experimental torque and speed transients values disjunction less than $4 \%$ in steady state.

\section{Approval of the dissertation}

Dissertation topic is printed in five scientific articles, two - in scientific journal included in the Thomson ISI (Web of Science) list (Kundrotas, et. al., 2011; Kundrotas, et. al., 2014), two - in national scientific journal included in the IndexCopernicus list (Kundrotas, 2012; Kundrotas, 2013) and one - in international scientific journal included in the Scopus list (Rinkevičienè, Kundrotas, et. al., 2013).

Dissertation research results have been published in four international scientific conferences.

\section{The structure of the dissertation}

The dissertation is written in Lithuanian. The dissertation layout consists of three main chapters, list of references and list of author's publications on the subject of dissertation. The work covers 118 pages, 99 figures, 3 tables, 43 numbered formulas and 104 bibliographic sources. In the first chapter mathematical models and control methods of six phase induction motors are reviewed. In the second chapter the development methodology and tools of six phase induction motors computer models are presented. Simulation and experimental results of six phase induction motor drive are presented in the third chapter. 


\section{Review of six phase induction motors and control methods}

Six phase motors are the focus of research recently due to their inherent advantages compared to three phase motors. Some of them: improved reliability as the machine continues running with one of its many phases open or short-circuited and there is not much performance degradation, reduced iron loss leading to improved overall performance, lower current per phase without increase in per phase voltage, increased torque per rms ampere for the same machine volume.

Six phase motors have been proposed for different applications: electric vehicles, nuclear power plants for its circulation pumps, ships, and spacecrafts.

In order to develop the six phase induction motor model, the following assumptions are made: the air gap is uniform and the windings are sinusoidally distributed around the air gap; magnetic saturation and core losses are neglected. As for three phase induction motor, $d-q$ rotating reference frame is used.

The six phase induction motor can be modeled with the following voltage equations in synchronous reference frame:

$$
\begin{aligned}
& u_{q s 1}=R_{s} i_{q s 1}+s \Psi_{q s 1}+\omega_{e} \Psi_{d s 1}, \\
& u_{d s 1}=R_{s} i_{d s 1}+s \Psi_{d s 1}-\omega_{e} \Psi_{q s 1}, \\
& u_{q s 2}=R_{s} i_{q s 2}+s \Psi_{q s 2}+\omega_{e} \Psi_{d s 2}, \\
& u_{d s 2}=R_{s} i_{d s 2}+s \Psi_{d s 2}-\omega_{e} \Psi_{q s 2}, \\
& u_{q r}=R_{r} i_{q r}+s \Psi_{q r}+\left(\omega_{e}-\omega_{r}\right) \Psi_{d r}, \\
& u_{d r}=R_{r} i_{d r}+s \Psi_{d r}-\left(\omega_{e}-\omega_{r}\right) \Psi_{q r},
\end{aligned}
$$

where $R_{s}$ - stator inductance, $i_{q s 1}, i_{q s 2}$ - stator $q$ axis current components, $i_{d s 1}, i_{d s 2}-$ stator $d$ axis current components, $\Psi_{q s 1}, \Psi_{q s 2}$ - stator $q$ axis flux linkage components, $\Psi_{d s 1}, \Psi_{d s 2}$ - stator $d$ axis flux linkage components, $R_{r}$ - rotor inductance, $i_{q r}$ - rotor $q$ axis current component, $i_{d r}$ - rotor $d$ axis current component, $\Psi_{q r}$ - rotor $q$ axis flux linkage component, $\Psi_{d r}$ - rotor $d$ axis flux linkage component, $s$ - Laplace operator, $\omega_{e}$-speed of rotating magnetic field, $\omega_{r}$-speed of rotor.

The flux linkages are expressed as:

$$
\begin{aligned}
& \Psi_{q s 1}=L_{l s} i_{q s 1}+L_{l m}\left(i_{q s 1}+i_{q s 2}\right)+L_{m}\left(i_{q s 1}+i_{q s 2}+i_{q r}\right), \\
& \Psi_{d s 1}=L_{l s} i_{d s 1}+L_{l m}\left(i_{d s 1}+i_{d s 2}\right)+L_{m}\left(i_{d s 1}+i_{d s 2}+i_{d r}\right), \\
& \Psi_{q s 2}=L_{l s} i_{q s 2}+L_{l m}\left(i_{q s 1}+i_{q s 2}\right)+L_{m}\left(i_{q s 1}+i_{q s 2}+i_{q r}\right), \\
& \Psi_{d s 2}=L_{l s} i_{d s 2}+L_{l m}\left(i_{d s 1}+i_{d s 2}\right)+L_{m}\left(i_{d s 1}+i_{d s 2}+i_{d r}\right), \\
& \Psi_{q r}=L_{l r} i_{q r}+L_{m}\left(i_{q s 1}+i_{q s 2}+i_{q r}\right), \\
& \Psi_{d r}=L_{l r} i_{d r}+L_{m}\left(i_{d s 1}+i_{d s 2}+i_{d r}\right),
\end{aligned}
$$


where $L_{l s}$ - stator leakage inductance, $L_{m}$ - magnetizing inductance, $L_{l m}$ - stator mutual leakage inductance, $L_{l r}$ - rotor leakage inductance.

The voltage and flux linkage equations corresponds the equivalent circuits, shown in Fig. S.1 and Fig. S.2.

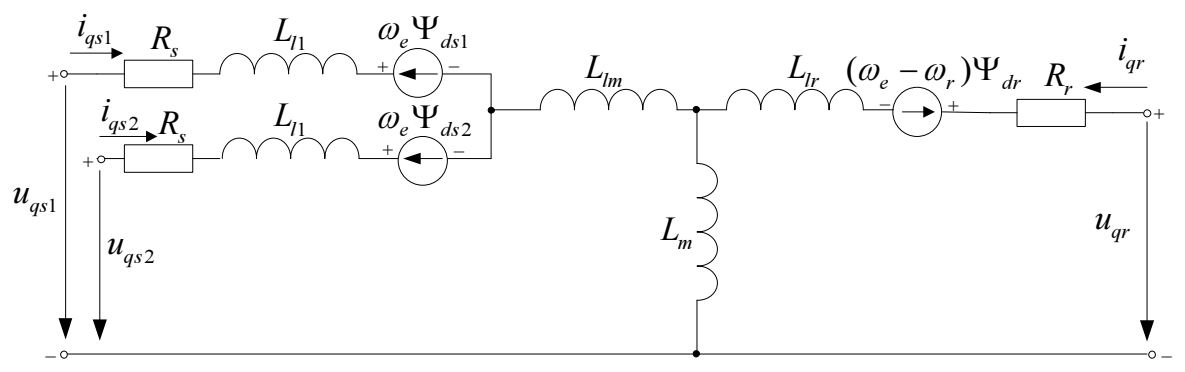

Fig. S.1. Dynamic equivalent per phase circuit $d-q$ of induction motor, $q$ circuit frame as:

The electromagnetic torque can be expressed in the synchronous $d-q$ reference

$$
M_{e}=\frac{3}{2}\left(\frac{P}{2}\right)\left(\frac{L_{m}}{L_{r}}\right)\left[\Psi_{d r}\left(i_{q s 1}+i_{q s 2}\right)-\Psi_{q r}\left(i_{d s 1}+i_{d s 2}\right)\right],
$$

where $P$ - number of pole, $L_{r}$ - rotor inductance.

The equation of drive movement is written as:

$$
\frac{d \omega_{e}}{d t}=\frac{1}{J}\left(M_{e}-M_{s t}\right)
$$

where $J$ - rotor inertia, $M_{e}$ - electromagnetic torque developed by motor, $M_{s t}-$ load torque.

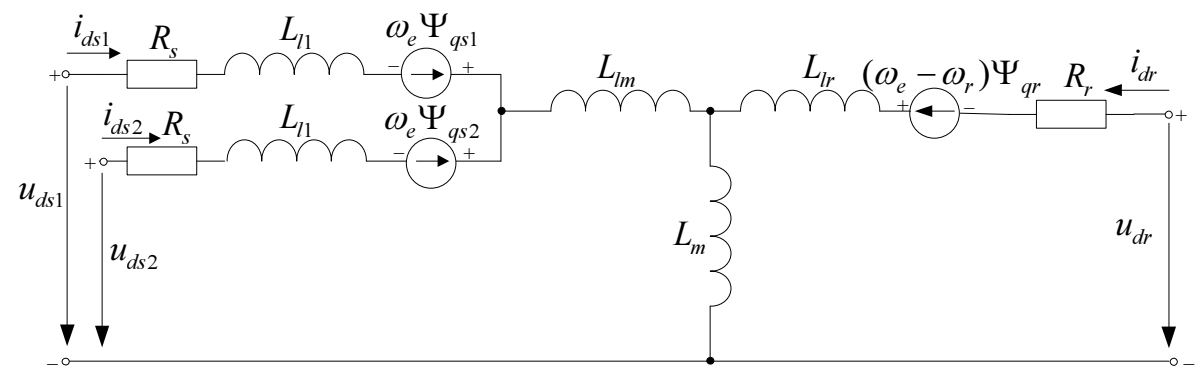

Fig. S.2. Dynamic equivalent per phase circuit $d-q$ of induction motor, $d$ circuit 


\section{Methods to develop six phase motor model}

According to (S.1) and (S.2) formulas following current equations in synchronous reference frame are obtained:

$$
\begin{aligned}
& i_{q s 1}=\frac{1}{s} \frac{1}{\left(L_{l s}+L_{l m}+L_{m}\right)}\left\{u_{q s 1}-R_{s} i_{q s 1}-s\left(L_{l m}+L_{m}\right) i_{q s 2}-s L_{m} i_{q r}-\right. \\
& \left.-\omega_{e}\left[\left(L_{l s}+L_{l m}+L_{m}\right) i_{d s 1}+\left(L_{l m}+L_{m}\right) i_{d s 2}+L_{m} i_{d r}\right]\right\}, \\
& i_{q s 2}=\frac{1}{s} \frac{1}{\left(L_{l s}+L_{l m}+L_{m}\right)}\left\{u_{q s 2}-R_{s} i_{q s 2}-s\left(L_{l m}+L_{m}\right) i_{q s 1}-s L_{m} i_{q r}-\right. \\
& \left.-\omega_{e}\left[\left(L_{l s}+L_{l m}+L_{m}\right) i_{d s 2}+\left(L_{l m}+L_{m}\right) i_{d s 1}+L_{m} i_{d r}\right]\right\}, \\
& i_{d s 1}=\frac{1}{s} \frac{1}{\left(L_{l s}+L_{l m}+L_{m}\right)}\left\{u_{d s 1}-R_{s} i_{d s 1}-s\left(L_{l m}+L_{m}\right) i_{d s 2}-\right. \\
& \left.-s L_{m} i_{d r}+\omega_{e}\left[\left(L_{l s}+L_{l m}+L_{m}\right) i_{q s 1}+\left(L_{l m}+L_{m}\right) i_{q s 2}+L_{m} i_{q r}\right]\right\}, \\
& i_{d s 2}=\frac{1}{s} \frac{1}{\left(L_{l s}+L_{l m}+L_{m}\right)}\left\{u_{d s 2}-R_{s} i_{d s 2}-s\left(L_{l m}+L_{m}\right) i_{d s 1}-\right. \\
& \left.-s L_{m} i_{d r}+\omega_{e}\left[\left(L_{l s}+L_{l m}+L_{m}\right) i_{q s 2}+\left(L_{l m}+L_{m}\right) i_{q s 1}+L_{m} i_{q r}\right]\right\}, \\
& i_{q r}=\frac{1}{s} \frac{1}{L_{l r}+L_{m}}\left\{u_{q r}-R_{r} i_{q r}-s L_{m}\left(i_{q s 1}+i_{q s 2}\right)-\right. \\
& \left.-\left(\omega_{e}-\omega_{r}\right)\left[\left(L_{l r}+L_{m}\right) i_{d r}+L_{m}\left(i_{d s 1}+i_{d s 2}\right)\right]\right\}, \\
& \left.i_{d r}=\frac{1}{s} \frac{1}{L_{l r}+L_{m}}\left\{\omega_{r}\right)\left[\left(L_{l r}+L_{m}\right) i_{q r}+L_{m}\left(i_{q s 1}+i_{q s 2}\right)\right]\right\} .
\end{aligned}
$$

The six phase induction motor Simulink ${ }^{\mathbb{R}}$ model is developed according to (S.3), (S.4) and (S.5) expressions. It consists of stator, rotor and torque computational models. Computational stator model is shown in the Fig. S.3. Computational rotor and torque models are shown respectively in the Fig. S.4 and Fig. S.5.

The six phase induction motor model for dynamic characteristic investigation can be used. Different voltage values in computational stator model blocks step 1 and step 2 can be selected. Reference voltage and speed ratio can be settled in this motor model using voltage and speed connections. Different loads can be connected to the rotor shaft at investigating of motor transients.

The Simulink ${ }^{\circledR}$ motor model is compatible with all motors control models made in this program. The six phase Simulink ${ }^{\mathbb{R}}$ motor model can be used in real system to change a part of it for faults examination. 


\section{Simulation and experimental results of six phase induction motor investigation}

Six phase induction motors are not produced. The experimental model should be designed starting from windings layout.

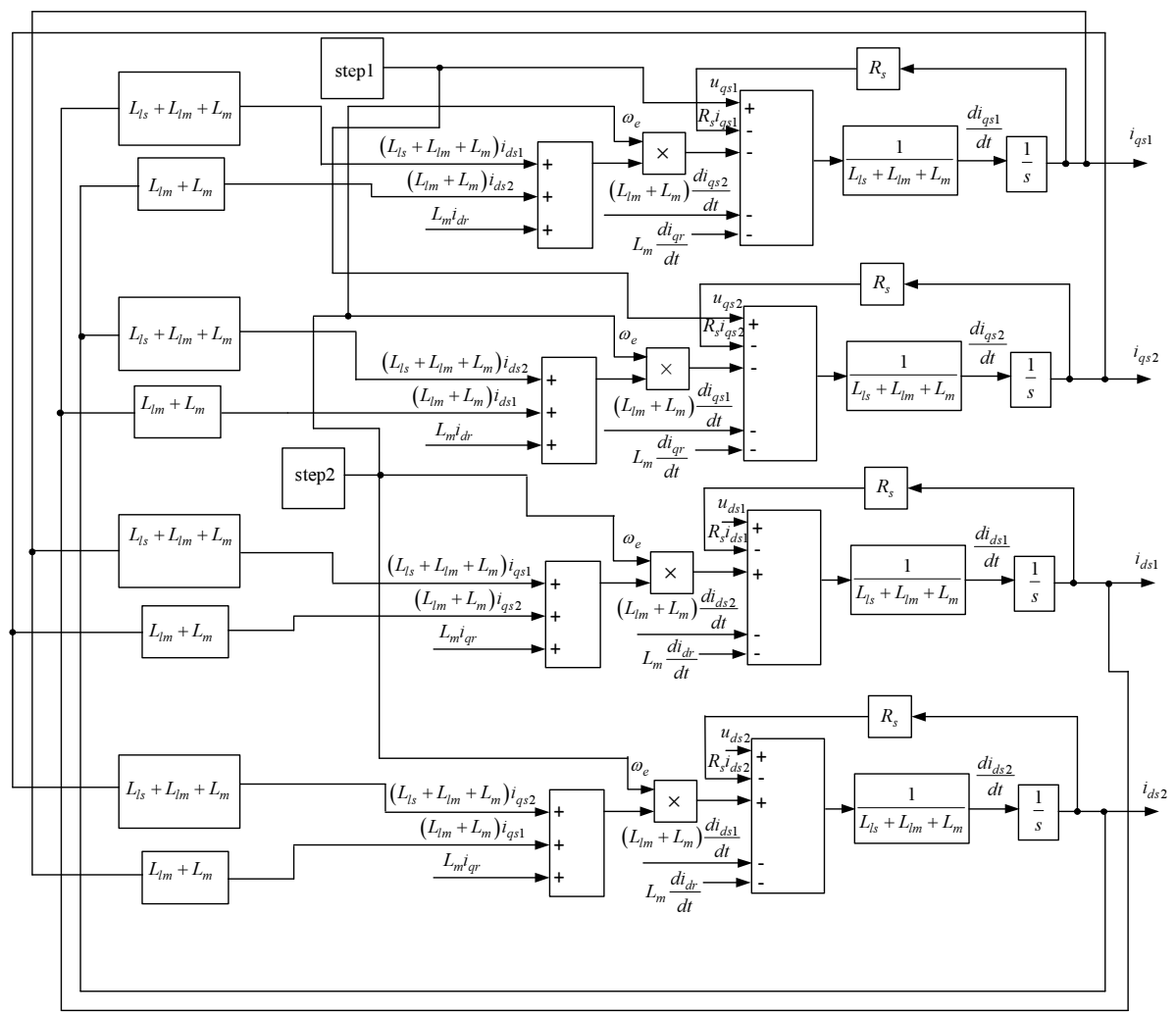

Fig. S.3. Computational stator model of six phase induction motor

Double layer windings have many advantages over single layer windings: easier to manufacture and lower cost of coils, fractional slot can be used, chorded winding is possible, lower leakage reactance and therefore, better performance of the machine. Parameters of stator winding are: total number of slots $S=48$, number of poles $2 P=8$, number of phase $m=6$, pole pitch $\tau=6$, slot angular pitch $\alpha=\frac{\pi}{6}=30^{\circ}$, number of slots per pole per phase $q=1$, coil pitch $y=5$, phase spread $\sigma_{1}=\frac{\pi}{5}=30^{\circ}$, angle 
between stator current phasors is $60^{\circ}$. Elaborated connection scheme of winding sections is presented in Fig. S.6.

Concentrated double layer short pitch coil six phase winding and magnetomotive force is presented in Fig. S.7.

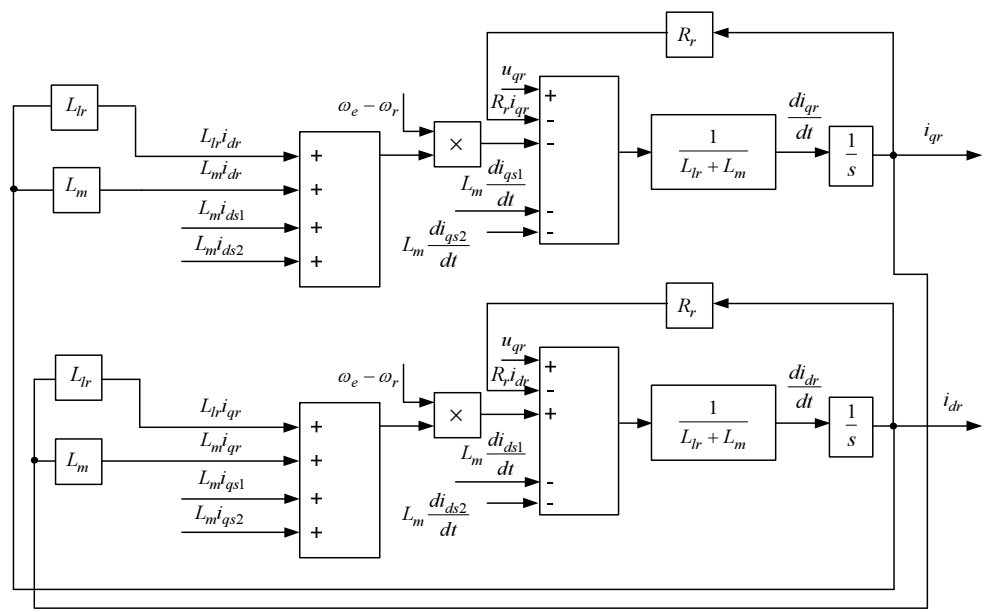

Fig. S.4. Computational rotor model of six phase induction motor

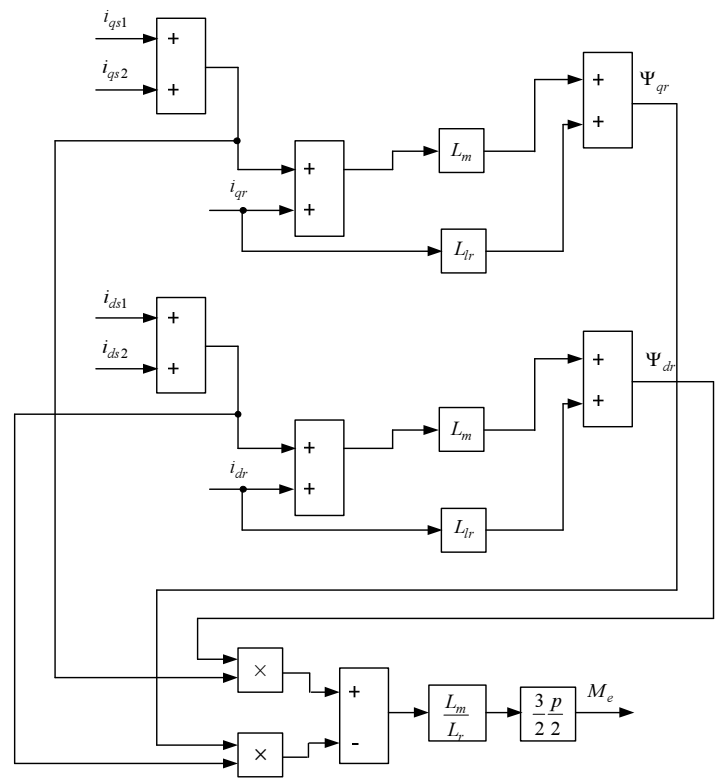

Fig. S.5. Computational model of six phase induction motor torque 
Parameters of stator full pitch coil winding are equal to that of the first one, only coil pitch $y=6$ and phase spread $\sigma_{1}=\frac{\pi}{6}=30^{\circ}$. Concentrated double layer full pitch coil six phase winding and magnetomotive force is presented in Fig. S.8.

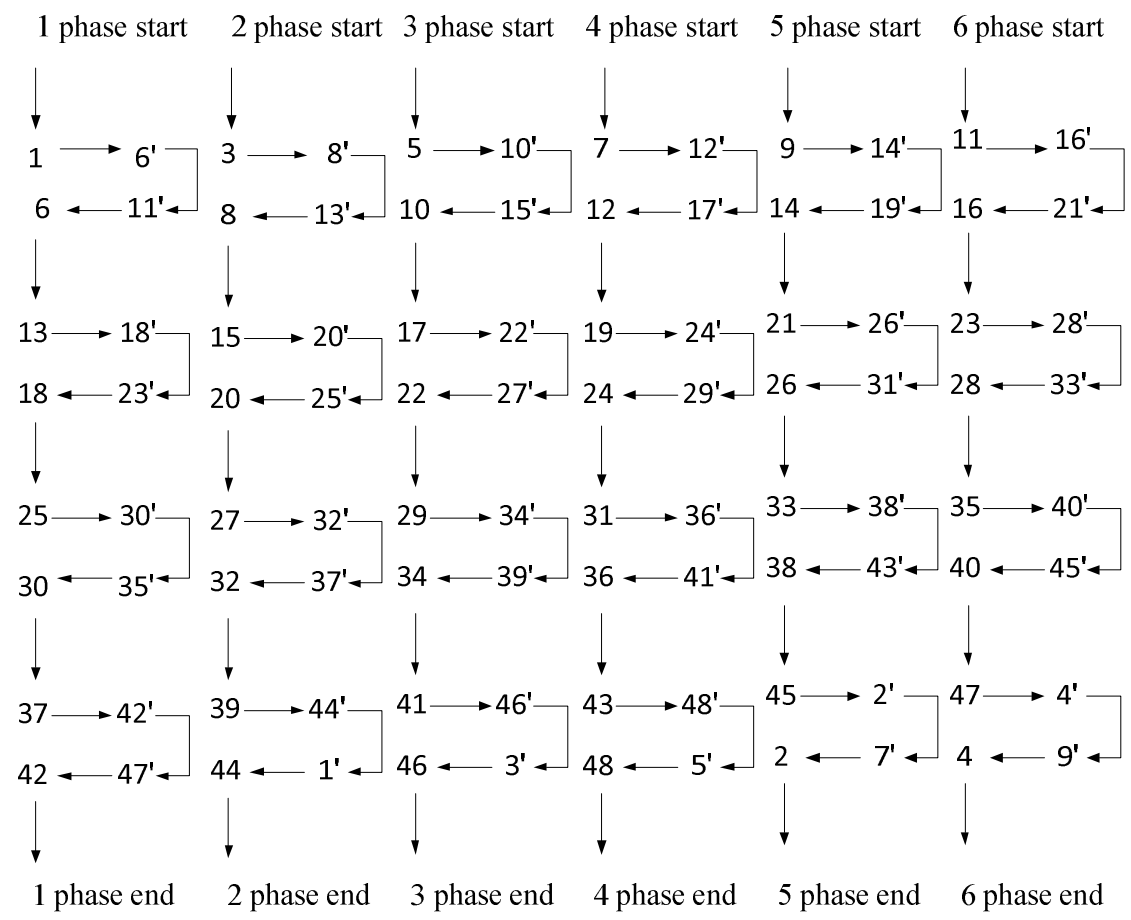

Fig. S.6. Concentrated double layer short pitch coil six phase winding connection scheme of sections

Analysis of the considered first type of winding indicates, that during one pole pitch the relative magnetomotive force $F_{1}(\varphi)$ has the shape, shown in Fig. S.9.

Space harmonic spectrum of each winding magnetomotive force can be obtained on the base of Fourier series. The Fourier transform coefficients of the function $F_{1}(\varphi)$, shown in Fig. S.9 are calculated in this way:

$$
\begin{aligned}
& b_{1, k}=\frac{2 A_{1}}{\pi} \int_{\pi / 6}^{5 \pi / 6} \sin k \phi d \phi+\frac{2 A_{2}}{\pi} \int_{\pi / 3}^{2 \pi / 3} \sin k \phi d \phi= \\
& =\frac{4}{\pi k}\left(A_{1} \sin \frac{\pi k}{3}+A_{2} \sin \frac{\pi k}{6}\right) \sin \frac{\pi k}{2},
\end{aligned}
$$

where $A_{1}=1 / 3$ and $A_{2}=2 / 3$ are amplitudes of relative magnetomotive force components. 

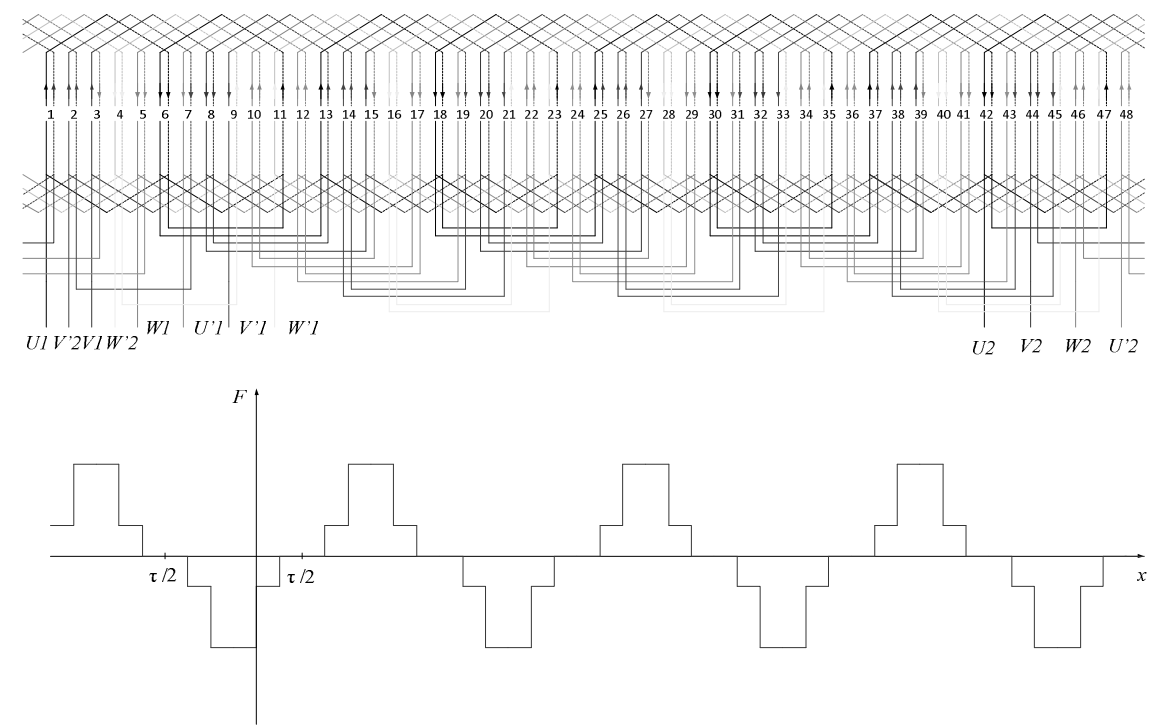

Fig. S.7. Connection of concentrated double layer short pitch coil six phase winding section and space distribution of magnetomotive force
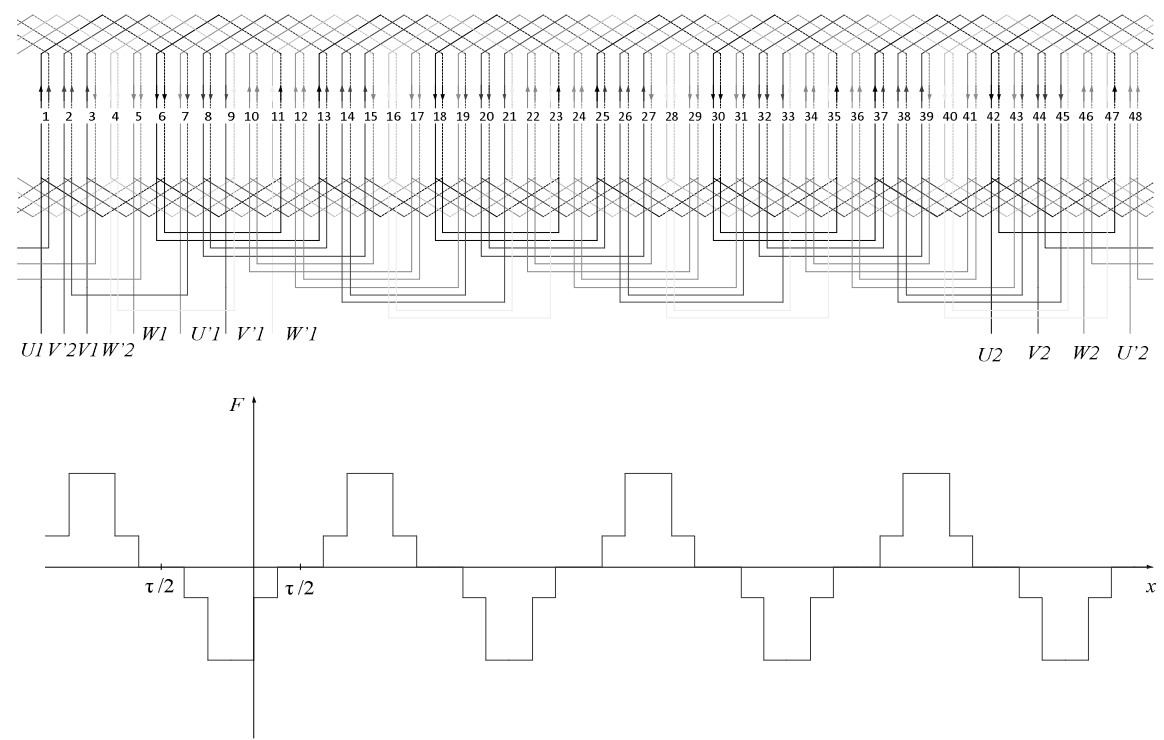

Fig. S.8. Connection of concentrated double layer full pitch coil six phase winding section and space distribution of magnetomotive force

According to (S.6) the Fourier series coefficients were calculated. The Fourier series is expressed as: 


$$
F_{1, \Sigma K}=\sum_{k=0}^{K} b_{1, k} \sin k \phi .
$$

Fourier series of function $F_{1}(\varphi)$ at $k=0-50$ is presented in Fig. S.9 and denoted as $F_{1, \Sigma 50}(\varphi), \varphi=\sigma_{1} N, N=0-5$.

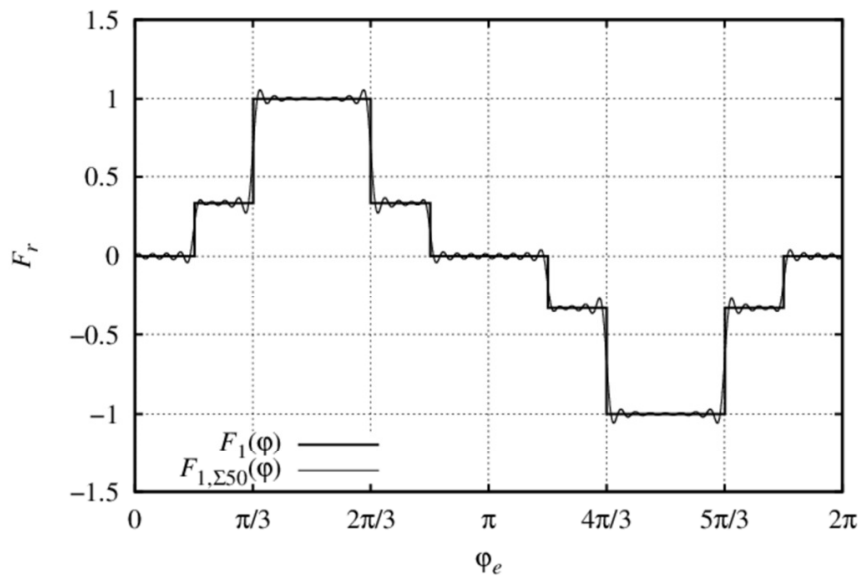

Fig. S.9. Relative magnetomotive force $F_{1}(\varphi)$ ant its approximation by Fourier series $F_{1, \Sigma 50}(\varphi)$

Analysis of the second type winding shows, that relative magnetomotive force $F_{2}(\varphi)$ in the one pole pitch displacement varies in the way, shown in Fig. S.10.

Fourier series coefficients of function $F_{2}(\varphi)$ are calculated in the form:

$$
\begin{aligned}
b_{2, k} & =\frac{2 A_{1}}{\pi} \int_{\pi / 4}^{3 \pi / 4} \sin k \phi d \phi+\frac{2 A_{2}}{\pi} \int_{5 \pi / 12}^{7 \pi / 12} \sin k \phi d \phi= \\
& =\frac{4}{\pi k}\left(A_{1} \sin \frac{\pi k}{4}+A_{2} \sin \frac{\pi k}{12}\right) \sin \frac{\pi k}{2},
\end{aligned}
$$

where $A_{1}=1 / 2$ and $A_{2}=1 / 2$ are amplitudes of relative magnetomotive force components.

In accordance with expression (S.8) the series can be rewritten in the form:

$$
F_{2, \Sigma K}=\sum_{k=0}^{K} b_{2, k} \sin k \phi \text {. }
$$

Fourier series of function $F_{2}(\varphi)$ at $k=0-50$ is presented in Fig. S. 10 and denoted as $F_{2, \Sigma 50}(\varphi)$.

Analysis of magnetomotive forces gives information about higher harmonics, appearing in the air gap. Comparing the amplitude $b_{2, k}$ of $k$-th harmonic magnetomotive force $F_{2}(\varphi)$ with amplitude $b_{1, k}$ of $k$-th harmonic magnetomotive force $F_{1}(\varphi)$, the difference between those is calculated and expressed in percent as:

$$
\delta_{k}=\frac{\left|b_{2, k}\right|-\left|b_{1, k}\right|}{b_{1,1}} 100 \% \text {. }
$$




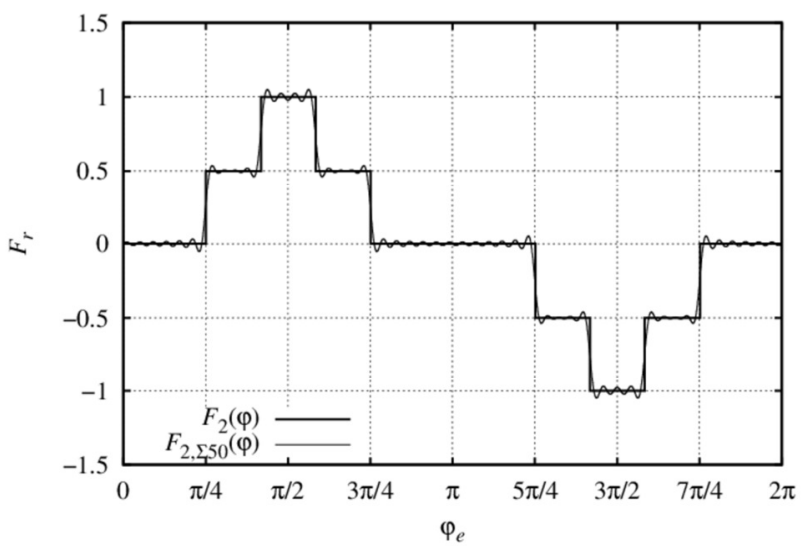

Fig. S.10. Relative magnetomotive force $F_{2}(\varphi)$ ant its approximation by Fourier series $F_{2,550}(\varphi)$

Values, calculated according to expression (S.10) are presented in Fig. S.11. It indicates, that the short pitch coil six phase winding has the first harmonic significantly greater, by $22 \%$. Analysis shows, that the first harmonic of this winding approximately is equal to 0.8 and that of the full pitch coil six phase winding is smaller - reaches 0.6 . So from the point of view of the first harmonic the motor with the short pitch coil six phase winding will have higher efficiency.

Analysis shows, that even harmonics have the same amplitude. According to expression (S.6) and (S.8), they are equal to zero.

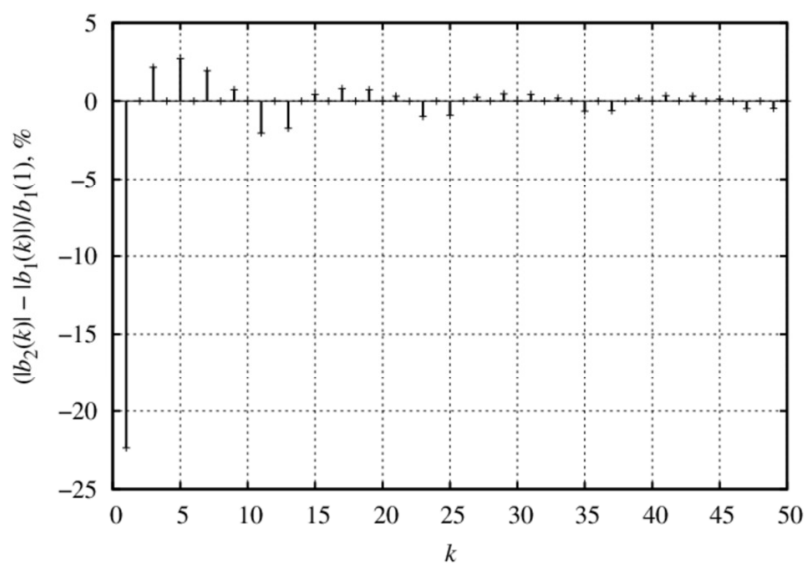

Fig. S.11. Dependence of harmonic amplitude difference $\delta_{k}$ from harmonic number $k$

Fig. S.11 shows, that difference of higher odd harmonics $\left|b_{2,1}\right|-\left|b_{1,1}\right|>0$. That indicates the odd higher harmonics of second winding having greater amplitude. While the higher harmonics increase torque oscillations and heat loss, it is possible to state, that the first winding has greater efficiency. 
So research indicated that according to the harmonic spectrum, the first winding has greater efficiency than second one.

The concentrated double layer short pitch coil six phase winding for experimental motor was used. To verify adequacy of six phase induction motor simulation results to experimental, test stand was made. The structure of stand is shown in Fig. S.12. It consists of: 1 - autotransformers, 2 - six phase transformer, 3 - six phase induction motor, 4 - torque sensor, 5 - clutch, 6 - generator, 7 - converter from frequency to voltage, 8 - oscilloscope, 9 - DC supply.

Experimental and simulation torque characteristics of six phase induction motor at $200 \mathrm{~V}$ supply is presented in Fig. S.13. Here and in all next figures 1 - shows theoretical results and 2 - shows practical ones. Fig. S.14 shows speed transients at the same supply voltage.

According to Fig. S.13 and Fig. S.14 starting transients at $200 \mathrm{~V}$ supply voltage lasts 1.65 second in simulation mode and 1.7 second in experimental mode. After that induction motor rotor speed reaches steady state value equal to $78 \mathrm{rad} / \mathrm{s}$ in both cases and torque reaches $2 \mathrm{~N} \cdot \mathrm{m}$, because of rotor connection with DC generator. The greatest value of torque in simulation and experimental modes respectively are $4.8 \mathrm{~N} \cdot \mathrm{m}$ and 5 $\mathrm{N} \cdot \mathrm{m}$. It is evident that six phase induction motor model at $200 \mathrm{~V}$ supply voltage simulates experimental settling time with 3\% error and determinates maximal torque value with $4 \%$ error. Model determinates exact practical steady state rotor speed value.

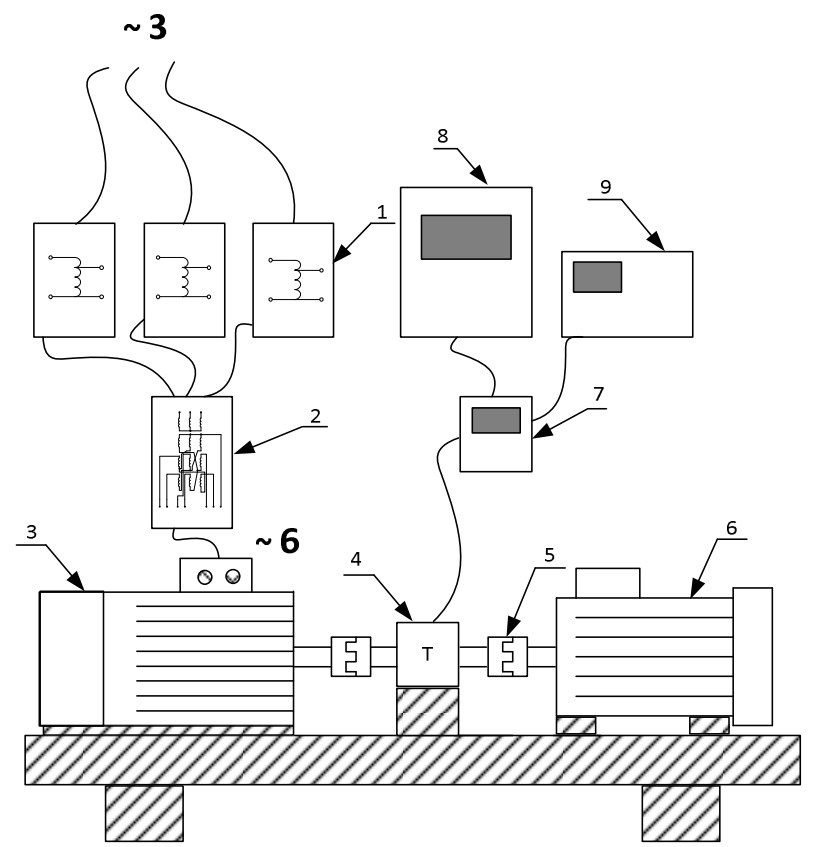

Fig. S.12. Structure of the six phase induction motor experimental stand 
Experimental and simulation torque characteristics of six phase induction motor at $225 \mathrm{~V}$ supply is presented in Fig. S.15. Fig. S.16 shows speed transients at the same supply voltage.

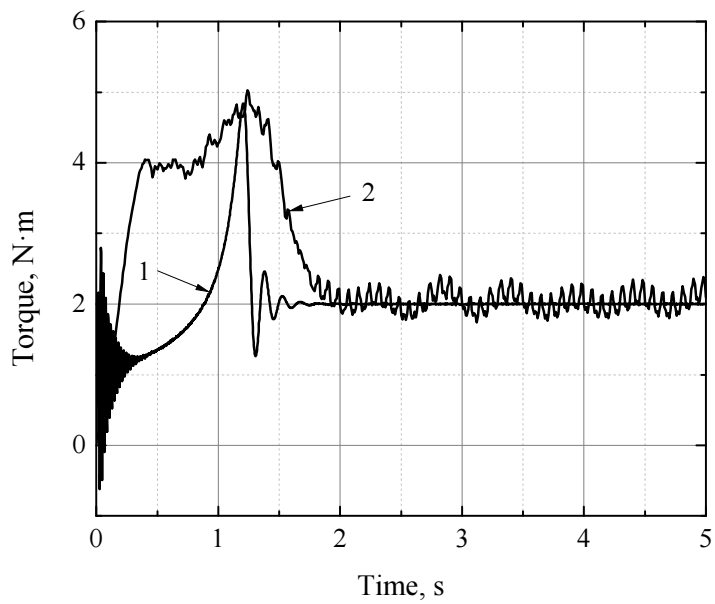

Fig. S.13. Torque characteristic of six phase induction motor, at $200 \mathrm{~V}$ supply voltage

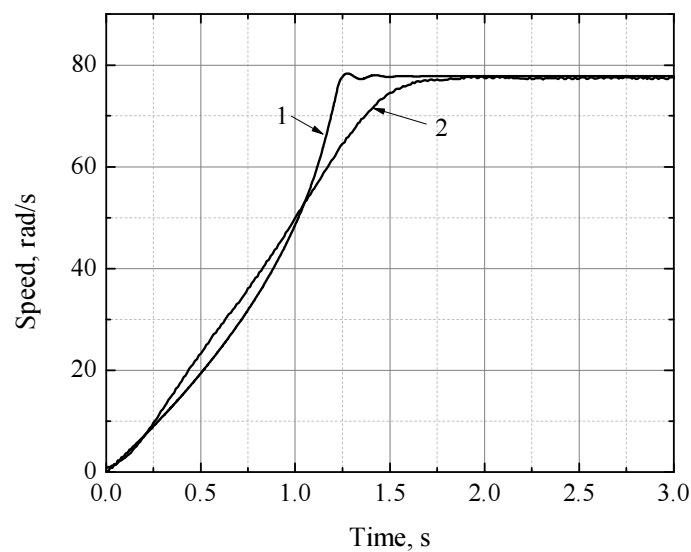

Fig. S.14. Speed characteristic of six phase induction motor, at $200 \mathrm{~V}$ supply voltage

According to Fig. S.15 and Fig. S.16 starting transients at $225 \mathrm{~V}$ supply voltage lasts 1.3 second in simulation mode and 1.25 second in experimental mode. After that induction motor rotor speed reaches steady state value equal to $78 \mathrm{rad} / \mathrm{s}$ in both cases and torque reaches $2.2 \mathrm{~N} \cdot \mathrm{m}$, because of rotor connection with DC generator and ventilator effects. The greatest value of torque in simulation and experimental modes are $6 \mathrm{~N} \cdot \mathrm{m}$. 
According to that, six phase induction motor model at $225 \mathrm{~V}$ supply voltage simulates experimental settling time with $4 \%$ error and determinates exact maximal torque and steady state rotor speed values.

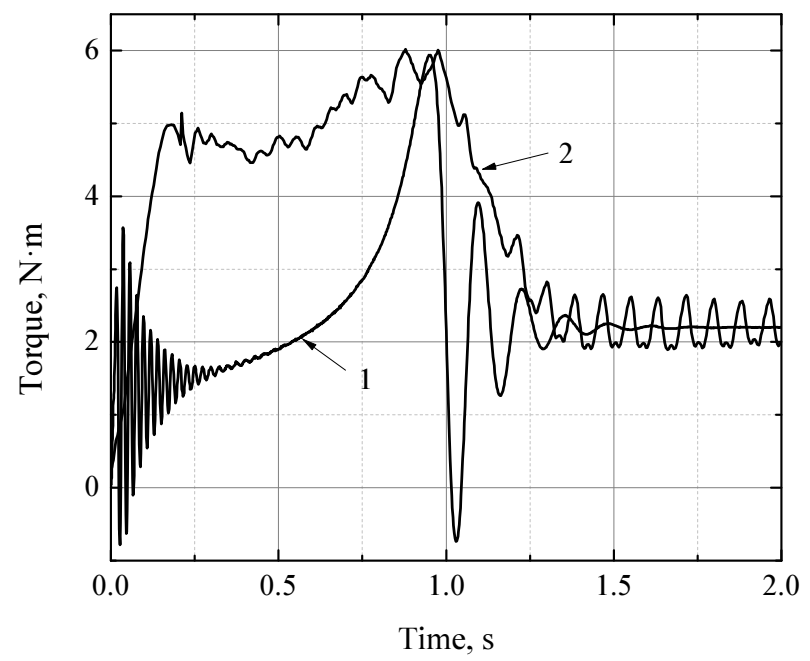

Fig. S.15. Torque characteristic of six phase induction motor, at $200 \mathrm{~V}$ supply voltage

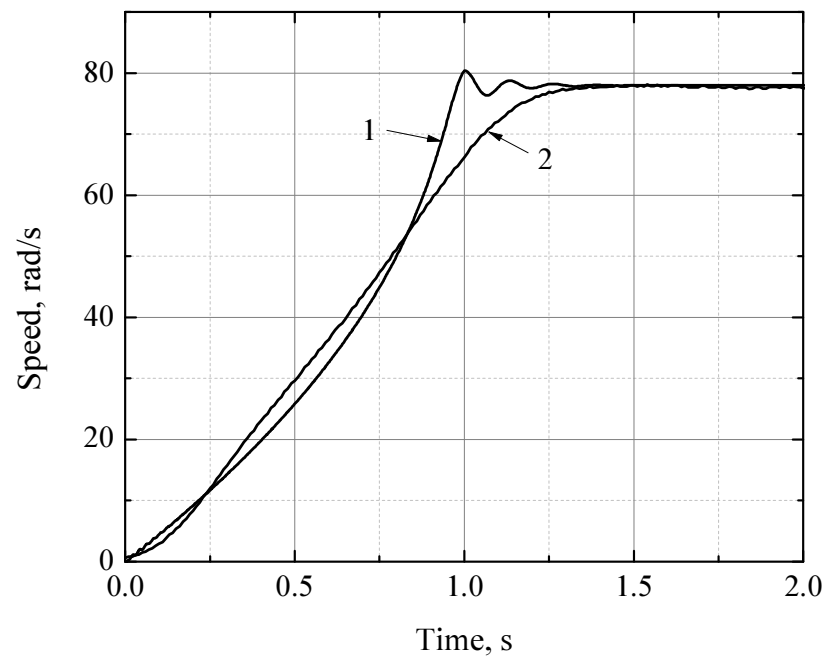

Fig. S.16. Speed characteristic of six phase induction motor, at $200 \mathrm{~V}$ supply voltage 


\section{General conclusions}

1. Proposed six phase induction motor Matlab ${ }^{\mathbb{R}}$ Simulink ${ }^{\mathbb{R}}$ model according to stator and rotor currents for six phase induction motor starting transients with different supply voltage and load can be used. This model can be applied for controlled induction drives development. Six phase induction motor model can be used in rapid prototyping to verify system operation.

2. New concentrated double layer short pitch coil six phase winding and new concentrated double layer full pitch coil six phase winding were designed. The efficiency were compared and greater efficiency concentrated double layer short pitch coil winding for experimental six phase induction motor was used. After experimental test was found that six phase induction motor slip is equal to 0.01 and rotor steady state speed $78 \mathrm{rad} / \mathrm{s}$ is close to electromagnetic field synchronous rotation speed $78.5 \mathrm{rad} / \mathrm{s}$.

3. Compared dynamic characteristics of six phase induction motor starting at different supply voltages. Experimental results shows that six phase induction motor Simulink $^{\circledR}$ model simulates experimental settling time with $4 \%$ error, determinates maximal torque value with $4 \%$ error and shows close steady state rotor speed value. According to assumption made for mathematical model results of simulation do not corresponded all experimental values.

4. Simulation results of six phase induction motor shows that the maximal torque value increases and transients time decreases when supply voltage and load is increased. Simulation and experimental results shows the same appearance at six phase induction motor starting. 


\section{Priedai $^{*}$}

A priedas. Bendraautorių sutikimai teikti publikacijų medžiagą disertacijoje

B priedas. Autoriaus mokslinių publikacijų disertacijos tema kopijos

\footnotetext{
* Priedai pateikiami pridètame kompaktiniame diske
} 

Benas KUNDROTAS

ŠEŠIAFAZIŲ ASINCHRONINIỤ VARIKLIŲ PEREINAMŲJŲ VYKSMŲ TYRIMAS

Daktaro disertacija

Technologijos mokslai, elektros ir elektronikos inžinerija (01T)

\section{Benas KUNDROTAS}

RESEARCH ON TRANSIENT PROCESSES OF SIX PHASE INDUCTION MOTORS

Doctoral Dissertation

Technological Sciences,

Electrical and Electronic Engineering (01T)

201405 05. 11 sp. I. Tiražas 20 egz.

Vilniaus Gedimino technikos universiteto

leidykla "Technika“,

Saulètekio al. 11, 10223 Vilnius,

http://leidykla.vgtu.lt

Spausdino UAB „Baltijos kopija“,

Kareivių g. 13B, 09109 Vilnius 